\title{
Spain: Basel Core Principles for Effective Banking Supervision- Detailed Assessment of Compliance Report
}

This paper was prepared based on the information available at the time it was completed on May

2012. The views expressed in this document are those of the staff team and do not necessarily reflect the views of the government of Spain or the Executive Board of the IMF.

The policy of publication of staff reports and other documents by the IMF allows for the deletion of market-sensitive information.

Copies of this report are available to the public from

International Monetary Fund • Publication Services

700 19th Street, N.W. • Washington, D.C. 20431

Telephone: (202) 623-7430 • Telefax: (202) 623-7201

E-mail: publications@imf.org •Internet: http://www.imf.org

\section{International Monetary Fund \\ Washington, D.C.}


FINANCIAL SECTOR ASSESSMENT PROGRAM UPDATE

\section{SPAIN}

BASEL CORE PRINCIPLES FOR EFFECTIVE BANKING

SUPERVISION

DETAILED ASSESSMENT OF COMPLIANCE

MAY 2012 
Glossary 3

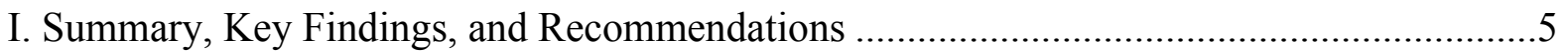

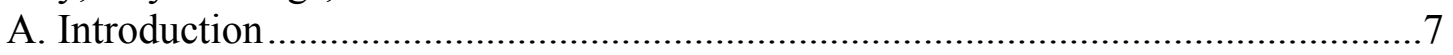

B. Information and Methodology Used for Assessment.............................................7

C. Institutional and Macroeconomic Setting and Market Structure-Overview............9

D. Preconditions for Effective Banking Supervision..................................................10

E. Main Findings.................................................................................................13

Objectives, independence, powers, transparency, and cooperation (CP 1) .....13

Licensing and structure (CPs 2-5) ................................................................. 14

Prudential regulation and requirements (CPs 6-18) ……................................14

Methods of ongoing banking supervision (CPs 19-21) ..................................15

Accounting and disclosure (CP 22) ..............................................................16

Corrective and remedial powers of supervisors (CP 23) .................................16

Consolidated and cross-border banking supervision (CPs 24-25) ...................16

F. Recommended Actions and Authorities' Response ..................................................31

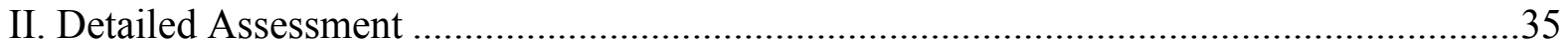

Tables

1A. Summary Compliance with the Basel Core Principles-ROSCs ......................................17

1B. Summary Compliance with the Basel Core Principles-Detailed Assessments ...............23

2. Recommended Action Plan to Improve Compliance with the Basel Core Principles .......31

3. Detailed Assessment of Compliance with the Basel Core Principles..................................35 


\section{GLOSSARY}

AC

AMA

AML/CFT

BCBS

BCP

BdE

BL

CAR

CARcp

CBE

CE

CEBS

CESFI

CCAA

CIR

CNMV

CP

CRD

DGSFP

EBA

EC

ELA

EU

FIU

FGD

FROB

FSAP

IAC

IAIS

ICAAP

ICAC

ICP

IFRS

IOSCO

IRB

IRBE

IRR

LABE

LC

LDI

ManCos

MNC

$\mathrm{MO}$

$\mathrm{MoE}$
Additional Criteria

Advanced Measurement Approach (operational risk)

Anti-money Laundering and Combating the Financing of Terrorism

Basel Committee on Banking Supervision

Basel Core Principles for Effective Banking Supervision

Banco de España

Banking Law of 31 December 1946

Capital Adequacy Ratio

Capital adequacy ratio based on capital principal

Circular de Banco de España

Spanish Constitution

Committee of European Banking Supervisors

Committee for Financial Stability

Autonomous Communities

Central de Información de Riesgos

National Markets and Securities Commission

Core Principle

Capital Requirements Directive

General Directorate of Insurance and Pension Funds

European Banking Authority

Essential Criteria

Emergency Liquidity Assistance

European Union

Financial Intelligence Unit

Fondo de Garantía de Depósitos

Fondo de Reestructuración Ordenada Bancaria

Financial Sector Assessment Program

Informe de Autoevaluación de Capital

International Association of Insurance Supervisors

Internal Capital Adequacy Assessment Program

Instituto de Contabilidad y Auditoría de Cuentas

Insurance Core Principles

International Financial Reporting Standards

International Organization of Securities Commissions

Internal Ratings Based Approach

Internal Rules of BdE

Interest Rate Risk

Law 13/1994 on the Autonomy of BdE

Largely Compliant

Law 26/1988, on Discipline and intervention of credit institutions

Mandatory Convertible Instruments

Materially Non Compliant

Ministerial Order

Ministry of Economy 


$\begin{array}{ll}\text { MoU } & \text { Memorandum of Understanding } \\ \text { OCC } & \text { Office of the Comptroller of the Currency } \\ \text { RD } & \text { Royal Decree (Real Decreto) } \\ \text { RDL } & \text { Royal Decree Law (Real Decreto Ley) } \\ \text { RWA } & \text { Risk Weighted Assets } \\ \text { SABER } & \text { Supervision of the Banking Activity By Risk Approach } \\ \text { SEPBLAC } & \text { Servicio Ejecutivo de la Comisión de Prevención del Blanqueo de } \\ & \text { Capitales } \\ \text { SIA } & \text { System of Information on Borrowers } \\ \text { SPV } & \text { Special Purpose Vehicle }\end{array}$




\section{SUMMARY, KEY FINDINGS, AND RECOMMENDATIONS}

\section{Significant changes have occurred in Spain since the last Financial Sector} Assessment Program (FSAP). The most serious has been the deterioration of the economy and the real estate sector leading to a major decline in land values and the financial condition of developers impacting loan quality. The current crisis impacted the savings banks more severely due to their high concentrations in loans to finance land development and construction and highlighted a serious weakness in their risk management, leading to a complete restructuring of the sector and converting their vast majority into commercial banks. The commercial banks, with more diversified loan portfolios and bolstered by high levels of loan loss provisions, fared better through the initial phase but are under increasing pressure as provisioning and capital requirements continue to increase. On the regulatory side, the period was framed by the implementation of Basel II.

\section{The core supervisory process at the Banco de España (BdE) is strong and is} supported by qualified staff and an experienced cadre of inspectors, but there were areas of concern identified and discussed in the mission. The authorities have made progress in addressing the recommendations of the 2006 FSAP as regulatory capital and loan-loss provisioning requirements for real estate exposures have been tightened and further guidance on best practices for lending in this area has been provided. The authorities have also implemented measures to reduce incentives for equity investments in nonfinancial companies by banks and to manage related conflicts of interest; introduced reforms to strengthen corporate governance and the ability to raise capital from external sources for savings banks; enhanced coordination and cooperation between financial sector regulators; adopted additional requirements on internal controls, investment, and adequate verification of the risk management processes of insurers; and improved the functioning of securities settlement systems. However, in spite of the high technical quality of the supervisory process, the closure of the supervisory work does not seem to be sufficiently timely or effective for bank resolution. There are areas requiring attention such as timeliness of remedial action, operational independence concerning issuance of regulations and enforcement, and oversight of concentration risk and related party transactions. Some of these issues are also addressed in the crisis management technical note that is part of this FSAP.

\section{A review of examples of inspection activities and reports revealed the thoroughness of the supervisory process and the identification of key risks and their communication to bank management, however, the process for requiring corrective action is lengthy and corrective action tools were not timely applied. The BdE identified at a very early stage the need for provisions and recommended corrective action, but the formal decisions were only adopted after following the deliberate BdE process and not fully employing all its available enforcement tools as it focused on broader systemic responses. This resulted in the continued accumulation of problems and losses as the bank or savings}


bank continued operating without major restrictions during the process. Discussions with the authorities provided context to their process and the timeliness issue. According to the authorities, the deterioration in the economy was more protracted than initially anticipated as was the deterioration in the financing of land and real estate development. As weak institutions were identified and it became apparent that a broader fix would be required rather than dealing with individual institutions, the BdE started to encourage mergers and did not close banks waiting for a market solution to achieve the lower cost option. ${ }^{1}$ As the BdE reviewed the broader solution options, the use of enforcement tools to protect bank capital and avoid asset dissipation was not widely used. For example, implementing cease and desist orders to limit or eliminate dividends, putting in place strict review requirements before continuing to fund existing projects and severely curtailing new projects. Further, these decisions took into account the information available at the time, the legal framework currently in force, the cost to the public purse, and the implications for financial stability. BdE was of the view that since the troubled institutions had significantly curtailed lending to the troubled sectors; the level of bad assets would not increase.

4. A review of the legal framework identified areas where the BdE authority can be increased to expedite corrective action. The BdE lacks authority to issue prudential regulations, except in areas specifically delegated by law or the Ministry of Economy (MoE). Having the authority to issue prudential regulations would enable the BdE to address at an earlier stage developments of a systemic nature. In addition, enforcement action is shared with the MoE, with the BdE having to send to the Ministry the more grave issues for enforcement. Having a flexible enforcement regime enables the supervisor to quickly adjust a course of action should original assumptions prove incorrect, and a more intense use of sanctions should work as deterrent to imprudent risk management.

\section{The regulatory framework and oversight over concentration risk and related party transactions were not sufficient to address significant build-up of weaknesses in} the system, some of them derived from the peculiar corporate governance structure for savings banks. In the case of savings banks, the issue may have been aggravated by the division of responsibilities with the Autonomous Communities (CCAA). ${ }^{2}$ Although the number of savings banks has been drastically reduced and their banking business transferred to commercial banks, the shareholder and corporate structure of the new banks is complex and the BdE will need to apply particular attention to make sure deficiencies in the previously existing structures do not contaminate the banking organizations.

\footnotetext{
${ }^{1}$ The restructuring of the saving banks sector and the crisis management framework in Spain are not object of this assessment, and were covered by separate Technical Notes during the FSAP.

2 An CCAA (comunidad autónoma) is the first-level political division in the country. The second Article of the 1978 Constitution recognizes the rights of "nationalities and regions" to self-government and declares the "indissoluble unity of the Spanish nation" (such level of decentralization was particularly relevant in the Spanish transition to democracy at the time). There are currently 17 CCAA.
} 


\section{A. Introduction}

6. This assessment of the current state of the implementation of the Basel Core Principles for Effective Banking Supervision (BCP) in Spain has been completed as part of a FSAP update undertaken by the International Monetary Fund (IMF) during February 2012. It reflects the regulatory and supervisory framework in place as of the date of the completion of the assessment. It is not intended to assess the merits of policy and implementation issues regarding European Union (EU) regulatory framework. In addition, it is not intended to represent an analysis of the restructuring processes of the savings banks sector, which is addressed in the broader FSAP exercise.

7. An assessment of the effectiveness of banking supervision requires a review of the legal framework, and detailed examination of the policies and practices of the institutions responsible for banking regulation and supervision. In line with the $\mathrm{BCP}$ methodology, the assessment focused on the $\mathrm{BdE}$ as the main supervisor of the banking system, and did not cover the specificities of regulation and supervision of savings banks, which is a shared responsibility with the CCAAs and would have needed to involve the analysis of local authorities' legislation and supervisory practices. Insofar as prudential regulation of the banking sector and supervisory processes of the BdE are also applied to the Caja segment, this assessment is also applicable to the prudential supervision of Cajas, which is conducted by the BdE. It must be noted that as of the date of this BCP assessment, almost all the Cajas, with two small exceptions, have transferred their banking activities to commercial banks (although the ownership structure of the new banks may still retain some characteristics of the Caja governance), therefore the role of CCAA supervision in the financial sector could at this point be considered reduced, and this assessment should provide a clear picture of the current supervisory process applicable to the whole banking sector.

\section{B. Information and Methodology Used for Assessment}

8. The Spanish authorities agreed to be assessed according to the Core Principles (CP) Methodology issued by the BCP (Basel Committee) in October 2006. The current assessment was thus performed according to a revised content and methodological basis as compared with the previous BCP assessment carried out in 2006. It is important to note, for completeness' sake, that the two assessments will not be directly comparable, as the revised BCP have a heightened focus on risk management and its practice by supervised institutions and its assessment by the supervisory authority, raising the bar to measure the effectiveness of a supervisory framework.

9. To assess compliance, the BCP Methodology uses a set of essential and additional assessment criteria for each principle. The essential criteria (EC) are the only elements on which to gauge full compliance with a CP. The additional criteria (AC) are suggested best practices against which the Spanish authorities have agreed to be assessed. $\mathrm{AC}$ are commented on but are not reflected in the grading. The assessment of compliance 
with each principle is made on a qualitative basis. A four-part grading system is used: compliant; largely compliant; materially noncompliant; and noncompliant. This is explained below in the detailed assessment section. The assessment of compliance with each CP is made on a qualitative basis to allow a judgment on whether the criteria are fulfilled in practice. Effective application of relevant laws and regulations is essential to provide indication that the criteria are met.

10. The assessment team reviewed the framework of laws, rules, and guidance and held extensive meetings with officials of the BdE, and additional meetings with the MoE, rating agencies, auditing firms, and banking sector participants. The authorities provided a self-assessment of the CPs rich in quality and comprehensiveness, as well as detailed responses to additional questionnaires, and facilitated access to supervisory documents and files, staff and systems.

\section{The team appreciated the very high quality of cooperation received from the} authorities. The team extends its thanks to staff of the authorities who provided excellent cooperation, including extensive provision of documentation and access, at a time when staff was burdened by many initiatives related to the domestic situation, as well as European and global regulatory initiatives which are in progress.

\section{The standards were evaluated in the context of the Spanish financial system's} structure and complexity. The $\mathrm{CP}$ must be capable of application to a wide range of jurisdictions whose banking sectors will inevitably include a broad spectrum of banks. To accommodate this breadth of application, a proportionate approach is adopted within the CP, both in terms of the expectations on supervisors for the discharge of their own functions and in terms of the standards that supervisors impose on banks. An assessment of a country against the EC must, therefore, recognize that its supervisory practices should be commensurate with the complexity, interconnectedness, size, and risk profile and crossborder operation of the banks being supervised. In other words, the assessment must consider the context in which the supervisory practices are applied. The concept of proportionality underpins all assessment criteria. For these reasons, an assessment of one jurisdiction will not be directly comparable to that of another.

13. An assessment of compliance with the BCPs is not, and is not intended to be, an exact science. Reaching conclusions required judgments by the assessment team. ${ }^{3}$ The Spanish banking system was undergoing a deep reform when the assessment took place, and while much of the supervisor's attention was focused on these circumstances, the reform was prompting further evolution of the already advanced practices for supervision. Nevertheless, by adhering to a common, agreed methodology, the assessment should provide the Spanish authorities with an internationally consistent measure of the quality of its banking

3 The assessment team comprised Fabiana Melo and Josè Tuya. 
supervision in relation to the CPs, which are internationally acknowledged as minimum standards.

14. To determine the observation of each principle, the assessment has made use of five categories: compliant; largely compliant, materially noncompliant, noncompliant, and non-applicable. An assessment of "compliant" is given when all EC are met without any significant deficiencies, including instances where the principle has been achieved by other means. A "largely compliant" assessment is given when there are only minor shortcomings, which do not raise serious concerns about the authority's ability to achieve the objective of the principle and there is clear intent to achieve full compliance with the principle within a prescribed period of time. A principle is considered to be "materially noncompliant" in case of severe shortcomings, despite the existence of formal rules and procedures and there is evidence that supervision has clearly not been effective, the practical implementation is weak or that the shortcomings are sufficient to raise doubts about the authority's ability to achieve compliance. A principle is assessed "noncompliant" if it is not substantially implemented, several EC are not complied with, or supervision is manifestly ineffective. Finally, a category of "non-applicable" is reserved (though not used in this case) for those cases that the criteria would not relate the country's circumstances.

\section{Institutional and Macroeconomic Setting and Market Structure-Overview ${ }^{4}$}

\section{Spain is experiencing the bursting of a real estate bubble after a decade of} excesses. Construction and real estate loans grew from 10 percent of GDP in 1992 to 43 percent in 2009, and amounted to about 37 percent of GDP at end-2011. Spanish banks funded their increasing exposures largely in capital markets and abroad. The reversal of the domestic expansion and the onset of the Euro area debt crisis exposed Spain's vulnerabilities from accumulated domestic and external imbalances and pushed the economy into a sharp recession in 2009-10, and unemployment is over 21 percent.

\section{The rapid economic expansion in the last decade has been mirrored in the}

banking industry. Banks play a pivotal role in the Spanish financial system. The total assets of the Spanish banking sector amount to about 320 percent of GDP, with five banks accounting for more than 70 percent of total assets. Commercial and savings banks dominate, with more than 90 percent of deposits and loans. Nonbank financial entities represent a small share of the financial sector (less than 5 percent of total assets).

17. Significant consolidation has taken place in the savings bank sector. The reforms to the legal framework together with financial support from the state-owned recapitalization vehicle, the Fondo de Reestructuración Ordenada Bancaria (FROB), were instrumental in reform process. The number of institutions has been reduced from 45 to 18 , through

\footnotetext{
${ }^{4}$ This section draws from other documents produced for the FSAP, which at the time of this draft were not yet finalized.
} 
intervention, mergers, or takeovers. Tighter capital requirements led many savings bank groups to spin off their banking activities into newly created commercial banks. The FROB has taken over five institutions ( 8 percent of the system); one intervened bank was recently auctioned off, another is in the pipeline, and the takeover of a small, ailing bank is underway.

\section{Despite the reform measures and balance sheet repair by banks, the sector} remains under severe pressure. Spanish banks have been able to raise capital from private sources, some of which through the exchange of convertible instruments, in response to the requirements of the European Banking Authority (EBA), but profitability has deteriorated. The uncertainty surrounding the valuation of real estate collateral has led the government to issue a new set of measures in February, while the mission was in the field, requiring additional capital and provisioning for problematic exposures to real estate and new measures to encourage further consolidation in the financial sector.

\section{In Spain, the regulation and supervision of financial institutions and securities} markets is performed by three main agencies. Oversight of credit institutions is the responsibility of the BdE (although regional governments retain some regulatory and supervisory powers over the savings banks operating in their jurisdictions); securities markets are supervised by the Comisión Nacional del Mercado de Valores (CNMV); supervision of insurance companies and pension funds is under the mandate of the Dirección General de Seguros y Fondos de Pensiones (DGSFP) within the MoE. Oversight and supervisory responsibilities regarding payments and settlements systems are the purview of the BdE and the CNMV, respectively.

20. In 2006, the authorities established a financial stability committee, Comité de Estabilidad Financiera (CESFI), in which the three agencies are represented, together with the State Secretary for Economic Affairs acting as Chair. The objective was to strengthen coordination and exchange of information among the three institutions; the CESFI does not have any decision-making powers of its own.

\section{Preconditions for Effective Banking Supervision ${ }^{5}$}

\section{The legal and regulatory framework for transparency and governance of} publicly traded institutions has improved significantly in recent years. ${ }^{6}$ In particular, since 2006, for traded companies and issuers whose securities are traded on an official secondary market, financial statements must be prepared in accordance with International Financial Reporting Standards (IFRS) for consolidated statements and domestic Spanish

\footnotetext{
${ }^{5}$ This section draws from the assessment of resolution and safety nets framework conducted in the FSAP.

${ }^{6}$ Full International Organization of Securities Commissions (IOSCO) and International Association of Insurance Supervisors (IAIS) Insurance Core Principles (ICP) assessments were conducted during the FSAP, as well as a review of the crisis management and resolution framework and financial markets infrastructure, therefore these topics will not be detailed in this document.
} 
standards for individual financial statements. Domestic Spanish standards are almost fully assimilated to IFRS, with differences only in that Spanish standards allow capitalizing research expenses and do not provide options available under IFRS, in connection with the valuation of certain assets (mainly real state and intangible assets).

22. Instituto de Contabilidad y Auditoría de Cuentas (ICAC) is the body responsible for setting Spanish accounting standards and providing interpretation and guidance on their use. It is a government entity, attached to the MoE. Any proposal to change the accounting standards must be subject to consultation with the Consultative Committee on Accounting Standards of ICAC, where the CNMV, the BdE, the DGSF participate along with representatives from the professional bodies, issuers and investors. The final decision belongs to the Accounting Council of ICAC, which is composed of the President of ICAC and representatives from the CNMV, the BdE, and the DGSP. BdE has the delegated authority from the MoE to establish accounting standards for banks, in which they coordinate with ICAC.

23. The BdE as a member of the Eurosystem may provide Emergency Liquidity Assistance (ELA) within the restrictions of the System. ELA may only be provided to an individual credit institution which is considered solvent but which faces temporary liquidity problems. A national central bank which provides ELA must supply the ECB with a predefined set of information. While granting the ELA remains a decision of the national central bank, carried at the risk of said bank, liquidity support through ELA is subject to consultation with the ECB Governing Council when the amount of the ELA is above a predefined threshold. During the recent crisis there was one case of ELA use, after which the BdE has fine-tuned its protocol for the provision of liquidity in emergency situations.

\section{The financial safety net institutional framework is complemented by two other}

agencies, Fondo de Garantía de Depósitos (Depositor Guarantee Fund - FGD) and the FROB. The FGD does not act as a mere pay-box but it has in conjunction with the BdE a wide range of intervention powers and it has been the main crisis management "instrument" until the creation of the FROB, which was created in June 2009 to assisting and fostering the reorganization of the Spanish banking industry, especially savings banks.

\section{The FGD is a private legal entity wholly prefunded by the member credit}

institutions. Originally, there were three FGDs; one for each sector of the banking industry (commercial banks, savings banks, and credit cooperatives). With the Royal Decree-Law 16/2011 of October 14, 2011, the three sectoral funds were merged into a single fund and the premiums have been made uniform. The Management Board of the FDG consists of 12 members: six from the BdE and two from each of the commercial bank, savings bank and cooperatives sectors; the chairman is the Deputy Governor of the BdE. Certain major decisions - such as on provision of financial assistance in resolution and on the collection of extraordinary premiums - are subject to a two-third majority of its members. Members' contributions are the main source of funding but the FDG may also be funded by 
extraordinary contributions; and by issuing bonds or by borrowing from third parties, including the Government or the FROB.

\section{The FGD resources may be used for preventive measures and bank} reorganization under specific safeguards. When a problematic situation in a bank is detected, the BdE will inform the FGD. The bank must present an Action Plan to the BdE on the measures needed to resolve the problem. If the BdE accepts the Action Plan, the Management Board of the FGD will decide whether to provide any financial support aimed at restoring the viability of the bank. The range of financing mechanisms that the FGD can deploy is broad and includes both liquidity and solvency support. RDL 16/2011, of October 14, 2011, (as amended by Royal Decree-law 19/2011), has further widened the FGD's options for supporting bank resolution, as it authorizes the FGD to make nonrefundable contributions in the process of restructuring and resolution of viable and nonviable institutions, including those intervened or recapitalized by the FROB. In case of bank liquidation, neither the FGD nor depositors enjoy any preferential rights over the estate of a failed bank.

\section{The explicit objective of the FROB is to assist and foster the reorganization of} the Spanish banking industry (Royal Decree Law 9/2009). The FROB has legal personality and full public and private capacity. The FROB received its initial capital from FGD and from the state. The FROB can issue securities guaranteed by the state (and/or it can seek other funding) up to three times its capital, but it can leverage up to six times with the approval of the Minister of Finance and Public Administrations. With the recent Royal Decree Law 2/2012 the resources of the FROB have been raised. The FROB is administered by a governing committee named by the MoE, formed by nine members: four are proposed by the $\mathrm{BdE}$, including the deputy governor who acts as chairperson, two members are from the MoE; and three members representing the FGDs.

28. The resolution and intervention framework is shared among these authorities. $\mathrm{BdE}$ is the triggering authority, determining that the solvency and liquidity of a bank is jeopardized, and activating intervention. When BdE determines that the entity is not viable, it appoints FROB as administrator, with managerial powers over the entity. FROB makes an inventory of the bank's condition, prepares and submits to the $\mathrm{BdE}$ a restructuring plan, spelling out all the possible measures to restore the viability of the institution or to resolve it (mergers, P\&As - which may be subject to shareholders/creditors' consent). The plan needs to be approved by the BdE in order to be carried out. At any point in time, the FROB may provide financial support to the problem bank (the same could be done by the FGD once the restructuring plan has been approved). At the same time that the FROB submits to the BdE the restructuring plan, it provides also a report to the MoE and the Minister of Finance and Public Administrations analyzing the impact of the plan on the public finances. The Minister of Finance and Public Administrations may object to the plan, based on its evaluation of such impact. If the restructuring plan is not successful, the alternative would be the revocation of the bank license (by the Council of Ministers) and, in case of insolvency of the entity, the 
initiation of a court-driven bankruptcy process. ${ }^{7}$ The resolution authorities, in principle, BdE, FROB and MoE, cannot fully allocate losses to shareholders and creditors, or revoke a license (except the MoE in specific cases provided in law), which makes the resolution process somewhat convoluted.

\section{E. Main Findings}

\section{Objectives, independence, powers, transparency, and cooperation (CP 1)}

29. As noted in the previous FSAP, the dual legal framework governing Cajas poses the risk of potential conflicts in the exercise of supervisory and sanctioning authority. Some areas where responsibilities overlap between BdE and CCAA - for instance, governance and sanctioning, are directly related to reputational risk and risk management, which affect solvency. The fragmentation of CCAA supervision over such issues may have played a role in the deterioration of the situation of saving banks sector. The lack of clarity brings reputational risk to the $\mathrm{BdE}$, and the 2006 FSAP recommendation that the legal regime be reinforced is still valid. It must be noted that since all but two Cajas have transferred their banking activities to commercial banks, the issue will become less relevant as the governance of the new institutions become closer to that of listed commercial banks and CCAA role in the supervision of banking activities diminishes.

\section{Other 2006 FSAP recommendations have been magnified with the perspective} given by the events from 2007 to 2011. Since the last FSAP, and given the saving banks restructuring process in Spain, some market participants have expressed concerns about BdE's independence, particularly due to the apparent delays in implementation of corrective actions and sanction. This concern is triggered as the market is well aware of the thoroughness of BdE's supervision - while the sanctioning proposals are made by the Governing Council of BdE to the Minister of Economy, who has sanctioning power for very serious infractions and resolution capacity. The legal framework also establishes the MoE as the principal agency charged with issuing financial regulation. Assessors have not seen any evidence of government or industry interference in the operation of supervision and budget of supervision in BdE. However, the presence of a government member in the governance structure of the BdE, combined with the legal framework for sanctions and regulation powers, does not create an environment conducive to independence. It is striking that the law clearly distinguishes the independence and regulatory capacity of BdE in its monetary authority role from its supervisory role. As prudential regulation in Spain depends on governmental action, changes in the regulatory framework tend to follow the political cycle and may result in delays in the issuance of critical regulations. The broad presence of the $\mathrm{MoE}$ in the supervisory and regulatory hierarchy clouds the independence of a well

\footnotetext{
${ }^{7}$ The revocation of the license based on its insolvency triggers a court administered process. If the institution is not insolvent (voluntary liquidation) there is no need to involve court proceedings.
} 
conducted and highly technical supervisory body, and ultimately undermines the credibility and effectiveness of the supervision.

\section{Licensing and structure (CPs 2-5)}

31. The ongoing restructuring process in the financial sector will bring challenges to supervision with respect to structure and governance of banks. The MoE is the licensing authority, based on an analysis by BdE of the compliance with the licensing criteria established in law. The BdE is then responsible for supervising the ongoing compliance with the licensing criteria in the life of the institution. On the other hand, BdE is the authority responsible authorizing and monitoring significant transfers of ownership and major acquisitions. The framework has improved since the last FSAP and a closer monitoring of the structure of banks is carried out, in particular given the expansion of seguimiento continuado approach to more financial institutions. In that sense, the peculiar situation of new commercial banks created as the result of the reform of the Cajas should be carefully followed by authorities, insofar as the new shareholder entities (no longer conducting banking business) have no identifiable ownership and frequently have close links to the local industrial and political environment given their social services objectives. This situation has the potential to create detrimental influence over the bank's operations and soundness. Supervision of such institutions needs to be tailored to these special characteristics.

\section{Prudential regulation and requirements (CPs 6-18)}

32. Pillar 2 implementation has been a significant focus for the BdE. A standard format was designed for the banks to report on their Internal Capital Adequacy Assessment Program (ICAAP). The reporting was initiated in 2008 and has been revised to capture additional information and provide further guidance to the banks. The BdE staff meets with the banks annually to discuss the report. The results of the report are used in evaluating the banks' risk profile. There has been significant consolidation in the financial system creating challenges for banks to integrate risk management systems.

33. Concentration risk and related party lending played a significant role in recent cases of distressed financial institutions, in particular Cajas de Ahorros. These Cajas, given their local characteristics and business nature, presented both high sectoral (real estate) and geographical concentration, but economic sector concentration also affected many banks. In addition, in Spain many linkages between industrial companies and banks remain, and the organizational structures are often complex and related parties difficult to detect. Related party lending was an important source of lower quality credit that played a role in the savings banks crisis, due to both exposures to non-consolidated real estate enterprises and in certain cases, exposures to public entities or organizations linked to members of governance bodies of the Cajas. The application of an enhanced regulatory framework within Pillar II and more intensive monitoring and control of such risks under seguimiento continuado is recent, and is not yet fully applied to all institutions in the system. Going forward, the complex 
organizational and governance structures of the new commercial banks presents particular challenges to supervision of these risks.

34. Loan loss provisioning has been robust but had to be supplemented in February 2012 due to the continued economic decline. At the start of the crisis existing provisions, built through the dynamic provisioning framework, enabled banks to meet the increased specific provisions required by a deteriorating loan portfolio but the continued crisis has prompted additional provisioning. The decline in real estate prices and the dearth of transactions highlighted weaknesses in the real estate appraisal methodology, which becomes very difficult in the absence of market transactions, resulting in valuations that were based in too optimistic discount rates and execution periods. To address these issues a Royal Decree Law was issued imposing extraordinary provisioning levels on substandard and doubtful loans secured by land of by real estate developments.

35. A new law on anti-money laundering and combating the financing of terrorism (AML/CFT) was adopted in 2010. The responsibility for enforcing and monitoring compliance with AML/CFT regulation rests with Servicio Ejecutivo de la Comisión de Prevención del Blanqueo de Capitales (SEPBLAC). However, the BdE also plays an important role as in its compliance inspections; it also reviews the banks' systems for AML/CFT and follows up on deficiencies. The BdE and Sepblac collaborate closely and perform joint inspections when warranted.

\section{Methods of ongoing banking supervision (CPs 19-21)}

36. The BdE has a risk-based supervisory model supported by a strong technical staff and a well-developed information technology system. Onsite and offsite staff is integrated and both participate in onsite inspections. The primary supervisory instruments are the onsite inspection and permanent onsite presence at many of the banks (at the time of the assessment, there was permanent onsite presence at 16 of the banks).

37. A risk-based matrix is developed for each bank. The supervisory team assigned to a bank develops a risk matrix by rating the level of risk in a number of categories of banking activity. The matrix also includes elements of corporate governance, concentrations risk and operational risk. The matrix also describes the risk direction as stable, increasing or declining. Based on the results, the annual supervisory plan is developed.

\section{The informational technology infrastructure greatly enhances supervisory} efficiency and risk monitoring. The supervisory staff has access to a vast amount of information with systems that facilitate the manipulation of the data. In addition to financial information, there is an electronic file system where an audit trail is available of all the supervisory reports, activities and issues related to a bank, including all inputs by inspectors. 
Accounting and disclosure (CP 22)

39. The BdE is the body responsible for issuing accounting standards and has a working relationship with the audit industry. The BdE meets annually with auditors and discusses issues of concern and audit scopes. The annual audit produces a report for the BdE addressing the banks' compliance with BdE requirements and an evaluation of the loan portfolio. Disclosure in Spain is extensive and in recent stress tests there has been transparency in result reporting. accounting and disclosure

Corrective and remedial powers of supervisors (CP 23)

40. The BdE has a broad range of supervisory enforcement authority. However, the adoption of new regulations to implement Pillar 2, the current crisis and the pace at which deterioration can occur in the integrated global market indicate the need for flexible actions that can be applied at an earlier stage to effect corrective action. The enforcement practice employed by the BdE follows a deliberate, well-documented approach that has reduced the need for sanctions. In the current environment, it is unclear whether implementation of all the enforcement tools available to the BdE while it searched for a systemic solution, was held in abeyance in expectation of a quick resolution of the weak banks or underestimation of the duration and depth of the economic crisis.

Consolidated and cross-border banking supervision (CPs 24-25)

41. The BdE has broad authority to conduct consolidated supervision. BdE is empowered to supervise banks on a solo and consolidated basis, including all the offices or entities within the group, irrespective of their location or legal structure.

42. Consolidated supervision is primarily based on the information compiled by the parent bank in order to manage the risks and controls of the group as a whole. Parent banks are subject to mandatory detailed regular reporting to the BdE, which also covers internal global risk management and information on internal controls. Additionally, the BdE coordinates and exchanges information with domestic and foreign supervisors to accomplish a full view of risk.

43. Through supervisory colleges and on a bilateral basis, the BdE collaborates with home-host supervisors. The BdE conducts supervisory colleges for its two largest banks and for a medium-sized bank and has signed MOUs with relevant supervisors. The BdE coordinates the supervisory activities of these three banking groups with host supervisors and relies on their reports. 
Table 1A. Summary Compliance with the Basel Core Principles-ROSCs

\begin{tabular}{|c|c|}
\hline Core Principle & Comments \\
\hline \multicolumn{2}{|l|}{$\begin{array}{l}\text { 1. Objectives, independence, powers, } \\
\text { transparency, and cooperation }\end{array}$} \\
\hline 1.1 Responsibilities and objectives & $\begin{array}{l}\text { In spite of court decisions on the distribution } \\
\text { of supervisory responsibilities between BdE } \\
\text { and CCAA with respect to Cajas, there is still } \\
\text { some overlap of responsibilities. For } \\
\text { instance, governance and sanctioning, which } \\
\text { are under CCAA supervision, are directly } \\
\text { related to reputational risk and risk } \\
\text { management, which affect solvency - which } \\
\text { would fall under BdE's supervisory realm. } \\
\text { The fragmentation of CCAA supervision over } \\
\text { such issues may have played a role in the } \\
\text { deterioration of the situation of saving banks } \\
\text { sector. The lack of clarity brings reputational } \\
\text { risk to the BdE, to the extent that the } \\
\text { oversight of deep problems in institutions } \\
\text { under co-supervision, and the continuing } \\
\text { condition concerns facing the banks resulting } \\
\text { from the Cajas' restructuring process, may } \\
\text { be publicly attributed to failures in BdE's } \\
\text { supervisory action even when there were } \\
\text { supposed to be responsibilities shared with } \\
\text { or of exclusive competence of the CCAA. } \\
\text { The issue may become less relevant as the } \\
\text { supervisory role of CCAA over banking } \\
\text { activities diminishes with the restructuring of } \\
\text { the sector }\end{array}$ \\
\hline $\begin{array}{l}1.2 \text { Independence, accountability and } \\
\text { transparency }\end{array}$ & $\begin{array}{l}\text { Some market participants have expressed } \\
\text { concerns about BdE's independence, } \\
\text { particularly due to the apparent delays in } \\
\text { implementation of corrective actions and } \\
\text { sanction. This concern is triggered as the } \\
\text { market is well aware of the thoroughness of } \\
\text { BdE's supervision-while the sanctioning } \\
\text { proposals are made by the Governing } \\
\text { Council of BdE to the Minister of Economy, } \\
\text { who has sanctioning power for very serious } \\
\text { infractions and resolution capacity. } \\
\text { Assessors have not seen any evidence of } \\
\text { government and industry interference in the } \\
\text { operation of supervision and budget of } \\
\text { supervision in BdE. However, the } \\
\text { involvement of political bodies such as the } \\
\text { CCAAs and the MoE in licensing, } \\
\text { sanctioning and resolution does create an } \\
\text { environment for potential influence. In }\end{array}$ \\
\hline
\end{tabular}




\begin{tabular}{|c|c|}
\hline & $\begin{array}{l}\text { addition, the presence of the Secretary } \\
\text { General of the Treasury in the Board of BdE, } \\
\text { with voting capacity in what concerns } \\
\text { issuance of prudential regulation, nomination } \\
\text { of senior supervisory staff and allocation of } \\
\text { supervisory budget (LABE Articles } 20 \text { and } \\
21 \text { ), as well as on the sanctions with fall } \\
\text { under the capacity of the BdE (less serious } \\
\text { and serious infractions) is not conducive to } \\
\text { independence. }\end{array}$ \\
\hline 1.3 Legal framework & $\begin{array}{l}\text { The supervisory authority cannot update } \\
\text { prudential rules without changing laws. It is } \\
\text { striking that the law clearly distinguishes the } \\
\text { regulatory capacity of BdE in its monetary } \\
\text { policy role from its supervisory role. As } \\
\text { already stated in the } 2006 \text { Fsap, "there is a } \\
\text { risk that the BdE may be unable to respond } \\
\text { adequately should there be conflicting } \\
\text { interests between the institutional goals of } \\
\text { the BdE and the government, which could } \\
\text { undermine BE's supervisory independence." } \\
\text { Changes in the prudential framework follow } \\
\text { the political cycle, because prudential } \\
\text { regulation is done through laws (approved by } \\
\text { the legislative body) or the government. This } \\
\text { may have allowed for the accumulation of } \\
\text { problems, and created an environment of } \\
\text { regulatory uncertainty. }\end{array}$ \\
\hline 1.4 Legal powers & $\begin{array}{l}\text { On the powers to require prompt remedial } \\
\text { action and impose sanctions, there are } \\
\text { material deficiencies. While the supervisors } \\
\text { can and-as the assessors were shown } \\
\text { evidence-do send recommendations and } \\
\text { requirements to banks, sanctioning powers } \\
\text { are lacking. This had already been raised in } \\
\text { the previous FSAP, which recommended } \\
\text { transferring sanctioning powers currently } \\
\text { under the MoE to BdE. While authorities } \\
\text { have informed there has never been a case } \\
\text { of a sanction that, once recommended by } \\
\text { BdE, has failed to be imposed by MoE, the } \\
\text { fact that the Secretary General of the } \\
\text { Treasury is a voting member of the } \\
\text { Governing Council on the proposals of } \\
\text { sanctions that are to be raised to the MoE for } \\
\text { decision, diminishes the significance of the } \\
\text { prior argument. According to the } 2010 \\
\text { Supervision Report (Memoria de } \\
\text { Supervision), from } 2007 \text { to } 2010 \text { only one } \\
\text { sanctioning procedure was initiated against } \\
\text { banks, and two against saving banks, }\end{array}$ \\
\hline
\end{tabular}




\begin{tabular}{|c|c|}
\hline & $\begin{array}{l}\text { although several of these institutions had } \\
\text { serious deficiencies in management and } \\
\text { solvency in the period. } \\
\text { The lack of coercive powers taints the } \\
\text { results of a well conducted and highly } \\
\text { technical supervisory body, and may } \\
\text { ultimately undermine the credibility and } \\
\text { effectiveness of the supervision. Also see CP } \\
\text { 23-enforcement tools to protect bank } \\
\text { capital and avoid asset dissipation were not } \\
\text { widely used. }\end{array}$ \\
\hline 3. Licensing criteria & $\begin{array}{l}\text { The licensing authority is the MoE, and the } \\
\text { reasons for the denial of licenses, based on } \\
\text { BdE's report, are clearly stated in Law. There } \\
\text { is no provision in the Law, however, that } \\
\text { prevents the MoE from providing a license } \\
\text { over the contrary opinion of BdE. There is, } \\
\text { therefore, no certainty that MoE's } \\
\text { understanding of fit and proper, adequacy of } \\
\text { controls, and organizational structure, will } \\
\text { coincide with the supervisory authority and } \\
\text { therefore not hinder effective supervision. } \\
\text { The authorities report that this has never } \\
\text { been the case in practice, and the level of } \\
\text { prescriptiveness in the legislation makes this } \\
\text { result unlikely. The assessors did review two } \\
\text { complete cases and it seems all due } \\
\text { diligence has been taken by the authorities. } \\
\text { However, it seems that, in the ongoing } \\
\text { reorganization process of the Caja sector, } \\
\text { suitability of shareholders and senior } \\
\text { management has been assumed, as the } \\
\text { shareholders were authorized entities under } \\
\text { CCAA suitability criteria. }\end{array}$ \\
\hline 4. Transfer of significant ownership & $\begin{array}{l}122 \text { requests for transferring significant } \\
\text { participation have been received in the past } \\
5 \text { years, all but one have been approved. } \\
\text { Each application may involve one or more } \\
\text { interested parties. Some of these are } \\
\text { reorganization within the entity, including } \\
\text { creation of special purpose vehicle (SPVs) } \\
\text { and the segregation of financial activities of } \\
\text { Cajas into Banks. The rejected application } \\
\text { was related to anti-money laundering and } \\
\text { terrorist financing (AML/FT) restrictions and } \\
\text { structural hindrance to consolidated } \\
\text { supervision concerns. The assessors were } \\
\text { given access to one complete case and also } \\
\text { viewed the database derived from the } \\
\text { supervisory returns. Although the ultimate } \\
\text { ownership is defined, the chain stops at }\end{array}$ \\
\hline
\end{tabular}




\begin{tabular}{|c|c|}
\hline & $\begin{array}{l}\text { shareholders which are listed and/or } \\
\text { disperse shareholder ownership entities } \\
\text { themselves. The peculiar situation of new } \\
\text { commercial banks created as the result of } \\
\text { the reform of the Cajas should be carefully } \\
\text { monitored by authorities, insofar as the new } \\
\text { shareholder entities have no identifiable } \\
\text { ownership and frequently have close links to } \\
\text { the local political environment given their } \\
\text { social services objectives. This situation has } \\
\text { the potential to create detrimental influence } \\
\text { over the bank's operations and soundness. }\end{array}$ \\
\hline 7. Risk management process & $\begin{array}{l}\text { The LC grading in } 2006 \text { was based on the } \\
\text { lack of ability to issue guidance on best } \\
\text { practices and to require correction. The } \\
\text { implementation of EU Directive } 48 / 2006 \text { on } \\
\text { Pillar } 2 \text { has addressed the } 2006 \text { deficiency. } \\
\text { The steps taken to implement Pillar } 2 \\
\text { compliance and monitoring are well-defined } \\
\text { and the Informe de Autoevaluación de } \\
\text { Capital (IAC) report implemented is } \\
\text { comprehensive and provides guidance to } \\
\text { banks for benchmarking. The report was } \\
\text { designed to fit well into supervision by risk } \\
\text { and feeding Supervision of the Banking } \\
\text { Activity by Risk Approach (SABER) and the } \\
\text { supervisory risk matrix. However, the IAC } \\
\text { implementation has been difficult for some } \\
\text { institutions and continues to be adjusted } \\
\text { since initiated in } 2008 \text {, the current version } \\
\text { appears to be very workable. The wave of } \\
\text { mergers and the need for crisis management } \\
\text { has slowed the ICA implementation and } \\
\text { bank-by-bank evaluation, therefore, effective } \\
\text { implementation of this CP in the system, in } \\
\text { particular the new banks, cannot be fully } \\
\text { assessed at this point. }\end{array}$ \\
\hline 9. Problem assets, provisions, and reserves & $\begin{array}{l}\text { The BdE approach to provisioning is } \\
\text { conservative and the use of a dynamic } \\
\text { provisioning element provided an additional } \\
\text { cushion to support the initial effects of the } \\
\text { crisis. As the market conditions deteriorated } \\
\text { in the prolonged crisis, however, it was clear } \\
\text { that the conservativeness of banks' } \\
\text { provisioning was not homogeneous, in } \\
\text { particular with regards to the valuation of real } \\
\text { estate collateral. Therefore, although the } \\
\text { BdE has established detailed loan } \\
\text { classification and provisioning requirements } \\
\text { and its supervisory efforts focus on the } \\
\text { review of the loan portfolio, the system }\end{array}$ \\
\hline
\end{tabular}




\begin{tabular}{|c|c|}
\hline & $\begin{array}{l}\text { results have had to be supplemented by } \\
\text { broader government action. The requirement } \\
\text { for a one-off large catch-up provision for the } \\
\text { system and the large amounts of } \\
\text { provisioning and capital support required in } \\
\text { the conglomeration of savings into } \\
\text { commercial banks indicates that the process } \\
\text { of provisioning did not lead to prompt } \\
\text { adjustments in light of the crisis. BdE is } \\
\text { currently analyzing the framework for the } \\
\text { valuation of real estate collateral in order to } \\
\text { promote a legal revision, and its } \\
\text { implementation should be an important } \\
\text { element for the full compliance with this CP. } \\
\text { Additionally, as it is expected that } \\
\text { dynamic/generic provisioning will fade from } \\
\text { use as a supervisory tool in the new EU } \\
\text { common regulatory framework, provisioning } \\
\text { levels on an ongoing basis will need to be } \\
\text { adjusted to ensure adequacy of credit loss } \\
\text { estimation. }\end{array}$ \\
\hline 10. Large exposure limits & $\begin{array}{l}\text { BdE has extensive information on large } \\
\text { exposures and concentration, provided by } \\
\text { both the quarterly information and the } \\
\text { powerful Central de Información de Riesgos } \\
\text { (CIR) database. Information obtained is input } \\
\text { into the System of Information on Borrowers } \\
\text { (SIA), which analyses the economic and } \\
\text { financial situation of the largest borrowers } \\
\text { (on an individual and consolidated basis) in } \\
\text { the system grades such borrowers for the } \\
\text { exclusive use of the supervision. External } \\
\text { auditors are also required to verify } \\
\text { compliance with large exposures and } \\
\text { concentration rules (long report). The BdE } \\
\text { has been strengthening its monitoring and } \\
\text { control of concentration risk, and the ICAAP } \\
\text { process has included concentration risk in } \\
\text { the determination of additional Pillar } 2 \\
\text { capital. The importance of concentration risk } \\
\text { has been made all the more relevant given } \\
\text { the entrance, in the banking sector, of banks } \\
\text { derived from the consolidation of Cajas de } \\
\text { Ahorros. These Cajas, given their local } \\
\text { characteristics and business nature, } \\
\text { presented both high sectoral (real estate) } \\
\text { and geographical concentration. Economic } \\
\text { sector concentration, in particular, was a } \\
\text { significant factor in recent distressed bank } \\
\text { cases. The application of Pillar } 2 \text { and the } \\
\text { ICCAP process, incorporating sector }\end{array}$ \\
\hline
\end{tabular}




\begin{tabular}{|c|c|}
\hline & $\begin{array}{l}\text { concentration, is recent. As discussed during } \\
\text { the meetings, banks have two options to } \\
\text { calculate additional capital to cover sector } \\
\text { concentration risk, the simplified (ICS- } \\
\text { indice de concentración setorial) and the } \\
\text { internal methodology under Internal Ratings } \\
\text { Based Approach (IRB). Given the high sector } \\
\text { (and geographical) concentration of the } \\
\text { banking system, in particular the newly } \\
\text { formed banks resulting from the restructuring } \\
\text { of the Cajas segment, the assessors are not } \\
\text { confident that the current framework (ICAAP } \\
+ \text { internal controls) is sufficient to cover } \\
\text { concentration risk. }\end{array}$ \\
\hline 11. Exposure to related parties & $\begin{array}{l}\text { The definition seems to be broad enough in } \\
\text { the sense that relationship can be } \\
\text { established indirectly through one or more } \\
\text { "interposed" persons. However, not all } \\
\text { requirements and guidance are based on the } \\
\text { broad definition of related party, and many } \\
\text { focus instead on the "altos cargos" (senior } \\
\text { management). Although BdE does have } \\
\text { information from which supervision can and } \\
\text { does verify, on onsite inspections, if such } \\
\text { exposures are treated in no more favorable } \\
\text { terms than regulation or market conditions } \\
\text { allow, the framework does not seem to cover } \\
\text { adequately conflicts of interest in related } \\
\text { party lending. As in Spain many linkages } \\
\text { between industrial companies and banks } \\
\text { remain, and the organizational structures are } \\
\text { often complex and related parties difficult to } \\
\text { detect, this aspect should deserve additional } \\
\text { attention. Related party lending was an } \\
\text { important source of lower quality credit that } \\
\text { played a role in the savings banks crisis, due } \\
\text { to both exposures to non-consolidated real } \\
\text { estate enterprises and exposures to public } \\
\text { entities or organizations linked to members } \\
\text { of the governance bodies of the Cajas. }\end{array}$ \\
\hline $\begin{array}{l}\text { 23. Corrective and remedial powers of } \\
\text { supervisors }\end{array}$ & $\begin{array}{l}\text { The BdE has a broad range of supervisory } \\
\text { enforcement authority. The process has } \\
\text { worked well for the BdE and the deliberate } \\
\text { approach has reduced the need for } \\
\text { sanctions. The BdE preventive powers have } \\
\text { been enhanced by the adoption of new } \\
\text { regulations to implement Pillar 2, the current } \\
\text { crisis and the pace at which deterioration can } \\
\text { occur in the integrated global market indicate } \\
\text { the need for flexible actions that can be } \\
\text { applied at an earlier stage to effect not only }\end{array}$ \\
\hline
\end{tabular}




\begin{tabular}{|l|l|}
\hline & $\begin{array}{l}\text { corrective action but preventive. The current } \\
\text { crisis has highlighted the need for prompt } \\
\text { corrective action to resolve weak banks and } \\
\text { conserve assets and capital. The BdE should } \\
\text { review of enforcement procedures, including } \\
\text { expediting the process to take earlier actions } \\
\text { such as adding more weight to a written } \\
\text { communication from the inspector at the } \\
\text { conclusion of an inspection or supervisory } \\
\text { activity at banks with ongoing supervision. } \\
\text { Other possible options may include linking } \\
\text { the issuance of letters of requirement to risk- } \\
\text { based benchmarks such as the risk matrix } \\
\text { measurements of trends and the risk rating } \\
\text { assigned to the bank. The paper issued by } \\
\text { the BCBS entitled "Supervisory Guidance on } \\
\text { Dealing with Weak Banks" provides a } \\
\text { number of options for preventive and } \\
\text { corrective action tools }\end{array}$ \\
\hline
\end{tabular}

Table 1B. Summary Compliance with the Basel Core Principles-Detailed Assessments

\begin{tabular}{|c|l|l|}
\hline \multicolumn{1}{|c|}{ Core Principle } & Grading & \multicolumn{1}{|c|}{ Comments } \\
\hline $\begin{array}{l}\text { 1. Objectives, independence, powers, } \\
\text { transparency, and cooperation }\end{array}$ & & \\
\hline 1.1 Responsibilities and objectives & & $\begin{array}{l}\text { In spite of court decisions on the } \\
\text { distribution of supervisory responsibilities } \\
\text { between BdE and CCAA with respect to } \\
\text { Cajas, there is still some overlap of } \\
\text { responsibilities. For instance, } \\
\text { governance and sanctioning, which are } \\
\text { under CCAA supervision, are directly } \\
\text { related to reputational risk and risk } \\
\text { management, which affect solvency- } \\
\text { which would fall under BdE's supervisory } \\
\text { realm. The fragmentation of CCAA } \\
\text { supervision over such issues may have } \\
\text { played a role in the deterioration of the } \\
\text { situation of saving banks sector. The } \\
\text { lack of clarity brings reputational risk to } \\
\text { the BdE, to the extent that the oversight } \\
\text { of deep problems in institutions under } \\
\text { co-supervision, and the continuing } \\
\text { condition concerns facing the banks } \\
\text { resulting from the Cajas' restructuring } \\
\text { process, may be publicly attributed to } \\
\text { failures in BdE's supervisory action even }\end{array}$ \\
\hline \multirow{2}{*}{ LC }
\end{tabular}




\begin{tabular}{|c|c|c|}
\hline & & $\begin{array}{l}\text { when there were supposed to be } \\
\text { responsibilities shared with or of } \\
\text { exclusive competence of the CCAA.. The } \\
\text { issue may become less relevant as the } \\
\text { supervisory role of CCAA over banking } \\
\text { activities diminishes with the } \\
\text { restructuring of the sector. }\end{array}$ \\
\hline $\begin{array}{l}1.2 \text { Independence, accountability } \\
\text { and transparency }\end{array}$ & LC & $\begin{array}{l}\text { Some market participants have } \\
\text { expressed concerns about BdE's } \\
\text { independence, particularly due to the } \\
\text { apparent delays in implementation of } \\
\text { corrective actions and sanction. This } \\
\text { concern is triggered as the market is well } \\
\text { aware of the thoroughness of BdE's } \\
\text { supervision-while the sanctioning } \\
\text { proposals are made by the Governing } \\
\text { Council of BdE to the Minister of } \\
\text { Economy, who has sanctioning power for } \\
\text { very serious infractions and resolution } \\
\text { capacity. Assessors have not seen any } \\
\text { evidence of government and industry } \\
\text { interference in the operation of } \\
\text { supervision and budget of supervision in } \\
\text { BdE. However, the involvement of } \\
\text { political bodies such as the CCAAs and } \\
\text { the MoE in licensing, sanctioning and } \\
\text { resolution does create an environment } \\
\text { for potential influence. In addition, the } \\
\text { presence of the Secretary General of the } \\
\text { Treasury in the Board of BdE, with voting } \\
\text { capacity in what concerns issuance of } \\
\text { prudential regulation, nomination of } \\
\text { senior supervisory staff and allocation of } \\
\text { supervisory budget (LABE Articles } 20 \\
\text { and } 21 \text { ), as well as on the sanctions with } \\
\text { fall under the capacity of the BdE (less } \\
\text { serious and serious infractions) is not } \\
\text { conducive to independence. }\end{array}$ \\
\hline 1.3 Legal framework & MNC & $\begin{array}{l}\text { The supervisory authority cannot update } \\
\text { prudential rules without changing laws. It } \\
\text { is striking that the law clearly } \\
\text { distinguishes the regulatory capacity of } \\
\text { BdE in its monetary policy role from its } \\
\text { supervisory role. As already stated in the } \\
2006 \text { Fsap, "there is a risk that the BdE } \\
\text { may be unable to respond adequately } \\
\text { should there be conflicting interests } \\
\text { between the institutional goals of the } \\
\text { BdE and the government, which could } \\
\text { undermine BE's supervisory } \\
\text { independence." Changes in the }\end{array}$ \\
\hline
\end{tabular}




\begin{tabular}{|c|c|c|}
\hline & & $\begin{array}{l}\text { prudential framework follow the political } \\
\text { cycle, because prudential regulation is } \\
\text { done through laws (approved by the } \\
\text { legislative body) or the government. This } \\
\text { may have allowed for the accumulation } \\
\text { of problems, and created an environment } \\
\text { of regulatory uncertainty. }\end{array}$ \\
\hline 1.4 Legal powers & MNC & $\begin{array}{l}\text { On the powers to require prompt } \\
\text { remedial action and impose sanctions, } \\
\text { there are material deficiencies. While the } \\
\text { supervisors can and-as the assessors } \\
\text { were shown evidence-do send } \\
\text { recommendations and requirements to } \\
\text { banks, sanctioning powers are lacking. } \\
\text { This had already been raised in the } \\
\text { previous FSAP, which recommended } \\
\text { transferring sanctioning powers currently } \\
\text { under the MoE to BdE. While authorities } \\
\text { have informed there has never been a } \\
\text { case of a sanction that, once } \\
\text { recommended by BdE, has failed to be } \\
\text { imposed by MoE, the fact that the } \\
\text { Secretary General of the Treasury is a } \\
\text { voting member of the Governing Council } \\
\text { on the proposals of sanctions that are to } \\
\text { be raised to the MoE for decision, } \\
\text { diminishes the significance of the prior } \\
\text { argument. According to the } 2010 \\
\text { Supervision Report (Memoria de } \\
\text { Supervision), from } 2007 \text { to } 2010 \text { only } \\
\text { one sanctioning procedure was initiated } \\
\text { against banks, and two against saving } \\
\text { banks, although several of these } \\
\text { institutions had serious deficiencies in } \\
\text { management and solvency in the period. } \\
\text { The lack of coercive powers taints the } \\
\text { results of a well conducted and highly } \\
\text { technical supervisory body, and may } \\
\text { ultimately undermine the credibility and } \\
\text { effectiveness of the supervision. Also } \\
\text { see CP } 23 \text { - enforcement tools to protect } \\
\text { bank capital and avoid asset dissipation } \\
\text { were not widely used. }\end{array}$ \\
\hline 1.5 Legal protection & $\mathrm{C}$ & \\
\hline 1.6 Cooperation & C & \\
\hline 2. Permissible activities & $\mathrm{C}$ & \\
\hline 3. Licensing criteria & LC & $\begin{array}{l}\text { The licensing authority is the MoE, and } \\
\text { the reasons for the denial of licenses, } \\
\text { based on BdE's report, are clearly stated } \\
\text { in Law. There is no provision in the Law, }\end{array}$ \\
\hline
\end{tabular}




\begin{tabular}{|c|c|c|}
\hline & & $\begin{array}{l}\text { however, that prevents the MoE from } \\
\text { providing a license over the contrary } \\
\text { opinion of BdE. There is, therefore, no } \\
\text { certainty that MoE's understanding of fit } \\
\text { and proper, adequacy of controls, and } \\
\text { organizational structure, will coincide } \\
\text { with the supervisory authority and } \\
\text { therefore not hinder effective } \\
\text { supervision. The authorities report that } \\
\text { this has never been the case in practice, } \\
\text { and the level of prescriptiveness in the } \\
\text { legislation makes this result unlikely. The } \\
\text { assessors did review two complete } \\
\text { cases and it seems all due diligence has } \\
\text { been taken by the authorities. However, } \\
\text { it seems that, in the ongoing } \\
\text { reorganization process of the Caja } \\
\text { sector, suitability of shareholders and } \\
\text { senior management has been assumed, } \\
\text { as the shareholders were authorized } \\
\text { entities under CCAA suitability criteria. }\end{array}$ \\
\hline 4. Transfer of significant ownership & LC & $\begin{array}{l}122 \text { requests for transferring significant } \\
\text { participation have been received in the } \\
\text { past } 5 \text { years, all but one have been } \\
\text { approved. Each application may involve } \\
\text { one or more interested parties. Some of } \\
\text { these are reorganization within the entity, } \\
\text { including creation of SPVs and the } \\
\text { segregation of financial activities of } \\
\text { Cajas into Banks. The rejected } \\
\text { application was related to AML/FT } \\
\text { restrictions and structural hindrance to } \\
\text { consolidated supervision concerns. The } \\
\text { assessors were given access to one } \\
\text { complete case and also viewed the } \\
\text { database derived from the supervisory } \\
\text { returns. Although the ultimate ownership } \\
\text { is defined, the chain stops at } \\
\text { shareholders which are listed and/or } \\
\text { disperse shareholder ownership entities } \\
\text { themselves. The peculiar situation of } \\
\text { new commercial banks created as the } \\
\text { result of the reform of the Cajas should } \\
\text { be carefully monitored by authorities, } \\
\text { insofar as the new shareholder entities } \\
\text { have no identifiable ownership and } \\
\text { frequently have close links to the local } \\
\text { political environment given their social } \\
\text { services objectives. This situation has } \\
\text { the potential to create detrimental } \\
\text { influence over the bank's operations and }\end{array}$ \\
\hline
\end{tabular}




\begin{tabular}{|c|c|c|}
\hline & & soundness. \\
\hline 5. Major acquisitions & C & \\
\hline 6. Capital adequacy & C & \\
\hline 7. Risk management process & LC & $\begin{array}{l}\text { The LC grading in } 2006 \text { was based on } \\
\text { the lack of ability to issue guidance on } \\
\text { best practices and to require correction. } \\
\text { The implementation of EU Directive } \\
48 / 2006 \text { on Pillar } 2 \text { has addressed the } \\
2006 \text { deficiency. The steps taken to } \\
\text { implement Pillar } 2 \text { compliance and } \\
\text { monitoring are well-defined and the IAC } \\
\text { report implemented is comprehensive } \\
\text { and provides guidance to banks for } \\
\text { benchmarking. The report was designed } \\
\text { to fit well into supervision by risk and } \\
\text { feeding SABER and the supervisory risk } \\
\text { matrix. However, the IAC implementation } \\
\text { has been difficult for some institutions } \\
\text { and continues to be adjusted since } \\
\text { initiated in } 2008 \text {, the current version } \\
\text { appears to be very workable. The wave } \\
\text { of mergers and the need for crisis } \\
\text { management has slowed the ICA } \\
\text { implementation and bank-by-bank } \\
\text { evaluation, therefore, effective } \\
\text { implementation of this CP in the system, } \\
\text { in particular the new banks, cannot be } \\
\text { fully assessed at this point. }\end{array}$ \\
\hline 8. Credit risk & C & \\
\hline $\begin{array}{l}\text { 9. Problem assets, provisions, and } \\
\text { reserves }\end{array}$ & LC & $\begin{array}{l}\text { The BdE approach to provisioning is } \\
\text { conservative and the use of a dynamic } \\
\text { provisioning element provided an } \\
\text { additional cushion to support the initial } \\
\text { effects of the crisis. As the market } \\
\text { conditions deteriorated in the prolonged } \\
\text { crisis, however, it was clear that the } \\
\text { conservativeness of banks' provisioning } \\
\text { was not homogeneous, in particular with } \\
\text { regards to the valuation of real estate } \\
\text { collateral. Therefore, although the BdE } \\
\text { has established detailed loan } \\
\text { classification and provisioning } \\
\text { requirements and its supervisory efforts } \\
\text { focus on the review of the loan portfolio, } \\
\text { the system results have had to be } \\
\text { supplemented by broader government } \\
\text { action. The requirement for a one-off } \\
\text { large catch-up provision for the system } \\
\text { and the large amounts of provisioning } \\
\text { and capital support required in the }\end{array}$ \\
\hline
\end{tabular}




\begin{tabular}{|c|c|c|}
\hline & & $\begin{array}{l}\text { conglomeration of savings into } \\
\text { commercial banks indicates that the } \\
\text { process of provisioning did not lead to } \\
\text { prompt adjustments in light of the crisis. } \\
\text { BdE is currently analyzing the framework } \\
\text { for the valuation of real estate collateral } \\
\text { in order to promote a legal revision, and } \\
\text { its implementation should be an } \\
\text { important element for the full compliance } \\
\text { with this CP. Additionally, as it is } \\
\text { expected that dynamic/generic } \\
\text { provisioning will fade from use as a } \\
\text { supervisory tool in the new EU common } \\
\text { regulatory framework, provisioning levels } \\
\text { on an ongoing basis will need to be } \\
\text { adjusted to ensure adequacy of credit } \\
\text { loss estimation. }\end{array}$ \\
\hline 10. Large exposure limits & LC & $\begin{array}{l}\text { BdE has extensive information on large } \\
\text { exposures and concentration, provided } \\
\text { by both the quarterly information and the } \\
\text { powerful CIR database. Information } \\
\text { obtained is input into the SIA, which } \\
\text { analyses the economic and financial } \\
\text { situation of the largest borrowers (on an } \\
\text { individual and consolidated basis) in the } \\
\text { system grades such borrowers for the } \\
\text { exclusive use of the supervision. } \\
\text { External auditors are also required to } \\
\text { verify compliance with large exposures } \\
\text { and concentration rules (long report). } \\
\text { The BdE has been strengthening its } \\
\text { monitoring and control of concentration } \\
\text { risk, and the ICAAP process has } \\
\text { included concentration risk in the } \\
\text { determination of additional Pillar } 2 \\
\text { capital. The importance of concentration } \\
\text { risk has been made all the more relevant } \\
\text { given the entrance, in the banking } \\
\text { sector, of banks derived from the } \\
\text { consolidation of Cajas de Ahorros. } \\
\text { These Cajas, given their local } \\
\text { characteristics and business nature, } \\
\text { presented both high sectoral (real estate) } \\
\text { and geographical concentration. } \\
\text { Economic sector concentration, in } \\
\text { particular, was a significant factor in } \\
\text { recent distressed bank cases. The } \\
\text { application of Pillar } 2 \text { and the ICCAP } \\
\text { process, incorporating sector } \\
\text { concentration, is recent. As discussed } \\
\text { during the meetings, banks have two }\end{array}$ \\
\hline
\end{tabular}




\begin{tabular}{|c|c|c|}
\hline & & $\begin{array}{l}\text { options to calculate additional capital to } \\
\text { cover sector concentration risk, the } \\
\text { simplified (ICS-indice de concentración } \\
\text { setorial) and the internal methodology } \\
\text { under IRB. Given the high sector (and } \\
\text { geographical) concentration of the } \\
\text { banking system, in particular the newly } \\
\text { formed banks resulting from the } \\
\text { restructuring of the Cajas segment, the } \\
\text { assessors are not confident that the } \\
\text { current framework (ICAAP + internal } \\
\text { controls) is sufficient to cover } \\
\text { concentration risk. }\end{array}$ \\
\hline 11. Exposure to related parties & LC & $\begin{array}{l}\text { The definition seems to be broad enough } \\
\text { in the sense that relationship can be } \\
\text { established indirectly through one or } \\
\text { more "interposed" persons. However, not } \\
\text { all requirements and guidance are based } \\
\text { on the broad definition of related party, } \\
\text { and many focus instead on the "altos } \\
\text { cargos" (senior management). Although } \\
\text { BdE does have information from which } \\
\text { supervision can and does verify, on } \\
\text { onsite inspections, if such exposures are } \\
\text { treated in no more favorable terms than } \\
\text { regulation or market conditions allow, the } \\
\text { framework does not seem to cover } \\
\text { adequately conflicts of interest in related } \\
\text { party lending. As in Spain many linkages } \\
\text { between industrial companies and banks } \\
\text { remain, and the organizational structures } \\
\text { are often complex and related parties } \\
\text { difficult to detect, this aspect should } \\
\text { deserve additional attention. Related } \\
\text { party lending was an important source of } \\
\text { lower quality credit that played a role in } \\
\text { the savings banks crisis, due to both } \\
\text { exposures to non-consolidated real } \\
\text { estate enterprises and exposures to } \\
\text { public entities or organizations linked to } \\
\text { members of the governance bodies of } \\
\text { the Cajas. }\end{array}$ \\
\hline 12. Country and transfer risks & $\mathrm{C}$ & \\
\hline 13. Market risks & $\mathrm{C}$ & \\
\hline 14. Liquidity risk & $\mathrm{C}$ & \\
\hline 15. Operational risk & $\mathrm{C}$ & \\
\hline $\begin{array}{l}16 . \text { Interest rate risk (IRR) in the } \\
\text { banking book }\end{array}$ & C & \\
\hline 17. Internal control and audit & $\mathrm{C}$ & \\
\hline 18. Abuse of financial services & $\mathrm{C}$ & \\
\hline
\end{tabular}




\begin{tabular}{|c|c|c|}
\hline 19. Supervisory approach & $\mathrm{C}$ & \\
\hline 20. Supervisory techniques & $\mathrm{C}$ & \\
\hline 21. Supervisory reporting & $\mathrm{C}$ & \\
\hline 22. Accounting and disclosure & $\mathrm{C}$ & \\
\hline $\begin{array}{l}\text { 23. Corrective and remedial powers of } \\
\text { supervisors }\end{array}$ & LC & $\begin{array}{l}\text { The BdE has a broad range of } \\
\text { supervisory enforcement authority. The } \\
\text { process has worked well for the BdE and } \\
\text { the deliberate approach has reduced the } \\
\text { need for sanctions. The BdE preventive } \\
\text { powers have been enhanced by the } \\
\text { adoption of new regulations to implement } \\
\text { Pillar 2, the current crisis and the pace at } \\
\text { which deterioration can occur in the } \\
\text { integrated global market indicate the } \\
\text { need for flexible actions that can be } \\
\text { applied at an earlier stage to effect not } \\
\text { only corrective action but preventive. The } \\
\text { current crisis has highlighted the need } \\
\text { for prompt corrective action to resolve } \\
\text { weak banks and conserve assets and } \\
\text { capital. The BdE should review of } \\
\text { enforcement procedures, including } \\
\text { expediting the process to take earlier } \\
\text { actions such as adding more weight to a } \\
\text { written communication from the inspector } \\
\text { at the conclusion of an inspection or } \\
\text { supervisory activity at banks with } \\
\text { ongoing supervision. Other possible } \\
\text { options may include linking the issuance } \\
\text { of letters of requirement to risk-based } \\
\text { benchmarks such as the risk matrix } \\
\text { measurements of trends and the risk } \\
\text { rating assigned to the bank. The paper } \\
\text { issued by the BCBS entitled } \\
\text { "Supervisory Guidance on Dealing with } \\
\text { Weak Banks" provides a number of } \\
\text { options for preventive and corrective } \\
\text { action tools. }\end{array}$ \\
\hline 24. Consolidated supervision & $\mathrm{C}$ & \\
\hline 25. Home-host relationships & $\mathrm{C}$ & \\
\hline \multicolumn{3}{|c|}{$\begin{array}{l}\text { Aggregate: Compliant }(\mathrm{C})-19, \text { Largely compliant }(\mathrm{LC})-9, \text { Materially noncompliant }(\mathrm{MNC})-2 \text {, } \\
\text { Noncompliant }(\mathrm{NC})-0, \text { Not applicable (N/A) }-0\end{array}$} \\
\hline
\end{tabular}




\section{F. Recommended Actions and Authorities' Response}

\section{Recommended actions}

Table 2. Recommended Actions to Improve Compliance with the Basel Core Principles

\begin{tabular}{|c|c|}
\hline Reference Principle & Recommended Action \\
\hline 1.1 Responsibilities and objectives & $\begin{array}{l}\text { Change the legal regime to clearly preserve the } \\
\text { sole and exclusive roles of the BdE in prudential } \\
\text { oversight of financial institutions, avoiding any } \\
\text { possible inconsistency in the division of } \\
\text { responsibilities. }\end{array}$ \\
\hline $\begin{array}{l}1.2 \text { Independence, accountability and } \\
\text { transparency }\end{array}$ & $\begin{array}{l}\text { It is recommended that the LABE is amended to } \\
\text { give BdE operational independence in its } \\
\text { supervisory function in line with its independence } \\
\text { as a Eurosystem central bank. } \\
\text { In addition, internal governance structures, such } \\
\text { as selection, nomination and responsibility } \\
\text { processes for supervision could be clear and } \\
\text { publicly available, so that the independence of } \\
\text { supervisory processes is assured and } \\
\text { understood by external parties. }\end{array}$ \\
\hline 1.3 Legal framework & $\begin{array}{l}\text { Introduce changes to the current legal framework } \\
\text { for banking supervision in order to transfer most } \\
\text { regulatory powers currently under the MoE to } \\
\text { enable BdE to promulgate prudential rules. }\end{array}$ \\
\hline 1.4 Legal powers & $\begin{array}{l}\text { Introduce changes to the current legal framework } \\
\text { for banking supervision in order to transfer most } \\
\text { sanctioning powers currently under the MoE to } \\
\text { the BdE. } \\
\text { Consider granting the BE licensing revocation } \\
\text { authority in appropriate circumstances. }\end{array}$ \\
\hline 3. Licensing criteria & $\begin{array}{l}\text { As the restructuring process continues, ensure } \\
\text { that licensing criteria, in particular fit and proper } \\
\text { requirements for senior management, are fully } \\
\text { applied. }\end{array}$ \\
\hline 4. Transfer of significant ownership & $\begin{array}{l}\text { As the restructuring process continues, ensure } \\
\text { that the governance of the new institutions, fully } \\
\text { complies with the requirements of this CP. }\end{array}$ \\
\hline 7. Risk management process & $\begin{array}{l}\text { Ensure that IAC (ICAAP) implementation } \\
\text { continues and it is fully integrated into the BdE's } \\
\text { matrix for the whole system. }\end{array}$ \\
\hline
\end{tabular}




\begin{tabular}{|c|c|}
\hline Reference Principle & Recommended Action \\
\hline 9. Problem assets, provisions, and reserves & $\begin{array}{l}\text { Ensure completion and implementation of the } \\
\text { reforms to the collateral appraisal requirements. } \\
\text { As dynamic provisioning fades from use as a } \\
\text { supervisory tool, review provisioning } \\
\text { requirements to ensure adequacy of loss } \\
\text { protection. }\end{array}$ \\
\hline 10. Large exposure limits & $\begin{array}{l}\text { Improve tools and controls for the effectiveness } \\
\text { of supervision regarding economic sector } \\
\text { concentration, in addition to and within the } \\
\text { existing ICAAP and internal controls framework. } \\
\text { In particular, it is recommended that BdE issues } \\
\text { guidance/regulation specific to sector } \\
\text { concentration (similar to what exist regarding } \\
\text { large exposures). These could include more } \\
\text { detailed requirements in the management of } \\
\text { sector concentration in Circular de Banco de } \\
\text { España (CBE) 3/2008 (Capitulo Noveno), and } \\
\text { internal controls (Capitulo Décimo). Going } \\
\text { forward, banks should be required to purse } \\
\text { adequate diversification, and include the impact } \\
\text { of stress tests in their management of } \\
\text { concentration risk (factoring in effects of } \\
\text { economic downturn in specific sectors, major } \\
\text { decline in values of assets and collateral, etc). } \\
\text { Enhanced requirements for banks could include } \\
\text { the identification, monitoring and management of } \\
\text { exposures where apparently un-correlated } \\
\text { borrowers are exposed to a secondary common } \\
\text { risk factor (for instance, where a bank has } \\
\text { granted a large number of loans to different } \\
\text { employees of a company, sector or local } \\
\text { government). Going forward, reporting and } \\
\text { disclosure of concentration by region and sector } \\
\text { can be improved. While prudential exposure } \\
\text { limits to sector concentration may not be } \\
\text { appropriate in all cases, supervisors should be } \\
\text { able to require limits on a case by case basis, } \\
\text { culminating in a monitorable plan where the bank } \\
\text { commits to reduce its concentration risk to an } \\
\text { acceptable level. The supervisor needs to be } \\
\text { satisfied that the concentration risk is not a cause } \\
\text { of prudential concern. The SREP guidance can } \\
\text { be strengthened in what regards concentration } \\
\text { risk, so that a deeper understanding of the } \\
\text { adequacy of the ICAAP capital coverage for } \\
\text { concentration risk is sufficient. }\end{array}$ \\
\hline
\end{tabular}




\begin{tabular}{|c|c|}
\hline Reference Principle & Recommended Action \\
\hline 11. Exposure to related parties & $\begin{array}{l}\text { Ensure conflict of interest rules are enforced and } \\
\text { related party lending monitored and control tools } \\
\text { are updated, given the new organizational } \\
\text { structure of banking institutions derived from the } \\
\text { restructuring process. }\end{array}$ \\
\hline $\begin{array}{l}\text { 23. Corrective and remedial powers of } \\
\text { supervisors }\end{array}$ & $\begin{array}{l}\text { Review enforcement procedures, to include: } \\
\text { - Implementation of earlier notification to the } \\
\text { bank, of areas for improvement; such as a } \\
\text { required written communication from the } \\
\text { inspector at the conclusion of a supervisory } \\
\text { activity. } \\
\text { - Raise the expectation of supervisory required } \\
\text { action and enforcement based risk-based } \\
\text { benchmarks from the risk matrix and capital } \\
\text { levels. } \\
\text { - In addition to the linear approach to } \\
\text { heightening supervisory pressure on individual } \\
\text { banks also adopt parallel actions to address } \\
\text { individual unsound practices to protect assets } \\
\text { and capital. This was particularly important in } \\
\text { the current crisis as systemic and individual } \\
\text { bank issues needed attention. }\end{array}$ \\
\hline
\end{tabular}

\section{Authorities' response to the assessment ${ }^{8}$}

44. The Spanish authorities (Spanish Treasury and Banco de España) want to express their appreciation to the IMF and its assessment team for this comprehensive assessment of Spain's compliance with the Basel Core Principles for Effective Banking Supervision. The Spanish authorities strongly support the FSAP as a means of promoting the soundness of financial systems as well as of improving supervisory and regulatory practices all over the world. For this reason the authorities welcome this opportunity to comment on the important regulatory reforms Spain is undertaking to improve the soundness of its financial system.

45. The authorities share the main views of the assessment team and appreciate its recommendations. The strength of the Spanish regulatory and supervisory framework was subject to stress during the crisis. The IMF broadly recognizes the determination and effort of the Spanish authorities to address the challenges posed by the crisis. Spain is committed to

\footnotetext{
${ }^{8}$ If no such response is provided within a reasonable time frame, the assessors should note this explicitly and provide a brief summary of the authorities' initial response provided during the discussion between the authorities and the assessors at the end of the assessment mission ("wrap-up meeting").
} 
continue its effort to respond to the crisis and to overcome it successfully. Spain has a long tradition of adherence to the highest international regulatory and supervisory standards and works to improve compliance with the Basel Core Principles on an ongoing basis.

46. Some of the regulatory and supervisory practices commented in this report have actually been improved in parallel to the development of the FSAP missions. The financial reform has been accelerated recently. As a consequence improvements are only partially reflected in the final draft of the assessment. A deep and unprecedented process of restructuring of savings banks is on its way. Professional management teams have been ensured and transparency has been improved. Spain is fully involved in the international efforts to reinforce bank resolution regimes through the implementation of the Financial Stability Board Key Attributes for Effective Resolution Regimes and of the European Commission proposals on crisis management and bank resolution. The Spanish response to the crisis is active, constant and multi-dimensioned. At the same time it is adapted to the special features of the Spanish banking system.

47. The Spanish authorities look forward to continuing their dialogue with the IMF beyond the FSAP exercise. An important experience in the field of cooperation, transparency and best practices has been acquired and must be now appropriately cherished. Spanish authorities are aware of their role in the promotion of international financial stability and declare their willingness to continue working with international counterparts in order to grant it.

48. In addition, the Banco de España would like to add that although it recognizes that the restructuring process has not been sufficiently timely, as is suggested both in the assessment of some of the principles and-more significantly - in the section "Summary, key findings, and recommendations" there are several factors responsible for this, which the Banco de España considers need to be explained in order for the recent restructuring process to be understood:

- $\quad$ First, it is important to take into account that adequate instruments for resolution were not introduced until 2009.

- Second, it is only now with hindsight that we know that the deterioration in the economy was more protracted than initially anticipated by all national and international institutions.

- $\quad$ Third, the successive Spanish governments in power over the period decided and reconfirmed that only limited public funds should be used to rescue banks, thus discarding the 'bad bank' - type alternatives. Other options were considered more appropriate, in part taking into account that the large Spanish banks were not affected, unlike large banks in other countries. This decision was taken not only due to the need to contain the public deficit, but also - and especially — due to the fact that a huge increase in the deficit could lead to an acute sovereign crisis, as has already 
happened in other countries. The decision to implement the restructuring through private solutions has many advantages but is inevitably slower and much more complex and cumbersome to implement than those that-however being more expeditious-involve huge amounts of public resources.

- $\quad$ Fourth, the implementation of a private solution has proven particularly difficult and slow during this crisis because the large international institutions that could have participated in mergers and acquisitions of Spanish institutions were not in a position to do so. For this reason, the private solution was constrained to the domestic level.

- $\quad$ Fifth, during this systemic crisis it was not possible to use the traditional resolution tool of winding-down a bank with write-downs for bondholders. If Spain had been the only country to impose losses on bond holders of medium-sized institutions, the funding for other healthy Spanish institutions would have been seriously impaired. Therefore, the benefits derived from the liquidation of a good number of credit institutions would not have compensated the potential damage to the banking system as a whole and especially to healthier institutions.

- $\quad$ Sixth, the governance of the Cajas also added to the complexity of the restructuring process and affected its speed, due to the strong presence of political and trade union interests in their boards of directors and general meetings. This problem has been mitigated with the transformation of Cajas into banks, but will only disappear if the Cajas lose control over their participated banks.

- $\quad$ Seventh, the fact that the Comunidades Autonomas exercised their power to approve the mergers of Cajas during the restructuring process significantly slowed down the process, given the need to hold long, complex and difficult negotiations with regional governments to reach adequate agreements. This problem has already disappeared thanks to the transformation of Cajas into banks.

49. These are some of the factors that explain why the whole restructuring process was slow and why, against this complex backdrop, the Banco de España had to conduct a large amount of work and was able to take actions only after following a very laborious and cumbersome process.

\section{Detailed ASSESSMent}

\section{Table 3. Detailed Assessment of Compliance with the Basel Core Principles}

\begin{tabular}{|l}
\hline Principle 1. \\
Objectives, autonomy, powers, and resources. An effective system of banking \\
supervision will have clear responsibilities and objectives for each authority involved \\
in the supervision of banks. Each such authority should possess operational \\
independence, transparent processes, sound governance and adequate resources, \\
and be accountable for the discharge of its duties. A suitable legal framework for \\
banking supervision is also necessary, including provisions relating to authorization
\end{tabular}


of banking establishments and their ongoing supervision; powers to address compliance with laws as well as safety and soundness concerns; and legal protection for supervisors. Arrangements for sharing information between supervisors and protecting the confidentiality of such information should be in place.

\begin{tabular}{l} 
Assessment \\
\hline Principle 1(1).
\end{tabular}

Responsibilities and objectives.

An effective system of banking supervision will have clear responsibilities and objectives for each authority involved in the supervision of banks.

\begin{tabular}{|l|}
\hline $\begin{array}{l}\text { Essential } \\
\text { criteria }\end{array}$ \\
\hline EC1
\end{tabular}

Laws are in place for banking, and for the authority (each of the authorities) involved in banking supervision. The responsibilities and objectives of each of the authorities are clearly defined and publicly disclosed.

Description and There is a legal framework in place for banking supervision, which involves the BdE, findings re EC1 the MoE, and in the case of savings banks (Cajas), the CCAA. The core legislation is made up by Law 26/1988, on Discipline and intervention of credit institutions (LDI), Law 13/1994 on the Autonomy of BE (LABE). Per the Spanish Constitution (CE), ${ }^{9}$ CCAA have some supervisory powers over saving banks and cooperatives. In that sense, over the years, constitutional interpretation has been in addition to the powers of BdE and the MoE over the same areas, CCAA also have regulatory and supervisory powers in sanctioning and licensing, corporate governance, consumer protection and transparency, while with the BdE rests supervisory powers over the same institutions with respect to solvency and financial stability. Therefore, for what is under its jurisdiction each CCAA operates and supervises under its own legal framework. The MoE does not have inspection powers but is legally responsible for granting licenses (Article 43 of LDI), imposing sanctions for very serious offenses (see CP 1.4 and 23), deciding on appeals against BdE resolutions (Article 25 of LDI), intervening on the liquidation of credit institutions in certain cases (Article 38 LDI), establishing and modifying accounting standards issuing regulation on loan contracts, lending reporting, electronic banking services and others (Article 48 of LDI). Some of these regulatory powers have been delegated to the BdE (see CP 1.4). The precise supervisory powers of BdE are (Article 7.6 LABE) the compliance with solvency and other legislation and regulations applicable to Credit institutions.

All legislation regarding supervisory attributions is publicly available at the BdE's website, including the legislations issued by each CCAA.

Article 43.bis.1 Law 26/1988: BdE has inspection powers over Spanish credit institutions and their groups, including all the entities of the group and all their offices inside or outside the Spanish jurisdiction. BdE has powers to require the supervised entities all the information needed to perform its supervisory responsibilities. Entities and persons subject to the supervision of BdE are obliged to provide BdE with the information required, including data bases, files and computer programs.

\section{EC2} The laws and supporting regulations provide a framework of minimum prudential standards that banks must meet.

\footnotetext{
${ }^{9}$ The constitutional text does not mention specifically financial supervision, but gives the "central" state jurisdiction over the "Monetary system: foreign currency, exchange and convertibility; bases for the regulations concerning credit, banking and insurance," and "basic rules and coordination of general economic planning," while the CCAA have jurisdiction over "Promotion of economic development of the Self-governing Community within the objectives set by national economic policy."
} 


\begin{tabular}{|c|c|}
\hline $\begin{array}{l}\text { Description and } \\
\text { findings re EC2 }\end{array}$ & $\begin{array}{l}\text { Minimum prudential standards are set both in laws and in regulations. Besides LDI, } \\
\text { main legislation includes Law } 13 / 1985 \text { and Law } 13 / 1992 \text { capital and capital } \\
\text { requirements and consolidated supervision: Royal Decree 216/2008 (capital and } \\
\text { capital requirements) CBE } 3 / 2008 \text { (calculation and control of minimum capital), CBE } \\
4 \text { / } 2004 \text { (disclosure, accounting, supervisory reporting, provisions), Ministerial Order } \\
2899 / 2011 \text { (on transparency and financial services customer protection) (which will } \\
\text { enter into force on April 28, 2012). General guidance on the application of prudential } \\
\text { regulation is also contained in "guias" issued by the BdE, which detail, criteria, } \\
\text { practices and procedures considered suitable by the BdE for compliance of the } \\
\text { regulations. }\end{array}$ \\
\hline EC3 & $\begin{array}{l}\text { Banking laws and regulations are updated as necessary to ensure that they remain } \\
\text { effective and relevant to changing industry and regulatory practices. }\end{array}$ \\
\hline $\begin{array}{l}\text { Description and } \\
\text { findings re EC3 }\end{array}$ & $\begin{array}{l}\text { Banking laws and regulations have been constantly updated to reflect changing } \\
\text { industry and international standards and best practice. Legislative changes can be } \\
\text { promoted at the initiative of the Government, the Congress or Senate (Article } 87.1 \mathrm{CE} \\
\text { or by MoE, and BdE, in their areas of competence. Changes to regulations issued by } \\
\text { BdE can be modified by BdE. Many legislative changes are derived from the } \\
\text { incorporation of EU directives into domestic legal system. Legislation can be quickly } \\
\text { updated, on an urgency basis, by the government through the issuance of Royal } \\
\text { Decree Laws, which have the immediate force of Law but are subject to parliamentary } \\
\text { validation ex-post. Recent increases in capital requirements and provisioning, for } \\
\text { instance, were established by Royal Decree Laws. }\end{array}$ \\
\hline EC4 & $\begin{array}{l}\text { The supervisor confirms that information on the financial strength and performance of } \\
\text { the industry under its jurisdiction is publicly available. }\end{array}$ \\
\hline $\begin{array}{l}\text { Description and } \\
\text { findings re EC4 }\end{array}$ & $\begin{array}{l}\text { BdE requires and confirms that credit institutions publicly disclose accounting } \\
\text { statements, which must follow general commercial law obligations. The quality of such } \\
\text { statements is verified against non-public supervisory reports. Main regulation on } \\
\text { disclosure is CBE } 4 / 2004, \text { but Law } 13 / 1985 \text { also requires the disclosure of prudential } \\
\text { information including internal organization, market strategies, and risk control and } \\
\text { remuneration policies. Detailed information on institutions is also available on the } \\
\text { BdE's website. In addition, BdE publishes on its website twice a year a Report on } \\
\text { Financial Stability updating information on the risks, solvency and profitability of credit } \\
\text { institutions. On an annual basis BdE also publishes its report on the Banking } \\
\text { Supervision, including aggregate information on the performance and solvency of the } \\
\text { Spanish banking system. }\end{array}$ \\
\hline \multicolumn{2}{|l|}{$\begin{array}{l}\text { Additional } \\
\text { criteria }\end{array}$} \\
\hline AC1 & $\begin{array}{l}\text { In determining supervisory programs and allocating resources, supervisors take into } \\
\text { account the risks posed by individual banks and banking groups and the different } \\
\text { approaches available to mitigate those risks. }\end{array}$ \\
\hline $\begin{array}{l}\text { Description and } \\
\text { findings re } A C 1\end{array}$ & $\begin{array}{l}\text { BdE conducts a risk-based supervisory approach (see description in CP 19) by which } \\
\text { supervisory plans and resources can be allocated to the institutions according to their } \\
\text { risk profile and their systemic importance. The supervisory plan is updated at least } \\
\text { yearly and adjusted as needed. }\end{array}$ \\
\hline $\begin{array}{l}\text { Assessment of } \\
\text { Principle 1(1) }\end{array}$ & Largely Compliant \\
\hline Comments & $\begin{array}{l}\text { spite of court decisions on the distribution of supervisory responsibilities between } \\
\text { E and CCAA with respect to Cajas, there is still some overlap of responsibilities. For } \\
\text { tance, governance and sanctioning, which are under CCAA supervision, are directly } \\
\text { ated to reputational risk and risk management, which affect solvency - which would }\end{array}$ \\
\hline
\end{tabular}




\begin{tabular}{|c|c|}
\hline & $\begin{array}{l}\text { fall under BdE's supervisory realm. The fragmentation of CCAA supervision over such } \\
\text { issues may have played a role in the deterioration of the situation of saving banks } \\
\text { sector. In that sense, it is interesting to note that the restructuring of the saving banks } \\
\text { under Article } 7 \text { of Royal Decree-law } 9 / 2009 \text {, for instance, has brought to the BdE the } \\
\text { supervision of corporate governance measures for the institutions involved in the } \\
\text { restructuring process. This is a clear illustration of how the separation of } \\
\text { responsibilities may become blurred and affect supervisory effectiveness. The lack of } \\
\text { clarity brings reputational risk to the BdE, to the extent that the oversight of deep } \\
\text { problems in institutions under co-supervision, and the lack of application of sanctions, } \\
\text { may be publicly attributed to failures in BdE's supervisory action even when there } \\
\text { were supposed to be shared responsibilities. The } 2006 \text { FSAP recommendation that } \\
\text { the legal regime be reinforced "as to clearly preserve the sole and exclusive roles of } \\
\text { the BE in prudential oversight of financial institutions, avoid any possible inconsistency } \\
\text { in the division of responsibilities, and enhance coordination of the supervisory bodies" } \\
\text { is therefore still valid. The issue may become less relevant as the role of CCAA } \\
\text { diminishes with the restructuring of the sector and governance structures are modified. }\end{array}$ \\
\hline Principle 1(2). & $\begin{array}{l}\text { Independence, accountability and transparency. Each such authority should } \\
\text { possess operational independence, transparent processes, sound governance and } \\
\text { adequate resources, and be accountable for the discharge of its duties. }\end{array}$ \\
\hline \multicolumn{2}{|l|}{$\begin{array}{l}\text { Essential } \\
\text { criteria }\end{array}$} \\
\hline EC1 & $\begin{array}{l}\text { The operational independence, accountability and governance structures of each } \\
\text { supervisory authority are prescribed by law and publicly disclosed. There is, in } \\
\text { practice, no evidence of government or industry interference which compromises the } \\
\text { operational independence of each authority, or in each authority's ability to obtain and } \\
\text { deploy the resources needed to carry out its mandate. The head(s) of the supervisory } \\
\text { authority can be removed from office during his (their) term only for reasons specified } \\
\text { in law. The reason(s) for removal should be publicly disclosed. }\end{array}$ \\
\hline $\begin{array}{l}\text { Description and } \\
\text { findings re EC1 }\end{array}$ & $\begin{array}{l}\text { The operational independence BdE as a central bank within the Eurosystem, following } \\
\text { EC standards, has been established by the LABE, which states that the BdE is not } \\
\text { subject to the general government administration legislation, such as public budget, } \\
\text { property and procurement (Articles } 1.2 \text { and } 4.1 \text { ). There are, however, distinctions } \\
\text { made in the law in respect to the monetary policy functions and supervisory functions } \\
\text { of the BdE, in particular with respect to its regulatory and sanctioning powers. (See } \\
\text { CP } 1.3 \text { and 1.4). } \\
\text { As per the LABE, the governance structure of the BdE is composed of two bodies, the } \\
\text { governing council and the executive committee. The governing council members, } \\
\text { besides the governor and the deputy governor, are the Secretary General of the } \\
\text { Treasury, the Vice President of CNMV and six members appointed by the } \\
\text { government. The Secretary General of the Treasury and the Vice President of CNMV } \\
\text { cannot vote in matters related to monetary policy, but can vote in respect to matters } \\
\text { related with banking supervision. The Minister for Economy may participate, without } \\
\text { voting capacity, in Council meetings. The executive committee is composed of the } \\
\text { governor, deputy governor, and two of the six council members. } \\
\text { The Governor and Deputy Governor are appointed simultaneously for a } 6 \text { year period } \\
\text { and cannot be renewed in office (Article } 25.1 \text { LABE). The appointment is made by the } \\
\text { government and must be justified by the MoE to the Congress. Both Governor and } \\
\text { deputy governor can only be dismissed in the cases established by Article } 25.4 \text { LABE, }\end{array}$ \\
\hline
\end{tabular}




\begin{tabular}{|c|c|}
\hline & $\begin{array}{l}\text { which are expiration of their term, resignation, reaching } 70 \text { years, dismissal by the } \\
\text { Government on grounds of mental incapacity, serious breach of their obligations, } \\
\text { overcome incompatibility during their term or prosecution on a serious criminal } \\
\text { offence. The past } 3 \text { governors served their full mandates. } \\
\text { The heads of supervision and regulation are usually, but not necessarily, career } \\
\text { employees, and have no term of service, but can be removed only by ) reaching of } \\
70 \text { years of age; b) retirement; c) resignation; d) resolution adopted by the Executive } \\
\text { Committee of the BdE, following Governor's proposal; e) dismissal due to disciplinary } \\
\text { proceeding according to the internal labour rules of the BdE; f) incompatibility that may } \\
\text { have arisen during the term of office; or g) prosecution for wilful misconduct. The same } \\
\text { Article } 74 \text { of the Internal Rules of BdE (IRBE) sets out the same grounds for dismissal } \\
\text { of the rest of General Directors of the BdE. }\end{array}$ \\
\hline EC2 & $\begin{array}{l}\text { The supervisor publishes objectives and is accountable through a transparent } \\
\text { framework for the discharge of its duties in relation to those objectives. }\end{array}$ \\
\hline $\begin{array}{l}\text { Description and } \\
\text { findings re EC2 }\end{array}$ & $\begin{array}{l}\text { BdE's supervisory objectives are stated by law and published. In addition, the BdE } \\
\text { publishes an Annual Report on Banking Supervision in Spain (Memoria Anual), which } \\
\text { describes the actions taken during the year and includes a statement of the internal } \\
\text { audit of BdE on the procedural appropriateness of the decision taken by the regulation } \\
\text { and the supervision departments. The "memoria" has to be approved by the governing } \\
\text { council and submitted to parliament. The law requires the annual report and accounts } \\
\text { of the BdE are submitted to congress for information and to the MoE for approval } \\
\text { (Article } 4.2 \text { LABE). The annual report also includes a section on supervisory activities } \\
\text { and their results (Article } 21.1 \mathrm{c} \text { - LABE and Additional Disposition } 8^{\text {a } L D I) . ~ T h e ~ B d E ~} \\
\text { accounts are subject to external audit, according to Eurosystem requirements and the } \\
\text { Spanish Court of Audits (Tribunal de Cuentas) (Article } 31 \text { IRBE and } 4.2 \text { LDI). } \\
\text { In addition, following the disclosure requirements set out in EU Directives, BdE and } \\
\text { CNMV have set up a joint and single website which provides detailed information } \\
\text { about prudential supervision of credit institutions and investment firms. }\end{array}$ \\
\hline EC3 & $\begin{array}{l}\text { The supervisory authority and its staff have credibility based on their professionalism } \\
\text { and integrity. }\end{array}$ \\
\hline $\begin{array}{l}\text { Description and } \\
\text { findings re EC3 }\end{array}$ & $\begin{array}{l}\text { The governor and deputy governor are appointed by the government, and are required } \\
\text { to have competence in monetary or banking affairs. Council members are also } \\
\text { appointed by the government and to have competence in economics or law } \\
\text { (Articles } 24.1 \text { and } 24.3 \text { of LABE). There are requirements related to conflict of interest } \\
\text { applicable both to the Governor and Deputy Governor and the members of the } \\
\text { governing council (only teaching positions are allowed, investments restricted, etc- } \\
\text { Articles } 26 \text { and } 28 \text { of LABE). The Governor and Deputy Governor at the end of their } \\
\text { office cannot hold any employment related to credit institutions and securities markets } \\
\text { for a two years period. An internal Code of Conduct is applicable to all BdE staff, } \\
\text { which contains rules dealing with conflict of interests, professional secrecy and } \\
\text { disclosure of confidential information. Interviews with the industry confirm that the } \\
\text { supervisory teams are qualified and professionally respected. }\end{array}$ \\
\hline EC4 & $\begin{array}{l}\text { The supervisor is financed in a manner that does not undermine its autonomy or } \\
\text { independence and permits it to conduct effective supervision and oversight. This } \\
\text { includes: } \\
\text { - A budget that provides for staff in sufficient numbers and with skills } \\
\text { commensurate with the size and complexity of the institutions supervised. }\end{array}$ \\
\hline
\end{tabular}




\begin{tabular}{|c|c|}
\hline & $\begin{array}{l}\text { - Salary scales that allow it to attract and retain qualified staff. } \\
\text { - The ability to commission outside experts with the necessary professional skills } \\
\text { and independence and subject to necessary confidentiality restrictions to } \\
\text { conduct supervisory tasks. } \\
\text { - A training budget and program that provides regular training opportunities for } \\
\text { staff. } \\
\text { - A budget for computers and other equipment sufficient to equip its staff with the } \\
\text { tools needed to review the banking industry and assess individual banks and } \\
\text { banking groups. } \\
\text { - A travel budget that allows appropriate on-site work. }\end{array}$ \\
\hline $\begin{array}{l}\text { Description and } \\
\text { findings re EC4 }\end{array}$ & $\begin{array}{l}\text { According to LABE, the Governing Council establishes its budget for operating costs } \\
\text { and investments, which is referred to the Government who presents it to the } \\
\text { Parliament for approval. It is not to be consolidated with any other public sector } \\
\text { budget. Funding seems to be stable and sufficient, as demonstrated by the steady } \\
\text { training activities, hiring of staff and conduct of on-site activities (see CP } 19 \text { and 20). } \\
\text { The new supervisory approach which relies on more intensive on-site supervision of a } \\
\text { larger number of banks might have an impact on resources, which the authorities need } \\
\text { to assess. There also seems to be some fatigue on staff directly related to crisis } \\
\text { management and problem banks, given the long duration of the crisis. }\end{array}$ \\
\hline \multicolumn{2}{|l|}{$\begin{array}{l}\text { Additional } \\
\text { criteria }\end{array}$} \\
\hline AC1 & The head(s) of the supervisory authority is (are) appointed for a minimum term. \\
\hline $\begin{array}{l}\text { Description and } \\
\text { findings re } A C 1\end{array}$ & $\begin{array}{l}\text { The Governor and Deputy Governor are appointed simultaneously for a six year } \\
\text { period and cannot be renewed in office. }\end{array}$ \\
\hline $\begin{array}{l}\text { Assessment of } \\
\text { Principle 1(2) }\end{array}$ & Largely compliant \\
\hline Comments & $\begin{array}{l}\text { Since the last Fsap, and given the saving banks restructuring process in Spain, some } \\
\text { market participants have expressed concerns about BdE's independence, particularly } \\
\text { due to the apparent delays in implementation of corrective actions and sanction. This } \\
\text { concern is triggered as the market is well aware of the thoroughness of BdE's } \\
\text { supervision-while the sanctioning proposals are made by the Governing Council of } \\
\text { BdE to the Minister of Economy, who has sanctioning power for very serious } \\
\text { infractions and resolution capacity. Assessors have not seen any evidence of } \\
\text { government and industry interference in the operation of supervision and budget of } \\
\text { supervision in BdE. However, the involvement of political bodies such as the CCAAs } \\
\text { and the MoE in licensing, sanctioning and resolution does create an environment for } \\
\text { potential influence. This assessment is considering such matters under CP } 1.3 \text { and } \\
\text { 1.4. In addition, the presence of the Secretary General of the Treasury in the Board of } \\
\text { BdE, with voting capacity in what concerns issuance of prudential regulation, } \\
\text { nomination of senior supervisory staff and allocation of supervisory budget (LABE } \\
\text { Articles } 20 \text { and 21), as well as on the sanctions with fall under the capacity of the BdE } \\
\text { (less serious and serious infractions) is not conducive to independence. In that sense, } \\
\text { the explicit distinction made in LABE in respect to the monetary policy functions and } \\
\text { supervisory functions of the BdE is a source of concern. It is recommended that the } \\
\text { LABE is amended to give BdE operational independence in its supervisory function in } \\
\text { line with its independence as a Eurosystem central bank. This would not hamper } \\
\text { coordination in systemic crisis situations, as other mechanisms are being put in place } \\
\text { (see CP 1.6). In addition, internal governance structures, such as selection, } \\
\text { nomination and responsibility processes for supervision could be clear and publicly }\end{array}$ \\
\hline
\end{tabular}




\begin{tabular}{|c|c|}
\hline & $\begin{array}{l}\text { available, so that the independence of supervisory processes is assured and } \\
\text { understood by external parties. }\end{array}$ \\
\hline Principle 1(3). & $\begin{array}{l}\text { Legal framework. A suitable legal framework for banking supervision is also } \\
\text { necessary, including provisions relating to authorization of banking establishments and } \\
\text { their ongoing supervision. }\end{array}$ \\
\hline \multicolumn{2}{|l|}{$\begin{array}{l}\text { Essential } \\
\text { criteria }\end{array}$} \\
\hline EC1 & $\begin{array}{l}\text { The law identifies the authority (or authorities) responsible for granting and } \\
\text { withdrawing banking licenses. }\end{array}$ \\
\hline $\begin{array}{l}\text { Description and } \\
\text { findings re EC1 }\end{array}$ & $\begin{array}{l}\text { Both Royal Decree } 1245 / 95 \text {, Article } 1.1, \text { (creation of banks) and LDI (Article } 43.1 \text { ) } \\
\text { clearly attribute to the MoE the authority for granting licenses, after consultation with } \\
\text { the BdE. The licensing authority for savings banks is each CCAA (see CP 1.1). } \\
\text { Withdrawal of licenses, according to Article } 57 \text { bis of the Banking Law of } 31 \text { December } \\
1946 \text { (BL), is the responsibility of the Council of Ministers, based on the proposal of } \\
\text { the MoE. The withdrawal of license can be taken by the MoE directly in the cases of } \\
\text { i) exclusion from the deposits guarantee scheme, ii) cease of activities, iii) court } \\
\text { resolution providing for the opening of the liquidation within a bankruptcy procedure, } \\
\text { iv) branches whose principal authorization has been withdrawn by its home authority. }\end{array}$ \\
\hline EC2 & $\begin{array}{l}\text { The law empowers the supervisor to set prudential rules (without changing laws). The } \\
\text { supervisor consults publicly and in a timely way on proposed changes, as appropriate. }\end{array}$ \\
\hline $\begin{array}{l}\text { Description and } \\
\text { findings re EC2 }\end{array}$ & $\begin{array}{l}\text { The LABE fully entitles the BdE to adopt all necessary rules to exercise its functions } \\
\text { as a monetary authority (Article 3-Circulares monetarias) but not for its functions as } \\
\text { supervisory authority. The issuance by BdE of Circulares necessary for prudential } \\
\text { supervision is only allowed if expressly empowered under different laws and } \\
\text { regulations. This empowerment may be done directly by the text of law or by } \\
\text { delegation from the MoE through Ministerial Orders. Currently the BdE has the power } \\
\text { to adopt Circulares on accounting standards, consumer transparency (both by } \\
\text { delegation of the MoE), and aspects of solvency which have already been detailed in } \\
\text { laws, Royal Decrees or MO. Law } 13 / 1985 \text { empowers BdE to issue guidelines on } \\
\text { prudential matters, as well as to adopt as its own guidelines issued by international } \\
\text { bodies. Such guidelines are not enforceable, but used to substantiate supervisory } \\
\text { judgment and orient banks towards best practices. BdE is required to consult with } \\
\text { stakeholders before issuing Circulares according to its internal rules. Depending on } \\
\text { the subject of the rule, BdE requests the opinion from other authorities and agencies } \\
\text { and from the affected entities, through their professional associations and public } \\
\text { consultations. } \\
\text { Delegated powers can and are overridden by Government in several instances. For } \\
\text { instance, in the course of the assessment RDL } 2 / 2012 \text { was issued, modifying aspects } \\
\text { of prudential regulation and accounting which had been previously regulated by BdE. }\end{array}$ \\
\hline EC3 & $\begin{array}{l}\text { The law or regulations empower the supervisor to obtain information from the banks } \\
\text { and banking groups in the form and frequency it deems necessary. }\end{array}$ \\
\hline $\begin{array}{l}\text { Description and } \\
\text { findings re EC3 }\end{array}$ & $\begin{array}{l}\text { Through delegated power from the MoE ( } 48.1 \mathrm{LDI} \text { and OM de } 31 / 3 / 1989) \mathrm{BE} \text { can } \\
\text { establish accounting standards as well as the frequency and granularity of supervisory } \\
\text { reporting and public disclosure. More recent amendments to LDI (Article } 43 \text { bis } \\
\text { Section } 1 \text { bis) have expanded existing powers of the BdE to request from both entities } \\
\text { and individuals any information (including access to records, softwares, files and } \\
\text { databases) needed to assess compliance with the regulation and other provisions. }\end{array}$ \\
\hline
\end{tabular}




\begin{tabular}{|c|c|}
\hline & $\begin{array}{l}\text { Information is therefore also frequently requested and provided on a case by case as } \\
\text { necessary. } \\
\text { It must be noted that in licensing processes the supervisor is not entitled to request } \\
\text { information directly to the applicant. Requests need to be channelled to the MoE. }\end{array}$ \\
\hline $\begin{array}{l}\text { Assessment of } \\
\text { Principle 1(3) }\end{array}$ & Materially Non-Compliant \\
\hline Comments & 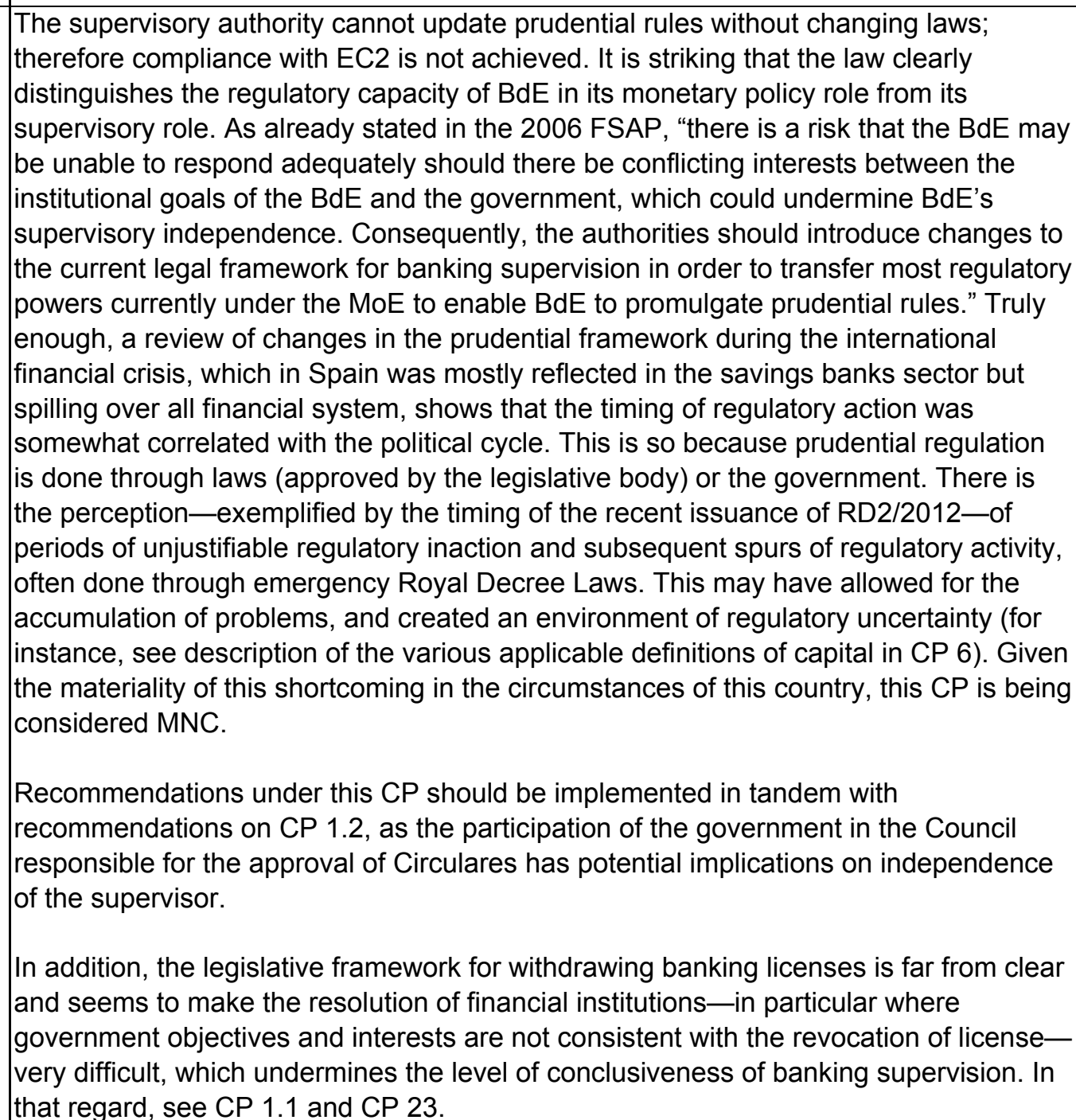 \\
\hline Principle 1(4). & $\begin{array}{l}\text { Legal powers. A suitable legal framework for banking supervision is also necessary, } \\
\text { including powers to address compliance with laws as well as safety and soundness } \\
\text { concerns. }\end{array}$ \\
\hline \multicolumn{2}{|l|}{$\begin{array}{l}\text { Essential } \\
\text { criteria }\end{array}$} \\
\hline EC1 & $\begin{array}{l}\text { The law and regulations enable the supervisor to address compliance with laws and } \\
\text { the safety and soundness of the banks under its supervision. The law and regulations } \\
\text { permit the supervisor to apply qualitative judgment in safeguarding the safety and } \\
\text { soundness of the banks within its jurisdiction. }\end{array}$ \\
\hline $\begin{array}{l}\text { Description and } \\
\text { findings re EC1 }\end{array}$ & $\begin{array}{l}\text { LABE (Article 7.6) and LDI (Article } 43 \text { bis) provide the legal framework for supervisory } \\
\text { action. Article 7.6 LABE states that BdE is responsible for the supervision "as }\end{array}$ \\
\hline
\end{tabular}




\begin{tabular}{|c|c|}
\hline & $\begin{array}{l}\text { disposed by law, of the solvency, operations and compliance with regulations," without } \\
\text { prejudice to the prudential supervision carried out by the CCAA in their area of } \\
\text { responsibility. Article } 7.5 \text { of LABE adds to BdE's responsibility to ensure the smooth } \\
\text { operation and the stability of the financial system. LABE (7.7) states that BdE can } \\
\text { engage in the necessary activities to perform these functions. It is not clear to what } \\
\text { extent qualitative judgment was liked to specific supervisory action before the } \\
\text { amendments made in } 2007 \text { of Law } 13 / 1985 \text {, which introduced enhanced powers to } \\
\text { supervise adequacy of internal controls, risk management and capital allocation in a } \\
\text { broader understanding of "solvency" and stability (Article } 6 \text { and Article } 10 \text { bis of Law } \\
13 / 1985 \text { ). In addition, such review of risk management was made mandatorily annual } \\
\text { only with another amendment to Law } 13 / 1985 \text { made in } 2011 \text {. Since the introduction of } \\
\text { Pillar } 2 \text { powers in November } 2007 \text { (Article } 11 \text { ), the BdE can take measures if the } \\
\text { banks fall below the minimum capital adequacy ratio (CAR) "or the additional } \\
\text { requirements made by BdE" and determines that BdE can require, based on lack of } \\
\text { adequate capital or internal controls, some measures "if it considers improbable that } \\
\text { other measures may improve the situation in an adequate timeframe." Such measures } \\
\text { are more capital (only in case of "particularly grave structural deficiencies"), } \\
\text { reinforcement of controls, require more provisioning or increased risk weights for credit } \\
\text { transactions, or reduction of risk exposure, reduce business and close branches, and } \\
\text { reduce executives compensation. (See EC3 on corrective actions). }\end{array}$ \\
\hline EC2 & $\begin{array}{l}\text { The supervisor has full access to banks' board, management, staff and records in } \\
\text { order to review compliance with internal rules and limits as well as external laws and } \\
\text { regulations. }\end{array}$ \\
\hline $\begin{array}{l}\text { Description and } \\
\text { findings re } E C 2\end{array}$ & $\begin{array}{l}\text { As mentioned in CP 1.3, LDI: (Article } 43 \text { bis Section } 1 \text { bis) empowered the BdE to } \\
\text { request from both entities and individuals under its supervision any information } \\
\text { (including access to records, softwares, files and databases) needed to assess } \\
\text { compliance with the regulation and discipline provisions they are subject to. BdE } \\
\text { performs onsite and off-site supervision and in its ongoing supervision has access to } \\
\text { the banks' board, and senior management, and records, including minutes of the } \\
\text { board and risk and audit committees. For many of the banks under permanent } \\
\text { intensive supervision, supervisors have real time access to information systems. }\end{array}$ \\
\hline EC3 & $\begin{array}{l}\text { When, in a supervisor's judgment, a bank is not complying with laws or regulations or } \\
\text { it is or is likely to be engaged in unsafe and unsound practices, the supervisor has the } \\
\text { power to: } \\
\text { - Take (and/or require a bank to take) prompt remedial action. } \\
\text { - Impose a range of sanctions (including the revocation of the banking license). }\end{array}$ \\
\hline $\begin{array}{l}\text { Description and } \\
\text { findings re EC3 }\end{array}$ & $\begin{array}{l}\text { The legal powers of BdE's remedial and sanctioning powers are defined by the } \\
\text { Banking Law of 1946, the LABE and in particular LDI. The Banking Law of 1946, } \\
\text { Article 47, states that BdE can "draw the attention" of the bank's board and senior } \\
\text { management when it believes the dividend policy of the institution is not adequate to } \\
\text { the situation and perspectives of its business, even when compliant with minimum } \\
\text { mandatory requirements. If the bank does not abide by the recommendation, the MoE, } \\
\text { based on BdE's proposal, may ask the recommendation to be read in the next } \\
\text { shareholders meeting. Article } 23 \text { (f) of LABE that BdE's Executive Committee may } \\
\text { formulate recommendations and requirements to banks (see CP 23), as well as to } \\
\text { inform their Boards of sanctioning procedures under BdE's jurisdiction which are being } \\
\text { taken against the institution or its administrators. }\end{array}$ \\
\hline
\end{tabular}


instance, very grave infractions include the exercise of unauthorized mergers and acquisitions, maintaining a CAR below 80 percent of minimum for over six months, keeping irregular or misleading accounting, resisting supervisory authority, provision of false information to shareholders and stakeholders, and endangering the prudent and sound management of a credit entity by means of influence of a significant participation holder. Amendments introduced in 2007 include as very grave infraction non-compliance with the requirements that $\mathrm{BdE}$ may have made on a case by case base in terms of provisions, treatment of assets or risk reduction, in the timeframe agreed with $\mathrm{BdE}$, and since 2005 deficiencies in organization and internal controls when they endanger the solvency of the institution can be considered very grave infractions. It is also a very grave infraction the reincidence of a grave infraction within a 5 year period. Grave infractions are the occasional exercise of unauthorized activities, and breaches in capital requirements and other mandatory limits (when not considered very grave). Minor infractions are those which are not very grave and grave.

Title I Chapter III of the LDI contains the system of sanctions. They are basically the same for all infractions, the gradation being the level of the financial penalty, public (for very grave or grave) or private (for minor) advertence, and finally the revocation of license for very serious infractions. For all infractions, it is possible to impose, in addition to sanctions against the entities, sanctions against the senior management who may have been found responsible for the infraction. These include financial penalties and, for very grave infractions: (a) suspension from exercise of their office for no more than three years; (b) removal from office, with disqualification from holding directorships or management offices in the same credit institution during a maximum of five years; and (c) disqualification from holding directorships or management posts in any credit or financial-sector institution and, where applicable, removal from the directorship or management post held by the infringing person at a credit institution, for a period of not more than ten years.

For grave infractions sanctions against the senior management include disqualification from holding directorships or management posts in any credit or financial-sector institution and, where applicable, removal from the directorship or management post held by the infringing person at a credit institution, for a period of not more than one year and public or private advertencies.

Arts 4 and 5 describe the very grave and grave infractions, while the principles for the distinction between them, depending on the circumstances, are provided in Article 14. For example, internal controls deficiencies and failure to comply with individual requirements by BdE may be considered both grave and very grave. To make the distinction, authorities will need to consider the nature of the entity, the danger or damage caused, the profit obtained, the systemic importance of the entity, the consequences to the financial sector, previous record in compliance with regulation, etc.

Article $18 \mathrm{LDI}$, the competence for conducting the sanctioning proceedings and the power to impose sanctions for serious and minor infractions is entrusted to the $\mathrm{BdE}$, while the authority to impose sanctions for very serious infractions rests with the MoE. According to LABE Article 21, it is with the Governing Council of the BdE the responsibility to impose the sanctions under BdE's jurisdiction, and to decide which proposals for very grave sanctions should be elevated to the Minister. 


\begin{tabular}{|c|c|}
\hline & $\begin{array}{l}\text { The imposition of the sanction of revocation of the authorization of a bank, however, is } \\
\text { reserved to the Council of Ministers, upon proposal of the MoE (Article } 57 \text { bis of the } \\
\text { Banking Law of 1946), and restricted to the situations listed in that Article (which } \\
\text { include insufficiency of funds, sanctions under LDI, false information provided during } \\
\text { authorization, exclusion for the deposit insurance scheme, absence of banking } \\
\text { operations for over six months). } \\
\text { Article } 31 \text { of LDI empowers BdE to intervene in a bank or to provisionally replace its } \\
\text { board of directors or management bodies, in cases where such bank is in an } \\
\text { exceptionally serious situation that jeopardizes the adequacy of its own resources or } \\
\text { its stability, liquidity or solvency. These intervention or replacement measures shall be } \\
\text { adopted by the BdE, giving a reasoned explanation of their adoption to the MoE. }\end{array}$ \\
\hline $\begin{array}{l}\text { Assessment of } \\
\text { Principle 1(4) }\end{array}$ & Materially Non Compliant \\
\hline Comments & 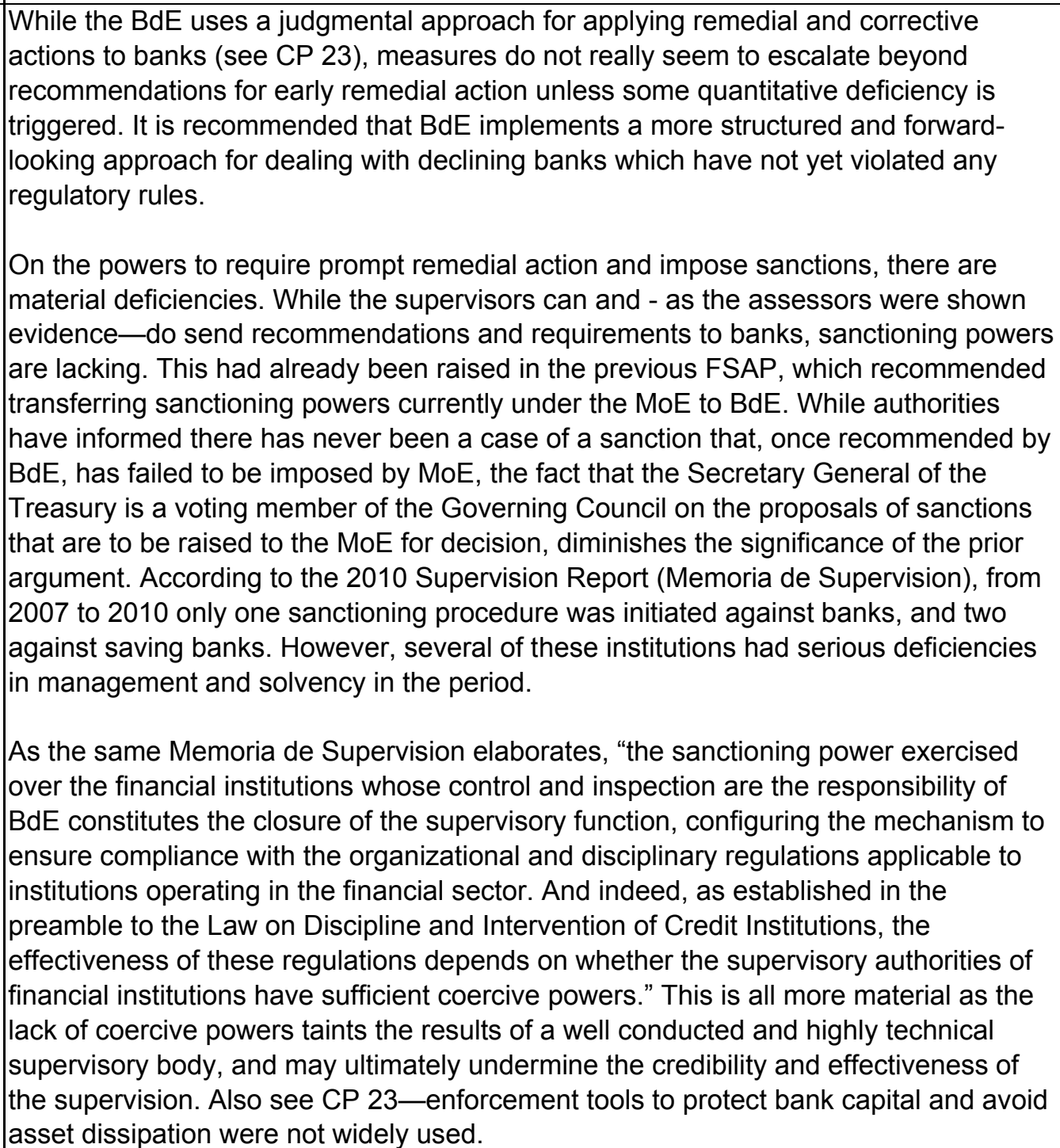 \\
\hline Principle 1(5). & $\begin{array}{l}\text { Legal protection. A suitable legal framework for banking supervision is also } \\
\text { necessary, including legal protection for supervisors. }\end{array}$ \\
\hline
\end{tabular}




\begin{tabular}{|c|c|}
\hline $\begin{array}{l}\text { Essential } \\
\text { criteria }\end{array}$ & \\
\hline EC1 & $\begin{array}{l}\text { The law provides protection to the supervisory authority and its staff against lawsuits } \\
\text { for actions taken and/or omissions made while discharging their duties in good faith. }\end{array}$ \\
\hline $\begin{array}{l}\text { Description and } \\
\text { findings re EC1 }\end{array}$ & $\begin{array}{l}\text { The CE states that public institutions are only materially responsible for claims under } \\
\text { certain conditions set by law. Law } 30 / 1992 \text { establishes that citizens are entitled } \\
\text { compensation from any harm suffered in result of the operation of public service, and } \\
\text { the BdE supervisory practice is subject to the this law. In case claims under Law } \\
30 / 1992 \text { are initiated, internal regulations of the BdE (Articles } 25 \text { and } 26 \text { ) establish that } \\
\text { the BdE assumes the legal management, defense, and legal advice of its employees } \\
\text { and members of their governing bodies, even when the employment relationship or } \\
\text { link with such person has ceased at the time of initiation of the proceeding. }\end{array}$ \\
\hline EC2 & $\begin{array}{l}\text { The supervisory authority and its staff are adequately protected against the costs of } \\
\text { defending their actions and/or omissions made while discharging their duties in good } \\
\text { faith. }\end{array}$ \\
\hline $\begin{array}{l}\text { Description and } \\
\text { findings re EC2 }\end{array}$ & $\begin{array}{l}\text { The internal regulation also establishes that the BdE will assume all financial and } \\
\text { compensatory liability resulting from offenses or omissions committed by the } \\
\text { authorities or its staff in the performance of their duties, including posting guarantees } \\
\text { or sureties in civil or criminal claims. }\end{array}$ \\
\hline $\begin{array}{l}\text { Assessment of } \\
\text { Principle 1(5) }\end{array}$ & Compliant \\
\hline Comments & $\begin{array}{l}\text { There have been } 78 \text { cases of appeal and litigation before courts involving the BdE } \\
\text { within the last five years. All cases have been ruled favourably to the BdE. }\end{array}$ \\
\hline Principle 1(6). & $\begin{array}{l}\text { Arrangements for sharing information between supervisors and protecting the } \\
\text { confidentiality of such information should be in place. }\end{array}$ \\
\hline & \\
\hline EC1 & $\begin{array}{l}\text { Arrangements, formal or informal, are in place for cooperation and information sharing } \\
\text { between all domestic authorities with responsibility for the soundness of the financial } \\
\text { system, and there is evidence that these arrangements work in practice, where } \\
\text { necessary. }\end{array}$ \\
\hline $\begin{array}{l}\text { Description and } \\
\text { findings re EC1 }\end{array}$ & $\begin{array}{l}\text { Cooperation among the supervisors is prescribed by Law. LDI (Article 43bis) states } \\
\text { that all entities of any Spanish public administration must collaborate with BE. The } \\
\text { three financial sector supervisors-BdE, CNMV, and the DGSFP_have signed } \\
\text { bilateral Memoranda of Understanding (MoU) for cooperation, which includes the } \\
\text { sharing of confidential supervisory information. BdE and DGSFP's MoU was signed in } \\
2004 \text {; BdE and CNMV's MoU was updated in 2009. In addition, in } 2006 \text { the three } \\
\text { supervisory authorities and the MoE signed a multilateral MoU for financial stability } \\
\text { and the prevention and management of systemic crises, which resulted in the creation } \\
\text { of the CESFI. Cooperation is also facilitated by the shared members of the governing } \\
\text { bodies of the CNMV and BdE, where the other authority is represented. Aside from } \\
\text { that, there are legal provisions that establish the coordination of activities between the } \\
\text { BdE and CNMV, and mandatory reciprocal consultation in issues such as sanctioning } \\
\text { and licensing. The three financial supervisors involved have confirmed full cooperation } \\
\text { and access of information. } \\
\text { Law } 30 / 1992 \text { (Article 4) establishes that "all relationships between national supervisors } \\
\text { and the CCAA which have assumed supervisory powers are subject to the general } \\
\text { principle of collaboration and mutual assistance between public administrations," and } \\
\text { the LABE and Law } 31 / 1985 \text { state clearly that the BdE "may establish agreements with }\end{array}$ \\
\hline
\end{tabular}




\begin{tabular}{|c|c|}
\hline & $\begin{array}{l}\text { the CCAA on discipline and inspection" (LABE Article } 7.6 \text { and } 7.8) \text {. No MoUs have } \\
\text { been signed with any of the CCAA, however, the BdE informs cooperation is smooth } \\
\text { (assessors where shown some examples of correspondence but did not contact } \\
\text { CCAA to verify on cooperation). }\end{array}$ \\
\hline EC2 & $\begin{array}{l}\text { Arrangements, formal or informal, are in place, where relevant, for cooperation and } \\
\text { information sharing with foreign financial sector supervisors of banks and banking } \\
\text { groups of material interest to the home or host supervisor, and there is evidence that } \\
\text { these arrangements work in practice, where necessary. }\end{array}$ \\
\hline $\begin{array}{l}\text { Description and } \\
\text { findings re EC2 }\end{array}$ & $\begin{array}{l}\text { The legal framework (Article } 7.8 \text { of LABE) allows BdE to establish agreements with } \\
\text { foreign supervisors and central banks. There are equally specific provisions in RDL } \\
1298 / 1986 \text { (Article } 6.1 \text { ) regarding collaboration with supervisors in the EU. Moreover, } \\
\text { Law 13/1985 (Article } 10 \text { quáter) and Royal Decree } 216 / 2008 \text { (Article } 76 \text { ter) allows the } \\
\text { establishment by BdE of supervisory colleges. } \\
\text { The BdE has signed MoUs with supervisory authorities of the member countries of the } \\
\text { European Union (Germany, Belgium, France, Holland, Italy, Luxembourg, Portugal, } \\
\text { Romania), supervisors in Latin America (Colombia, Chile, Mexico, Peru, Brazil, } \\
\text { Argentina, Venezuela, Uruguay, and Puerto Rico), and with third countries (China, } \\
\text { U.S., and Andorra). } \\
\text { BdE reports information exchange is frequent and smooth, and the assessors have } \\
\text { confirmed with some host supervisors it is indeed so. }\end{array}$ \\
\hline EC3 & $\begin{array}{l}\text { The supervisor may provide confidential information to another domestic or foreign } \\
\text { financial sector supervisor. The supervisor is required to take reasonable steps to } \\
\text { ensure that any confidential information released to another supervisor will be used } \\
\text { only for supervisory purposes and will be treated as confidential by the receiving party. } \\
\text { The supervisor receiving confidential information from other supervisors is also } \\
\text { required to take reasonable steps to ensure that the confidential information will be } \\
\text { used only for supervisory purposes and will be treated as confidential. }\end{array}$ \\
\hline $\begin{array}{l}\text { Description and } \\
\text { findings re EC3 }\end{array}$ & $\begin{array}{l}\text { Article } 6.1 \text { of RDL } 1298 / 1986 \text { (as amended following the transposition of Directive } \\
2006 / 48 \text { ) establishes that in order to make agreements for international information } \\
\text { sharing with the competent authorities of non-EU third countries,, it is a requirement } \\
\text { that such authorities are subject to professional secrecy under conditions at least } \\
\text { comparable to those provided by Spanish law. The law then releases the BdE of its } \\
\text { confidentiality duty in order to provide supervisory information. Article } 6.5 \text { of RDL } \\
1298 / 1986 \text { specifically requires the recipients of information to take measures to } \\
\text { guarantee the conservation of confidentiality imposes a duty of professional secrecy } \\
\text { and limits its use to the legally established functions. The texts of the bilateral } \\
\text { supervisory MoUs agreed by BdE include confidentiality clauses so that the } \\
\text { information shared is deemed confidential and subject to professional secrecy } \\
\text { regulations and can only be used for lawful supervisory purposes. }\end{array}$ \\
\hline EC4 & $\begin{array}{l}\text { The supervisor is able to deny any demand (other than a court order or mandate form } \\
\text { a legislative body) for confidential information in its possession. }\end{array}$ \\
\hline $\begin{array}{l}\text { Description and } \\
\text { findings re EC4 }\end{array}$ & $\begin{array}{l}\text { RDL 1298/1986 (Article 6) establishes that all the information obtained by BdE's as a } \\
\text { result of the exercise of its functions is confidential. The exceptions are explicitly listed, } \\
\text { and include criminal courts, AML authorities, etc. LABE also states that when the } \\
\text { governor of BdE is reporting to the parliament, he/she can request a secret session so } \\
\text { that confidentiality is maintained. }\end{array}$ \\
\hline $\begin{array}{l}\text { Assessment of } \\
\text { principle } 1(6)\end{array}$ & Compliant \\
\hline
\end{tabular}




\begin{tabular}{|c|c|}
\hline Comments & \\
\hline Principle 2. & $\begin{array}{l}\text { The permissible activities of institutions that are licensed and subject to supervision as } \\
\text { banks must be clearly defined and the use of the word "Bank" in names should be } \\
\text { controlled as far as possible. }\end{array}$ \\
\hline \multicolumn{2}{|l|}{$\begin{array}{l}\text { Essential } \\
\text { criteria }\end{array}$} \\
\hline EC1 & The term "Bank" is clearly defined in laws or regulations. \\
\hline $\begin{array}{l}\text { Description and } \\
\text { findings re EC1 }\end{array}$ & $\begin{array}{l}\text { Laws and regulations clearly establish the terminology for each kind of credit } \\
\text { institution. RD Legislativo } 1298 / 1986 \text { establishes a generic definition of credit } \\
\text { institution as per EC regulation, Article } 37 \text { of LOB defines the term "bank;" Article } 21 \text { of } \\
\text { RDL defines savings banks (Cajas), Article } 3 \text { of Law } 13 / 1989 \text {, credit cooperatives, and } \\
\text { Article } 1.3 \text { of RD } 692 / 1996 \text {, special financial institutions. }\end{array}$ \\
\hline EC2 & $\begin{array}{l}\text { The permissible activities of institutions that are licensed and subject to supervision as } \\
\text { banks are clearly defined either by supervisors, or in laws or regulations. }\end{array}$ \\
\hline $\begin{array}{l}\text { Description and } \\
\text { findings re EC2 }\end{array}$ & The permissible activities of banks are clearly defined in Article 52 of LDI. \\
\hline EC3 & $\begin{array}{l}\text { The use of the word "bank" and any derivations such as "banking" in a name is limited } \\
\text { to licensed and supervised institutions in all circumstances where the general public } \\
\text { might otherwise be misled. }\end{array}$ \\
\hline $\begin{array}{l}\text { Description and } \\
\text { findings re EC3 }\end{array}$ & $\begin{array}{l}\text { Article } 28,29 \text {, and } 30 \text { of LDI reserve the denomination of "bank" and any related term } \\
\text { that may induce confusion to the licensed banks. Unlawful use of such denomination } \\
\text { is subject to BdE supervision and sanction. Public registries are forbidden to accept } \\
\text { registration of unlicensed institutions, and any unlawful registration is nullified. }\end{array}$ \\
\hline EC4 & $\begin{array}{l}\text { The taking of deposits from the public is generally reserved for institutions that are } \\
\text { licensed and subject to supervision as banks. }\end{array}$ \\
\hline $\begin{array}{l}\text { Description and } \\
\text { findings re EC4 }\end{array}$ & $\begin{array}{l}\text { The law reserves to credit institutions the taking of deposits from the public, in any } \\
\text { form. (arts. } 28 \text { and } 29 \text { of LDI and } 1 \text { of RDL 1298/1986). The BdE may prosecute and } \\
\text { sanction any infringement of this restriction. }\end{array}$ \\
\hline EC5 & $\begin{array}{l}\text { The supervisory or licensing authority publishes, and keeps current, a list of licensed } \\
\text { banks and branches of foreign banks operating within its jurisdiction. }\end{array}$ \\
\hline $\begin{array}{l}\text { Description and } \\
\text { findings re EC5 }\end{array}$ & $\begin{array}{l}\text { BdE is responsible for the official registry of credit institutions, which includes } \\
\text { branches of foreign banks. The registry is updated weekly and made public in BdE's } \\
\text { website. }\end{array}$ \\
\hline $\begin{array}{l}\text { Assessment of } \\
\text { Principle } 2\end{array}$ & Compliant \\
\hline \multicolumn{2}{|l|}{ Comments } \\
\hline Principle 3. & $\begin{array}{l}\text { Licensing criteria. The licensing authority must have the power to set criteria and } \\
\text { reject applications for establishments that do not meet the standards set. The licensing } \\
\text { process, at a minimum, should consist of an assessment of the ownership structure } \\
\text { and governance of the bank and its wider group, including the fitness and propriety of } \\
\text { Board members and senior management, its strategic and operating plan, internal } \\
\text { controls and risk management, and its projected financial condition, including its } \\
\text { capital base. Where the proposed owner or parent organization is a foreign bank, the } \\
\text { prior consent of its home country supervisor should be obtained. }\end{array}$ \\
\hline \multicolumn{2}{|l|}{$\begin{array}{l}\text { Essential } \\
\text { criteria }\end{array}$} \\
\hline EC1 & $\begin{array}{l}\text { The licensing authority could be the banking supervisor or another competent } \\
\text { authority. If the licensing authority and the supervisory authority are not the same, the } \\
\text { supervisor has the right to have its views considered on each specific application. In } \\
\text { addition, the licensing authority provides the supervisor with any information that may }\end{array}$ \\
\hline
\end{tabular}




\begin{tabular}{|c|c|}
\hline & be material to the supervision of the licensed institution. \\
\hline $\begin{array}{l}\text { Description and } \\
\text { findings re EC1 }\end{array}$ & $\begin{array}{l}\text { RD 1245/1995 (Article 1.1) and the Banking Law of } 1946 \text { determine that the licensing } \\
\text { authority is the MoE, based on a report by the BdE and the SEPBLAC. Procedures } \\
\text { and criteria for licensing are established in RD } 1245 / 1995 \text {. The applicants address the } \\
\text { Secretary General of the Treasury, in the MoE, and a preliminary assessment of the } \\
\text { compliance with the licensing criteria is made. The documents are then forwarded to } \\
\text { the BdE and Sepblac for their analysis. If the BdE needs additional information for its } \\
\text { assessment, it sends a letter to the MoE, who will then forward the request to the } \\
\text { applicants. Responses from applicants are equally transmitted to the BdE by the MoE. }\end{array}$ \\
\hline EC2 & $\begin{array}{l}\text { The licensing authority has the power to set criteria for licensing banks. These may be } \\
\text { based on criteria set in laws or regulations. }\end{array}$ \\
\hline $\begin{array}{l}\text { Description and } \\
\text { findings re EC2 }\end{array}$ & $\begin{array}{l}\text { The licensing authority does not have the power to set criteria for banks, as these are } \\
\text { established in Law. These are set in both Article } 43 \text { of LDI, and Articles } 1 \text { through } 9 \text { of } \\
\text { RD } 1245 / 1995 \text {. These include requirements on organization (sociedad anonima, } \\
\text { administrative council with at least five members), internal controls and accounting, } \\
\text { AML requirements, minimum capital, fit and proper requirements for main } \\
\text { shareholders and board members. }\end{array}$ \\
\hline EC3 & $\begin{array}{l}\text { The criteria for issuing licenses are consistent with those applied in ongoing } \\
\text { supervision. }\end{array}$ \\
\hline $\begin{array}{l}\text { Description and } \\
\text { findings re EC3 }\end{array}$ & $\begin{array}{l}\text { Article } 2.4 \text { of RD } 1245 / 1995 \text { determines that Banks must at all times comply with the } \\
\text { requirements for licensing. After authorization, the nomination of board members and } \\
\text { senior management does not require authorization but notification to the BdE. New } \\
\text { board members and senior management have to be registered in the BdE's "senior } \\
\text { managers register" (registro de altos cargos) and observance of fit and proper criteria } \\
\text { verified during ongoing supervision. Although the criteria for licensing should be } \\
\text { observed, the law establishes that the license can only be revoked in the case of } \\
\text { unsuitability of shareholders in exceptional cases, can be revoked in the case of } \\
\text { unsuitability of senior management only if the individuals do not leave their positions } \\
\text { within a month, and in the case of insufficient resources only if capital is below } \\
80 \text { percent of the minimum for longer than } 12 \text { months. The law also clarifies that senior } \\
\text { management cannot be considered unsuitable if, while in office, are sued or suspect of } \\
\text { the crimes mentioned in EC6. }\end{array}$ \\
\hline EC4 & $\begin{array}{l}\text { The licensing authority has the power to reject an application if the criteria are not } \\
\text { fulfilled or if the information provided is inadequate. }\end{array}$ \\
\hline $\begin{array}{l}\text { Description and } \\
\text { findings re EC4 }\end{array}$ & $\begin{array}{l}\text { The reasons for which a licensing application can be denied are also specified in the } \\
\text { mentioned laws. Specifically, Articles } 43.4 \text { and } 43.5 \text { determine that license can be } \\
\text { denied when minimum capital is not available, organizational structures and internal } \\
\text { controls are inadequate, when senior managers and board members (or those of the } \\
\text { parent company) are not fit and proper. License can also be denied if main } \\
\text { shareholders are not considered fit and proper. Article } 4 \text { of RD } 1245 / 1995 \text { states that } \\
\text { authorization can be denied if the requirements in Articles } 2 \text { and } 3 \text { are not observed, } \\
\text { and in particular if the significant shareholders are not considered fit and proper. } \\
\text { Article } 3 \text { includes the information that needs to be provided. }\end{array}$ \\
\hline EC5 & $\begin{array}{l}\text { The licensing authority determines that the proposed legal, managerial, operational } \\
\text { and ownership structures of the bank and its wider group will not hinder effective } \\
\text { supervision on both a solo and a consolidated basis. }\end{array}$ \\
\hline $\begin{array}{l}\text { Description and } \\
\text { findings re EC5 }\end{array}$ & $\begin{array}{l}\text { Article } 43.5 \text { of LDI, in particular item C, determines that the lack of transparency in the } \\
\text { group structure, or the existence of serious difficulties for the supervision or for } \\
\text { obtaining information on its activities, is a reason for the license to be denied. Article } 4 \\
\text { of RD } 1245 / 1995 \text { adds as a reason for denying authorization the possibility that }\end{array}$ \\
\hline
\end{tabular}




\begin{tabular}{|c|c|}
\hline & $\begin{array}{l}\text { supervision may be hindered by linkages between the entity and other individuals or } \\
\text { companies, or by legal or regulatory obstacles in the legal framework applicable to } \\
\text { such individuals or companies in other jurisdictions. }\end{array}$ \\
\hline EC6 & $\begin{array}{l}\text { The licensing authority identifies and determines the suitability of major shareholders, } \\
\text { including the ultimate beneficial owners, and others that may exert significant } \\
\text { influence. It also assesses the transparency of the ownership structure and the } \\
\text { sources of initial capital. }\end{array}$ \\
\hline $\begin{array}{l}\text { Description and } \\
\text { findings re EC6 }\end{array}$ & $\begin{array}{l}\text { The BdE report to the MoE includes the evaluation of the suitability of major } \\
\text { shareholders, as detailed in art. } 43.5 \text { of LDI and Articles } 2 \text { and } 4 \text { of RD } 1245 / 1995 . \\
\text { Suitability of shareholders includes the professional and commercial honor (will not be } \\
\text { considered honorable those who have been, in Spain or abroad, convicted of crime, or } \\
\text { declared incompetent for public service or financial management, such as those } \\
\text { bankrupt). Public entities and their related companies are automatically considered } \\
\text { honorable. Are also suitability criteria the financial means to conduct the business, and } \\
\text { the assurance that the entity will not incur risk derived from non-financial activities of } \\
\text { the shareholders. For structure requirements, see EC5. } \\
\text { On the identification of the ultimate beneficial owner, RD } 1245 / 1995 \text { (Article } 2.1 \text {.b) } \\
\text { determines that the capital of banks must be composed of nominative shares. } \\
\text { Shareholders that are legal entities must inform all holders of participations above } \\
5 \text { percent (such ultimate beneficiary owners may be themselves entities of dispersed } \\
\text { shareholder ownership). After authorization, under Article } 19 \text { of RD } 1245 / 1995 \text {, and } \\
\text { CBE } 1 / 2009, \text { there is the requirement that banks must send to BdE detailed } \\
\text { information on their societary composition, and inform whenever any share transaction } \\
\text { representing the acquisition of } 0.25 \text { percent or more has taken place. Sources of initial } \\
\text { capital are identified in business plans, and Sepblac conducts due diligence in this } \\
\text { regard, including contact with foreign AML/CFT authorities. }\end{array}$ \\
\hline EC7 & A minimum initial capital amount is stipulated for all banks. \\
\hline $\begin{array}{l}\text { Description and } \\
\text { findings re EC7 }\end{array}$ & $\begin{array}{l}\text { Article 2.1.b) RD } 1245 / 1995 \text { requires a minimum capital of at least } 18 \text { million Euros for } \\
\text { the licensing of a new bank. }\end{array}$ \\
\hline EC8 & $\begin{array}{l}\text { The licensing authority, at authorization, evaluates proposed directors and senior } \\
\text { management as to expertise and integrity (fit and proper test), and any potential for } \\
\text { conflicts of interest. The fit and proper criteria include: (i) skills and experience in } \\
\text { relevant financial operations commensurate with the intended activities of the bank; } \\
\text { and (ii) no record of criminal activities or adverse regulatory judgments that make a } \\
\text { person unfit to uphold important positions in a bank. }\end{array}$ \\
\hline $\begin{array}{l}\text { Description and } \\
\text { findings re EC8 }\end{array}$ & $\begin{array}{l}\text { RD 1245, Article 2, describes the requirements of senior management (consejo de } \\
\text { administración). It must be composed of at least five individuals, who meet the } \\
\text { suitability requirements described in EC6, and suitable professional experience (at } \\
\text { least five years experience in banking activities in senior/managerial positions, or } \\
\text { control and advisory to financial services, or equivalent experience in public or entities } \\
\text { of about the same size as the proposed new institution). }\end{array}$ \\
\hline EC9 & $\begin{array}{l}\text { The licensing authority reviews the proposed strategic and operating plans of the } \\
\text { bank. This includes determining that an appropriate system of corporate governance, } \\
\text { risk management and internal controls, including those related to the detection and } \\
\text { prevention of criminal activities, as well as the oversight of proposed outsourced } \\
\text { functions, will be in place. The operational structure is required to reflect the scope } \\
\text { and degree of sophistication of the proposed activities of the bank }\end{array}$ \\
\hline $\begin{array}{l}\text { Description and } \\
\text { findings re EC9 }\end{array}$ & $\begin{array}{l}\text { Articles 2.1.g) and i) and 3.b) of RD } 1245 / 1995 \text { require that applicants present their } \\
\text { plans for administrative organization, internal controls that are adequate to the prudent }\end{array}$ \\
\hline
\end{tabular}




\begin{tabular}{|c|c|}
\hline & $\begin{array}{l}\text { management of the institutions, and organization and control to detect and prevent } \\
\text { AML/FT activities. The plans must include the description of the intended operations of } \\
\text { the bank, the accounting procedures, and a realistic estimate of the business for the } \\
\text { first years of operation. }\end{array}$ \\
\hline EC10 & $\begin{array}{l}\text { The licensing authority reviews pro formal financial statements and projections for the } \\
\text { proposed bank. This includes an assessment of the adequacy of the financial strength } \\
\text { to support the proposed strategic plan as well as financial information on the principal } \\
\text { shareholder of the bank. }\end{array}$ \\
\hline $\begin{array}{l}\text { Description and } \\
\text { findings re EC10 }\end{array}$ & $\begin{array}{l}\text { See EC9. In addition, Article } 3 \text { of RD } 1245 / 1995 \text { require that shareholders provide } \\
\text { information on their financial history and situation, including audited accounts for the } \\
\text { previous two years if such shareholders are entities. }\end{array}$ \\
\hline EC11 & $\begin{array}{l}\text { In the case of foreign banks establishing a branch or subsidiary, before issuing a } \\
\text { license, the host supervisor establishes that no objection (or a statement of no } \\
\text { objection) from the home supervisor has been received. For purposes of the licensing } \\
\text { process, as well as ongoing supervision of cross-border banking operations in its } \\
\text { country, the host supervisor assesses whether the home supervisor practices global } \\
\text { consolidated supervision. }\end{array}$ \\
\hline $\begin{array}{l}\text { Description and } \\
\text { findings re EC11 }\end{array}$ & $\begin{array}{l}\text { See EC5. In addition, Article } 7 \text { of RD 12/45/1995 determines that before foreign banks } \\
\text { domiciled in EC countries are authorized to operate in Spain, BdE will contact the } \\
\text { home supervisor for its no-objection. For banks domiciled in non-EC countries, BdE } \\
\text { must require a guarantee that will cover the full operations of the new bank. In } \\
\text { addition, the opening of foreign branches will need to be authorized by the MoE } \\
\text { (Article 9) and the authorization from the home country supervisor for the } \\
\text { establishment of the branch needs to be presented. }\end{array}$ \\
\hline EC12 & $\begin{array}{l}\text { If the licensing, or supervisory, authority determines that the license was based on } \\
\text { false information, the license can be revoked. }\end{array}$ \\
\hline $\begin{array}{l}\text { Description and } \\
\text { findings re EC12 }\end{array}$ & $\begin{array}{l}\text { Article } 57 \text { bis of the Banking Law of } 1946 \text { determines that the authorization may be } \\
\text { revoked (by the council of ministers, see CP } 1.4 \text { ) if the information provided was false. }\end{array}$ \\
\hline EC13 & $\begin{array}{l}\text { The board, collectively, must have a sound knowledge of each of the types of activities } \\
\text { the bank intends to pursue and the associated risks. }\end{array}$ \\
\hline $\begin{array}{l}\text { Description and } \\
\text { findings re EC13 }\end{array}$ & $\begin{array}{l}\text { Article 2.1.f) of RD 1245/1995: determines that at least the majority of the board } \\
\text { satisfies the professional experience criteria described in EC8. }\end{array}$ \\
\hline \multicolumn{2}{|l|}{$\begin{array}{l}\text { Additional } \\
\text { criteria }\end{array}$} \\
\hline AC1 & $\begin{array}{l}\text { The assessment of the application includes the ability of the shareholder to supply } \\
\text { additional financial support, if needed. }\end{array}$ \\
\hline $\begin{array}{l}\text { Description and } \\
\text { findings re AC1 }\end{array}$ & $\begin{array}{l}\text { See EC9 and 10. The requirements include "sufficiency" of resources to cover the } \\
\text { commitments of the enterprise. There is no requirement to identify additional financial } \\
\text { support. }\end{array}$ \\
\hline AC2 & $\begin{array}{l}\text { The licensing or supervisory authority has policies and processes in place to monitor } \\
\text { the progress of new entrants in meeting their business and strategic goals, and to } \\
\text { determine that supervisory requirements outlined in the license approval are being } \\
\text { met. }\end{array}$ \\
\hline $\begin{array}{l}\text { Description and } \\
\text { findings re AC2 }\end{array}$ & $\begin{array}{l}\text { Article } 6 \text { of RD 1245/1995 establishes more intensive supervision and operational } \\
\text { restrictions (such as distribution of dividends) over the first } 5 \text { years of activities. In } \\
\text { particular, a major deviation from the business plan can lead to revocation of license. }\end{array}$ \\
\hline $\begin{array}{l}\text { Assessment of } \\
\text { Principle } 3\end{array}$ & Largely compliant \\
\hline Comments & $\begin{array}{l}\text { The licensing authority is the MoE, and the reasons for the denial of licenses, based } \\
\text { on BdE's report, are clearly stated in Law. There is no provision in the Law, however, }\end{array}$ \\
\hline
\end{tabular}




\begin{tabular}{|c|c|}
\hline & $\begin{array}{l}\text { that prevents the MoE from providing a license over the contrary opinion of BdE. } \\
\text { There is, therefore, no certainty that MoE's understanding of fit and proper, adequacy } \\
\text { of controls, and organizational structure, will coincide with the supervisory authority } \\
\text { and therefore not hinder effective supervision. The authorities report that this has } \\
\text { never been the case in practice, and the level of prescriptiveness in the legislation } \\
\text { makes this result unlikely. } \\
\text { The assessors did review four complete cases and it seems all due diligence has been } \\
\text { taken by the authorities. However, it seems that, in the ongoing reorganization process } \\
\text { of the Caja sector, suitability of shareholders and senior management has been } \\
\text { assumed, as the shareholders were authorized entities under CCAA suitability criteria. } \\
\text { It is recommended that, as the restructuring process continues, BdE ensures that } \\
\text { licensing criteria, in particular fit and proper requirements for senior management are } \\
\text { fully applied to the complex organizations that are being created. } \\
\text { It is also important to note that revocation of license derived for non-continued } \\
\text { compliance with licensing requirements seems to be extremely rare, although the legal } \\
\text { framework includes a provision that banks which do not conduct any banking } \\
\text { operation for over } 6 \text { months could have their license revoked (see CP 1.4). Interviews } \\
\text { with banks and other market participants indicate that in Spain several "nearly empty" } \\
\text { bank licenses exist. These are held by other banks, and such "nearly empty" banks } \\
\text { are kept in the organization for their franchise value and the operational cost of } \\
\text { licensing. It seems to be much simpler for market entrants to acquire such empty } \\
\text { banks than to start a new licensing procedure. However, the existence of such banks } \\
\text { complicates corporate structures and hampers transparency. }\end{array}$ \\
\hline Principle 4. & $\begin{array}{l}\text { Transfer of significant ownership. The supervisor has the power to review and reject } \\
\text { any proposals to transfer significant ownership or controlling interests held directly or } \\
\text { indirectly in existing banks to other parties. }\end{array}$ \\
\hline \multicolumn{2}{|l|}{$\begin{array}{l}\text { Essential } \\
\text { criteria }\end{array}$} \\
\hline EC1 & $\begin{array}{l}\text { Laws or regulations contain clear definitions of "significant" ownership and "controlling } \\
\text { interest." }\end{array}$ \\
\hline $\begin{array}{l}\text { Description and } \\
\text { findings re EC1 }\end{array}$ & $\begin{array}{l}\text { LDI (Article 56.1) clearly defines as significant a participation in a credit institution that } \\
\text { reaches, directly or indirectly, at least } 10 \text { percent of the capital or voting rights. } \\
\text { Holdings that do not reach this percentage but allow the holder to exercise notable } \\
\text { influence in the credit institution shall also be considered significant. RD } 1245 \\
\text { (Article 18) further clarifies that shares, contributions to capital, and voting rights that } \\
\text { are considered a significant holding include those acquired directly, those acquired } \\
\text { through companies that a natural person controls or has a relevant holding in, those } \\
\text { acquired by companies forming part of the same group, and those acquired by other } \\
\text { persons acting on behalf or in concert with the acquirer or with related companies } \\
\text { (including the cases where there is a voting agreement with a third party, and other } \\
\text { situations where indirect influence is detected). The definition of control is in the } \\
\text { Commercial Code of } 1885 \text { (Article } 42 \text { ), and is very broad, including the holding of the } \\
\text { majority of the voting rights, the capacity to nominate or destitute the majority of the } \\
\text { administration, and situations where these can be exercised indirectly. }\end{array}$ \\
\hline EC2 & $\begin{array}{l}\text { There are requirements to obtain supervisory approval or provide immediate } \\
\text { notification of proposed changes that would result in a change in ownership, including } \\
\text { beneficial ownership, or the exercise of voting rights over a particular threshold or } \\
\text { change in controlling interest. }\end{array}$ \\
\hline
\end{tabular}




\begin{tabular}{|c|c|}
\hline $\begin{array}{l}\text { Description and } \\
\text { findings re EC2 }\end{array}$ & $\begin{array}{l}\text { The law (LDI, Articles } 57 \text { and } 58 \text { ) establishes that any natural person or legal entity } \\
\text { intending to acquire a significant holding must inform the BdE prior to doing so. Prior } \\
\text { notification is also required if an increase in holdings reaches thresholds of } 20,30 \text {, and } \\
50 \text { percent or in any case when the acquisition implies a change in the controlling } \\
\text { interest in the institution. BdE has } 60 \text { working days to object to the change, otherwise } \\
\text { it is rendered approved. Banks must inform immediately when they become aware any } \\
\text { acquisition has breached the thresholds. }\end{array}$ \\
\hline EC3 & $\begin{array}{l}\text { The supervisor has the power to reject any proposal for a change in significant } \\
\text { ownership, including beneficial ownership, or controlling interest, or prevent the } \\
\text { exercise of voting rights in respect of such investments, if they do not meet criteria } \\
\text { comparable to those used for approving new banks. }\end{array}$ \\
\hline $\begin{array}{l}\text { Description and } \\
\text { findings re EC3 }\end{array}$ & $\begin{array}{l}\text { See EC2. BdE has } 60 \text { working days to refuse the intended acquisition, based on an } \\
\text { evaluation of suitability, financial soundness, and potential influence of the acquirer in } \\
\text { the entity. BdE consults with Sepblac at all cases, and with the foreign supervisor if the } \\
\text { potential acquirer is a foreign financial institution. The analysis includes an evaluation } \\
\text { of fit and proper, including criminal activities, of the proposed shareholders, and of } \\
\text { proposed senior management and board members, if the case. Acquisition of } \\
\text { significant holding that occur without BdE authorization, voting rights are suspended, } \\
\text { and any decision taken in the interim impugnable. BdE may intervene, replace senior } \\
\text { management, and initiate sanctioning procedures. If the influence of the significant } \\
\text { participation in the bank is considered materially detrimental to the financial } \\
\text { soundness of the bank, the MoE may decide, exceptionally, to revoke the license. }\end{array}$ \\
\hline EC4 & $\begin{array}{l}\text { The supervisor obtains from banks, through periodic reporting or on-site examinations, } \\
\text { the names and holdings of all significant shareholders or those that exert controlling } \\
\text { influence, including the identities of beneficial owners of shares being held by } \\
\text { nominees, custodians and through vehicles which might be used to disguise } \\
\text { ownership. }\end{array}$ \\
\hline $\begin{array}{l}\text { Description and } \\
\text { findings re EC4 }\end{array}$ & $\begin{array}{l}\text { RD } 1245 / 1995 \text { (Article } 2.1 . b \text { ) determines that the capital of banks must be composed } \\
\text { of nominative shares. Under Article } 19 \text {, and CBE } 1 / 2009 \text {, there is the requirement that } \\
\text { banks must send to BdE detailed information on their societary composition, and } \\
\text { inform whenever any share transaction representing the acquisition of } 0.25 \text { percent or } \\
\text { more has taken place. A quarterly supervisory return detailing the societary structure } \\
\text { is sent, which includes indirect ownership (in which case the chain of ownership to the } \\
\text { final owner must be detailed (Circular } 5 / 2010 \text { ). Such ultimate beneficiary owners may } \\
\text { be themselves entities of dispersed shareholder ownership. } \\
\text { Article } 20 \text { of RD } 1245 / 1995 \text { also mandates that information on the societary capital } \\
\text { structure be provided in the annual reports, in particular, individual information of } \\
\text { holdings representing } 5 \text { percent or more of the voting rights. }\end{array}$ \\
\hline EC5 & $\begin{array}{l}\text { The supervisor has the power to take appropriate action to modify, reverse or } \\
\text { otherwise address a change of control that has taken place without the necessary } \\
\text { notification to or approval from the supervisor. }\end{array}$ \\
\hline $\begin{array}{l}\text { Description and } \\
\text { findings re EC5 }\end{array}$ & See EC3. \\
\hline \multicolumn{2}{|l|}{$\begin{array}{l}\text { Additional } \\
\text { criteria }\end{array}$} \\
\hline AC1 & $\begin{array}{l}\text { Laws and regulations provide, or the supervisor ensures, that banks must notify the } \\
\text { supervisor as soon as they become aware of any material information which may } \\
\text { negatively affect the suitability of a major shareholder. }\end{array}$ \\
\hline $\begin{array}{l}\text { Description and } \\
\text { findings re } A C 1\end{array}$ & $\begin{array}{l}\text { It is considered a very serious infraction (see CP 23) to risk the prudent management } \\
\text { of a bank through the influence of a significant holding. Banks have } 10 \text { days to inform }\end{array}$ \\
\hline
\end{tabular}




\begin{tabular}{|c|c|}
\hline & BdE of any transfer of ownership representing 1 percent or more of the social capital. \\
\hline $\begin{array}{l}\text { Assessment of } \\
\text { Principle } 4\end{array}$ & Largely Compliant \\
\hline Comments & $\begin{array}{l}122 \text { requests for transferring significant participation have been received in the past } \\
\text { five years, all but one have been approved. Each application may involve one or more } \\
\text { interested parties. Some of these are reorganization within the entity, including } \\
\text { creation of SPVs (Law } 19 / 1992 \text { and RD 926/1998) and the segregation of financial } \\
\text { activities of Cajas into Banks. The denied application was related to AML/FT } \\
\text { restrictions and structural hindrance to consolidated supervision concerns. The } \\
\text { assessors were given access to one complete case and also viewed the database } \\
\text { derived from the supervisory returns. Ultimate beneficiary owners may be themselves } \\
\text { entities of dispersed shareholder ownership. } \\
\text { The peculiar situation of new commercial banks created as the result of the reform of } \\
\text { the Cajas should be carefully followed by authorities, insofar as the new shareholder } \\
\text { entities (no longer conducting banking business) have no identifiable ownership and } \\
\text { frequently have close links to the local political environment given their social services } \\
\text { objectives. This situation has the potential to create detrimental influence over the } \\
\text { bank's operations and soundness. Supervision of such institutions need to be tailored } \\
\text { to these special characteristics and the BdE/MoE should be ready to use sanctioning } \\
\text { powers under LDI Article } 4 \text { (II). In the course of this assessment the government was } \\
\text { preparing changes in the legal framework for the governance of such entities. The } \\
\text { next BCP assessment update should include this CP in the review. }\end{array}$ \\
\hline Principle 5. & $\begin{array}{l}\text { Major acquisitions. The supervisor has the power to review major acquisitions or } \\
\text { investments by a bank, against prescribed criteria, including the establishment of } \\
\text { cross-border operations, and confirming that corporate affiliations or structures do not } \\
\text { expose the bank to undue risks or hinder effective supervision. }\end{array}$ \\
\hline \multicolumn{2}{|l|}{$\begin{array}{l}\text { Essential } \\
\text { criteria }\end{array}$} \\
\hline EC1 & $\begin{array}{l}\text { Laws or regulations clearly define what types and amounts (absolute and/or in relation } \\
\text { to a bank's capital) of acquisitions and investments need prior supervisory approval. }\end{array}$ \\
\hline $\begin{array}{l}\text { Description and } \\
\text { findings re EC1 }\end{array}$ & $\begin{array}{l}\text { The law clearly defines situations when investments need supervisory approval: } \\
\text { a) Any significant participation in a credit institution in Spain or abroad (see CP 4). } \\
\text { b) Any branch or subsidiary abroad (LDI Article } 30 \text { bis). } \\
\text { For other cases, the legal framework establishes limits instead of an authorization } \\
\text { procedure. Excesses over such limits must be deducted from regulatory capital: } \\
\text { a) Acquisitions are subject to large exposures limits-investments are added to loan } \\
\text { exposures for the calculation of the } 25 \text { percent large exposure limit (see CP 10). } \\
\text { b) The higher of the following must be deducted: (a) the total amount of qualifying } \\
\text { holdings } 10 \text { in non-financial companies for the part that it exceeds } 60 \text { percent of } \\
\text { the institution or group's regulatory capital; (b) the sum of qualifying holdings in } \\
\text { each non-financial company for the part of each holding that exceeds } 15 \text { percent } \\
\text { of the institution's regulatory capital.(Article } 10 \text { Law } 13 / 1985 \text {, Article } 16 \text { RD } \\
216 / 2008 ; \text { norma } 10 \text { CBE } 3 / 2008 \text { )Must be deducted from regulatory capital the } \\
\text { holdings in financial institutions that are consolidated on the basis of their activity } \\
\text { but are not integrated into the consolidated group and not listed as insurance } \\
\text { companies, when the holding exceeds } 10 \text { percent of the capital of the respective } \\
\text { institution or group, or the sum of all holdings that are equal to or less than }\end{array}$ \\
\hline
\end{tabular}




\begin{tabular}{|c|c|}
\hline & $\begin{array}{l}10 \text { percent of the capital of said institutions, for the part that exceeds } 10 \text { percent of } \\
\text { the holder's or its group's own funds. Must be deducted from regulatory capital the } \\
\text { investments in insurance companies which exceed } 20 \text { percent of regulatory } \\
\text { capital. (Article } 13 . R D 216 / 2008 \text {, and } 9^{a} \text {. CBE } 3 / 2008 \text { ). }\end{array}$ \\
\hline EC2 & Laws or regulations provide criteria by which to judge individual proposals. \\
\hline $\begin{array}{l}\text { Description and } \\
\text { findings re EC2 }\end{array}$ & $\begin{array}{l}\text { For the cases where authorization is prescribed, the law establishes the criteria for the } \\
\text { denial: Article } 13 \text { RD } 1245 / 1995 \text { for opening foreign branches and subsidiaries, } \\
\text { Article } 30 \text { bis. } 5 \text { of LDI for acquisition of Spanish credit entities (see CP } 3 \text { and } 4 \text { ) }\end{array}$ \\
\hline EC3 & $\begin{array}{l}\text { Consistent with licensing requirements, among the objective criteria that the } \\
\text { supervisor uses is that any new acquisitions and investments do not expose the bank } \\
\text { to undue risks or hinder effective supervision. The supervisor can prohibit banks from } \\
\text { making major acquisitions / investments (including the establishment of foreign } \\
\text { branches or subsidiaries) in countries with secrecy laws or other regulations } \\
\text { prohibiting information flows deemed necessary for adequate consolidated } \\
\text { supervision. }\end{array}$ \\
\hline $\begin{array}{l}\text { Description and } \\
\text { findings re EC3 }\end{array}$ & $\begin{array}{l}\text { Among the reasons listed in law for denying authorization are the assessment by BdE } \\
\text { that, due to the credit institution's financial position or management capacity, the } \\
\text { project could have a negative effect on safety and soundness, that the BdE cannot } \\
\text { ensure effective supervision of the group on a consolidated basis, or when the activity } \\
\text { of said institution is not subject to effective supervision by the national supervisory } \\
\text { authority. Article } 17 \text { of Law } 124 / 1995 \text { also determines that applications need to provide } \\
\text { all host country regulation in terms of AML. }\end{array}$ \\
\hline EC4 & $\begin{array}{l}\text { The supervisor determines that the bank has, from the outset, adequate financial and } \\
\text { organizational resources to handle the acquisition/investment. }\end{array}$ \\
\hline $\begin{array}{l}\text { Description and } \\
\text { findings re EC4 }\end{array}$ & $\begin{array}{l}\text { The compliance with licensing and prudential requirements is necessary to initiate the } \\
\text { authorization process. For the cases when no authorization is needed, the limits and } \\
\text { deductions to capital in essence circumscribe major acquisitions to institutions with } \\
\text { adequate financial resources. Organizational capacity and internal controls are } \\
\text { assessed on ongoing supervision (see CP } 19 \text { and 20). }\end{array}$ \\
\hline EC5 & $\begin{array}{l}\text { Laws and regulations clearly define for which cases notification after the acquisition or } \\
\text { investment is sufficient. Such cases should primarily refer to activities closely related } \\
\text { to banking and the investment being small relative to the bank's capital. }\end{array}$ \\
\hline $\begin{array}{l}\text { Description and } \\
\text { findings re EC5 }\end{array}$ & $\begin{array}{l}\text { See EC1. All acquisitions of significant holdings in financial companies need } \\
\text { authorization. The acquisition of non-financial holdings is not subject to authorization } \\
\text { but to limits and to reporting only (CBE 5/95, CBE 4/2004, and CBE } 3 / 2008 \text { ). } \\
\text { Reporting provided to the BdE is extensive and includes information on such } \\
\text { exposures (see CP } 10 \text { and CP 21). }\end{array}$ \\
\hline EC6 & $\begin{array}{l}\text { The supervisor is aware of the risks that non-banking activities can pose to a banking } \\
\text { group, and has the means to take action to mitigate those risks. }\end{array}$ \\
\hline $\begin{array}{l}\text { Description and } \\
\text { findings re EC6 }\end{array}$ & $\begin{array}{l}\text { See EC1. There are limits to participation in non-financial business, and excesses are } \\
\text { deducted from capital. In addition, at any time during supervision the BdE can restrict } \\
\text { activities and operations and require the reduction of exposure to risk if the proposed } \\
\text { activities are deemed to be detrimental to soundness of the bank. (Article } 113 \text { of Law } \\
\text { 13/1985). }\end{array}$ \\
\hline \multicolumn{2}{|l|}{$\begin{array}{l}\text { Additional } \\
\text { criteria }\end{array}$} \\
\hline AC1 & $\begin{array}{l}\text { When a bank wishes to acquire a significant holding in a financial institution in another } \\
\text { country, the supervisor should take into consideration the quality of supervision in that }\end{array}$ \\
\hline
\end{tabular}




\begin{tabular}{|c|c|}
\hline & country and its own ability to exercise supervision on a consolidated basis. \\
\hline $\begin{array}{l}\text { Description and } \\
\text { findings re } A C 1\end{array}$ & See EC3. \\
\hline $\begin{array}{l}\text { Assessment re } \\
\text { Principle } 5\end{array}$ & Compliant \\
\hline Comments & $\begin{array}{l}\text { The assessors were given access to supervisory files and reports relative to this CP. } \\
\text { The cases where no authorization is required are limited in materiality due to the } \\
\text { country's option for limits and deductions and seem to be adequately monitored by } \\
\text { ongoing supervision. Existing participation in industrial businesses, which are a source } \\
\text { of concern, are under the thresholds established by law and exposures continuously } \\
\text { monitored. More than a hindrance to supervision, concerns regarding such } \\
\text { participations are higher in what they involve related lending. In this assessment, } \\
\text { these concerns are covered within CP } 11 \text {. }\end{array}$ \\
\hline Principle 6. & $\begin{array}{l}\text { Capital adequacy. Supervisors must set prudent and appropriate minimum capital } \\
\text { adequacy requirements for banks that reflect the risks that the bank undertakes, and } \\
\text { must define the components of capital, bearing in mind its ability to absorb losses. At } \\
\text { least for internationally active banks, these requirements must not be less than those } \\
\text { established in the applicable Basel requirement. }\end{array}$ \\
\hline \multicolumn{2}{|l|}{$\begin{array}{l}\text { Essential } \\
\text { criteria }\end{array}$} \\
\hline EC1 & $\begin{array}{l}\text { Laws and regulations require all banks to calculate and consistently maintain a } \\
\text { minimum CAR. Laws, regulations or the supervisor define the components of capital, } \\
\text { ensuring that emphasis is given to those elements of capital available to absorb } \\
\text { losses. }\end{array}$ \\
\hline $\begin{array}{l}\text { Description and } \\
\text { findings re EC1 }\end{array}$ & $\begin{array}{l}\text { Laws and regulations require all banks to calculate a minimum CAR (see EC2), and } \\
\text { the components of capital are also defined in Laws. Law } 13 / 1985 \text { defines the types of } \\
\text { risks, options for calculating the capital requirements, establishes compliance on } \\
\text { consolidated basis and the deductions from capital. The minimum CAR ratio is } \\
\text { established by RD } 216 / 2008 \text { (Article } 17 \text { ). } \\
\text { There are currently two definitions of capital over which capital adequacy is required. } \\
\text { The regulatory capital (recursos proprios) described by Chapter II of RD } 216 / 2008 \\
\text { is closer to Basel II and general Capital Requirements Directive (CRD) framework, } \\
\text { where the components are distributed in three tiers according to their loss absorption } \\
\text { (Tier } 3 \text { is not in use). Tier } 1 \text { (recursos propios básicos) is composed of ordinary } \\
\text { shares, preferred shares (limited to } 30 \text { percent of Tier } 1 \text { and subject to some loss } \\
\text { absorption features closer to Basel III requirements }{ }^{10} \text { ), reserves, minus intangibles. } \\
\text { Tier } 2 \text { is composed of subordinated debt (limited to } 50 \text { percent of Tier } 1 \text { ), general } \\
\text { provisions (limited to } 1.25 \text { percent of RWA) or excess provisions over expected loss, } \\
\text { for IRB banks (limited to } 0.6 \text { percent of RWA). Common equity plus reserves, minus } \\
\text { losses, intangibles and own shares must be at least } 50 \text { percent of Tier } 1 \text { (this is the }\end{array}$ \\
\hline
\end{tabular}

\footnotetext{
${ }^{10}$ Some of the features are the suspension or cancellation of payments (non-cumulative) if the individual institution or the consolidated group is not compliant with capital requirements or upon BdEs decision. Payments can be replaced by conversion into common equity. In addition, it capital adequacy rations start to fall significantly, or the institutions start to present significant losses - even if rations are still complied with - the preferred shares must have a mechanism of loss absorption either through conversion into common shares or reduction of the nominal value of the debt.
} 


\begin{tabular}{|c|c|}
\hline & $\begin{array}{l}\text { concept of "capital predominante). In addition, in the framework of restructuring of } \\
\text { the savings banks, it has been established (RD } 2 / 2011 \text { ) that all capital injections by } \\
\text { FROB, in any format, can be used for Tier } 1 \text { and no limits apply. } \\
\text { The same RD also created a new definition of capital, which coexists with the } \\
\text { definition of regulatory capital. Banks are to comply with certain requirements based } \\
\text { on both. The "capital principal" is considered a step towards the Basel III Common } \\
\text { Equity capital definition, but will need to be further adjusted when Basel III is } \\
\text { implemented. Capital principal is similar to the capital predominante, but includes the } \\
\text { adjustments for gains and losses on the available-for-sale securities, and accepts up } \\
\text { to } 25 \text { percent of mandatory convertible instruments (ManCos). Acceptable } \\
\text { ManCos's date of mandatory conversion into common equity needs to be before } \\
\text { December } 31,2018 \text { (it was } 2014 \text {, extended to } 2018 \text { by RDL } 2 / 2012 \text { ), the conversion } \\
\text { terms need to have been defined at issuance, payments can be suspended by issuer } \\
\text { in case of solvency concerns. Trading of such instruments need to be according to } \\
\text { CNMV rules, with additional requirements in case of sale to in particular if sold to retail } \\
\text { investor ICAAP target capital ratio must be based on the definition of capital principal. }\end{array}$ \\
\hline EC2 & $\begin{array}{l}\text { At least for internationally active banks, the definition of capital, the method of } \\
\text { calculation and the ratio required shall not be lower than those established in the } \\
\text { applicable Basel requirement. }\end{array}$ \\
\hline $\begin{array}{l}\text { Description and } \\
\text { findings re EC2 }\end{array}$ & $\begin{array}{l}\text { Regulations apply to both internationally active and domestic banks. For the definition } \\
\text { of capital, see EC1. To calculate the CAR, laws and regulations detail the application } \\
\text { of Basel II standardized and advanced approaches. (Law } 13 / 1985, \text { RD } 216 / 2008, \text { CBE } \\
3 / 2008 \text { ). RWAs that differ from the Basel II framework are relative to residential real } \\
\text { estate exposures, where the reduced RW of } 35 \text { percent is not allowed for exposures } \\
\text { where the LTV exceeds } 80 \text { percent. When the value of collateral is between } \\
80 \text { percent and } 95 \text { percent of the loan, a } 100 \text { percent RW is applicable. Beyond that, } \\
150 \text { percent is applicable (such higher RW are applicable on the part of the exposure } \\
\text { that exceeds the value of the collateral). On the other hand, overdue exposures can } \\
\text { receive a RW of } 100 \text { percent when specific provisions are below } 20 \text { percent of the } \\
\text { exposure net of provisions. } \\
\text { The minimum CAR ratio established by RD } 216 / 2008 \text { is } 8 \text { percent, calculated over } \\
\text { "recursos proprios" (regulatory capital). However, RDL } 2 / 2011 \text { also created mandatory } \\
\text { CARs calculated over "capital principal" (CARcp), which is also } 8 \text { percent. Credit } \\
\text { institutions whose wholesale funding is above } 20 \text { percent of deposits, however, need } \\
\text { to have a CARcp of } 10 \text { percent. Part of this capital requirement can be considered a } \\
\text { capital conservation buffer, in the sense that banks that are } 20 \text { percent below the } \\
\text { established CARcp are subject to restrictions on the allocation of profits. } \\
\text { In addition, in the course of this assessment, the government issued new measures to } \\
\text { strengthen the financial sector. One of the measures (RDL } 2 / 2012 \text { ) is an additional } \\
\text { requirement of capital principal of } 20 \text { percent on land-related and } 15 \text { percent for } \\
\text { "housing under development" exposures which are not overdue but considered } \\
\text { problematic (see CP } 9 \text { ). These additional requirements are to be calculated on top of } \\
\text { current CARcp requirements. } \\
\text { In practice, internationally active banks in Spain are subject to yet another capital } \\
\text { requirement. In October } 2011 \text { the EBA issued a "capital package" to provide an }\end{array}$ \\
\hline
\end{tabular}




\begin{tabular}{|c|c|}
\hline & $\begin{array}{l}\text { additional capital buffer for the European banking system, in particular by building up a } \\
\text { temporary capital buffer against sovereign debt exposures to reflect current market } \\
\text { prices. Banks are required to establish a buffer such that the Core Tier } 1 \text { capital ratio } \\
\text { reaches } 9 \text { percent by end of June } 2012 \text { (this is based on EBA ad-hoc definition of } \\
\text { Core Tier 1, which is different from capital principal and Basel III Common Equity } \\
\text { capital). }\end{array}$ \\
\hline EC3 & $\begin{array}{l}\text { The supervisor has the power to impose a specific capital charge and/or limits on all } \\
\text { material risk exposures. }\end{array}$ \\
\hline $\begin{array}{l}\text { Description and } \\
\text { findings re EC3 }\end{array}$ & $\begin{array}{l}\text { According to Article } 6 \text { of Law 13/1985, the BdE is responsible for the determination of } \\
\text { the calculation of capital requirements, risk weights for different transactions, and } \\
\text { additional requirements according to the risk profile of the bank and risk mitigation } \\
\text { accepted. The BdE is also entitled to impose, in a manner commensurate with the } \\
\text { risks and types of credit institutions, maximum ceilings on investments in property or } \\
\text { other fixed assets; on shares and other equities, on assets, liabilities or foreign } \\
\text { currency positions; on the risks that may be incurred with a single person, institution or } \\
\text { economic group, and on any transaction or position that may entail risks to the } \\
\text { solvency. The main components of Pillar } 1 \text { capital requirements are established in the } \\
\text { same law: credit risk, market risk, and operational risk. }\end{array}$ \\
\hline EC4 & $\begin{array}{l}\text { The required capital ratio reflects the risk profile of individual banks. Both on-balance } \\
\text { sheet and off-balance sheet risks are included. }\end{array}$ \\
\hline $\begin{array}{l}\text { Description and } \\
\text { findings re EC4 }\end{array}$ & $\begin{array}{l}\text { Capital requirements are detailed in Royal Decree } 216 / 2008 \text { and Circular } 3 / 2008 \text { and } \\
\text { include both on- and off-balance sheet risks. On imposing a capital ratio that reflects } \\
\text { the risk profile of individual banks, besides the powers under Articles } 6 \text { and } 11 \text { of Law } \\
13 / 1985 \text { described in EC3, RD } 2 / 2011 \text { establishes that BdE may require banks, on } \\
\text { both solo and consolidated basis, a level of CARcp above the regulatory levels if the } \\
\text { institution fails to cover the worst scenario in a systemic stress test. BdE has also } \\
\text { published guidance on both ICAAP and SREP for the implementation of Pillar } 2 \text { (see } \\
\text { CP } 7 \text { ). In practice, for instance, EBA additional capital requirements have been } \\
\text { enforced through Pillar } 2 \text {. }\end{array}$ \\
\hline EC5 & $\begin{array}{l}\text { Capital adequacy requirements take into account the conditions under which the } \\
\text { banking system operates. Consequently, laws and regulations in a particular } \\
\text { jurisdiction may set higher capital adequacy standards than the applicable Basel } \\
\text { requirements. }\end{array}$ \\
\hline $\begin{array}{l}\text { Description and } \\
\text { findings re EC5 }\end{array}$ & See EC2 above, in particular with respect to RDL 2/2011 and RDL 2/2012. \\
\hline EC6 & $\begin{array}{l}\text { Laws or regulations clearly give the supervisor authority to take measures should a } \\
\text { bank fall below the minimum capital ratio. }\end{array}$ \\
\hline $\begin{array}{l}\text { Description and } \\
\text { findings re EC6 }\end{array}$ & $\begin{array}{l}\text { Law } 13 / 1985 \text { (Article 11) determines that failure to comply with minimum requirements } \\
\text { (capital as well as internal controls), BdE can i) require more capital than the } \\
\text { minimum, ii) It may restrict or limit business, operations or the network of the } \\
\text { institutions, and apply the sanctions of LDI. LDI establishes as very serious infractions } \\
\text { (see CP 23) being below the minimum absolute authorized capital for more than six } \\
\text { months, or falling below } 80 \text { percent of established individual CAR. In terms of capital } \\
\text { principal as mentioned in EC2, banks and banking groups which fall below } 80 \text { percent } \\
\text { of CARcp are subject to restrictions on the distribution of dividends, remuneration of } \\
\text { executives, allocation of funds for social/benemerit institutions, suspension of } \\
\text { payments of subordinated debt and preferentes (and are as well as subject to "very } \\
\text { serious" infraction sanctions). }\end{array}$ \\
\hline EC7 & $\begin{array}{l}\text { Where the supervisor permits banks to use internal assessments of risk as inputs to } \\
\text { the calculation of regulatory capital, such assessments must adhere to rigorous }\end{array}$ \\
\hline
\end{tabular}




\begin{tabular}{|c|c|}
\hline & $\begin{array}{l}\text { qualifying standards and be subject to the approval of the supervisor. If banks do not } \\
\text { continue to meet these qualifying standards on an ongoing basis, the supervisor may } \\
\text { revoke its approval of the internal assessments. }\end{array}$ \\
\hline $\begin{array}{l}\text { Description and } \\
\text { findings re AC7 }\end{array}$ & $\begin{array}{l}\text { Spain has implemented Basel II and institutions may be allowed to use internal } \\
\text { measurements for the calculation of credit, market and operational risk (RD 216/2008) } \\
\text { upon authorization by BdE. The Law requires BdE to ascertain compliance with } \\
\text { several requirements, including that the internal systems used to calculate capital are } \\
\text { integrated with the risk management of the institution. The procedures for requesting } \\
\text { authorization to use internal models to the BdE and criteria that BdE will use in the } \\
\text { assessment are public available. } \\
\text { (http://www.bde.es/webbde/es/supervision/funciones/implantacion.html). Qualitative } \\
\text { and quantitative requirements are those established by Directives } 2006 / 48 / E C \text { and } \\
2006 / 49 / E C \text { of the European Parliament. In sum, BdE's validation process starts with } \\
\text { the Implementation Plan, which collects information on the consolidated group, the } \\
\text { Files for each specific risk, and a Model Dossier on each specific model. Validation } \\
\text { process is divided in five stages, and involves not only the bank's inspection teams but } \\
\text { specialized technical groups (IT and risk modeling): methodology and documentation, } \\
\text { data, quantitative procedures, qualitative procedures and control environment, and } \\
\text { technological environment. Monitoring of capital calculation requirements and } \\
\text { practices is part of the ongoing supervision work. When banks cease meeting the } \\
\text { qualifying requirements, for any reason, BdE may revoke its authorization for the use } \\
\text { of internal capital measurement models (and impose sanctions). }\end{array}$ \\
\hline \multicolumn{2}{|l|}{$\begin{array}{l}\text { Additional } \\
\text { criteria }\end{array}$} \\
\hline AC1 & $\begin{array}{l}\text { For non-internationally active banks, the definition of capital, the method of calculation } \\
\text { and the capital required are broadly consistent with the principles of the applicable } \\
\text { Basel requirements relevant to internationally active banks. }\end{array}$ \\
\hline $\begin{array}{l}\text { Description and } \\
\text { findings re } A C 1\end{array}$ & $\begin{array}{l}\text { See EC1 and } 2 . \text { Requirements apply equally to internationally active and domestic } \\
\text { banks. }\end{array}$ \\
\hline AC2 & $\begin{array}{l}\text { For non-internationally active banks and their holding companies, CARs are calculated } \\
\text { and applied in a manner generally consistent with the applicable Basel requirement, } \\
\text { as set forth in the footnote to the Principle. }\end{array}$ \\
\hline $\begin{array}{l}\text { Description and } \\
\text { findings re AC2 }\end{array}$ & $\begin{array}{l}\text { Capital requirements are applied on both solo and consolidated basis. For } \\
\text { conglomerates, Spain applies the Conglomerates directive, which has been } \\
\text { transposed to internal law in RD } 1332 / 2005 \text {. }\end{array}$ \\
\hline AC3 & $\begin{array}{l}\text { The supervisor has the power to require banks to adopt a forward-looking approach to } \\
\text { capital management and set capital levels in anticipation of possible events or } \\
\text { changes in market conditions that could have an adverse effect. }\end{array}$ \\
\hline $\begin{array}{l}\text { Description and } \\
\text { findings re AC3 }\end{array}$ & $\begin{array}{l}\text { RD } 216 / 2008 \text { and CBE } 3 / 2008 \text { impose the ICAAP process for all banks. That includes } \\
\text { a forward looking approach to capital planning, setting a target capital ratio for the next } \\
\text { three years. In addition, RDL } 2 / 2011 \text { establishes that BdE may require banks, on both } \\
\text { solo and consolidated basis, a level of CARcp above the regulatory levels if the } \\
\text { institution fails to cover the worst scenario in a systemic stress test. }\end{array}$ \\
\hline AC4 & $\begin{array}{l}\text { The supervisor requires adequate distribution of capital within different entities of the } \\
\text { banking group according to the allocation of risks. }\end{array}$ \\
\hline $\begin{array}{l}\text { Description and } \\
\text { findings re AC4 }\end{array}$ & $\begin{array}{l}\text { Circular } 3 / 2008 \text { establishes that the ICAAP process must include an assessment of } \\
\text { the adequacy of capital distribution among the different entities of the group according } \\
\text { to their risk (Rule 107). BdE may take any necessary measure to guarantee that the } \\
\text { distribution of risks and capital among group entities is adequate (Rule } 5 \text { of CBE }\end{array}$ \\
\hline
\end{tabular}




\begin{tabular}{|c|c|}
\hline & 2/2008 and Article 9 of law 13/1985). \\
\hline AC5 & $\begin{array}{l}\text { The supervisor may require an individual bank or banking group to maintain capital } \\
\text { above the minimum to ensure that individual banks or banking groups are operating } \\
\text { with the appropriate level of capital. }\end{array}$ \\
\hline $\begin{array}{l}\text { Description and } \\
\text { findings re AC5 }\end{array}$ & See EC4 and AC4. \\
\hline $\begin{array}{l}\text { Assessment re } \\
\text { principle } 6\end{array}$ & Compliant \\
\hline Comments & $\begin{array}{l}\text { In Spain, the validation process of advanced approaches seems to be rigorous. } \\
\text { Interviews with the industry corroborate the depth and scope of the validation process, } \\
\text { and international banking groups compared the follow up and monitoring of use of } \\
\text { models stricter by the BdE than other of their international supervisors }{ }^{11} \text {. Assessors } \\
\text { were given access to review the proceedings for validation and authorization of } \\
\text { internal models, including the Files and Dossiers. Currently, } 4 \text { banking groups are } \\
\text { authorized to use advanced approaches for market risk, } 8 \text { for IRB and only one for } \\
\text { advance measurement approach (AMA). } \\
\text { The co-existence of different capital definitions in the regulatory framework is } \\
\text { detrimental to the clarity of requirements and comparability of different institutions and } \\
\text { metrics. BdE is to apply Basel III definitions starting in } 2013 \text {, according to the BCBS } \\
\text { and CRD schedule. It is recommended that authorities seek to use the Basel III } \\
\text { definition of Common Equity capital to replace Capital principal, so that international } \\
\text { comparability and transparency can be enhanced. } \\
\text { It is understood that FROB injections would be grandfathered under Basel III, and } \\
\text { gradually phased out. Future BCP assessment updates should include a review on } \\
\text { how Basel III capital definition has been implemented. }\end{array}$ \\
\hline Principle 7. & $\begin{array}{l}\text { Risk management process. Supervisors must be satisfied that banks and banking } \\
\text { groups have in place a comprehensive risk management process (including Board and } \\
\text { senior management oversight) to identify, evaluate, monitor and control or mitigate all } \\
\text { material risks and to assess their overall capital adequacy in relation to their risk } \\
\text { profile. These processes should be commensurate with the size and complexity of the } \\
\text { institution. }\end{array}$ \\
\hline \multicolumn{2}{|l|}{$\begin{array}{l}\text { Essential } \\
\text { criteria }\end{array}$} \\
\hline EC1 & $\begin{array}{l}\text { Individual banks and banking groups are required to have in place comprehensive risk } \\
\text { management policies and processes to identify, evaluate, monitor and control or } \\
\text { mitigate material risks. The supervisor determines that these processes are adequate } \\
\text { for the size and nature of the activities of the bank and the banking group and are } \\
\text { periodically adjusted in the light of the changing risk profile of the bank or banking } \\
\text { group and external market developments. If the supervisor determines that the risk } \\
\text { management processes are inadequate, it has the power to require a bank or banking } \\
\text { group to strengthen them. }\end{array}$ \\
\hline $\begin{array}{l}\text { Description and } \\
\text { findings re EC1 }\end{array}$ & $\begin{array}{l}\text { Since the May } 2006 \text { BCP Assessment (LC), the BdE has started to enhance the } \\
\text { requirements and its supervision of banks' risk management systems and policies. } \\
\text { Laws and regulations have been amended to implement Basel Pillar } 2 \text { and the }\end{array}$ \\
\hline
\end{tabular}

\footnotetext{
${ }^{11}$ Assessors counted with the valuable assistance, on the field, of validation expert Min Qi, from U.S., Office of the Comptroller of the Currency (OCC).
} 


\begin{tabular}{|c|c|}
\hline & 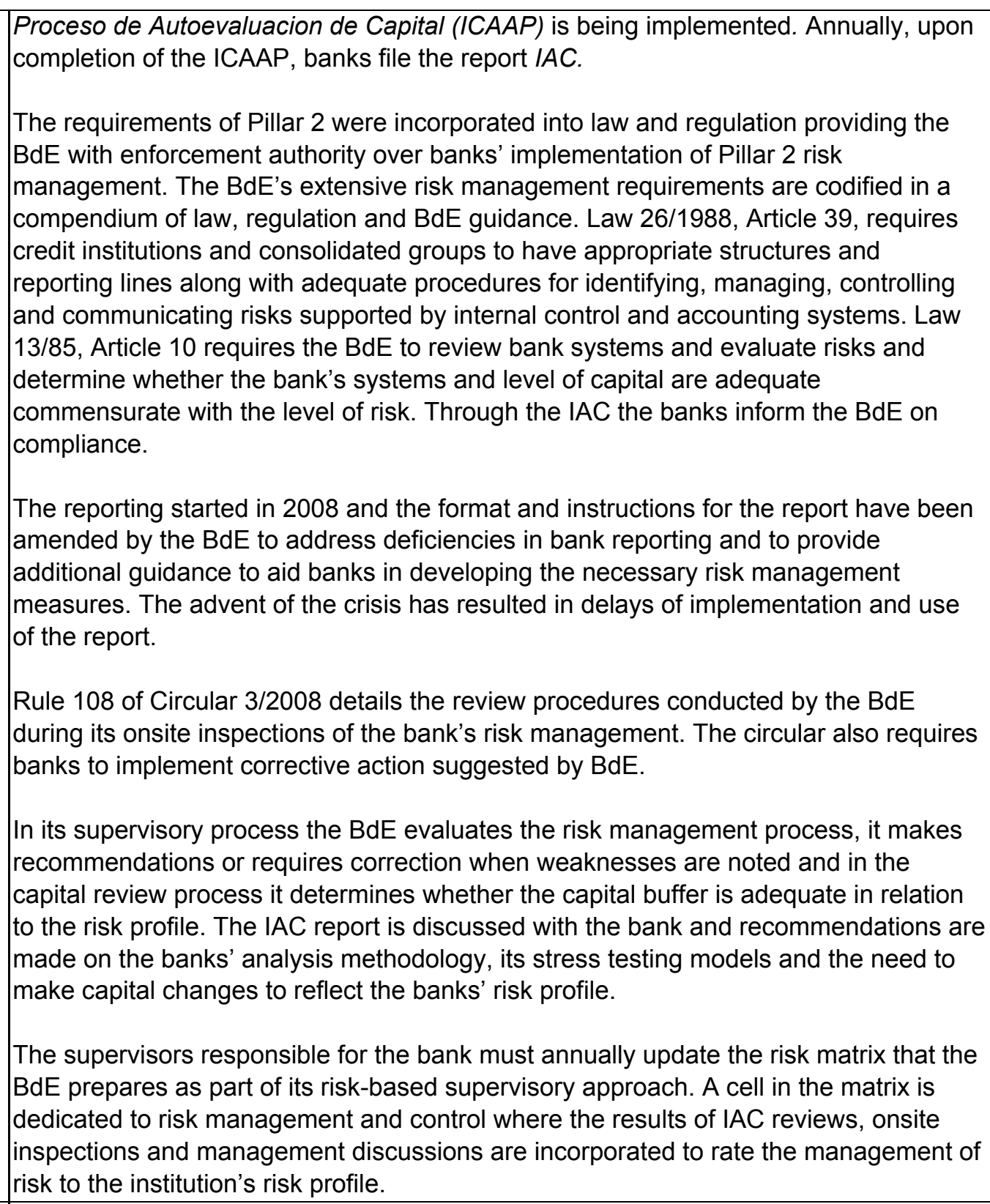 \\
\hline EC2 & $\begin{array}{l}\text { The supervisor confirms that banks and banking groups have appropriate risk } \\
\text { management strategies that have been approved by the board. The supervisor also } \\
\text { confirms that the board ensures that policies and processes for risk-taking are } \\
\text { developed, appropriate limits are established, and senior management takes steps } \\
\text { necessary to monitor and control all material risks consistent with the approved } \\
\text { strategies. }\end{array}$ \\
\hline $\begin{array}{l}\text { Description and } \\
\text { findings re EC2 }\end{array}$ & $\begin{array}{l}\text { Rules } 105,107 \text {, and } 108 \text { of Circular } 3 / 2008 \text { establish the requirements for banks to } \\
\text { provide the BdE with the information to monitor bank compliance with the } \\
\text { requirements to establish risk management systems. The BdE, through onsite and } \\
\text { offsite reviews, ensures that the Board is meeting its responsibilities as detailed in } \\
\text { Circular } 3 / 2008 \text {. } \\
\text { In their annual IAC report the banks must address the risk management requirements } \\
\text { established by the BdE and provide an assessment of internal governance. The report }\end{array}$ \\
\hline
\end{tabular}




\begin{tabular}{|c|c|}
\hline & $\begin{array}{l}\text { is filed annually and is reviewed and discussed with the banks. The report covers: } \\
\text { - Internal governance assessment. } \\
\text { - } \text { Organization of the risk function. } \\
\text { - Overall assessment of risk management. } \\
\text { During its onsite inspections, the BdE reviews Board of Director and executive } \\
\text { committee minutes to ensure that the Board is reviewing and updating policies. The } \\
\text { BdE also conducts targeted inspections that focus on corporate governance. A review } \\
\text { of inspection deficiencies follow-up actions, disclosed specific requirements placed on } \\
\text { banks for correcting deficiencies and timeframes. }\end{array}$ \\
\hline EC3 & $\begin{array}{l}\text { The supervisor determines that risk management strategies, policies, processes and } \\
\text { limits are properly documented, reviewed and updated, communicated within the bank } \\
\text { and banking group, and adhered to in practice. The supervisor determines that } \\
\text { exceptions to established policies, processes and limits receive the prompt attention of } \\
\text { and authorization by the appropriate level of management and the Board where } \\
\text { necessary. }\end{array}$ \\
\hline $\begin{array}{l}\text { Description and } \\
\text { findings re EC3 }\end{array}$ & $\begin{array}{l}\text { The BdE relies, to a large extent, on the work of the bank's internal audit work. } \\
\text { Guidelines for the scope of the internal audit work in the risk management area } \\
\text { include: monitoring compliance with risk management rules and internal limits, } \\
\text { suitability of risk management systems, assess risk measurement technologies and } \\
\text { review of internal control functions. Results of the audit are included in the annual IAC } \\
\text { report to the BdE. Additionally, BdE reviews workpapers and meets with internal } \\
\text { auditors during onsite inspections. } \\
\text { Also, during onsite inspections, and ongoing on site supervision, a review of Board } \\
\text { minutes is conducted and risk management analyzed. }\end{array}$ \\
\hline EC4 & $\begin{array}{l}\text { The supervisor determines that senior management and the board understand the } \\
\text { nature and level of risk being taken by the bank and how this risk relates to adequate } \\
\text { capital levels. The supervisor also determines that senior management ensure that the } \\
\text { risk management policies and processes are appropriate in the light of the bank's risk } \\
\text { profile and business plan and that they are implemented effectively. This includes a } \\
\text { requirement that senior management regularly reviews and understand the } \\
\text { implications (and limitations) of the risk management information that it receives. The } \\
\text { same requirement applies to the board in relation to risk management information } \\
\text { presented to it in a format suitable for board oversight. }\end{array}$ \\
\hline $\begin{array}{l}\text { Description and } \\
\text { findings re EC4 }\end{array}$ & $\begin{array}{l}\text { The IAC must specifically address the functions and responsibilities of the Board of } \\
\text { Directors relating to risk management, internal controls and capital adequacy. The IAC } \\
\text { must address the Board's actions to accomplish the following responsibilities: setting } \\
\text { the nature and level of risk borne by the bank, the level of capital in relation to the level } \\
\text { of risk, setting guidelines to establish the corporate risk culture, ensuring that internal } \\
\text { controls are adequate in light of the bank's risks, and ensuring that the sophistication } \\
\text { of risk management is commensurate with the risk level of the bank. } \\
\text { The IAC has disclosed a broad spectrum in understanding and development of risk } \\
\text { management systems. The focus of the BdE has, to a large extent, been diverted to } \\
\text { crisis management and the emphasis devoted to the former Cajas that have now } \\
\text { transformed into bank holding companies and need to adapt corporate governance } \\
\text { has been on restructuring and credit risk. }\end{array}$ \\
\hline
\end{tabular}




\begin{tabular}{|c|c|}
\hline EC5 & $\begin{array}{l}\text { The supervisor determines that the banks have an internal process for assessing their } \\
\text { overall capital adequacy in relation to their risk profile, and reviews and evaluates } \\
\text { bank's internal capital adequacy assessments and strategies. The nature of the } \\
\text { specific methodology used for this assessment will depend on the size, complexity and } \\
\text { business strategy of a bank. Non-complex banks may opt for a more qualitative } \\
\text { approach to capital planning. }\end{array}$ \\
\hline $\begin{array}{l}\text { Description and } \\
\text { findings re EC5 }\end{array}$ & $\begin{array}{l}\text { As detailed above, the BdE requires banks to file an annual detailed IAC report. The } \\
\text { report is reviewed focusing on the quality of the document, comparing the bank's self- } \\
\text { assessment with the BdE's risk matrix and rating of the bank, gauging adequacy of } \\
\text { capital in relation to risk profile and a review of strategic plans. }\end{array}$ \\
\hline EC6 & $\begin{array}{l}\text { Where banks and banking groups use models to measure components of risk, the } \\
\text { supervisor determines that banks perform periodic and independent validation and } \\
\text { testing of the models and systems. }\end{array}$ \\
\hline $\begin{array}{l}\text { Description and } \\
\text { findings re EC6 }\end{array}$ & $\begin{array}{l}\text { Rules } 22,31,92 \text {, and } 98 \text { of Circular } 3 / 2008 \text { establish the requirements for banks' use } \\
\text { of models. Banks are required to revalidate the models on a regular cycle and conduct } \\
\text { back-testing to validate results. Annually the bank must also review borrowers' ratings } \\
\text { and the exposures. Section } 5.2 .2 \text { of the BdE guide for evaluation of bank capital refers } \\
\text { to the annual onsite reviews to analyze the banks models. } \\
\text { The BdE has a staff of experts involved in model validation and in reviewing the work } \\
\text { by the banks in the use of models. }\end{array}$ \\
\hline EC7 & $\begin{array}{l}\text { The supervisor determines that bank and banking groups have adequate information } \\
\text { systems for measuring, assessing and reporting on the size, composition and quality } \\
\text { of exposures. It is satisfied that these reports are provided on a timely basis to the } \\
\text { board or senior management and reflect the bank's risk profile and capital needs. }\end{array}$ \\
\hline $\begin{array}{l}\text { Description and } \\
\text { findings re EC7 }\end{array}$ & $\begin{array}{l}\text { The ICAAP reporting instructions require banks to implement the adequate tools and } \\
\text { procedures for the management of risk, including risk measurement, risk assessment } \\
\text { methodology, the approval, communication, control and monitoring systems and the } \\
\text { information technology(IT) systems supporting management and stress testing. Onsite } \\
\text { inspections review bank practices including the IT systems. }\end{array}$ \\
\hline EC8 & $\begin{array}{l}\text { The supervisor determines that banks have policies and processes in place to ensure } \\
\text { that new products and major risk management initiatives are approved by the board or } \\
\text { a specific committee of the board. }\end{array}$ \\
\hline $\begin{array}{l}\text { Description and } \\
\text { findings re EC8 }\end{array}$ & $\begin{array}{l}\text { Circular } 3 / 2008 \text {, Rule } 105 \text { establishes Board responsibility related to the approval of } \\
\text { risk policies. The policies must be reviewed annually, at a minimum. Banks are } \\
\text { required to have an authorization committee for new products that gauges the impact } \\
\text { on the banks' risk and whether risk management systems need adjusting. BdE } \\
\text { reviews the reports filed by the banks and verifies during onsite inspections. }\end{array}$ \\
\hline EC9 & $\begin{array}{l}\text { The supervisor determines that banks and banking groups have risk evaluation, } \\
\text { monitoring and control or mitigation functions with duties clearly segregated from risk- } \\
\text { taking functions in the bank, and which report on risk exposures directly to senior } \\
\text { management and the board. }\end{array}$ \\
\hline $\begin{array}{l}\text { Description and } \\
\text { findings re EC9 }\end{array}$ & $\begin{array}{l}\text { Section of the ICAAP guidelines on risk management requires banks to report on the } \\
\text { organization of the risk management function to meet the BdE requirements } \\
\text { established in Circular } 3 / 2008 \text {. The report addresses the hierarchy established in the } \\
\text { institution and the delegation of functions and responsibilities. The levels of } \\
\text { management centralization-decentralization, the boundaries of responsibility and } \\
\text { authorization, and the separation of the functions of the various risk management } \\
\text { bodies should be explained. }\end{array}$ \\
\hline EC10 & The supervisor issues standards related to, in particular, credit risk, market risk, \\
\hline
\end{tabular}




\begin{tabular}{|c|c|}
\hline & liquidity risk, IRR in the banking book and operational risk. \\
\hline $\begin{array}{l}\text { Description and } \\
\text { findings re EC10 }\end{array}$ & $\begin{array}{l}\text { The BdE has issued standards through the ICAAP guidelines and Circular } 3 / 2008 \\
\text { concerning IRR, credit concentration, liquidity risk and operational risk. These } \\
\text { guidelines are further discussed in the relevant CPs below. }\end{array}$ \\
\hline \multicolumn{2}{|l|}{$\begin{array}{l}\text { Additional } \\
\text { criteria }\end{array}$} \\
\hline AC1 & $\begin{array}{l}\text { The supervisor requires larger and more complex banks to have a dedicated unit(s) } \\
\text { responsible for risk evaluation, monitoring and control or mitigation for material risk } \\
\text { areas. The supervisor confirms that this unit (these units) is (are) subject to periodic } \\
\text { review by the internal audit function. }\end{array}$ \\
\hline $\begin{array}{l}\text { Description and } \\
\text { findings re } A C 1\end{array}$ & $\begin{array}{l}\text { For large and more complex banks, the ICAAP guidelines require the establishment of } \\
\text { an area focusing on the overall risk management and controls. Banks are required to } \\
\text { report to the BdE on how the area integrates functionally and organizationally to the } \\
\text { rest of the bank. Additionally, large and complex banks have continuous onsite } \\
\text { presence by BdE inspectors that monitor the area. }\end{array}$ \\
\hline AC2 & $\begin{array}{l}\text { The supervisor requires banks to conduct rigorous, forward-looking testing that } \\
\text { identifies possible events or changes in market conditions that could adversely impact } \\
\text { on the bank. }\end{array}$ \\
\hline $\begin{array}{l}\text { Description and } \\
\text { findings re AC2 }\end{array}$ & $\begin{array}{l}\text { Section } 3.5 \text { on Capital Planning of the ICAAP requires banks to make capital needs } \\
\text { projections considering the bank's strategic plan, retained earnings, dividend payout } \\
\text { rates, and projected asset growth. Stress tests should also be conducted to identify } \\
\text { those events or changes in market conditions that may affect future capital needs. } \\
\text { The bank must develop contingency plans to address possible capital shortfalls. }\end{array}$ \\
\hline AC3 & $\begin{array}{l}\text { The supervisor requires banks and banking groups to have in place appropriate } \\
\text { policies and processes for assessing other material risks not directly addressed in the } \\
\text { subsequent CPs, such as reputational and strategic risks. }\end{array}$ \\
\hline $\begin{array}{l}\text { Description and } \\
\text { findings re AC3 }\end{array}$ & $\begin{array}{l}\text { Rule } 105(2)(\mathrm{VIII}) \text { of CBE } 3 / 2008 \text {, includes a requirement to assess and control other } \\
\text { relevant risks, such as reputation risk. Additionally, the risk matrix employed by the } \\
\text { BdE reviews and considers reputational and business risks when assigning a risk } \\
\text { rating to the bank. }\end{array}$ \\
\hline \begin{tabular}{|l} 
Assessment of \\
Principle 7
\end{tabular} & Largely Compliant \\
\hline Comments & $\begin{array}{l}\text { A review of inspection documents and systems highlighted the emphasis placed on } \\
\text { risk management by the BdE on its onsite inspections. Bank meetings also shed light } \\
\text { into the advanced risk management practices of the systemic banks. } \\
\text { The LC grading in } 2006 \text { was based on the lack of ability to issue guidance on best } \\
\text { practices and to require correction. The implementation of EU Directive } 48 / 2006 \text { on } \\
\text { Pillar } 2 \text { has addressed the } 2006 \text { deficiency. The steps taken to implement Pillar } 2 \\
\text { compliance and monitoring are well-defined and the IAC report implemented is } \\
\text { comprehensive and provides guidance to banks for benchmarking. The report was } \\
\text { designed to fit well into supervision by risk and feeding SABER and the supervisory } \\
\text { risk matrix. However, the IAC implementation has been difficult for some institutions } \\
\text { and continues to be adjusted since initiated in } 2008 \text {, the current version appears to be } \\
\text { very workable. The wave of mergers and the need for crisis management has slowed } \\
\text { the IAC implementation and bank-by-bank evaluation, therefore, effective } \\
\text { implementation of this CP in the system, in particular the new banks, cannot be fully } \\
\text { assessed at this point. }\end{array}$ \\
\hline Principle 8. & $\begin{array}{l}\text { Credit risk. Supervisors must be satisfied that banks have a credit risk management } \\
\text { process that takes into account the risk profile of the institution, with prudent policies } \\
\text { and processes to identify, measure, monitor and control credit risk (including }\end{array}$ \\
\hline
\end{tabular}




\begin{tabular}{|c|c|}
\hline & $\begin{array}{l}\text { counterparty risk). This would include the granting of loans and making of investments, } \\
\text { the evaluation of the quality of such loans and investments, and the ongoing } \\
\text { management of the loan and investment portfolios. }\end{array}$ \\
\hline \multicolumn{2}{|l|}{$\begin{array}{l}\text { Essential } \\
\text { criteria }\end{array}$} \\
\hline EC1 & $\begin{array}{l}\text { The supervisor determines, and periodically confirms, that a bank's Board approves, } \\
\text { and periodically reviews, the credit risk management strategy and significant policies } \\
\text { and processes for assuming, identifying, measuring, controlling and reporting on credit } \\
\text { risk (including counterparty risk). The supervisor also determines, and periodically } \\
\text { confirms, that senior management implements the credit risk strategy approved by the } \\
\text { Board and develops the aforementioned policies and processes. }\end{array}$ \\
\hline $\begin{array}{l}\text { Description and } \\
\text { findings re EC1 }\end{array}$ & $\begin{array}{l}\text { Article } 6.4 \text { of Law } 13 / 1985 \text {, Article } 2 \text { of Royal Decree } 1245 / 1995 \text { and Article } 66 \text { of } \\
\text { Royal Decree } 216 / 2008 \text { form a compendium establishing requirements for the Board } \\
\text { to establish risk measurement and control over credit risk. } \\
\text { Annex IX of Circular } 4 / 2004 \text { establishes that the policies, methods and procedures } \\
\text { should be approved by the Board of Directors, be fully documented, relate risk to the } \\
\text { borrowers' ability to repay, establish realistic repayment plans based on loan term and } \\
\text { purpose, establish minimum collateral re-assessment requirements, set financing } \\
\text { terms for connected entities that are similar to market terms, establish LTV limits. The } \\
\text { BdE maintains a credit registry that permits the monitoring of credit trends and loan } \\
\text { quality. } \\
\text { Verification of compliance with requirements of EC } 1 \text { is a primary emphasis of the BdE } \\
\text { supervisory process. The onsite process includes, as detailed in the BdE risk-based } \\
\text { supervisory approach (SABER): } 1 \text { ) Reviewing the minutes and reports presented to } \\
\text { the Board and the various risk management bodies. 2) Meeting with the management } \\
\text { responsible for the credit risk areas. 3) Review of files documenting loan granting } \\
\text { processes and monitoring. }\end{array}$ \\
\hline EC2 & $\begin{array}{l}\text { The supervisor requires, and periodically confirms, that such policies and processes } \\
\text { establish an appropriate and properly controlled credit risk environment, including: } \\
\text { - a well-documented strategy and sound policies and processes for assuming } \\
\text { credit risk; } \\
\text { - well defined criteria and policies and processes for approving new exposures as } \\
\text { well as renewing and refinancing existing exposures, identifying the appropriate } \\
\text { approval authority for the size and complexity of the exposures; } \\
\text { - effective credit administration policies and processes, including continued } \\
\text { analysis of a borrower's ability and willingness to repay under the terms of the } \\
\text { debt, monitoring of documentation, legal covenants, contractual requirements } \\
\text { and collateral, and a classification system that is consistent with the nature, size } \\
\text { and complexity of the bank's activities or, at the least, with the asset grading } \\
\text { system prescribed by the supervisor; } \\
\text { comprehensive policies and processes for reporting exposures on an ongoing } \\
\text { basis; } \\
\text { comprehensive policies and processes for identifying problem assets; and } \\
\text { prudent lending controls and limits, including policies and processes for } \\
\text { monitoring exposures in relation to limits, approvals and exceptions to limits. }\end{array}$ \\
\hline
\end{tabular}




\begin{tabular}{|c|c|}
\hline $\begin{array}{l}\text { Description and } \\
\text { findings re EC2 }\end{array}$ & $\begin{array}{l}\text { Order EHA/2899/2011 requires credit institutions before entering into a lending } \\
\text { arrangement with a borrower to assess the borrower's ability to repay. Procedures to } \\
\text { be followed include: assessing the employment, income and financial situation of the } \\
\text { borrower by reviewing borrowing history in the BdE credit registry, value collateral } \\
\text { conservatively, do not rely solely on collateral value but on cash flow. } \\
\text { The supervision process reviews the loan documentation, review borrower record and } \\
\text { credit history, review internal reports concerning loan portfolio, loan provisions, ensure } \\
\text { that the loan review function is separate from the loan granting function. Borrower files } \\
\text { are reviewed to ensure that adequate information is collected to support the } \\
\text { borrower's ability to repay the loan. Also reviewed are all the policies adopted by the } \\
\text { Board to control credit risk and the banks risk management systems. }\end{array}$ \\
\hline EC3 & $\begin{array}{l}\text { The supervisor requires, and periodically confirms, that banks make credit decisions } \\
\text { free of conflicts of interest and on an arm's length basis. }\end{array}$ \\
\hline $\begin{array}{l}\text { Description and } \\
\text { findings re EC3 }\end{array}$ & $\begin{array}{l}\text { Annex IX of Regulation } 4 / 2004 \text { requires banks to set policies, methods and } \\
\text { procedures for the documenting, granting and analysis of lending. These policies will } \\
\text { set conditions and financing terms to related entities similar to those granted to entities } \\
\text { with similar risk characteristics. } \\
\text { BdE examines to ensure that banks have an appropriate organizational structure for } \\
\text { credit approval to ensure compliance with the above requirement. Specifically, loans to } \\
\text { Directors, companies related to those directors and the bank's economic group are } \\
\text { monitored using the information contained in the minutes of meetings of governing } \\
\text { bodies, the information submitted monthly to the BdE credit registry and the quarterly } \\
\text { reporting of risk exposures to related persons or companies. }\end{array}$ \\
\hline EC4 & $\begin{array}{l}\text { The supervisor has full access to information in the credit and investment portfolios } \\
\text { and to the bank officers involved in assuming, managing, controlling and reporting on } \\
\text { credit risk. }\end{array}$ \\
\hline $\begin{array}{l}\text { Description and } \\
\text { findings re EC4 }\end{array}$ & $\begin{array}{l}\text { Article } 43 \text { bis, Law } 26 / 1988 \text {; the BdE is entitled to require any information needed to } \\
\text { verify that banks are complying with existing regulations. } \\
\text { Article } 9.2 \text {, of Law } 13 / 1985 \text {; the BdE may require entities subject to consolidated } \\
\text { supervision to provide whatever information may be needed to verify consolidation, } \\
\text { analyze the risk assumed by the consolidated entities and assess the adequacy of the } \\
\text { risk management processes of the consolidated group. BdE also has the power to } \\
\text { inspect the books, documentation and records of the entities. }\end{array}$ \\
\hline \multicolumn{2}{|l|}{$\begin{array}{l}\text { Additional } \\
\text { criteria }\end{array}$} \\
\hline AC1 & $\begin{array}{l}\text { The supervisor requires that the credit policy prescribes that major credit risk } \\
\text { exposures exceeding a certain amount or percentage of the bank's capital are to be } \\
\text { decided by the bank's senior management. The same applies to credit risk exposures } \\
\text { that are especially risky or otherwise not in line with the mainstream of the bank's } \\
\text { activities. }\end{array}$ \\
\hline $\begin{array}{l}\text { Description and } \\
\text { findings re AC1 }\end{array}$ & $\begin{array}{l}\text { Annex IX of Regulation } 4 / 2004.1 \text {. requires that lending policies include the rules and } \\
\text { procedures that must be followed to grant exceptions to policy, particularly as it relates } \\
\text { to transactions that are not covered by the general conditions and limits established. } \\
\text { During the inspections, the BdE analyses documents written and approved by the } \\
\text { Board setting out the criteria, ensures that there is adequate separation of duties and } \\
\text { reviews the process for setting authorization limits and duties and responsibilities of } \\
\text { the various units involved. }\end{array}$ \\
\hline
\end{tabular}




\begin{tabular}{|c|c|}
\hline AC2 & $\begin{array}{l}\text { The supervisor determines that banks have in place policies and processes to identify, } \\
\text { measure, monitor and control counterparty credit risk exposure, including potential } \\
\text { future exposure sufficient to capture the material risks inherent in individual products } \\
\text { or transactions. These processes should be commensurate with the size or complexity } \\
\text { of the individual bank. }\end{array}$ \\
\hline $\begin{array}{l}\text { Description and } \\
\text { findings re AC2 }\end{array}$ & $\begin{array}{l}\text { The BdE considers counterparty risk to be a specific category within the general credit } \\
\text { risk analysis and is therefore also taken into account in the planning and execution of } \\
\text { supervisory activities, particularly for trading portfolios and derivatives. Onsite } \\
\text { examinations focus on the review of models used to calculate counterparty risk in } \\
\text { derivative transactions, analyze the bank's criteria for determining the credit quality of } \\
\text { treasury assets, and review the adequacy of risk limits. }\end{array}$ \\
\hline AC3 & $\begin{array}{l}\text { The supervisor determines that banks have policies and processes to monitor the total } \\
\text { indebtedness of entities to which they extend credit. }\end{array}$ \\
\hline $\begin{array}{l}\text { Description and } \\
\text { findings re AC3 }\end{array}$ & $\begin{array}{l}\text { Banks must report all credit extended to the BdE central credit registry. The registry } \\
\text { also allows banks calculate the overall debt of any counterparty through information } \\
\text { supplied to all the banks monthly. Rule } 102 ; \text { Circular } 3 / 2008 \text { provides instructions for } \\
\text { banks on how to aggregate borrowings and establishes the definition for borrowers to } \\
\text { be combined. }\end{array}$ \\
\hline $\begin{array}{l}\text { Assessment of } \\
\text { Principle } 8\end{array}$ & Compliant \\
\hline \multicolumn{2}{|l|}{ Comments } \\
\hline Principle 9. & $\begin{array}{l}\text { Problem assets, provisions and reserves. Supervisors must be satisfied that banks } \\
\text { establish and adhere to adequate policies and processes for managing problem } \\
\text { assets and evaluating the adequacy of provisions and reserves. }\end{array}$ \\
\hline \multicolumn{2}{|l|}{$\begin{array}{l}\text { Essential } \\
\text { criteria }\end{array}$} \\
\hline EC1 & $\begin{array}{l}\text { Laws, regulations or the supervisor require banks to formulate specific policies and } \\
\text { processes for identifying and managing problem assets. In addition, laws, regulations } \\
\text { or the supervisor require periodic review by banks of their problem assets (at an } \\
\text { individual level or at a portfolio level for credits with homogenous characteristics) and } \\
\text { asset classification, provisioning and write-offs. }\end{array}$ \\
\hline \multirow[t]{3}{*}{$\begin{array}{l}\text { Description and } \\
\text { findings re EC1 }\end{array}$} & $\begin{array}{l}\text { CBE 4/2004-Annex IX requires banks to have policies, methods and procedures to } \\
\text { address credit granting, analyzing and reviewing outstanding credits and identifying } \\
\text { impaired credits. Including sovereign debt. Impairment loss calculation models are } \\
\text { required to be part of the credit risk measurement process taking into account default } \\
\text { experience and business cycles. }\end{array}$ \\
\hline & $\begin{array}{l}\text { Regarding the estimation of impairment, the general framework is included in Rule } 29 \\
\text { of CBE } 4 / 2004 \text { where it stipulates the methodology has to take into account two basic } \\
\text { factors: impairment that is inherent in any financial asset portfolio, and impairment that } \\
\text { is influenced by business cycles. }\end{array}$ \\
\hline & $\begin{array}{l}\text { Annex IX also distinguishes impairment associated with normal, substandard, doubtful } \\
\text { (nonperforming) and write-off (loss) loans. BdE has issued guidelines for provisioning } \\
\text { doubtful loans that starts at } 25 \text { percent when a loan is six months delinquent, to } \\
100 \text { percent when the loan is } 12 \text { months delinquent. Collateral value is considered, as } \\
\text { the minimum original cost for the borrower or current appraisal, discounted by specific } \\
\text { hair-cut- for example residential real estate valuation is discounted } 20 \text { percent. There } \\
\text { is also a generic provision that is computed based on the historical loss rate for the } \\
\text { various classification categories. Loans classified substandard are reviewed } \\
\text { individually and provisions determined on a case-by-case analysis or as a group when }\end{array}$ \\
\hline
\end{tabular}




\begin{tabular}{|c|c|}
\hline & $\begin{array}{l}\text { To reflect the current real estate valuation uncertainties the MoF issued a one-time } \\
\text { provisioning requirement for the stock of real estate related loan portfolio as of } \\
12 / 31 / 2011 \text { to close its perceived gap in provisioning and current land and real estate } \\
\text { development conditions. The requirements include a collective impairment } \\
\text { assessment of seven percent for the "normal" construction and real estate developer } \\
\text { portfolio. For land development loans classified substandard or doubtful a } 60 \text { percent } \\
\text { provision is required and for housing under development a } 50 \text { percent provision is } \\
\text { required. } \\
\text { Banks must review their impairment computations at the time of preparation of } \\
\text { financial statement. }\end{array}$ \\
\hline EC2 & $\begin{array}{l}\text { The supervisor confirms the adequacy of the classification and provisioning policies } \\
\text { and processes of a bank and their implementation; the reviews supporting this opinion } \\
\text { may be conducted by external experts. }\end{array}$ \\
\hline & $\begin{array}{l}\text { Through onsite and offsite activities, including tracking exposures through the credit } \\
\text { registry, the BdE monitors bank credit quality. BdE inspects banks at least once every } \\
\text { three years but reviews of the loan portfolio are conducted more often. For the larger } \\
\text { banks it is conducted on an ongoing basis by the resident inspection staff. Currently, } \\
\text { the BdE has resident inspectors in the } 16 \text { largest banks. Also external auditors } \\
\text { produce annual reports on loan portfolios based on BdE standards which are provided } \\
\text { to the BdE. Off-balance sheet items are also reviewed. } \\
\text { Approximately, the largest } 200 \text { borrowers in the system are reviewed by a specialized } \\
\text { group to provide inspectors with a centralized classification and avoid differing } \\
\text { classifications of the same borrower. The BdE also reviews through the credit registry } \\
\text { how borrowers are classified by the different banks and follow-up on variances } \\
\text { between banks. }\end{array}$ \\
\hline EC3 & $\begin{array}{l}\text { The system for classification and provisioning takes into account off-balance sheet } \\
\text { exposures. }\end{array}$ \\
\hline $\begin{array}{l}\text { Description and } \\
\text { findings re EC3 }\end{array}$ & $\begin{array}{l}\text { Annex IX of Circular } 4 / 2004 \text { sets out specific rules for the review and classification of } \\
\text { off-balance sheet exposures and commitments and provisioning requirements. }\end{array}$ \\
\hline EC4 & $\begin{array}{l}\text { The supervisor determines that banks have appropriate policies and processes to } \\
\text { ensure that provisions and write-offs reflect realistic repayment and recovery } \\
\text { expectations. }\end{array}$ \\
\hline $\begin{array}{l}\text { Description and } \\
\text { findings re EC4 }\end{array}$ & $\begin{array}{l}\text { Section 1.d of Annex IX (CBE 4/2004) specifies that policies, methods and procedures } \\
\text { to be established by institutions in the granting, analysis and documentation of } \\
\text { classifications must be based on a realistic repayment schedule attuned to the } \\
\text { borrower's primary sources of income generation and the useful life of the collateral. } \\
\text { The BdE reviews banks' compliance with provisioning guidelines and requires banks } \\
\text { to effect correction for noncompliance. A review of inspection reports substantiates the } \\
\text { extensive review by the BdE of provisioning. }\end{array}$ \\
\hline EC5 & $\begin{array}{l}\text { The supervisor determines that banks have appropriate policies and processes, and } \\
\text { organizational resources for the early identification of deteriorating assets, for ongoing } \\
\text { oversight of problem assets, and for collecting on past due obligations. }\end{array}$ \\
\hline $\begin{array}{l}\text { Description and } \\
\text { findings re EC5 }\end{array}$ & $\begin{array}{l}\text { Determining the adequacy of policies and procedures concerning the identification of } \\
\text { problem assets is a critical step in the development of the risk matrix for banks that is } \\
\text { developed by the BdE as described in the SABER document. The BdE will rate credit } \\
\text { risk in the matrix and apportion resources to supervision of the bank based on the }\end{array}$ \\
\hline
\end{tabular}




\begin{tabular}{|c|c|}
\hline & $\begin{array}{l}\text { results of its analysis. } \\
\text { A review of supervisory files reveals that the BdE actively reviews and reclassifies } \\
\text { loans and requires additional provisions. }\end{array}$ \\
\hline EC6 & $\begin{array}{l}\text { The supervisor is informed on a periodic basis, and in relevant detail, or has access to } \\
\text { information concerning the classification of credits and assets and provisioning. }\end{array}$ \\
\hline $\begin{array}{l}\text { Description and } \\
\text { findings re EC6 }\end{array}$ & $\begin{array}{l}\text { Banks must submit Confidential Returns as required by CBE 4/2004-Titlell. These } \\
\text { reports have credit information at the individual borrower level and are filed quarterly. } \\
\text { There is also a consolidated report filed quarterly. The BdE credit registry contains } \\
\text { information on all borrowers with outstanding debt over } 6,000 \text { Euros and how it is } \\
\text { classified at the various banks. }\end{array}$ \\
\hline EC7 & $\begin{array}{l}\text { The supervisor has the power to require a bank to increase its levels of provisions and } \\
\text { reserves and/or overall financial strength if it deems the level of problem assets to be } \\
\text { of concern. }\end{array}$ \\
\hline $\begin{array}{l}\text { Description and } \\
\text { findings re EC7 }\end{array}$ & $\begin{array}{l}\text { Article } 47 . a \text { of the Banking Law of } 1946 \text { assigns responsibility to the BdE to make } \\
\text { recommendations to the banks concerning their credit practices and policies. Articles } \\
4(f) \text { and } 5(k) \text { makes it a violation of regulation to have insufficient provisions and } \\
\text { enable the BdE to take action to ensure the bank's books accurately reflect the bank's } \\
\text { condition. } \\
\text { The subject of provision adequacy is addressed in the letters the BdE sends banks at } \\
\text { the conclusion of its supervisory activities and may include a requirement to increase } \\
\text { provisions. The BdE takes supervisory enforcement actions when corrections are not } \\
\text { implemented. }\end{array}$ \\
\hline EC8 & $\begin{array}{l}\text { The supervisor assesses whether the classification of the credits and assets and the } \\
\text { provisioning is adequate for prudential purposes. If provisions are deemed to be } \\
\text { inadequate, the supervisor has the power to require additional provisions or to impose } \\
\text { other remedial measures. }\end{array}$ \\
\hline $\begin{array}{l}\text { Description and } \\
\text { findings re EC8 }\end{array}$ & $\begin{array}{l}\text { The BdE is empowered to require provisions in conformity with CBE } 4 / 2004 \text { and Law } \\
26 / 1988 \text { when it determines that the level of provisions is inadequate Numerous letters } \\
\text { of follow-up to the banks reviewed during the assessment contained references of } \\
\text { loans reclassified by inspectors and the amounts of additional provision required. }\end{array}$ \\
\hline EC9 & $\begin{array}{l}\text { The supervisor requires banks to have appropriate mechanisms in place for } \\
\text { periodically assessing the value of risk mitigants, including guarantees and collateral. } \\
\text { The valuation of collateral is required to reflect the net realizable value. }\end{array}$ \\
\hline $\begin{array}{l}\text { Description and } \\
\text { findings re EC9 }\end{array}$ & $\begin{array}{l}\text { Annex IX CBE } 4 / 2004 \text { Sections } 1 . h \text { and } 1 . i \text { addresses the valuation of collateral } \\
\text { requiring prudence in the use of appraisal values. Banks must use their own } \\
\text { professional judgment in valuation and not rely completely on appraisal values and } \\
\text { assess critically aspects such as the degree of potential liquidity accounting for decline } \\
\text { in value in a stress situation. Banks are required to establish a minimum frequency for } \\
\text { reviewing loan collateral and update the appraisals by linking them to changes in the } \\
\text { market for the asset received as collateral or acquired in payment of debt. In order to } \\
\text { estimate impairment of a doubtful loan when residential real estate collateral is } \\
\text { available, for instance, the valuation refers not only to an appraisal value but also to } \\
\text { the original cost of the asset as a limit on the valuation. } \\
\text { However, it has become evident in the current crisis that the valuation process had not }\end{array}$ \\
\hline
\end{tabular}




\begin{tabular}{|c|c|}
\hline & $\begin{array}{l}\text { served to rebuild provisions at an early stage, requiring the recent program for a one- } \\
\text { off systemic provision build-up. }{ }^{12} \text { Additionally, the due diligence process in the creation } \\
\text { of banks based on the conglomeration of a number of savings banks has identified the } \\
\text { need for significant provisioning in the new banks. }\end{array}$ \\
\hline EC10 & $\begin{array}{l}\text { Laws, regulations or the supervisor establish criteria for assets to be identified as } \\
\text { impaired, e.g., loans are identified as impaired when there is reason to believe that all } \\
\text { amounts due (including principal and interest) will not be collected in accordance with } \\
\text { the contractual terms of the loan agreement. }\end{array}$ \\
\hline $\begin{array}{l}\text { Description and } \\
\text { findings re EC10 }\end{array}$ & $\begin{array}{l}\text { Annex IX, Section } 7 . d \text { CBE } 4 / 2004 \text { requires banks to identify assets as impaired when: } \\
\text { 1. There are reasonable doubts about their full repayment (principal and interest) } \\
\text { under contractual terms or } 2 \text {. Any part of the principal, interest or contractually agreed } \\
\text { expenses is past-due more than three months. Spain follows IFRS standards. }\end{array}$ \\
\hline EC11 & $\begin{array}{l}\text { The supervisor determines that the Board receives timely and appropriate information } \\
\text { on the condition of the bank's asset portfolio, including classification of credits, the } \\
\text { level of provisioning and major problem assets. }\end{array}$ \\
\hline $\begin{array}{l}\text { Description and } \\
\text { findings re EC11 }\end{array}$ & $\begin{array}{l}\text { The scope of onsite inspections includes reviews of reports to the Board of Directors } \\
\text { and management to verify the nature and extent of the information provided. }\end{array}$ \\
\hline EC12 & $\begin{array}{l}\text { The supervisor requires that valuation, classification and provisioning for large } \\
\text { exposures are conducted on an individual item basis. }\end{array}$ \\
\hline $\begin{array}{l}\text { Description and } \\
\text { findings re EC12 }\end{array}$ & $\begin{array}{l}\text { Paragraph } 9 \text { of Rule } 29 \text { of CBE } 4 / 2004 \text { stipulates that the objective evidence of } \\
\text { impairment shall be determined individually for all loans that are significant. Inspectors } \\
\text { verify compliance during onsite inspections. Confirmation is also made through } \\
\text { sampling the BdE credit registry. }\end{array}$ \\
\hline \multicolumn{2}{|l|}{$\begin{array}{l}\text { Additional } \\
\text { criteria }\end{array}$} \\
\hline AC1 & $\begin{array}{l}\text { Loans are required to be classified when payments are contractually a minimum } \\
\text { number of days in arrears (eg } 30,60,90 \text { days). Refinancing of loans that would } \\
\text { otherwise fall into arrears does not lead to improved classification for such loans. }\end{array}$ \\
\hline $\begin{array}{l}\text { Description and } \\
\text { findings re AC1 }\end{array}$ & $\begin{array}{l}\text { Loans are classified as impaired after } 90 \text { days delinquency. A restructuring or } \\
\text { extension will not remove the loan from past-due status or result in a reclassification to } \\
\text { standard until there is reasonable certainty that the borrower will be able to make } \\
\text { payments or quality collateral provided and all interest payments are current. Other } \\
\text { classifications are made based on individual loan characteristics. }\end{array}$ \\
\hline $\begin{array}{l}\text { Assessment of } \\
\text { Principle } 9\end{array}$ & Largely Compliant \\
\hline Comments & $\begin{array}{l}\text { The BdE approach to provisioning is conservative and the use of a dynamic } \\
\text { provisioning element provided an additional cushion to support the initial effects of the } \\
\text { crisis. As the market conditions deteriorated in the prolonged crisis, however, it was } \\
\text { clear that the conservativeness of banks' provisioning was not homogeneous, in } \\
\text { particular with regards to the valuation of real estate collateral. Therefore, although the } \\
\text { BdE has established detailed loan classification and provisioning requirements and its } \\
\text { supervisory efforts focus on the review of the loan portfolio, the system results have } \\
\text { had to be supplemented by broader government action. The requirement for a large }\end{array}$ \\
\hline
\end{tabular}

\footnotetext{
${ }^{12}$ During the assessment, the Government issued RDL2/2012 which responded to market concerns regarding the level of provisioning given uncertainty on the value of real estate collateral. Measures affected mostly the outstanding stock of real estate exposure existing on December 31, 2011, and included additional specific and generic provisions based on the value of the loan, disregarding the value of the collateral. The RDL and valuation issues are detailed in a separate TN produced during the FSAP.
} 


\begin{tabular}{|c|c|}
\hline & $\begin{array}{l}\text { catch-up provision for the system and the large amounts of provisioning and capital } \\
\text { support required in the conglomeration of savings into commercial banks indicates that } \\
\text { the process of provisioning did not lead to prompt adjustments in light of the crisis. } \\
\text { BdE is currently reviewing its framework for the valuation of real estate collateral, and } \\
\text { its implementation should be an important element for the full compliance with this CP. } \\
\text { Additionally, as it is expected that dynamic/generic provisioning fades from use as a } \\
\text { supervisory tool in the new EU common regulatory framework, provisioning levels on } \\
\text { an ongoing basis will need to be adjusted to ensure adequacy of credit loss estimation }\end{array}$ \\
\hline Principle 10. & $\begin{array}{l}\text { Large exposure limits. Supervisors must be satisfied that banks have policies and } \\
\text { processes that enable management to identify and manage concentrations within the } \\
\text { portfolio, and supervisors must set prudential limits to restrict bank exposures to single } \\
\text { counterparties or groups of connected counterparties. }\end{array}$ \\
\hline \multicolumn{2}{|r|}{ t } \\
\hline EC1 & $\begin{array}{l}\text { Laws or regulations explicitly define, or the supervisor has the power to define, a } \\
\text { "group of connected counterparties" to reflect actual risk exposure. The supervisor } \\
\text { may exercise discretion in applying this definition on a case by case basis. }\end{array}$ \\
\hline $\begin{array}{l}\text { Description and } \\
\text { findings re } E C 1\end{array}$ & $\begin{array}{l}\text { The definition of "group" in company law is contained in Article } 42.1 \text { of the } \\
\text { Commercial Code of } 1885 \text { : a "group" is said to exist when several companies form a } \\
\text { decision-making unit, established when institutions have, directly or indirectly, control } \\
\text { over others. This control can be qualified in several ways: such as having the majority } \\
\text { of voting power, the capacity to nominate the majority of the board, including using } \\
\text { third party intermediary or agreements to this end. Article } 1.1 . \mathrm{g} \text { ) of RD } 216 / 2008 \\
\text { defines that entities or individuals, whatever the nature of their activities, which act as } \\
\text { a decision making unit, shall be considered a group. CBE } 8 / 2008 \text {, Article } 102 \text {, further } \\
\text { expands the concept for large exposures application, adding to the commercial code } \\
\text { definition individuals and companies where a decision-unit is indentified, even when } \\
\text { there is no majority in voting rights. Article } 63.3 \text { of RD } 216 / 2008 \text {; and Articles } 102.3 \\
\text { and } 102.4 \text { of CBE } 3 / 08 \text { : determine that_BdE may stipulate that specific groups of } \\
\text { customers be considered as a single unit, even though they do not belong to the same } \\
\text { economic group and this status shall apply from that point onward. }\end{array}$ \\
\hline EC2 & $\begin{array}{l}\text { Laws, regulations or the supervisor set prudent limits on large exposures to a single } \\
\text { counterparty or a group of connected counterparties. "Exposures" include all claims } \\
\text { and transactions, on-balance sheet as well as off-balance sheet. The supervisor } \\
\text { confirms that senior management monitors these limits and that they are not exceeded } \\
\text { on a solo or consolidated basis. }\end{array}$ \\
\hline $\begin{array}{l}\text { Description and } \\
\text { findings re EC2 }\end{array}$ & $\begin{array}{l}\text { Article } 101 \text { of CBE } 3 / 08 \text { defines as large exposures those exposures against a client } \\
\text { (group definition, see EC1) that exceeds } 10 \text { percent of the bank's regulatory capital. } \\
\text { The value of any individual such large exposure cannot exceed } 25 \text { percent of the } \\
\text { bank's regulatory capital. If the client is a credit entity (or the group includes at least } \\
\text { one credit entity), this limit will be the largest of } 25 \text { percent of regulatory capital or } \\
150 \text { million Euros. Article } 102.5 \text { determines that such exposures and limits are to be } \\
\text { calculated aggregating on and off balance exposures. Article } 5.1 \text { determines that such } \\
\text { limits will need to be observed both on a solo and a consolidated basis. The } \\
\text { exceptions to the limits are those in the EC Directives, as transposed by RD } 216 / 2008 \\
\text { (Article } 64 \text { ) and Article } 103 \text { CBE } 3 / 2008 \text { : Exposures eligible to } 0 \text { percent RW, } \\
\text { exposures to foreign governments and central Banks that are not subject to a } 100 \\
\text { percent RW, when denominated in a currency common to the lender and the } \\
\text { borrower, investment in insurance up to } 40 \text { percent of the bank's capital, etc. } \\
\text { Articles } 105.1 \text { and } 105.2 \text { state that the Board must approve and periodically review the }\end{array}$ \\
\hline
\end{tabular}




\begin{tabular}{|c|c|}
\hline & policies for large exposure management and control. \\
\hline EC3 & $\begin{array}{l}\text { The supervisor determines that a bank's management information systems identify } \\
\text { and aggregate on a timely basis exposure to individual counterparties and groups of } \\
\text { connected counterparties. }\end{array}$ \\
\hline $\begin{array}{l}\text { Description and } \\
\text { findings re EC3 }\end{array}$ & $\begin{array}{l}\text { Article } 63.3, \text { RD } 216 / 2008 \text { determines that banks must continuously monitor the } \\
\text { concentration of risks by internal control and measurement mechanisms. These } \\
\text { mechanisms must allow the banks to indentify and register all large exposures, to } \\
\text { monitor and control them according to the policy established by the Board, with } \\
\text { particular attention to the linkages between participations, mutual guarantees and } \\
\text { commercial dependence between clients. CBE } 4 / 2004 \text {. Article } 72.3 \text {, further determines } \\
\text { that banks must have sufficient information to assess concentration risk. In this sense, } \\
\text { Article } 122 \text { of CBE } 3 / 08 \text { establishes that banks must send quarterly the supervisory } \\
\text { reports RP } 60 \text { and RP61, which contain detailed information on large exposures, } \\
\text { composition of client groups, and occasional breaches of limits. The largest } 20 \\
\text { borrowers must be informed, even if they don't reach the } 10 \text { percent threshold to be } \\
\text { considered "large exposure." }\end{array}$ \\
\hline EC4 & $\begin{array}{l}\text { The supervisor confirms that a bank's risk management policies and processes } \\
\text { establish thresholds for acceptable concentrations of credit and require that all } \\
\text { material concentrations be reviewed and reported periodically to the Board. }\end{array}$ \\
\hline $\begin{array}{l}\text { Description and } \\
\text { findings re EC4 }\end{array}$ & $\begin{array}{l}\text { Article } 105.2 \text { of CBE } 3 / 08 \text { determines that the policies and processes must be } \\
\text { adequate to measure and control concentration risk derived from large exposures, } \\
\text { economic sector concentration, geographical region, or concentration to groups which } \\
\text { depend on the same economic activity or the same raw materials. The policies and } \\
\text { processes must be able to evaluate the use of risk mitigation techniques and seek to } \\
\text { adequately diversify their risk, according to the market and their business model, } \\
\text { monitoring their concentration and adopting corrective actions to prevent excessive } \\
\text { concentration. }\end{array}$ \\
\hline EC5 & $\begin{array}{l}\text { The supervisor regularly obtains information that enables concentrations within a } \\
\text { bank's portfolio, including sectoral, geographical and currency exposures, to be } \\
\text { reviewed. The supervisor has the power to require banks to take remedial actions in } \\
\text { cases where concentrations appear to present significant risks. }\end{array}$ \\
\hline \multirow[t]{3}{*}{$\begin{array}{l}\text { Description and } \\
\text { findings re EC5 }\end{array}$} & $\begin{array}{l}\text { See EC3 and } 4 \text {. Banks send detailed supervisory reports quarterly, and BdE can } \\
\text { require additional information when needed. Article } 67 \text { of CBE } 4 / 2004 \text { also includes } \\
\text { quarterly information on sectoral and geographic concentration. In addition, CBE } 3 / 95 \\
\text { on the CIR includes monthly information provided by banks on their exposures, } \\
\text { including economic sector and location. }\end{array}$ \\
\hline & $\begin{array}{l}\text { Article } 9(1-k) \text { and } 103 \text { of } C B E 3 / 08 \text { determine that the excesses over large exposure } \\
\text { limits are to be deducted from regulatory capital, and Article } 11 \text { of Law } 13 / 1985 \\
\text { establishes that banks that breach these limits need to take immediate action to return } \\
\text { to compliance. BdE can impose limits on the distribution of profits in that case, require } \\
\text { additional capital, order reinforcement of control or reduction of risks, operations, or } \\
\text { close branches (11-1). }\end{array}$ \\
\hline & $\begin{array}{l}\text { For economic sector concentration, the supervisor's main tool is the ICAAP process, } \\
\text { which establishes two options for a Pillar II capital add-on for sector concentration: a } \\
\text { simplified option that uses a sector concentration index (Indice de concentración } \\
\text { sectorial-ICS) and a general option for banks under IRB. }\end{array}$ \\
\hline $\begin{array}{l}\text { Additional } \\
\text { criteria }\end{array}$ & $\begin{array}{l}\text { Banks are required to adhere to the following definitions: ten per cent or more of a } \\
\text { bank's capital is defined as a large exposure; and twenty-five per cent of a bank's }\end{array}$ \\
\hline
\end{tabular}




\begin{tabular}{|c|c|}
\hline & $\begin{array}{l}\text { capital is the limit for an individual large exposure to a private sector non-bank } \\
\text { counterparty or a group of connected counterparties. }\end{array}$ \\
\hline AC1 & See EC2 \\
\hline $\begin{array}{l}\text { Description and } \\
\text { findings re AC1 }\end{array}$ & \\
\hline $\begin{array}{l}\text { Assessment of } \\
\text { Principle } 10\end{array}$ & Largely Compliant \\
\hline Comments & 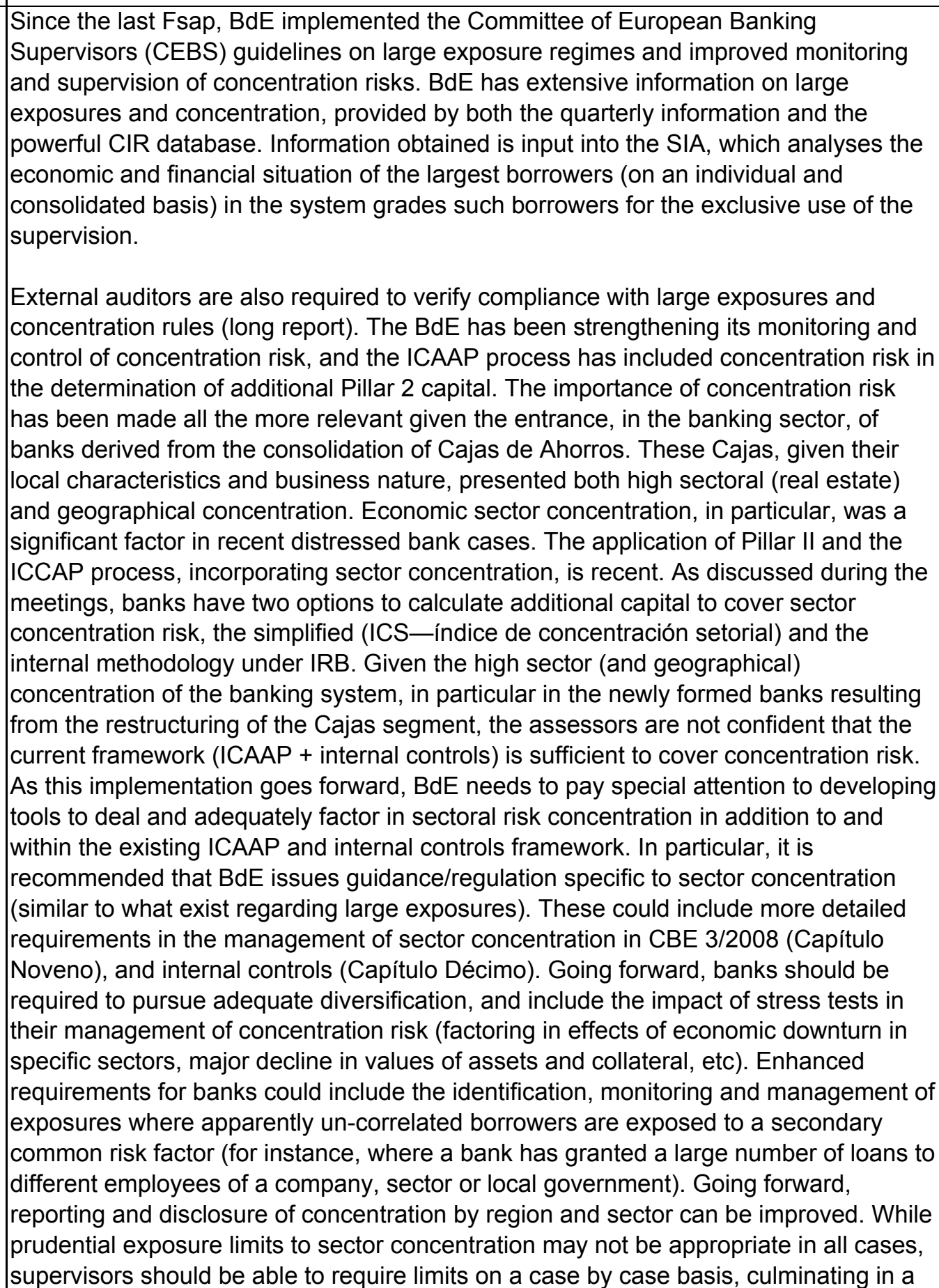 \\
\hline
\end{tabular}




\begin{tabular}{|c|c|}
\hline & $\begin{array}{l}\text { monitorable plan where the bank commits to reduce its concentration risk to an } \\
\text { acceptable level. The supervisor needs to be satisfied that the concentration risk is not } \\
\text { a cause of prudential concern. The SREP guidance can be strengthened in what } \\
\text { regards concentration risk, so that a deeper understanding of the adequacy of the } \\
\text { ICAAP capital coverage for concentration risk is sufficient. } \\
\text { Future BCP assessment updates must include the review of the CP as to ascertain the } \\
\text { effectiveness of supervision of concentration. }\end{array}$ \\
\hline Principle 11. & $\begin{array}{l}\text { Exposures to related parties. In order to prevent abuses arising from exposures (both } \\
\text { on balance sheet and off balance sheet) to related parties and to address conflict of } \\
\text { interest, supervisors must have in place requirements that banks extend exposures to } \\
\text { related companies and individuals on an arm's length basis; these exposures are } \\
\text { effectively monitored; appropriate steps are taken to control or mitigate the risks; and } \\
\text { write-offs of such exposures are made according to standard policies and processes. }\end{array}$ \\
\hline \multicolumn{2}{|l|}{$\begin{array}{l}\text { Essential } \\
\text { criteria }\end{array}$} \\
\hline EC1 & $\begin{array}{l}\text { Laws or regulations explicitly provide, or the supervisor has the power to provide, a } \\
\text { comprehensive definition of "related parties." This should consider the parties } \\
\text { identified in the footnote to the Principle. The supervisor may exercise discretion in } \\
\text { applying this definition on a case by case basis. }\end{array}$ \\
\hline $\begin{array}{l}\text { Description and } \\
\text { findings re } E C 1\end{array}$ & $\begin{array}{l}\text { Rule } 62 \text { of CBE 4/2004 provides a detailed definition of "related parties," which include } \\
\text { associated entities, legal entities and individuals related to them, or that control them, } \\
\text { or have significant influence, act in concert to exert control, share one or more council } \\
\text { or board member, controlled entities, pension funds for the entities employees or for } \\
\text { related companies, any key personnel in senior management and their families, } \\
\text { entities where such persons may have control, significant influence or voting power. } \\
\text { This definition is taken in conjunction to the discretionary capacity of the BdE to } \\
\text { declare a "single interest unit" (see EC1 CP 10). }\end{array}$ \\
\hline EC2 & $\begin{array}{l}\text { Laws, regulations or the supervisor require that exposures to related parties may not } \\
\text { be granted on more favourable terms (ie for credit assessment, tenor, interest rates, } \\
\text { amortisation schedules, requirement for collateral) than corresponding exposures to } \\
\text { non-related counterparties. }\end{array}$ \\
\hline $\begin{array}{l}\text { Description and } \\
\text { findings re EC2 }\end{array}$ & $\begin{array}{l}\text { Annex IX of CBE } 4 / 2004 \text {, Section I.1, establishes that credit risk policies and } \\
\text { processes must define the policies for related party lending. In particular, conditions } \\
\text { and terms for lending to related parties must be similar to those applicable to loans to } \\
\text { non-related parties in the same risk category. } \\
\text { Article } 67-2 \text { of CBE } 4 / 2004 \text { also states that banks must only disclose that such } \\
\text { transactions were carried in market terms when they can prove it. }\end{array}$ \\
\hline EC3 & $\begin{array}{l}\text { The supervisor requires that transactions with related parties and the write-off of } \\
\text { related-party exposures exceeding specified amounts or otherwise posing special } \\
\text { risks are subject to prior approval by the bank's Board. The supervisor requires that } \\
\text { Board members with conflicts of interest are excluded from the approval process. }\end{array}$ \\
\hline $\begin{array}{l}\text { Description and } \\
\text { findings re EC3 }\end{array}$ & $\begin{array}{l}\text { See EC2. The credit policies for related party lending need to be approved by the } \\
\text { Board (Annex IX of CBE } 4 / 2004 \text {, Section I.1) There is no specific requirement that all } \\
\text { related party lending needs prior approval of the board. On one subcategory of } \\
\text { related party lending, which is lending to senior management and board members, } \\
\text { Article } 119.1 \text { of CBE } 3 / 08 \text { requires approval by the Board, without the intervention of } \\
\text { the interested party/member, and must also be submitted for prior approval of BdE. }\end{array}$ \\
\hline
\end{tabular}




\begin{tabular}{|c|c|}
\hline & $\begin{array}{l}\text { The operation will be tacitly considered approved if the BdE does not communicate } \\
\text { with the entity in } 15 \text { days. }\end{array}$ \\
\hline EC4 & $\begin{array}{l}\text { The supervisor requires that banks have policies and processes in place to prevent } \\
\text { persons benefiting from the exposure and/or persons related to such a person from } \\
\text { being part of the process of granting and managing the exposure. }\end{array}$ \\
\hline $\begin{array}{l}\text { Description and } \\
\text { findings re EC4 }\end{array}$ & $\begin{array}{l}\text { See EC3. Except for lending to senior management, there are not such requirements } \\
\text { established by laws or regulations. }\end{array}$ \\
\hline EC5 & $\begin{array}{l}\text { Laws or regulations set, or the supervisor has the power to set on a general or case by } \\
\text { case basis, limits for exposures to related parties, to deduct such exposures from } \\
\text { capital when assessing capital adequacy, or to require collateralisation of such } \\
\text { exposures. When limits are set on aggregate exposures to related parties those are at } \\
\text { least as strict as those for single counterparties, or groups of connected } \\
\text { counterparties. }\end{array}$ \\
\hline $\begin{array}{l}\text { Description and } \\
\text { findings re EC5 }\end{array}$ & $\begin{array}{l}\text { There are no specific limits set by laws, regulations or the supervisor on exposures to } \\
\text { related parties. CBE } 3 / 2008 \text {, Article } 102 \text {, does include in the aggregation of large } \\
\text { exposures (for the calculation of the } 25 \text { percent large exposures limit-see CP 10) } \\
\text { most related exposures, i.e., senior management of the entity and companies } \\
\text { controlled by them, but not all related party exposures as defined in Rule } 62 \text { of CBE } \\
4 / 2004 \text {. }\end{array}$ \\
\hline EC6 & $\begin{array}{l}\text { The supervisor requires banks to have policies and processes to identify individual } \\
\text { exposures to related parties as well as the total amount of such exposures, and to } \\
\text { monitor and report on them through an independent credit review process. The } \\
\text { supervisor confirms that exceptions to policies, processes and limits are reported to } \\
\text { the appropriate level of senior management and, if necessary, to the Board, for timely } \\
\text { action. The supervisor also confirms that senior management monitors related party } \\
\text { transactions on an ongoing basis, and that the Board also provides oversight of these } \\
\text { transactions. }\end{array}$ \\
\hline $\begin{array}{l}\text { Description and } \\
\text { findings re EC6 }\end{array}$ & $\begin{array}{l}\text { There are no specific requirements for related party exposures. Internal controls } \\
\text { regulation (Regulation } 72 \text { CBE } 4 / 2004 \text { ) determines that banks should follow with } \\
\text { maximum attention their risk, in particular the risk taken in intra-group operations. The } \\
\text { general credit risk policy (CBE } 3 / 2008 \text { Article } 105 \text { ) requires the lending must be based } \\
\text { on solid criteria, and lending procedures must be clearly established (on credit risk } \\
\text { management, see CP } 8 \text { ), and that related party should be considered in the } \\
\text { management of concentration risk. For lending to senior management a prior } \\
\text { authorization of the Board and BdE is required. } \\
\text { Also, not specifically on large exposures, the credit policy approved by the board must } \\
\text { detail which circumstances exceptional credit transactions could take place. (Annex IX } \\
\text { CBE } 4 / 2004 \text { - I.1.f). }\end{array}$ \\
\hline EC7 & $\begin{array}{l}\text { The supervisor obtains and reviews information on aggregate exposures to related } \\
\text { parties. }\end{array}$ \\
\hline $\begin{array}{l}\text { Description and } \\
\text { findings re EC7 }\end{array}$ & $\begin{array}{l}\text { Half-yearly, banks need to inform BdE a list of people who should qualify as related } \\
\text { parties to whom loans have been extended. (Article } 119.2 \text { of CBE 3/08). Monthly } \\
\text { information on all loans is also provided through CIR. Based on this information; BdE } \\
\text { also monitors loans to senior management and related companies (Article } 102^{\mathrm{a}} .2 \text {. } \\
\text { CBE 3/2008). Information from SIA (see above) is also available. }\end{array}$ \\
\hline $\begin{array}{l}\text { Assessment of } \\
\text { Principle } 11\end{array}$ & Largely Compliant \\
\hline
\end{tabular}




\begin{tabular}{|c|c|}
\hline Comments & 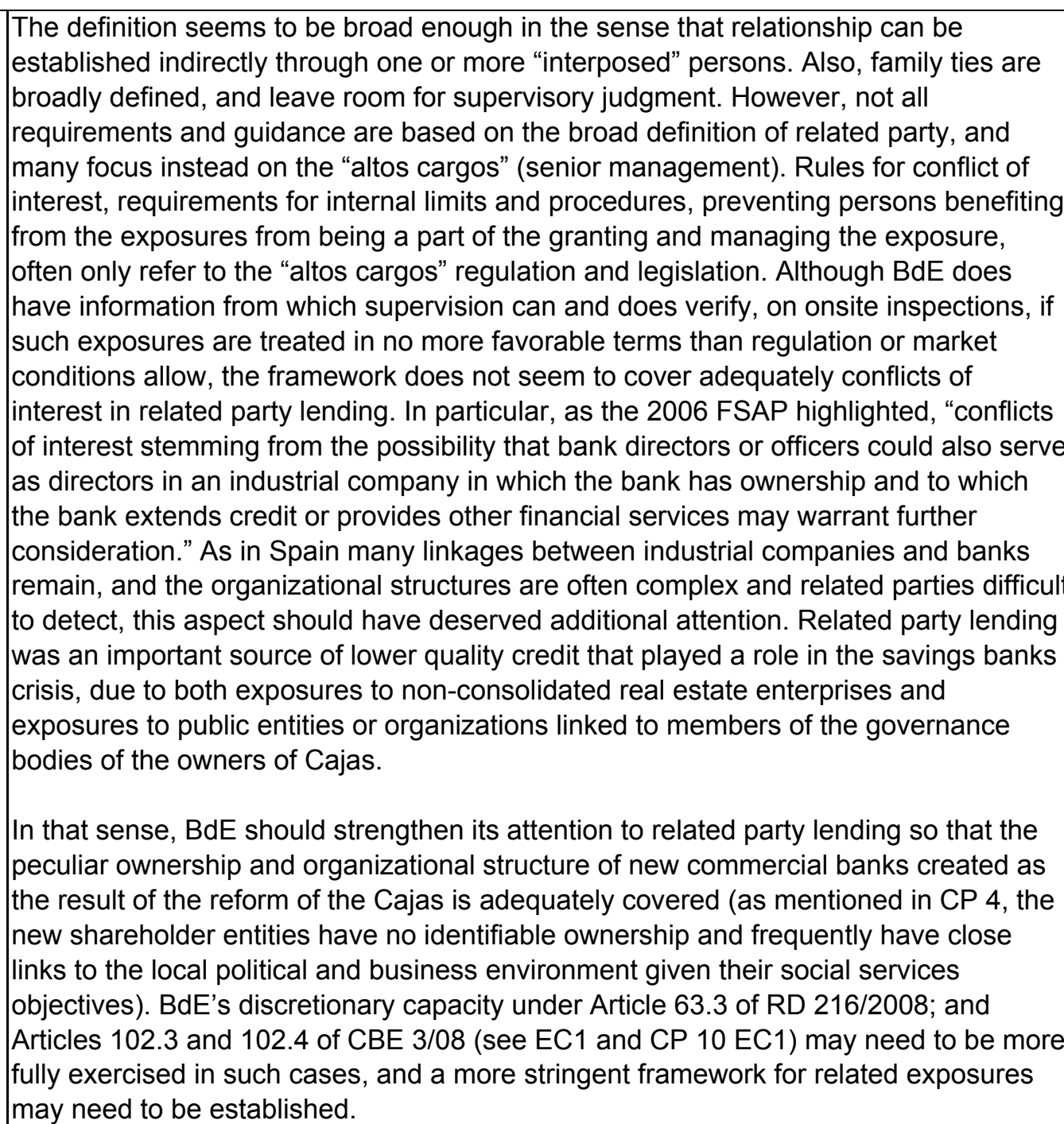 \\
\hline Principle 12. & $\begin{array}{l}\text { Country and transfer risks. Supervisors must be satisfied that banks have adequate } \\
\text { policies and processes for identifying, measuring, monitoring and controlling country } \\
\text { risk and transfer risk in their international lending and investment activities, and for } \\
\text { maintaining adequate provisions and reserves against such risks. }\end{array}$ \\
\hline \multicolumn{2}{|l|}{$\begin{array}{l}\text { Essential } \\
\text { criteria }\end{array}$} \\
\hline EC1 & $\begin{array}{l}\text { The supervisor determines that a bank's policies and processes give due regard to the } \\
\text { identification, measurement, monitoring and control of country risk and transfer risk. } \\
\text { Exposures are identified and monitored on an individual country basis (in addition to } \\
\text { the end-borrower/end-counterparty basis). Banks are required to monitor and evaluate } \\
\text { developments in country risk and in transfer risk and apply appropriate } \\
\text { countermeasures. }\end{array}$ \\
\hline $\begin{array}{l}\text { Description and } \\
\text { findings re EC1 }\end{array}$ & $\begin{array}{l}\text { Annex IX of CEB } 4 \text { determines that banks must have policies, methods and processes } \\
\text { applicable to lending activities and off balance sheet risks, as well as the identification } \\
\text { of deterioration and the measurement of needed coverage for credit risk, not only } \\
\text { based on client by also on country risk. Article } 8 \text { details the definition of country and } \\
\text { transfer risk. Exposures are identified and monitored on an individual country basis } \\
\text { (see EC2). }\end{array}$ \\
\hline
\end{tabular}




\begin{tabular}{|c|c|}
\hline & $\begin{array}{l}\text { The implementation of Pillar } 2 \text { and stress testing guidelines also include identification, } \\
\text { monitor and mitigation of country risk. (see CP 7). }\end{array}$ \\
\hline EC2 & $\begin{array}{l}\text { The supervisor confirms that banks have information systems, risk management } \\
\text { systems and internal control systems that accurately monitor and report country } \\
\text { exposures and ensure adherence to established country exposure limits. }\end{array}$ \\
\hline $\begin{array}{l}\text { Description and } \\
\text { findings re EC2 }\end{array}$ & $\begin{array}{l}\text { Annex IX CBE 4/2004.is very detailed on country risk. In addition, regulations } 67 \text { and } \\
69 \text { of CBE 4/2004 mandate banks to send to BdE quarterly information on solo and } \\
\text { consolidated basis, of exposures by country group and by country. CBE can also } \\
\text { require ad-hoc information consolidated by geographic region. }\end{array}$ \\
\hline EC3 & $\begin{array}{l}\text { There is supervisory oversight of the setting of appropriate provisions against country } \\
\text { risk and transfer risk. There are different international practices which are all } \\
\text { acceptable as long as they lead to risk-based results. These include: } \\
\text { - The supervisor (or some other official authority) decides on appropriate minimum } \\
\text { provisioning by setting fixed percentages for exposures to each country. } \\
\text { - The supervisor (or some other official authority) sets percentage ranges for each } \\
\text { country, and the banks may decide, within these ranges, which provisioning to } \\
\text { apply for the individual exposures. } \\
\text { - The bank itself (or some other body such as the national bankers' association) } \\
\text { sets percentages or guidelines or even decides for each individual loan on the } \\
\text { appropriate provisioning. The provisioning will then be judged by the external } \\
\text { auditor and/or by the supervisor. }\end{array}$ \\
\hline $\begin{array}{l}\text { Description and } \\
\text { findings re EC3 }\end{array}$ & $\begin{array}{l}\text { Provisions against country risk are set in regulation CBE } 4 / 2004 \text {, annex IX, } 9-12 \text {. It } \\
\text { requires Banks to classify their exposures per country risk, grouping the exposures in } \\
\text { for } 6 \text { categories in crescent order of risk. Exposures to group six countries are } \\
\text { considered of remote recovery and must be written off. The classification needs to be } \\
\text { verifiable criteria, based on the payment history, external and internal debt situation, } \\
\text { economic situation, monetary and balance of payment indicators, vulnerability (for } \\
\text { instance, based on undiversified exports), market indications, external ratings, etc. tem } \\
30 \text { of the Annex establishes the minimum levels of provision for country risk: Group } 5 \text {, } \\
83,50 \text { percent; Group } 4,22,80 \text { percent; and Group } 3 ; 10,10 \text { percent. Provisions for } \\
\text { interbank exposures with a maturity shorter than } 3 \text { months in countries } 3 \text { or } 4 \text { may be } \\
\text { reduced in half provided there is no overdue payment or refinanced transaction. } \\
\text { Given the international exposure of its major banks, BdE has developed a continuous } \\
\text { analysis of country risk, with a special focus on Latin America. A specialized Country } \\
\text { Risk Unit of the General Associate Directorate of International Affairs studies and } \\
\text { monitors the political and economic developments and makes an internal assessment } \\
\text { of country risk for BdE's use. The information received from the institutions with the } \\
\text { classification of the different countries is checked against that assessment to control } \\
\text { for discrepancies. When found, supervisors require the classifications to be revised. }\end{array}$ \\
\hline EC4 & $\begin{array}{l}\text { The supervisor obtains and reviews sufficient information on a timely basis on the } \\
\text { country risk and transfer risk of individual banks. }\end{array}$ \\
\hline $\begin{array}{l}\text { Description and } \\
\text { findings re EC4 }\end{array}$ & See EC2 and EC3. \\
\hline $\begin{array}{l}\text { Assessment of } \\
\text { Principle } 12\end{array}$ & Compliant \\
\hline Comment & \\
\hline
\end{tabular}




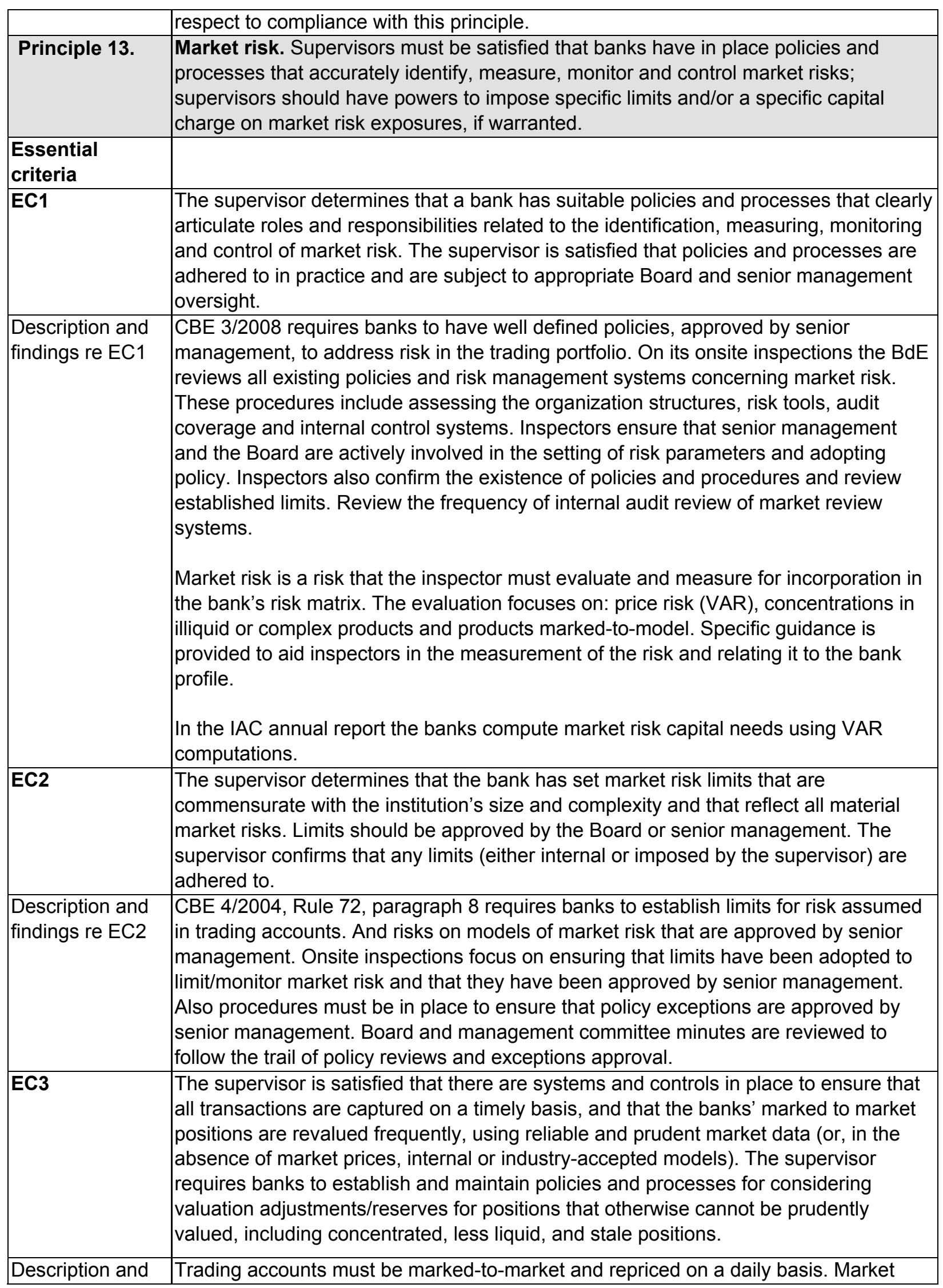




\begin{tabular}{|c|c|}
\hline findings re EC3 & $\begin{array}{l}\text { values established by models must be confirmed and tested. Internal audit must } \\
\text { review the risk management process and compliance with limits. Processes must be in } \\
\text { place to ensure the validity of market prices. } \\
\text { During onsite inspections the following takes place: Ensure that all transactions are } \\
\text { booked timely, traders only book transactions that comply with policies, recordkeeping } \\
\text { takes place simultaneous with position taken, the monitoring system reports } \\
\text { exceptions and market swings above a certain threshold, confirm daily mark-to- } \\
\text { market, determine adequacy of pricing of positions for which there is not a market. }\end{array}$ \\
\hline EC4 & $\begin{array}{l}\text { The supervisor determines that banks perform scenario analysis, stress testing and } \\
\text { contingency planning, as an appropriate, and periodic validation or testing of the } \\
\text { systems used to measure market risk. The supervisor confirms that the approaches } \\
\text { are integrated into risk management policies and processes, and results are taken into } \\
\text { account in the bank's risk-taking strategy. }\end{array}$ \\
\hline $\begin{array}{l}\text { Description and } \\
\text { findings re EC4 }\end{array}$ & $\begin{array}{l}\text { CBE } 3 / 2008 \text { requires stress testing and senior management must review results. } \\
\text { Stress testing must be performed at adequate frequency, as defined by bank policies. } \\
\text { Results must be backtested. The BdE has expert staff to review models and stress } \\
\text { testing. } \\
\text { During onsite inspections, the BdE ensures compliance with the June } 2006 \text { BCBS } \\
\text { paper on stress testing. }\end{array}$ \\
\hline \multicolumn{2}{|l|}{\begin{tabular}{|l|} 
Additional \\
criteria
\end{tabular}} \\
\hline AC1 & $\begin{array}{l}\text { The supervisor requires that market data used to value trading book positions are } \\
\text { verified by a function independent of the lines of business. To the extent that the bank } \\
\text { relies on modeling for the purposes of valuation, the bank is required to ensure that } \\
\text { the model is independently tested. }\end{array}$ \\
\hline $\begin{array}{l}\text { Description and } \\
\text { findings re AC1 }\end{array}$ & $\begin{array}{l}\text { CBE } 3 / 2008 \text {, Rule } 84 \text {, requires that the risk management policies clearly establish the } \\
\text { roles of independent areas from the position, line management areas to monitor, test } \\
\text { and validate the bank models and the data that goes in them. These areas are } \\
\text { reviewed during onsite inspections. }\end{array}$ \\
\hline \begin{tabular}{|l|} 
Assessment of \\
Principle 13 \\
\end{tabular} & Compliant \\
\hline \multicolumn{2}{|l|}{ Comments } \\
\hline Principle 14. & $\begin{array}{l}\text { Liquidity risk. Supervisors must be satisfied that banks have a liquidity management } \\
\text { strategy that takes into account the risk profile of the institution, with prudent policies } \\
\text { and processes to identify, measure, monitor and control liquidity risk, and to manage } \\
\text { liquidity on a day-to-day basis. Supervisors require banks to have contingency plans } \\
\text { for handling liquidity problems. }\end{array}$ \\
\hline \multicolumn{2}{|l|}{$\begin{array}{l}\text { Essential } \\
\text { criteria }\end{array}$} \\
\hline EC1 & $\begin{array}{l}\text { The supervisor sets liquidity guidelines for banks. These guidelines take into } \\
\text { consideration undrawn commitments and other off-balance sheet liabilities, as well as } \\
\text { existing on-balance sheet liabilities. }\end{array}$ \\
\hline $\begin{array}{l}\text { Description and } \\
\text { findings re } E C 1\end{array}$ & $\begin{array}{l}\text { Banks are required to establish adequate internal policies and controls to ensure that } \\
\text { sufficient information is available, both at individual and consolidated level, to assess } \\
\text { the liquidity position in the short, medium and long-term. Liquidity positions should } \\
\text { include off-balance-sheet positions and take into consideration the funding structure in } \\
\text { relation to the markets in which the institution operates. Currently, BdE does not } \\
\text { impose quantitative limits. Guidelines reflect BCBS guidelines. }\end{array}$ \\
\hline
\end{tabular}




\begin{tabular}{|c|c|}
\hline & $\begin{array}{l}\text { BdE monitors bank's funding gaps for different time buckets and it monitors they have } \\
\text { enough liquidity to cover one-week, one-month and three-month buckets. Banks } \\
\text { should be able to cover these buckets if wholesale market close to the bank. } \\
\text { For the annual IAC report banks are required to report the the ratios and other } \\
\text { monitoring metrics that are provided to key management. Additionally, loan to deposit } \\
\text { ratios and cash flow gaps are collected and monitored. Parameters on how these } \\
\text { values measure risk and at what levels additional risk management practices are } \\
\text { required. }\end{array}$ \\
\hline EC2 & $\begin{array}{l}\text { The supervisor confirms that banks have a liquidity management strategy, as well as } \\
\text { policies and processes for managing liquidity risk, which have been approved by the } \\
\text { Board. The supervisor also confirms that the Board has an oversight role in ensuring } \\
\text { that policies and processes for risk-taking are developed to monitor, control and limit } \\
\text { liquidity risk, and that management effectively implements such policies and } \\
\text { processes. }\end{array}$ \\
\hline $\begin{array}{l}\text { Description and } \\
\text { findings re EC2 }\end{array}$ & $\begin{array}{l}\text { CBE } 3 / 2008 \text { requires the Board of Directors to ensure that risk management policies } \\
\text { and controls are adequate to monitor liquidity. Practices and policies have to be } \\
\text { tailored to the bank's risk. } \\
\text { The BdE monitors liquidity using the SABER approach. Liquidity risk is one of the key } \\
\text { risks that have to be scored into the matrix. In preparing the matrix the inspector } \\
\text { determines whether the level of risk is high and rates it which will result in increased } \\
\text { monitoring. }\end{array}$ \\
\hline EC3 & $\begin{array}{l}\text { The supervisor determines that a bank's senior management has defined (or } \\
\text { established) appropriate policies and processes to monitor, control and limit liquidity } \\
\text { risk; implements effectively such policies and processes; and understands the nature } \\
\text { and level of liquidity risk being taken by the bank. }\end{array}$ \\
\hline $\begin{array}{l}\text { Description and } \\
\text { findings re EC3 }\end{array}$ & $\begin{array}{l}\text { Liquidity risk is included within the ICAAP requirements and therefore, the Board and } \\
\text { senior management have to take full responsibility for its management. Annually the } \\
\text { banks must file the IAC that includes their assessment of liquidity. The BdE includes } \\
\text { the IAC information in its liquidity assessment. } \\
\text { During onsite assessments, inspectors review Board minutes, policy and limits } \\
\text { established to control risk. Inspectors also ensure that limits exceeded are reported to } \\
\text { the Board and senior management. }\end{array}$ \\
\hline EC4 & $\begin{array}{l}\text { The supervisor requires banks to establish policies and processes for the ongoing } \\
\text { measurement and monitoring of net funding requirements. The policies and processes } \\
\text { include considering how other risks (e.g., credit, market and operational risk) may } \\
\text { impact the bank's overall liquidity strategy, and require an analysis of funding } \\
\text { requirements under alternative scenarios, diversification of funding sources, a review } \\
\text { of concentration limits, stress testing, and a frequent review of underlying assumptions } \\
\text { to determine that they continue to be valid. }\end{array}$ \\
\hline $\begin{array}{l}\text { Description and } \\
\text { findings re EC4 }\end{array}$ & $\begin{array}{l}\text { Banks are required to report, not only cash and securities flows but also off balance } \\
\text { sheet liabilities and possible sources of contingent risk. Banks are also required to } \\
\text { report concentration indicators. As part of the ICAAP banks must evaluate liquidity risk } \\
\text { in relation to other risks and include the liquidity risk in its internal capital needs } \\
\text { computations. Banks are expected to conduct stress tests to determine the impact of a } \\
\text { market crisis or an idiosyncratic crisis. }\end{array}$ \\
\hline EC5 & The supervisor obtains sufficient information to identify those institutions carrying out \\
\hline
\end{tabular}




\begin{tabular}{|c|c|}
\hline & $\begin{array}{l}\text { significant foreign currency liquidity transformation. Where a bank or banking group's } \\
\text { foreign currency business, either directly, or indirectly through lending in foreign } \\
\text { exchange to domestic borrowers, is significant, or where a particular currency in which } \\
\text { the bank has material exposure is experiencing problems, the supervisor requires the } \\
\text { bank to undertake separate analysis of its strategy for each currency individually and, } \\
\text { where appropriate, set and regularly review limits on the size of its cash flow } \\
\text { mismatches for foreign currencies in aggregate and for each significant individual } \\
\text { currency. }\end{array}$ \\
\hline $\begin{array}{l}\text { Description and } \\
\text { findings re EC5 }\end{array}$ & $\begin{array}{l}\text { Liquidity is monitored in Euros and there is no requirement that foreign exchange } \\
\text { liquidity risk be segregated. Banks with significant foreign currency risk (more than } \\
5 \text { percent of assets/liability) are required to monitor such positions, and the BdE } \\
\text { monitors bank internal reports closely. Plans are to institute reporting to BdE on a } \\
\text { standard format for banks with significant exposure. }\end{array}$ \\
\hline EC6 & $\begin{array}{l}\text { The supervisor determines that banks have contingency plans in place for handling } \\
\text { liquidity problems, including informing the supervisor. }\end{array}$ \\
\hline $\begin{array}{l}\text { Description and } \\
\text { findings re EC6 }\end{array}$ & $\begin{array}{l}\text { CBE 3/2008 requires banks to undertake stress tests and develop effective } \\
\text { contingency plans, based on the outcome of such stress tests. Therefore, banks are } \\
\text { required to develop detailed contingency plans to handle liquidity risk. These plans are } \\
\text { discussed with BdE. Also the banks and BdE meet annually to discuss the IAC. }\end{array}$ \\
\hline \multicolumn{2}{|l|}{$\begin{array}{l}\text { Additional } \\
\text { criteria }\end{array}$} \\
\hline AC1 & $\begin{array}{l}\text { The supervisor determines that, where a bank conducts its business in multiple } \\
\text { currencies, foreign currency liquidity strategy is separately stress-tested, and the } \\
\text { results of such tests are a factor in determining the appropriateness of mismatches. }\end{array}$ \\
\hline $\begin{array}{l}\text { Description and } \\
\text { findings re } A C 1\end{array}$ & $\begin{array}{l}\text { Only the large banks conduct their business in multiple currencies. As a general } \\
\text { practice, the financial autonomy (foreign subsidiaries are self-funded in the local } \\
\text { market) model ensures that each foreign subsidiary is adequately funded and has } \\
\text { liquid assets. }\end{array}$ \\
\hline AC2 & $\begin{array}{l}\text { The supervisor confirms that banks periodically review their efforts to establish and } \\
\text { maintain relationships with liability holders, maintain the diversification of liabilities, and } \\
\text { aim to ensure their capacity to sell assets. }\end{array}$ \\
\hline $\begin{array}{l}\text { Description and } \\
\text { findings re AC2 }\end{array}$ & $\begin{array}{l}\text { As part of the supervisory program, banks are assessed taking into account the } \\
\text { diversification of their liabilities and their access to markets. This focus has been } \\
\text { intensified since the beginning of the crisis and supervisors have weekly or, if } \\
\text { necessary, more frequent meetings and conference calls with the banks to be } \\
\text { informed about investors' perceptions and the market situation. }\end{array}$ \\
\hline $\begin{array}{l}\text { Assessment of } \\
\text { Principle } 14\end{array}$ & Compliant \\
\hline Comments & $\begin{array}{l}\text { The assessors had access to the supervisor's intense monitoring of liquidity risks in } \\
\text { the banks and in the system, which include discussions of strategies and sustainability } \\
\text { of funding with the relevant banks, in particular given the delicate situation of general } \\
\text { liquidity and funding in Europe. The assessors note that the current international } \\
\text { liquidity standards are being modified, and observe the authorities have been actively } \\
\text { discussing with the banks their implementation and consequences. Authorities are } \\
\text { recommended to continue the intense monitoring of liquidity risk and liquidity risk } \\
\text { management aimed at sustainability and resilience in the longer term. It must be noted } \\
\text { that Spain in } 2011 \text { introduced regulation requiring a higher level of common equity } \\
\text { capital of banks that rely on wholesale funding. (see CP 6). }\end{array}$ \\
\hline Principle 15. & $\begin{array}{l}\text { Operational risk. Supervisors must be satisfied that banks have in place risk } \\
\text { management policies and processes to identify, assess, monitor and control/mitigate } \\
\text { operational risk. These policies and processes should be commensurate with the size }\end{array}$ \\
\hline
\end{tabular}




\begin{tabular}{|c|c|}
\hline & and complexity of the bank. \\
\hline \multicolumn{2}{|l|}{$\begin{array}{l}\text { Essential } \\
\text { criteria }\end{array}$} \\
\hline EC1 & $\begin{array}{l}\text { The supervisor requires individual banks to have in place risk management policies } \\
\text { and processes to identify, assess, monitor and mitigate operational risk. These } \\
\text { policies and processes are adequate for the size and complexity of the bank's } \\
\text { operations, and the supervisor confirms that they are periodically adjusted in the light } \\
\text { of the bank's changing risk profile and external market developments. }\end{array}$ \\
\hline $\begin{array}{l}\text { Description and } \\
\text { findings re EC1 }\end{array}$ & $\begin{array}{l}\text { See CP } 7 \text { for general risk management requirements. In particular, CBE } 3 / 2008, X \text { and } \\
\text { rule } 105.2 \text {.d. (vi) determines that policies and processes of risk management and } \\
\text { internal control must be adequate to evaluate and manage the exposure to operational } \\
\text { risk, including exposure to events of low frequency but high severity. Banks must } \\
\text { determine which are the sources and factors that generate operational risk given their } \\
\text { procedures and business. It also requires written emergency and business continuity } \\
\text { plans that assure loss are limited in the case of grave incidents. } \\
\text { CBE } 3 / 2008 \text {, Chapter VIII establishes specific capital requirements related to } \\
\text { operational risk. Rules } 98.2 \text { and } 97.2 \text { include different measurement processes } \\
\text { requirements for standard and advanced methods. Rule } 108 \text { includes the supervisory } \\
\text { review of ICAAP process, in which operational risk is included. Operational risk is one } \\
\text { of the inputs of the supervisory risk matrix SABER (see CP } 19 \text { and 20). }\end{array}$ \\
\hline EC2 & $\begin{array}{l}\text { The supervisor requires that banks' strategies, policies and processes for the } \\
\text { management of operational risk have been approved and are periodically reviewed by } \\
\text { the Board. The supervisor also requires that the Board oversees management in } \\
\text { ensuring that these policies and processes are implemented effectively. }\end{array}$ \\
\hline $\begin{array}{l}\text { Description and } \\
\text { findings re EC2 }\end{array}$ & $\begin{array}{l}\text { See EC1. The risk management policy for operational risk needs to be approved and } \\
\text { annually reviewed by the Board. }\end{array}$ \\
\hline EC3 & $\begin{array}{l}\text { The supervisor is satisfied that the approved strategy and significant policies and } \\
\text { processes for operational risk are implemented effectively by management. }\end{array}$ \\
\hline $\begin{array}{l}\text { Description and } \\
\text { findings re EC3 }\end{array}$ & See EC1. \\
\hline EC4 & $\begin{array}{l}\text { The supervisor reviews the quality and comprehensiveness of the bank's business } \\
\text { resumption and contingency plans to satisfy itself that the bank is able to operate as a } \\
\text { going concern and minimise losses, including those that may arise from disturbances } \\
\text { to payment and settlement systems, in the event of severe business disruption. }\end{array}$ \\
\hline $\begin{array}{l}\text { Description and } \\
\text { findings re EC4 }\end{array}$ & $\begin{array}{l}\text { As described in EC1, CBE } 3 / 2008, \text { Rule } 105,2 . d . v i) \text {, requires entities to have } \\
\text { emergency and contingency plans. In their supervisory action, BdE inspectors have } \\
\text { used a set of internal criteria to assess the adequacy of such continuity plans, such as } \\
\text { the existence of a map of critical processes that is reviewed and updated at least } \\
\text { every three years, that the plan includes all the applications needed for the business } \\
\text { core, has updated documentation and is tested yearly. The tests need to be recorded } \\
\text { and the problems detected are tracked down. Backup procedures ensure recovery } \\
\text { with no date loss, primary and secondary data centers must be geographically } \\
\text { allocated in a way that makes unlikely both unavailable for the same reason, Recovery } \\
\text { Time Objective must be lower than } 12 \text { hours. The plans must define sceneries and } \\
\text { recovery strategies, include activation criteria, and must be available in different } \\
\text { supports and locations and contain detailed instructions in case of an incident would } \\
\text { happen. }\end{array}$ \\
\hline EC5 & $\begin{array}{l}\text { The supervisor determines that banks have established appropriate information } \\
\text { technology policies and processes that address areas such as information security }\end{array}$ \\
\hline
\end{tabular}




\begin{tabular}{|c|c|}
\hline & $\begin{array}{l}\text { and system development, and have made investments in information technology } \\
\text { commensurate with the size and complexity of operations. }\end{array}$ \\
\hline $\begin{array}{l}\text { Description and } \\
\text { findings re EC5 }\end{array}$ & $\begin{array}{l}\text { Spanish banks are heavy on IT, and the BdE has developed specific guidance on } \\
\text { technologic policies, and counts with a specialized IT team of } 31 \text { people. Most are } \\
\text { assigned to the operational divisions, who assist in IT inspections, and there is one } \\
\text { specialized division with } 4 \text { IT specialists who do IT inspection in cooperation with the } \\
\text { operational divisions. IT processes and policies are required to include loss control; an } \\
\text { annual technology budget and formal procedures of approval, tracking, monitoring and } \\
\text { control, cost attribution to subsidiaries and procedures and controls for suppliers. } \\
\text { Banks must have a logic security unit, updated internal regulation on security; } \\
\text { procedures to control the access to the resources, regular security checking, means to } \\
\text { avoid the copy of confidential data, adequately maintained firewalls, supervision of } \\
\text { outsourced activities by the security unit. } \\
\text { There are also requirements for System development, such as automatic } \\
\text { reconciliations between business applications, management applications and } \\
\text { accountability, analysis of database, infrastructure and applications map, separated } \\
\text { environments for development, test and production, where data are accessible only } \\
\text { within each environment. }\end{array}$ \\
\hline EC6 & $\begin{array}{l}\text { The supervisor requires that appropriate reporting mechanisms are in place to keep } \\
\text { the supervisor apprised of developments affecting operational risk at banks in their } \\
\text { jurisdictions. }\end{array}$ \\
\hline & $\begin{array}{l}\text { Rule } 122 \text { of CBE } 3 / 2008 \text { includes regulation on annual supervisory returns related to } \\
\text { operational risk (RP41, RP 43), including losses arising from operational risk. Part of } \\
\text { that information, and information on operational risk management, is mandatorily } \\
\text { made public according to rule } 115 \mathrm{CBE} 3 / 2008 \text {.For institutions with ongoing on site } \\
\text { supervision, the monitoring of operational risk is constant. }\end{array}$ \\
\hline EC7 & $\begin{array}{l}\text { The supervisor confirms that legal risk is incorporated into the operational risk } \\
\text { management processes of the bank. }\end{array}$ \\
\hline $\begin{array}{l}\text { Description and } \\
\text { findings re EC7 }\end{array}$ & $\begin{array}{l}\text { R216/2008, Rule } 58.2 \text { explicitly includes legal risk in the definition of operational risk. } \\
\text { In additional, legal risk is a separate input in the operational risk matrix used by BdE in } \\
\text { the SABER. }\end{array}$ \\
\hline EC8 & $\begin{array}{l}\text { The supervisor determines that banks have established appropriate policies and } \\
\text { processes to assess, manage and monitor outsourced activities. } \\
\text { The outsourcing risk management program should cover: } \\
\text { - } \quad \text { conducting appropriate due diligence for selecting potential service providers; } \\
\text { - } \quad \text { structuring the outsourcing arrangement; } \\
\text { - } \quad \text { ensuring an effective control environment; and } \\
\text { - establishing viable contingency planning. } \\
\text { Outsourcing policies and processes should require the institution to have } \\
\text { comprehensive contracts and/or service level agreements with a clear allocation of } \\
\text { responsibilities between the outsourcing provider and the bank. }\end{array}$ \\
\hline $\begin{array}{l}\text { Description and } \\
\text { findings re EC8 }\end{array}$ & $\begin{array}{l}\text { Circular } 3 / 2008, \text { Rule } 105.4 \text { establishes general requirements for outsourcing by } \\
\text { Spanish credit institutions. Banks can only outsource their general services to third } \\
\text { parties, if some conditions are observed. Only ancillary services can be outsourced } \\
\text { (collection of deposits and credit underwriting cannot be outsourced), internal controls }\end{array}$ \\
\hline
\end{tabular}




\begin{tabular}{|c|c|}
\hline & $\begin{array}{l}\text { cannot be outsourced, outsourcing cannot hinder BdE's supervision (all contract must } \\
\text { include unfettered access of BdE to installations, people, systems, documents, etc). } \\
\text { Any outsourced activity continues to be responsibility of the Board and senior } \\
\text { management, and must be included and approved in the risk management process. } \\
\text { Outsourced services must be contracted based on the quality, stability and } \\
\text { experience, as well as the level of control and dependence that the contract will entail. } \\
\text { Outsourcing must be reflected in the contingency and business continuity plans. BdE } \\
\text { may impose additional restrictions on outsourcing on a case by case basis. }\end{array}$ \\
\hline \multicolumn{2}{|l|}{$\begin{array}{l}\text { Additional } \\
\text { criteria }\end{array}$} \\
\hline AC1 & $\begin{array}{l}\text { The supervisor determines that the risk management policies and processes address } \\
\text { the major aspects of operational risk, including an appropriate operational risk } \\
\text { framework that is applied on a group-wide basis. The policies and processes should } \\
\text { include additional risks prevalent in certain operationally intensive businesses, such as } \\
\text { custody and correspondent banking, and should cover periods when operational risk } \\
\text { could increase. }\end{array}$ \\
\hline $\begin{array}{l}\text { Description and } \\
\text { findings re AC1 }\end{array}$ & $\begin{array}{l}\text { See EC1. The requirements are applied on solo and consolidated basis. In addition, } \\
\text { CBE } 4 / 2004 \text {, Rule } 72.9 \text {, establishes very specific managerial control requirements and } \\
\text { information over custody activities. }\end{array}$ \\
\hline $\begin{array}{l}\text { Assessment of } \\
\text { Principle } 15\end{array}$ & Compliant \\
\hline Comments & $\begin{array}{l}\text { Assessors were given access to the supervisory working documents and systems with } \\
\text { respect to compliance with this principle. }\end{array}$ \\
\hline Principle 16. & $\begin{array}{l}\text { IRR in the banking book. Supervisors must be satisfied that banks have effective } \\
\text { systems in place to identify, measure, monitor and control IRR in the banking book, } \\
\text { including a well defined strategy that has been approved by the Board and } \\
\text { implemented by senior management; these should be appropriate to the size and } \\
\text { complexity of such risk. }\end{array}$ \\
\hline \multicolumn{2}{|l|}{$\begin{array}{l}\text { Essential } \\
\text { criteria }\end{array}$} \\
\hline EC1 & $\begin{array}{l}\text { The supervisor determines that a bank's Board approves, and periodically reviews, the } \\
\text { IRR strategy and policies and processes for the identification, measuring, monitoring } \\
\text { and control of IRR. The supervisor also determines that management ensures that the } \\
\text { IRR strategy, policies and processes are developed and implemented. }\end{array}$ \\
\hline $\begin{array}{l}\text { Description and } \\
\text { findings re EC1 }\end{array}$ & $\begin{array}{l}\text { Law 26/1988 requires banks to establish comprehensive risk management systems } \\
\text { Royal Decree 216/ 2008; Article } 67 \text { addresses the need for banks to address interest } \\
\text { risk (IRR) in their risk management processes. CBE } 3 / 2008 \text {, standard } 105 \mathrm{~d} \text { also } \\
\text { addresses IRR. The BdE addresses and reviews a bank's IRR management when } \\
\text { preparing the annual risk matrix for the bank. } \\
\text { As part of onsite inspections the inspectors will review Board and committee minutes } \\
\text { to determine Board involvement in approval of risk management policies. The BdE } \\
\text { requires banks to consider volatility of the economic value, sensitivity of interest } \\
\text { margins, the impact of variable rate instruments on margins and economic value and } \\
\text { the estimates of IRR provided by internal models. }\end{array}$ \\
\hline EC2 & $\begin{array}{l}\text { The supervisor determines that banks have in place comprehensive and appropriate } \\
\text { IRR measurement systems and that any models and assumptions are validated on a } \\
\text { regular basis. It confirms that banks' limits reflect the risk strategy of the institution and } \\
\text { are understood by and regularly communicated to relevant staff. The supervisor also } \\
\text { confirms that exceptions to established policies, processes and limits should receive }\end{array}$ \\
\hline
\end{tabular}




\begin{tabular}{|c|c|}
\hline & the prompt attention of senior management, and the Board where necessary. \\
\hline $\begin{array}{l}\text { Description and } \\
\text { findings re EC2 }\end{array}$ & $\begin{array}{l}\text { Through onsite and offsite activities, the BdE reviews the bank's internal risk } \\
\text { measurement methodologies, management reports and the adequacy of risk limits } \\
\text { established. Departures from established policy are reviewed by inspectors. }\end{array}$ \\
\hline EC3 & $\begin{array}{l}\text { The supervisor requires that banks periodically perform appropriate stress tests to } \\
\text { measure their vulnerability to loss under adverse interest rate movements. }\end{array}$ \\
\hline $\begin{array}{l}\text { Description and } \\
\text { findings re EC3 }\end{array}$ & $\begin{array}{l}\text { CBE 3/2008, standard } 105 \text { 2c; banks must have written documentation concerning risk } \\
\text { management, stress test programs and limits for BdE review. BDE has adopted } \\
\text { guidelines for banks to follow for stress testing for IRR based on the CEBS guidelines. } \\
\text { The IRR must include a } 200 \text { bp stress shock. The banks must report semi-annually the } \\
\text { stress test results to the BdE. } \\
\text { The results of the stress tests are submitted to the BdE and are also included as part } \\
\text { of the ICAAP reports to support the determination of capital needs. The results are } \\
\text { analyzed by the BdE and discussed with the banks. }\end{array}$ \\
\hline \begin{tabular}{|l|l|l} 
Additional \\
criteria
\end{tabular} & \\
\hline AC1 & $\begin{array}{l}\text { The supervisor has the power to obtain from banks the results of their internal IRR } \\
\text { measurement systems, expressed in terms of the threat to economic value, including } \\
\text { using a standardized interest rate shock on the banking book. }\end{array}$ \\
\hline $\begin{array}{l}\text { Description and } \\
\text { findings re } A C 1\end{array}$ & $\begin{array}{l}\text { Banks file semiannually with the BdE reports on their internal stress test results. } \\
\text { Additionally, banks file the IAC reports which include all the internal IRR reports. }\end{array}$ \\
\hline AC2 & $\begin{array}{l}\text { The supervisor assesses whether the internal capital measurement systems of banks } \\
\text { adequately capture the IRR in the banking book. }\end{array}$ \\
\hline $\begin{array}{l}\text { Description and } \\
\text { findings re AC2 }\end{array}$ & The IAC reports include an assessment of IRR impact on capital. \\
\hline AC3 & $\begin{array}{l}\text { The supervisor requires stress tests to be based on reasonable worst case scenarios } \\
\text { and to capture all material sources of risk, including a breakdown of critical } \\
\text { assumptions. Senior management is required to consider these results when } \\
\text { establishing and reviewing a bank's policies, processes and limits for IRR. }\end{array}$ \\
\hline $\begin{array}{l}\text { Description and } \\
\text { findings re AC3 }\end{array}$ & $\begin{array}{l}\text { CBE 3/2008 standard } 1052 . c \text { and standard } 106.1 \text { set the requirements for stress } \\
\text { testing in accordance with BdE requirements. }\end{array}$ \\
\hline AC4 & $\begin{array}{l}\text { The supervisor requires banks to assign responsibility for IRR management to } \\
\text { individuals independent of and with reporting lines separate from those responsible for } \\
\text { trading and/or other risk-taking activities. In the absence of an independent risk } \\
\text { management function that covers IRR, the supervisor requires the bank to ensure that } \\
\text { there is a mechanism in place to mitigate a possible conflict of interest for managers } \\
\text { with both risk management and risk-taking responsibilities. }\end{array}$ \\
\hline $\begin{array}{l}\text { Description and } \\
\text { findings re AC4 }\end{array}$ & $\begin{array}{l}\text { The Board must approve and periodically review strategies and assumption policies, } \\
\text { management, control and reduction of risks the bank will be exposed to depending on } \\
\text { the economic cycle. Board must be informed periodically of the results and verify that } \\
\text { the functions required for IRR management have been performed. Banks are required } \\
\text { to have a specific risk management department and internal audit. } \\
\text { In the onsite and offsite reviews the BdE verifies the independence between risk } \\
\text { management and risk taking. }\end{array}$ \\
\hline $\begin{array}{l}\text { Assessment of } \\
\text { Principle } 16\end{array}$ & Compliant \\
\hline \multicolumn{2}{|l|}{ Comments } \\
\hline Principle 17. & Internal control and audit. Supervisors must be satisfied that banks have in place \\
\hline
\end{tabular}




\begin{tabular}{|c|c|}
\hline & $\begin{array}{l}\text { internal controls that are adequate for the size and complexity of their business. These } \\
\text { should include clear arrangements for delegating authority and responsibility; } \\
\text { separation of the functions that involve committing the bank, paying away its funds, } \\
\text { and accounting for its assets and liabilities; reconciliation of these processes; } \\
\text { safeguarding the bank's assets; and appropriate independent internal audit and } \\
\text { compliance functions to test adherence to these controls as well as applicable laws } \\
\text { and regulations. }\end{array}$ \\
\hline \multicolumn{2}{|l|}{$\begin{array}{l}\text { Essential } \\
\text { criteria }\end{array}$} \\
\hline EC1 & $\begin{array}{l}\text { Laws, regulations or the supervisor establish the responsibilities of the Board and } \\
\text { senior management with respect to corporate governance to ensure that there is } \\
\text { effective control over a bank's entire business. }\end{array}$ \\
\hline & $\begin{array}{l}\text { Royal Decree } 216.2008 \text { requires the Board or its designee to approve and periodically } \\
\text { review and approve the bank's risk management and internal control function. The } \\
\text { Decree requires banks to have transparent and well defined reporting lines and } \\
\text { organizational structure. The structure must contain an independent internal audit } \\
\text { function to monitor internal control and information systems. There must also be a } \\
\text { compliance function. These functions must operate independently of the risk taking } \\
\text { functions that it will monitor. } \\
\text { The internal audit and compliance functions must report periodically to the Board of } \\
\text { Directors on the results of their monitoring activities. } \\
\text { The guide for ICAAP requires banks to include in their reports submitted to the BdE: } \\
\text { The organizational structure and reporting lines for the internal audit function, including } \\
\text { the functions assigned and the resources allocated to periodical risk review by internal } \\
\text { audit. Also included is an assessment of the suitability of the internal audit function } \\
\text { and resources relative to the bank risk. Sections } 4.2 \text { and } 4.3 \text { of SABER provide } \\
\text { guidance to inspectors for assessing the adequacy of the internal audit and } \\
\text { incorporation into the risk matrix. }\end{array}$ \\
\hline EC2 & $\begin{array}{l}\text { The supervisor determines that banks have in place internal controls that are } \\
\text { adequate for the nature and scale of their business. These controls are the } \\
\text { responsibility of the Board and/or senior management and deal with organizational } \\
\text { structure, accounting policies and processes, checks and balances, and the } \\
\text { safeguarding of assets and investments. More specifically, these controls address: } \\
\text { - Organizational structure: definitions of duties and responsibilities, including clear } \\
\text { delegation of authority (for example, clear loan approval limits), decision-making } \\
\text { policies and processes, separation of critical functions (for example, business } \\
\text { origination, payments, reconciliation, risk management, accounting, audit and } \\
\text { compliance). } \\
\text { - Accounting policies and processes: reconciliation of accounts, control lists, } \\
\text { information for management. } \\
\text { - Checks and balances (or "four eyes principle"): segregation of duties, cross- } \\
\text { checking, dual control of assets, double signatures. } \\
\text { Safeguarding assets and investments: including physical control. }\end{array}$ \\
\hline $\begin{array}{l}\text { Description and } \\
\text { findings re EC2 }\end{array}$ & $\begin{array}{l}\text { Royal Decree } 1245 / 1995 \text { Requires banks (Board of Directors) to establish strong } \\
\text { corporate governance to ensure the safety and soundness of the bank. Establish } \\
\text { strong internal control procedures and organizational units to avoid the bank becoming }\end{array}$ \\
\hline
\end{tabular}




\begin{tabular}{|c|c|}
\hline & $\begin{array}{l}\text { a victim of money laundering schemes. } \\
\text { The requirements are further developed in Royal Decree } 216 / 2008 \text {. The Decree } \\
\text { requires that the Board receive periodic reports from the internal audit and compliance } \\
\text { functions. The Board is also required to review the policies and systems to ensure that } \\
\text { they remain adequate on scope and in relation to the bank's risk profile. The Decree } \\
\text { also requires the BdE to monitor compliance during the onsite inspections and review } \\
\text { of bank filed reports. } \\
\text { The BdE assesses in its supervision (SABER): (1) The suitability of the composition, } \\
\text { functions and responsibility invested in and delegated by the Board. (2) Whether the } \\
\text { complexity of risk management is suitable for the bank. (3) Capital plans are suited to } \\
\text { the risk profile and the economic environment. (4) The way in which the Board takes } \\
\text { responsibility for regulatory compliance and implements corrective action required by } \\
\text { the BdE. }\end{array}$ \\
\hline EC3 & $\begin{array}{l}\text { Laws, regulations or the supervisor place the responsibility for the control environment } \\
\text { on the Board and senior management of the bank. The supervisor requires that the } \\
\text { Board and senior management understand the underlying risks in their business and } \\
\text { are committed to a strong control environment. }\end{array}$ \\
\hline & $\begin{array}{l}\text { Circular } 3 / 2008 \text {, rule } 105 \text { requires the establishment of corporate governance rules. It } \\
\text { also requires that the rules be approved and the organizational structure to monitor } \\
\text { compliance be approved by the Board of Directors. The Board must approve the } \\
\text { internal control policies and must require regular reporting from the internal control } \\
\text { functions and auditing. } \\
\text { The Circular also requires the establishment of risk management policies for the } \\
\text { various banking risks, such as, credit, interest, concentration. }\end{array}$ \\
\hline EC4 & $\begin{array}{l}\text { The supervisor has the power to require changes in the composition of the Board and } \\
\text { senior management to address any prudential concerns related to the satisfaction of } \\
\text { these criteria. }\end{array}$ \\
\hline $\begin{array}{l}\text { Description and } \\
\text { findings re EC4 }\end{array}$ & $\begin{array}{l}\text { Under Law } 26 / 1988 \text {, Article } 31 \text {, the BdE has the authority to intervene an institution or } \\
\text { remove directors or management to address unsafe and unsound banking practices. } \\
\text { The Article provides the power to intervene or remove the Board when deficiencies in } \\
\text { corporate governance and controls are grave and threaten the solvency of the bank or } \\
\text { make the financial statements unreliable to determine the condition of the bank. }\end{array}$ \\
\hline EC5 & $\begin{array}{l}\text { The supervisor determines that there is an appropriate balance in the skills and } \\
\text { resources of the back office and control functions relative to the front office/business } \\
\text { origination. }\end{array}$ \\
\hline $\begin{array}{l}\text { Description and } \\
\text { findings re EC5 }\end{array}$ & $\begin{array}{l}\text { The BdE reviews the hierarchy established for the management of each risk and the } \\
\text { delegation of functions and responsibilities. The extent of centralization and } \\
\text { delegations and the separation of duties between the various risk units. } \\
\text { The ICAAP guide requires the bank to report the Organization of the risk function and } \\
\text { of powers, responsibilities and delegations, Risk control function. Reports on the risk } \\
\text { function. } \\
\text { The hierarchy established in the institution for the management of each risk (in its } \\
\text { three facets: assumption, measurement and control) and the delegation of functions } \\
\text { and responsibilities should be described. The levels of management centralization- } \\
\text { decentralization, the boundaries of responsibility and authorization, and the separation }\end{array}$ \\
\hline
\end{tabular}




\begin{tabular}{|c|c|}
\hline & $\begin{array}{l}\text { of the functions of the various risk management bodies should be explained. } \\
\text { If, for some risk there exists a separate or independent risk function, the structure and } \\
\text { responsibilities of the attendant control function should be indicated. } \\
\text { In discussions with banks it was determined that during inspections of trading desks, } \\
\text { the BdE reviews back room operations. }\end{array}$ \\
\hline EC6 & $\begin{array}{l}\text { The supervisor determines that banks have a permanent compliance function that } \\
\text { assists senior management in managing effectively the compliance risks faced by the } \\
\text { bank. The compliance function must be independent of the business activities of the } \\
\text { bank. The supervisor determines that the Board exercises oversight of the } \\
\text { management of the compliance function. }\end{array}$ \\
\hline $\begin{array}{l}\text { Description and } \\
\text { findings re EC6 }\end{array}$ & $\begin{array}{l}\text { Royal Decree } 216 / 2008 \text {, Article } 66 \text { establishes the requirements for corporate } \\
\text { governance and risk management, including a compliance function. During onsite } \\
\text { inspections the BdE reviews the compliance function and incorporates the results of its } \\
\text { review in the bank's risk matrix. The compliance function is also addressed in the } \\
\text { ICAAP report filed by the bank with the BdE. }\end{array}$ \\
\hline EC7 & $\begin{array}{l}\text { The supervisor determines that banks have an independent, permanent and effective } \\
\text { internal audit function charged with (i) ensuring that policies and processes are } \\
\text { complied with and (ii) reviewing whether the existing policies, processes and controls } \\
\text { remain sufficient and appropriate for the bank's business. }\end{array}$ \\
\hline & $\begin{array}{l}\text { The BdE reviews the annual internal audit action plan for each risk. To ensure that } \\
\text { audit addresses the risk policies, the management, limiting and monitoring of risk } \\
\text { limits, and the review of impaired assets. } \\
\text { For each of the institution's significant risks, the BdE evaluates the adequacy and } \\
\text { degree of compliance of the following: } \\
\text { - Risk policy: limits, diversification and mitigation. } \\
\text { - Organization of the risk function: powers, segregation of functions, } \\
\text { responsibilities and delegation; risk control function; reports on the risk function. } \\
\text { - Management tools: measurement systems and methodologies, acceptance, } \\
\text { communication, control and monitoring; procedural manuals; quality and } \\
\text { sufficiency of IT systems; quality and sufficiency of information. } \\
\text { - The policy and tools for impaired asset monitoring and recovery (where } \\
\text { appropriate). } \\
\text { - The annual internal audit action plan for each risk. }\end{array}$ \\
\hline EC8 & $\begin{array}{l}\text { The supervisor determines that the internal audit function: } \\
\text { - has sufficient resources, and staff that are suitably trained and have relevant } \\
\text { experience to understand and evaluate the business they are auditing; } \\
\text { - has appropriate independence, including reporting lines to the Board and status } \\
\text { within the bank to ensure that senior management reacts to and acts upon its } \\
\text { recommendations; } \\
\text { - has full access to and communication with any member of staff as well as full } \\
\text { access to records, files or data of the bank and its affiliates, whenever relevant to }\end{array}$ \\
\hline
\end{tabular}




\begin{tabular}{|c|c|}
\hline & $\begin{array}{l}\text { the performance of its duties; } \\
\text { - employs a methodology that identifies the material risks run by the bank; } \\
\text { - prepares an audit plan based on its own risk assessment and allocates its } \\
\text { resources accordingly; and } \\
\text { - has the authority to assess any outsourced functions. }\end{array}$ \\
\hline $\begin{array}{l}\text { Description and } \\
\text { findings re EC8 }\end{array}$ & $\begin{array}{l}\text { The bank provides the BdE a description of its audit function and its assessment of the } \\
\text { adequacy of the function given the risks of the bank. The BdE reviews the audit plans } \\
\text { and the management of risks. During the supervision process, the BdE has ongoing } \\
\text { discussions with the banks' internal audit and reviews work papers as needed. }\end{array}$ \\
\hline \multicolumn{2}{|l|}{$\begin{array}{l}\text { Additional } \\
\text { criteria }\end{array}$} \\
\hline AC1 & $\begin{array}{l}\text { In those countries with a unicameral Board structure (as opposed to a bicameral } \\
\text { structure with a Supervisory Board and a Management Board), the supervisor requires } \\
\text { the Board to include a number of experienced non-executive directors. }\end{array}$ \\
\hline $\begin{array}{l}\text { Description and } \\
\text { findings re AC1 }\end{array}$ & $\begin{array}{l}\text { Royal Decree } 1245 / 1995 \text { and the Code of Corporate Governance published by the } \\
\text { securities regulator for listed companies require that the majority of directors be } \\
\text { independent and external and possessing the right qualifications. }\end{array}$ \\
\hline AC2 & $\begin{array}{l}\text { The supervisor requires the internal audit function to report to an audit committee, or } \\
\text { an equivalent structure. }\end{array}$ \\
\hline $\begin{array}{l}\text { Description and } \\
\text { findings re AC2 }\end{array}$ & Market regulations and BdE guidance require that audit functions be independent. \\
\hline AC3 & $\begin{array}{l}\text { In those countries with a unicameral Board structure, the supervisor requires the audit } \\
\text { committee to include experienced non-executive directors. }\end{array}$ \\
\hline $\begin{array}{l}\text { Description and } \\
\text { findings re AC3 }\end{array}$ & $\begin{array}{l}\text { For listed banks, which banks are, the audit committee must be composed of a } \\
\text { majority of directors that are not bank executives and presided by a non-executive } \\
\text { director. }\end{array}$ \\
\hline AC4 & $\begin{array}{l}\text { Laws or regulations provide, or the supervisor ensures, that banks must notify the } \\
\text { supervisor as soon as they become aware of any material information which may } \\
\text { negatively affect the fitness and propriety of a Board member or a member of the } \\
\text { senior management. }\end{array}$ \\
\hline $\begin{array}{l}\text { Description and } \\
\text { findings re AC4 }\end{array}$ & $\begin{array}{l}\text { Directors are personally liable for the losses to the institution as a result of their } \\
\text { actions. This encourages directors to report to BdE any concerns over the actions of a } \\
\text { Board member. }\end{array}$ \\
\hline $\begin{array}{l}\text { Assessment of } \\
\text { Principle } 17\end{array}$ & Compliant \\
\hline \multicolumn{2}{|l|}{ Comments } \\
\hline Principle 18. & $\begin{array}{l}\text { Abuse of financial services. Supervisors must be satisfied that banks have adequate } \\
\text { policies and processes in place, including strict "know-your-customer" rules, that } \\
\text { promote high ethical and professional standards in the financial sector and prevent the } \\
\text { bank from being used, intentionally or unintentionally, for criminal activities. }\end{array}$ \\
\hline \multicolumn{2}{|l|}{$\begin{array}{l}\text { Essential } \\
\text { criteria }\end{array}$} \\
\hline EC1 & $\begin{array}{l}\text { Laws or regulations clarify the duties, responsibilities and powers of the banking } \\
\text { supervisor and other competent authorities, if any, related to the supervision of banks' } \\
\text { internal controls and enforcement of the relevant laws and regulations regarding } \\
\text { criminal activities. }\end{array}$ \\
\hline Description and & Law 10/2010 establishes that AML/CFT compliance supervision is a specific \\
\hline
\end{tabular}




\begin{tabular}{|c|c|}
\hline findings re EC1 & 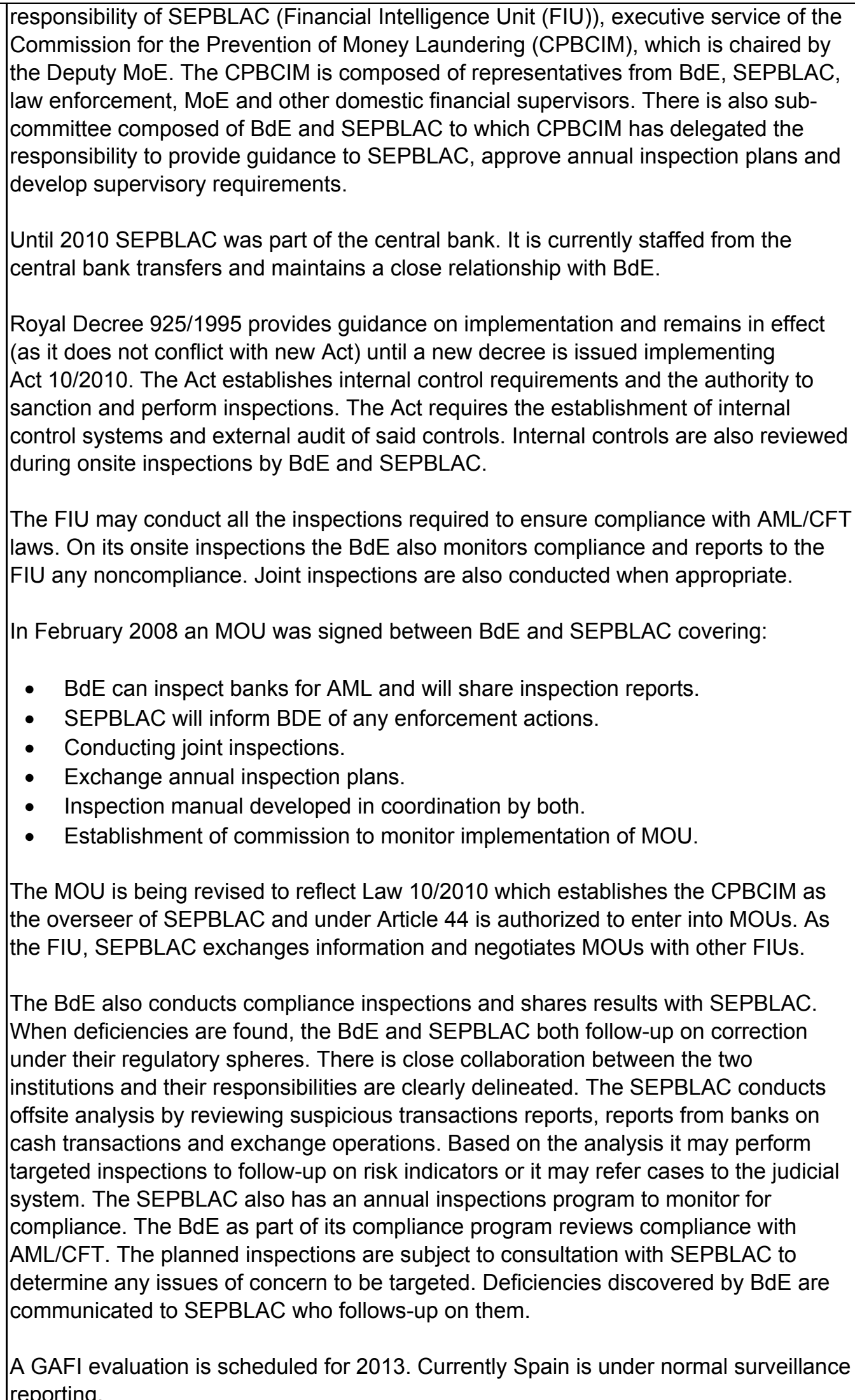 \\
\hline
\end{tabular}




\begin{tabular}{|c|c|}
\hline EC2 & $\begin{array}{l}\text { The supervisor must be satisfied that banks have in place adequate policies and } \\
\text { processes that promote high ethical and professional standards and prevent the bank } \\
\text { from being used, intentionally or unintentionally, for criminal activities. This includes } \\
\text { the prevention and detection of criminal activity, and reporting of such suspected } \\
\text { activities to the appropriate authorities. }\end{array}$ \\
\hline & $\begin{array}{l}\text { Law10/2010 requires banks to establish due diligence and internal control procedures } \\
\text { for AML and illicit activities purposes. The BdE in its compliance inspections analyses } \\
\text { the overall compliance function, assessing periodically internal procedures and } \\
\text { controls, under a risk-based approach. The examination of AML/CFT issues is one of } \\
\text { the key topics among those tasks. } \\
\text { Law 10/2010 implements EU Directives on AML/CFT. } \\
\text { - Requires banks to set-up customer due diligence procedures. } \\
\text { - Establishes the requirement for reporting suspicious transactions and provides } \\
\text { guidelines for identifying said transactions. } \\
\text { Establishes requirements for internal control and risk management over anti } \\
\text { money laundering. These include the naming of a dedicated compliance officer, } \\
\text { internal control system must be reviewed annually by an external expert, the } \\
\text { expert must be approved by SEPBLAC, and training programs for staff must be } \\
\text { established. } \\
\text { AML/CFT is incorporated in the risk matrix used by the BdE to review and rate risk } \\
\text { management and corporate at banks. Offsite monitoring is also conducted by the } \\
\text { review of the external reports required by ACT } 10 / 2010 \text { and following-up on correction } \\
\text { of deficiencies. Although SEPBLAC was moved from BdE, the activities of BdE to } \\
\text { monitor compliance with AML laws continue and there is close collaboration with } \\
\text { SEPBLAC. } \\
\text { Law } 5 / 2009 \text { requires the BdE when reviewing proposed controlling ownership control } \\
\text { in a bank to review the shareholders' financial solvency, legal background, ensure that } \\
\text { the change in control will not affect the bank's AML capacity. Fit and proper criteria are } \\
\text { also applied during the licensing process and reviewed during the onsite inspection } \\
\text { process by the BdE (See CP5). } \\
\text { Law } 10 / 2010 \text { requires the filing of suspicious activity reports with the secretary general } \\
\text { of CPBCIM. Article } 30 \text { requires that banks establish written policies and procedures to } \\
\text { ensure hiring practices and training promote high ethical standards. }\end{array}$ \\
\hline EC3 & $\begin{array}{l}\text { In addition to reporting to the FIU or other designated authorities, banks report to the } \\
\text { banking supervisor suspicious activities and incidents of fraud when they are material } \\
\text { to the safety, soundness or reputation of the bank. }\end{array}$ \\
\hline $\begin{array}{l}\text { Description and } \\
\text { findings re EC3 }\end{array}$ & $\begin{array}{l}\text { Law 10/2010, Article } 18 \text { requires banks to report suspicious activities to the SEPBLAC. } \\
\text { The permanent contact and exchange of information between the SEPBLAC and the } \\
\text { BdE ensures that the information is promptly shared. Additionally, the BdE is a } \\
\text { member of the Commission for the Prevention of Money Laundering which enables it } \\
\text { to stay abreast of trends. During its inspections, the BdE has access to suspicious } \\
\text { activity reports and, in addition, SEPBLAC informs BdE of significant reports. } \\
\text { Concerning fraud, the banks file directly with the BdE, additionally the BdE requests }\end{array}$ \\
\hline
\end{tabular}




\begin{tabular}{|c|c|}
\hline & \\
\hline EC4 & $\begin{array}{l}\text { The supervisor is satisfied that banks establish "know-your-customer" (KYC) policies } \\
\text { and processes which are well documented and communicated to all relevant staff. } \\
\text { Such policies and processes must also be integrated into the bank's overall risk } \\
\text { management. The KYC management program, on a group-wide basis, has as its } \\
\text { essential elements: } \\
\text { - a customer acceptance policy that identifies business relationships that the bank } \\
\text { will not accept; } \\
\text { - a customer identification, verification and due diligence program; this } \\
\text { encompasses verification of beneficial ownership and includes risk-based } \\
\text { reviews to ensure that records are updated and relevant; } \\
\text { - policies and processes to monitor and recognise unusual or potentially } \\
\text { suspicious transactions, particularly of high-risk accounts; } \\
\text { - escalation to the senior management level of decisions on entering into business } \\
\text { relationships with high-risk accounts, such as those for politically exposed } \\
\text { persons, or maintaining such relationships when an existing relationship } \\
\text { becomes high-risk; and } \\
\text { clear rules on what records must be kept on consumer identification and } \\
\text { individual transactions and their retention period. Such records should have at } \\
\text { least a five year retention period. }\end{array}$ \\
\hline & $\begin{array}{l}\text { Act 10/2010 sets the KYC requirements including rules on ultimate beneficial owner, } \\
\text { establishing the nature of the business, updating of information, refrain from doing } \\
\text { business if KYC information cannot be obtained, sets requirements for due diligence } \\
\text { standards, requires banks to have written procedures for KYC, requires senior } \\
\text { management approval to deal with PEPs and sets ten years as a recordkeeping } \\
\text { minimum. In coordination with SEPBLAC, the BdE has issued inspection procedures } \\
\text { for its inspectors to cover AML/CFT policy reviews, recordkeeping, reporting, training } \\
\text { and communication of suspicious transactions. } \\
\text { Specifically, Chapter II lays down KYC extensive requirements : } \\
\text { Article3: previously to entering into business. } \\
\text { Article4: Ultimate beneficial owner. } \\
\text { Article } 5: \text { nature and circumstances of business. } \\
\text { Article } 6: \text { permanent updating. } \\
\text { Article } 7: \text { refrain from doing business if appropriate KYC cannot be conducted. } \\
\text { Article } 26.1 \text { requires written approval of procedures and policies about due diligence, } \\
\text { information, documents keeping, internal controls, risks valuation and management, } \\
\text { regulation compliance, specific customer acceptance policy, etc. } \\
\text { Article } 26.3 \text { requires that banks have written procedures (handbook), duly updated. } \\
\text { Article } 31 \text { extends AML/CTF requirements to branches and subsidiaries set in third } \\
\text { countries. } \\
\text { Article } 14.2 \text { requires senior management approval to enter into business with PEPs. } \\
\text { Article } 25 \text { requires that documents must be kept for ten years minimum. } \\
\text { Article } 17 \text { and Article } 34 \text { of EU Directive } 2005 / 60 / C E \text { (Directive)require that the bank } \\
\text { provide training to staff, directors and agents on the identification of high risk accounts } \\
\text { and suspicious transactions. Due diligence requirements for KYC are to be }\end{array}$ \\
\hline
\end{tabular}




\begin{tabular}{|c|c|}
\hline & $\begin{array}{l}\text { communicated to all relevant staff and training provided. } \\
\text { Articles } 6,7 \text {, and } 25 \text { establish the record retention and updating requirements. } \\
\text { Compliance is reviewed during the annual compliance reviews performed by external } \\
\text { audit and as part of the internal control procedures. } \\
\text { Article } 7 \text { and Article } 13 \text { of the Directive establish the monitoring of high risk accounts } \\
\text { and the additional requirements including reporting to the Board. }\end{array}$ \\
\hline EC5 & $\begin{array}{l}\text { The supervisor is satisfied that banks have enhanced due diligence policies and } \\
\text { processes regarding correspondent banking. Such policies and processes } \\
\text { encompass: } \\
\text { - gathering sufficient information about their respondent banks to understand fully } \\
\text { the nature of their business and customer base, and how they are supervised; } \\
\text { and } \\
\text { not establishing or continuing correspondent relationships with foreign banks that } \\
\text { do not have adequate controls against criminal activities or that are not } \\
\text { effectively supervised by the relevant authorities, or with those banks that are } \\
\text { considered to be shell banks. }\end{array}$ \\
\hline & $\begin{array}{l}\text { Act 10/2010, Article } 13 \text { establishes requirements for correspondent banking. These } \\
\text { include: banks must gather sufficient information on correspondents to understand the } \\
\text { KYC procedures and the home supervision AML standards, document respective } \\
\text { responsibilities on KYC and not enter into relationships with shell banks. Relationships } \\
\text { cannot be established if the due diligence cannot be accomplished or deficiencies are } \\
\text { found. } \\
\text { Article } 13 \text { of the Directive also establishes requirements for opening and maintaining } \\
\text { correspondent accounts. } \\
\text { During reviews by the BdE and the external expert's annual assessment, compliance } \\
\text { with this requirement is verified. }\end{array}$ \\
\hline EC6 & $\begin{array}{l}\text { The supervisor periodically confirms that banks have sufficient controls and systems in } \\
\text { place for preventing, identifying and reporting potential abuses of financial services, } \\
\text { including money laundering. }\end{array}$ \\
\hline $\begin{array}{l}\text { Description and } \\
\text { findings re EC6 }\end{array}$ & $\begin{array}{l}\text { During its onsite inspections the BdE inspectors and the SEPBLAC cover this area. } \\
\text { The BdE also reviews the reports generated by internal audit. Article } 28 \text { of Law } \\
10 / 2010 \text { requires the banks to have an external expert conduct a review of its internal } \\
\text { control process and judge its efficacy in ensuring compliance with legal requirements. } \\
\text { The banks must inform SEPBLAC of who the expert will be for their review. In } \\
\text { practice, banks contract external auditors for this review and the reports are provided } \\
\text { to the BdE and SEPBLAC. }\end{array}$ \\
\hline EC7 & $\begin{array}{l}\text { The supervisor has adequate enforcement powers (regulatory and/or criminal } \\
\text { prosecution) to take action against a bank that does not comply with its obligations } \\
\text { related to criminal activities. }\end{array}$ \\
\hline $\begin{array}{l}\text { Description and } \\
\text { findings re EC7 }\end{array}$ & $\begin{array}{l}\text { Law } 10 / 2010 \text {, Chapter VIII describes the sanctioning process. The sanctioning regime } \\
\text { in Spain classifies violations as very grave, grave and minor. Articles } 51-53 \text {, } \\
\text { categorize infractions of the Law into the various gravity categories. Very grave } \\
\text { violations must be approved by the Council of Ministers, while grave violations are } \\
\text { approved by the MoE. Minor violations are approved by General Director of the } \\
\text { Treasury. Very grave violations may be subject to fines up to } 1.5 \text { million Euros of }\end{array}$ \\
\hline
\end{tabular}




\begin{tabular}{|c|c|}
\hline & $\begin{array}{l}5 \text { percent of bank capital whichever is greater. Fines can also be applied to directors, } \\
\text { officers and staff implicated. Fines for grave violations are up to the maximum of one } \\
\text { percent of capital or } 150,000 \text { Euros. } \\
\text { The assessors were provided with a list of sanctions imposed since 2007. A total of } \\
24 \text { sanctions have been imposed, ranging from } 90,000 \text { to } 2,350,000 \text { euros. Sanctions } \\
\text { are imposed by the Justice Department. }\end{array}$ \\
\hline EC8 & 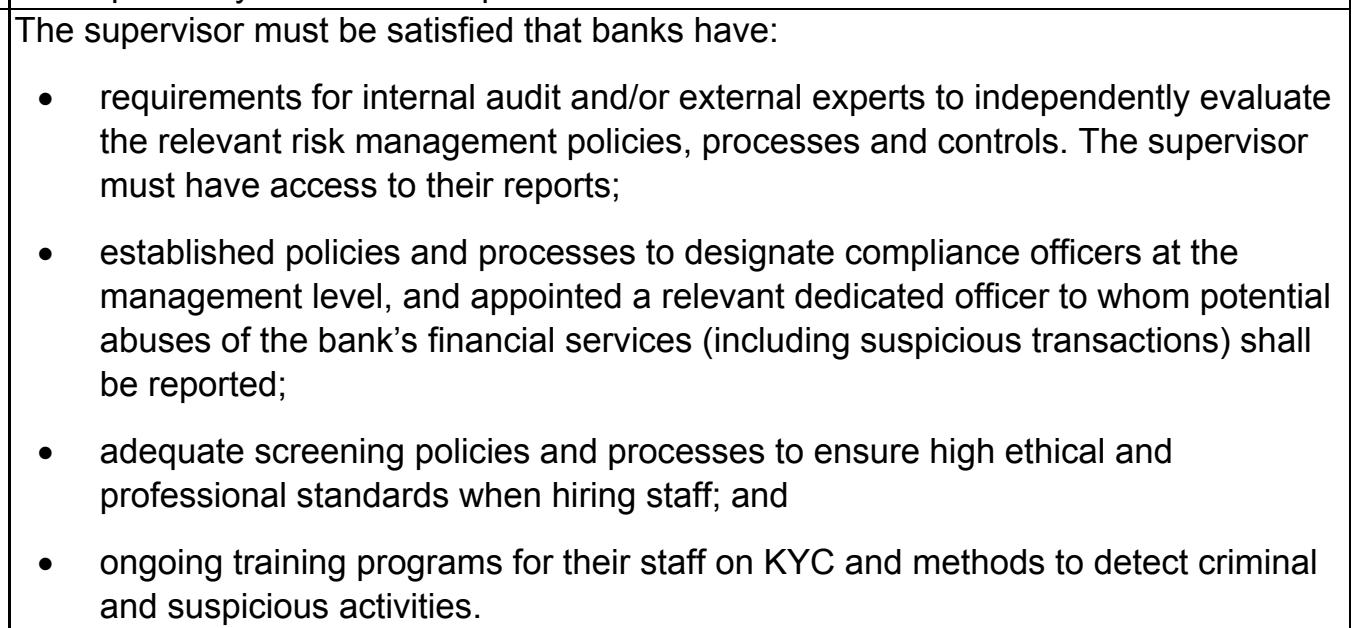 \\
\hline $\begin{array}{l}\text { Description and } \\
\text { findings re EC8 }\end{array}$ & $\begin{array}{l}\text { Article } 28 \text { of Act } 10 / 2010 \text { requires that procedures and internal controls must be } \\
\text { reviewed annually by an external expert. The external expert (external audit firm) } \\
\text { performs a detailed review of compliance with AML requirements and submits copies } \\
\text { of the report to the BdE and SEPBLAC. } \\
\text { Article } 26 \text { requires the designation of an AML officer that should oversee compliance } \\
\text { and be on the Board, a specific internal control unit to monitor compliance must also } \\
\text { be established. The internal control unit must function independently of the internal } \\
\text { audit to provide an additional review process. An internal manual must be developed } \\
\text { and it is recommended that it be submitted to SEPBLAC for review. Independently, the } \\
\text { manuals are reviewed during onsite inspections by SEPBLAC and BdE. Article } 29 \\
\text { requires the establishment of training programs for compliance with AML issues and } \\
\text { monitoring and with the requirements of the law; develop a guide for the prevention of } \\
\text { AML. Article } 30 \text { establishes requirements for hiring staff to ensure high ethical } \\
\text { standards. }\end{array}$ \\
\hline EC9 & $\begin{array}{l}\text { The supervisor determines that banks have clear policies and processes for staff to } \\
\text { report any problems related to the abuse of the banks' financial services to either local } \\
\text { management or the relevant dedicated officer or to both. The supervisor also confirms } \\
\text { that banks have adequate management information systems to provide managers and } \\
\text { the dedicated officers with timely information on such activities. }\end{array}$ \\
\hline $\begin{array}{l}\text { Description and } \\
\text { findings re EC9 }\end{array}$ & $\begin{array}{l}\text { Article } 29 \text { of Act } 10 / 2010 \text { states that training programs for staff cover the way they } \\
\text { should act and what should be reported. Article } 18.4 \text { establishes that bank employees } \\
\text { can report directly to the FIU when the bank does not. Article } 23 \text { SEPBLAC and BdE } \\
\text { review compliance during onsite reviews and also rely on external expert reports. }\end{array}$ \\
\hline EC10 & $\begin{array}{l}\text { Laws and regulations ensure that a member of a bank's staff who reports suspicious } \\
\text { activity in good faith either internally or directly to the relevant authority cannot be held } \\
\text { liable. }\end{array}$ \\
\hline $\begin{array}{l}\text { Description and } \\
\text { findings re EC10 }\end{array}$ & $\begin{array}{l}\text { Article } 30 \text { protects the confidentiality of bank staff that reports suspicious activity. } \\
\text { Article } 23 \text { states that staff will not assume any liability for reporting to the authorities on }\end{array}$ \\
\hline
\end{tabular}




\begin{tabular}{|c|c|}
\hline & $\begin{array}{l}\text { suspected AML issues. It is the AML officer that will appear at judicial procedures. } \\
\text { Article } 46 \text { establishes that the identity of the reporter to the SEPBLAC shall be kept } \\
\text { confidential. }\end{array}$ \\
\hline EC11 & $\begin{array}{l}\text { The supervisor is able to inform the FIU and, if applicable, other designated authority } \\
\text { of any suspicious transactions. In addition, it is able, directly or indirectly, to share with } \\
\text { relevant judicial authorities information related to suspected or actual criminal } \\
\text { activities. }\end{array}$ \\
\hline $\begin{array}{l}\text { Description and } \\
\text { findings re EC11 }\end{array}$ & $\begin{array}{l}\text { Article } 48 . \text { Requires the BdE to report to the CPBCIM for the prevention of money } \\
\text { laundering any violations of Act } 10 / 2010 \text {. The BdE is a member of CPBCIM and } \\
\text { information is exchanged at the meetings and regularly between the supervisory staff } \\
\text { of SEPBLAC and BdE. Article } 6 \text { enables BdE to share information with judicial } \\
\text { authorities. BdE shares all information with SEPBLAC. }\end{array}$ \\
\hline EC12 & $\begin{array}{l}\text { The supervisor is able, directly or indirectly, to cooperate with the relevant domestic } \\
\text { and foreign financial sector supervisory authorities or share with them information } \\
\text { related to suspected or actual criminal activities where this information is for } \\
\text { supervisory purposes. }\end{array}$ \\
\hline $\begin{array}{l}\text { Description and } \\
\text { findings re EC12 }\end{array}$ & $\begin{array}{l}\text { Royal Decree 1298/1986, Article } 6 \text { enables the BdE to share information with foreign } \\
\text { supervisors on illegitimate activity. Most information exchanges occur at the FIU level. } \\
\text { Article } 48 \text { of Law 10/2010 empowers SEPBLAC to exchange information with other } \\
\text { FIUs. } \\
\text { All relevant domestic authorities sit on the CPBCIM where sanctions are discussed, } \\
\text { examination plans of SEPBLAC are discussed and relevant information exchanged } \\
\text { between the agencies, including Justice and law enforcement that are also } \\
\text { represented. }\end{array}$ \\
\hline \multicolumn{2}{|l|}{$\begin{array}{l}\text { Additional } \\
\text { criteria }\end{array}$} \\
\hline AC1 & $\begin{array}{l}\text { If not done by another authority, the supervisor has in-house resources with specialist } \\
\text { expertise for addressing criminal activities. }\end{array}$ \\
\hline $\begin{array}{l}\text { Description and } \\
\text { findings re AC1 }\end{array}$ & Criminal activities are addressed by the SEPBLAC. \\
\hline $\begin{array}{l}\text { Assessment of } \\
\text { Principle } 18\end{array}$ & Compliant \\
\hline \multicolumn{2}{|l|}{ Comments } \\
\hline Principle 19. & $\begin{array}{l}\text { Supervisory approach. An effective banking supervisory system requires that } \\
\text { supervisors develop and maintain a thorough understanding of the operations of } \\
\text { individual banks and banking groups, and also of the banking system as a whole, } \\
\text { focusing on safety and soundness, and the stability of the banking system. }\end{array}$ \\
\hline \multicolumn{2}{|l|}{$\begin{array}{l}\text { Essential } \\
\text { criteria }\end{array}$} \\
\hline EC1 & $\begin{array}{l}\text { The supervisor has policies and processes in place to develop and maintain a } \\
\text { thorough understanding of the risk profile of individual banks and banking groups. }\end{array}$ \\
\hline $\begin{array}{l}\text { Description and } \\
\text { findings re EC1 }\end{array}$ & $\begin{array}{l}\text { The Bank of Spain Supervisory Model (SABER) published in } 2009 \text { establishes the } \\
\text { general framework for the BdE supervisory process. The focus is to ensure that banks } \\
\text { are well capitalized, comply with current regulations and are prudent in the } \\
\text { management and control of their risks. The approach is based on a mix of onsite and } \\
\text { offsite reviews, the filing of regulatory reports by the banks and collaboration with other } \\
\text { domestic and foreign supervisors. } \\
\text { In implementing its supervisory approach the BdE uses a risk-based approach that is }\end{array}$ \\
\hline
\end{tabular}




\begin{tabular}{|c|c|}
\hline & $\begin{array}{l}\text { based on building the risk profile of the banks by the use of a risk matrix. The risk } \\
\text { matrix encompasses the major banking risks and the BdE assigns a risk rating to } \\
\text { prioritize the supervisory focus. } \\
\text { The main components of the supervisory model are: (1) Permanent onsite presence at } \\
16 \text { banks representing the largest and/or riskier. Onsite and offsite activities are mixed } \\
\text { and offsite analysts participate in the inspections. (2) Increased use of the IAC report } \\
\text { as a risk measuring tool. }\end{array}$ \\
\hline EC2 & $\begin{array}{l}\text { The supervisor monitors and assesses trends, developments and risks for the banking } \\
\text { system as a whole. The supervisor also takes into account developments in non-bank } \\
\text { financial institutions through frequent contact with their regulators. }\end{array}$ \\
\hline $\begin{array}{l}\text { Description and } \\
\text { findings re EC2 }\end{array}$ & $\begin{array}{l}\text { The Financial Stability Division assesses trends, developments and risks for the } \\
\text { banking system as a whole. The Offsite Analysis Division produces, maintains and } \\
\text { makes available, accounting data and various indicators in support of the Directorate } \\
\text { for General Banking Supervision that is responsible for individual bank supervision. } \\
\text { The BdE coordinates and shares information with the other financial regulators. } \\
\text { There is information exchange with other regulators to share issues of concern. }\end{array}$ \\
\hline EC3 & $\begin{array}{l}\text { The supervisor uses a methodology for determining and assessing on an ongoing } \\
\text { basis the nature, importance and scope of the risks to which individual banks or } \\
\text { banking groups are exposed. The methodology should cover, inter alia, the business } \\
\text { focus, the risk profile and the internal control environment, and should permit relevant } \\
\text { comparisons between banks. Supervisory work is prioritized based on the results of } \\
\text { these assessments. }\end{array}$ \\
\hline & $\begin{array}{l}\text { To establish the supervisory risk profile of each institution, the BdE has developed a } \\
\text { risk-based supervisory approach known by its Spanish acronym, SABER. Based on } \\
\text { the work done under SABER, a risk matrix is completed for each bank based on the } \\
\text { information produced by supervisory activities and a numerical risk rating score (1-4) } \\
\text { assigned. The risk matrix scores provide for a structured and uniform supervisory risk } \\
\text { profile which is updated and revised on an ongoing basis to reflect the results of } \\
\text { supervisory activities. } \\
\text { The risk matrix summarizes all the information acquired as a consequence of the } \\
\text { accounting review, the economic and financial analysis, and the review of regulatory } \\
\text { compliance, the evaluation of risks and solvency and serves as the basis for } \\
\text { determining the bank's risk profile. Based on the risk score, the BdE focuses its } \\
\text { supervision. } \\
\text { With the legal revisions in } 2007 \text { and } 2008 \text { the ability of the BdE to require bank } \\
\text { implementation of risk management systems and corporate governance was } \\
\text { enhanced. Guidelines have been developed for banks and inspectors and banks } \\
\text { through ICAAP process and the instructions for the preparation of their IAC reports } \\
\text { inform. }\end{array}$ \\
\hline EC4 & $\begin{array}{l}\text { The supervisor confirms banks' and banking groups' compliance with prudential } \\
\text { regulations and other legal requirements. }\end{array}$ \\
\hline $\begin{array}{l}\text { Description and } \\
\text { findings re EC4 }\end{array}$ & $\begin{array}{l}\text { As detailed in Sections } 3.3 \text { and } 3.4 \text { of the supervisory model, the BdE through its } \\
\text { supervisory activities monitors compliance with regulations. The BdE conducts } \\
\text { compliance inspections and in its solvency reviews it also reviews compliance. }\end{array}$ \\
\hline EC5 & $\begin{array}{l}\text { The supervisor requires banks to notify it of any substantive changes in their activities, } \\
\text { structure and overall condition, or as soon as they become aware of any material }\end{array}$ \\
\hline
\end{tabular}




\begin{tabular}{|c|c|}
\hline & adverse developments, including breach of legal or prudential requirements. \\
\hline $\begin{array}{l}\text { Description and } \\
\text { findings re EC5 }\end{array}$ & $\begin{array}{l}\text { Law } 26 / / 1988 \text {, Article } 61.1 \text { requires banks to promptly notify the BdE of substantive } \\
\text { changes to its capital structure. } \\
\text { Changes in the articles of association must be communicated to the BdE within } \\
15 \text { days of their adoption, unless subject to prior approval by the MoF. Article } 8 \text { RDL } \\
1245 / 1995 . \\
\text { The opening of branches abroad and the purchase of significant participations in } \\
\text { Spanish or foreign institutions are subject to previous authorization by the BdE. } \\
\text { Chapter II RDL } 1245 / 1995 \text {. } \\
\text { Banks must communicate to the BDE any deficit of eligible own funds to applicable } \\
\text { regulations. Article } 75, \text { Royal Decree } 216 / 2008 \text {. } \\
\text { These requirements are reinforced by the intrusive supervisory approach that involves } \\
\text { frequent communication with the bank and permanent onsite inspection staff at the } \\
\text { large banks. }\end{array}$ \\
\hline EC6 & $\begin{array}{l}\text { The supervisor has an adequate information system which facilitates the processing, } \\
\text { monitoring and analysis of prudential information. The system aids the identification of } \\
\text { areas requiring follow-up action. }\end{array}$ \\
\hline $\begin{array}{l}\text { Description and } \\
\text { findings re EC6 }\end{array}$ & $\begin{array}{l}\text { The BdE has a number of information technology tools to support its supervisory } \\
\text { process. The primary tool is the Data Analysis System (SAD). SAD facilitates analysis } \\
\text { of the information filed by the banks, both at the individual level and consolidated. It } \\
\text { also enables peer group comparisons. } \\
\text { The Central Credit Registry provides access to individual borrowers and economic } \\
\text { groups. The records can also be grouped by sectors or regions. And includes related } \\
\text { party loans, loan classifications and allows comparison between bank classifications of } \\
\text { the same borrower. } \\
\text { SIA provides information on largest borrowers in the system. Financial information is } \\
\text { collected and analyzed on approximately the } 200 \text { largest borrowers and the borrowers } \\
\text { are classified and provisioned on a centralized basis. } \\
\text { SIGAS is a supervisory information system where all the information on supervisory } \\
\text { activities is maintained on an individual basis for each institution. }\end{array}$ \\
\hline \multicolumn{2}{|l|}{$\begin{array}{l}\text { Additional } \\
\text { criteria }\end{array}$} \\
\hline AC1 & $\begin{array}{l}\text { The supervisor employs a well-defined methodology designed to establish a forward- } \\
\text { looking view on the risk profile of banks, positioning the supervisor better to address } \\
\text { proactively any serious threat to the stability of the banking system from any current or } \\
\text { emerging risks. }\end{array}$ \\
\hline $\begin{array}{l}\text { Description and } \\
\text { findings re } A C 1\end{array}$ & $\begin{array}{l}\text { The BdE takes a forward looking approach to risk in the preparation of the risk matrix. } \\
\text { The Risks are rated as growing, stable or decreasing and allows the BdE to project } \\
\text { supervisory activities based on the risk trends. }\end{array}$ \\
\hline $\begin{array}{l}\text { Assessment of } \\
\text { Principle } 19\end{array}$ & Compliant \\
\hline Comments & \\
\hline
\end{tabular}




\begin{tabular}{|c|c|}
\hline Principle 20. & $\begin{array}{l}\text { Supervisory techniques. An effective banking supervisory system should consist of } \\
\text { on-site and off-site supervision and regular contacts with bank management. }\end{array}$ \\
\hline \multicolumn{2}{|l|}{$\begin{array}{l}\text { Essential } \\
\text { criteria }\end{array}$} \\
\hline EC1 & $\begin{array}{l}\text { The supervisor employs an appropriate mix of on-site and off-site supervision to } \\
\text { evaluate the condition of banks, their inherent risks, and the corrective measures } \\
\text { necessary to address supervisory concerns. The specific mix may be determined by } \\
\text { the particular conditions and circumstances of the country. The supervisor has policies } \\
\text { and processes in place to assess the quality, effectiveness and integration of on-site } \\
\text { and off-site functions, and to address any weaknesses that are identified. }\end{array}$ \\
\hline $\begin{array}{l}\text { Description and } \\
\text { findings re EC1 }\end{array}$ & $\begin{array}{l}\text { As part of its ongoing supervisory process the BdE performs three types of } \\
\text { supervisory activities: offsite monitoring, onsite inspections and onsite continuous } \\
\text { supervision. The BdE determines the appropriate mix of activities for each institution } \\
\text { based on the risk profile. The BdE supervisory approach relies on frequent onsite } \\
\text { inspections and offsite reviews, maintain frequent contact with the banks, risk-based } \\
\text { scope of supervision. Resources are approximately distributed as } 25 \text { percent on } \\
\text { offsite, } 30 \text { percent onsite and } 30 \text { percent on permanent onsite supervision at the large } \\
\text { banks. }\end{array}$ \\
\hline EC2 & $\begin{array}{l}\text { The supervisor has in place a coherent process for planning and executing on-site and } \\
\text { off-site activities. There are policies and processes in place to ensure that such } \\
\text { activities are conducted on a thorough and consistent basis with clear responsibilities, } \\
\text { objectives and outputs, and that there is effective coordination and information sharing } \\
\text { between the on-site and off-site functions. }\end{array}$ \\
\hline $\begin{array}{l}\text { Description and } \\
\text { findings re EC2 }\end{array}$ & $\begin{array}{l}\text { BdE Internal Circular of October } 26,2011 \text { provides internal guidance on the planning } \\
\text { of supervisory activities and also provides guidance for the annual plans which sets } \\
\text { the activity for each bank. The circular the circular also describes the internal follow-up } \\
\text { mechanisms after the report of inspection is completed. } \\
\text { Used in conjunction with the BdE Supervision Model document the BdE has a } \\
\text { comprehensive supervision planning and control system. }\end{array}$ \\
\hline EC3 & $\begin{array}{l}\text { On-site work, conducted either by the supervisor's own staff or through the work of } \\
\text { external experts, is used as a tool to: } \\
\text { - provide independent verification that adequate corporate governance (including } \\
\text { risk management and internal control systems) exists at individual banks; } \\
\text { - determine that information provided by banks is reliable; } \\
\text { - obtain additional information on the bank and its related companies needed for } \\
\text { the assessment of the condition of the bank, the evaluation of material risks, and } \\
\text { the identification of necessary remedial actions and supervisory actions, } \\
\text { including enhanced off-site monitoring; and } \\
\text { - monitor the bank's follow-up on supervisory concerns. }\end{array}$ \\
\hline $\begin{array}{l}\text { Description and } \\
\text { findings re EC3 }\end{array}$ & $\begin{array}{l}\text { The onsite inspections increase the knowledge of the risk management and asset } \\
\text { valuation practices, verification of the degree of compliance with regulations and a } \\
\text { review of policies and procedures adopted by the Board. The BdE conducts targeted } \\
\text { and full scope onsite inspections. The targeted inspections focus on risk areas where } \\
\text { information is needed before the general inspection. Targeted inspections are also } \\
\text { used to conduct horizontal reviews of risk areas and assess the risk in the banking } \\
\text { system, for example, commercial real estate reviews. }\end{array}$ \\
\hline
\end{tabular}




\begin{tabular}{|c|c|}
\hline & $\begin{array}{l}\text { The work of the BdE is supplemented by the work of the external auditors that as part } \\
\text { of their annual audits prepare a report for BdE on the banks' compliance with } \\
\text { regulations, loan classification and provisioning and the accuracy or regulatory reports. }\end{array}$ \\
\hline EC4 & $\begin{array}{l}\text { Off-site work is used as a tool to: } \\
\text { - } \quad \text { regularly review and analyse the financial condition of individual banks using } \\
\text { prudential reports, statistical returns and other appropriate information, including } \\
\text { publicly available information; } \\
\text { - follow up on matters requiring further attention, evaluate developing risks and } \\
\text { help identify the priorities and scope of further work; and } \\
\text { - help determine the priorities and scope of on-site work. }\end{array}$ \\
\hline $\begin{array}{l}\text { Description and } \\
\text { findings re EC4 }\end{array}$ & $\begin{array}{l}\text { Teams are assigned particular banks for offsite monitoring. The basic sources of } \\
\text { information are the financial regulatory reports filed by the banks and reports filed for } \\
\text { the central credit registry. The information is supplemented by special requests to the } \\
\text { bank that may include management reports or targeted requests on liquidity, credit } \\
\text { risk, etc. } \\
\text { The BdE does not have a separate department for offsite work, the offsite analysts are } \\
\text { integrated in the supervisory teams. } \\
\text { As a result of off-site monitoring and analysis, the institution's risk matrix and } \\
\text { supervisory risk profile are updated as required. If required, targeted inspections may } \\
\text { be scheduled or bank management contacted to address issues. }\end{array}$ \\
\hline EC5 & $\begin{array}{l}\text { Based on the risk profile of individual banks, the supervisor maintains sufficiently } \\
\text { frequent contacts as appropriate with the bank's Board, non-executive directors, Audit } \\
\text { Committee and senior and middle management (including heads of individual } \\
\text { business units and control functions) to develop an understanding of and assess such } \\
\text { matters as strategy, group structure, corporate governance, performance, capital } \\
\text { adequacy, liquidity, asset quality and risk management systems. }\end{array}$ \\
\hline $\begin{array}{l}\text { Description and } \\
\text { findings re EC5 }\end{array}$ & $\begin{array}{l}\text { The BdE keeps close contact with the banks as a result of its onsite and offsite } \\
\text { activities. For } 16 \text { banks, the BdE has a constant onsite presence. } \\
\text { As part of continuous monitoring the BdE: monitors earnings, credit, IRR, exchange, } \\
\text { liquidity and market risks. The review covers the conglomerate not just the banks. } \\
\text { Internal audit is also reviewed as is corporate governance. }\end{array}$ \\
\hline EC6 & $\begin{array}{l}\text { On an ongoing basis during on-site and off-site supervisory activities, the supervisor } \\
\text { considers the quality of the Board and management. }\end{array}$ \\
\hline $\begin{array}{l}\text { Description and } \\
\text { findings re EC6 }\end{array}$ & $\begin{array}{l}\text { The BdE reviews: } \\
\text { - The suitability of the composition, functions and responsibilities, organizational } \\
\text { rules and powers invested in and delegated by the Board. } \\
\text { - How the Board manages and monitors risk through policies, procedures and } \\
\text { reporting. } \\
\text { - The adequacy of risk management systems in relation to the bank risk profile. } \\
\text { - } \text { - Adequacy of internal audit scope and resources allocated to it. } \\
\text { - Adequacy of policies and procedures adopted by the Board and the level of }\end{array}$ \\
\hline
\end{tabular}




\begin{tabular}{|c|c|}
\hline & implementation by management. \\
\hline EC7 & $\begin{array}{l}\text { The supervisor evaluates the work of the bank's internal audit function, and } \\
\text { determines whether, and to what extent, it may rely on the internal auditors' work to } \\
\text { identify areas of potential risk. }\end{array}$ \\
\hline $\begin{array}{l}\text { Description and } \\
\text { findings re EC7 }\end{array}$ & $\begin{array}{l}\text { In its ICAAP reporting the banks address the internal audit function and the areas } \\
\text { reviewed. Also the main conclusions from the internal audit reports, the deficiencies } \\
\text { and corrective action recommended. Also included in the report must be the unit } \\
\text { (Board, audit committee) to which the internal audit reports are addressed. } \\
\text { The report concludes with an assessment of the suitability of the internal audit function } \\
\text { and the resources assigned to it in respect of the tasks assigned to it and the bank } \\
\text { risks. This report is reviewed by the BdE and confirmed through onsite inspections. } \\
\text { During onsite inspections the inspectors meet with the internal auditor to review the } \\
\text { scope of annual audits, audit results, work papers and ensure independence. }\end{array}$ \\
\hline EC8 & $\begin{array}{l}\text { The supervisor communicates to the bank the findings of its on- and off-site } \\
\text { supervisory analyses by means of written reports or through discussions or meetings } \\
\text { with management. }\end{array}$ \\
\hline $\begin{array}{l}\text { Description and } \\
\text { findings re EC8 }\end{array}$ & $\begin{array}{l}\text { The process for communication with the bank is not fully documented in the BdE } \\
\text { internal governance circulars. There is communication with the bank during the } \\
\text { inspection and at the conclusion. At the conclusion, the inspector may leave a list of } \\
\text { deficiencies with the bank but this is not recognized as an official document. The } \\
\text { official communication to the bank is in the form of a letter from the Director General } \\
\text { for Supervision and approved by the Executive Committee of the BdE. }\end{array}$ \\
\hline \multicolumn{2}{|l|}{$\begin{array}{l}\text { Additional } \\
\text { criteria }\end{array}$} \\
\hline AC1 & $\begin{array}{l}\text { The supervisor meets periodically with senior management and the Board to discuss } \\
\text { the results of supervisory examinations and the external audit. The supervisor should } \\
\text { also meet separately with the independent Board members, as necessary. }\end{array}$ \\
\hline $\begin{array}{l}\text { Description and } \\
\text { findings re } A C 1\end{array}$ & $\begin{array}{l}\text { The inspectors do not meet regularly with the Board but only when it is deemed } \\
\text { necessary. Meetings with senior management are part of the regular supervisory } \\
\text { process. The continuous onsite presence at the larger institutions provides increased } \\
\text { interactions. }\end{array}$ \\
\hline $\begin{array}{l}\text { Assessment of } \\
\text { Principle } 20\end{array}$ & Compliant \\
\hline \multicolumn{2}{|l|}{ Comments } \\
\hline Principle 21. & $\begin{array}{l}\text { Supervisory reporting. Supervisors must have a means of collecting, reviewing and } \\
\text { analyzing prudential reports and statistical returns from banks on both a solo and a } \\
\text { consolidated basis, and a means of independent verification of these reports, through } \\
\text { either on-site examinations or use of external experts. }\end{array}$ \\
\hline \multicolumn{2}{|l|}{$\begin{array}{l}\text { Essential } \\
\text { criteria }\end{array}$} \\
\hline EC1 & $\begin{array}{l}\text { The supervisor has the power to require banks to submit information, on both a solo } \\
\text { and a consolidated basis, on their financial condition, performance, and risks, at } \\
\text { regular intervals. These reports provide information on such matters as on- and off- } \\
\text { balance sheet assets and liabilities, profit and loss, capital adequacy, liquidity, large } \\
\text { exposures, asset concentrations (including by economic sector, geography and } \\
\text { currency), asset quality, loan loss provisioning, related party transactions, IRR and } \\
\text { market risk. }\end{array}$ \\
\hline Description and & Law 26/1988 on disciplining and intervening banks; implemented through Circular \\
\hline
\end{tabular}




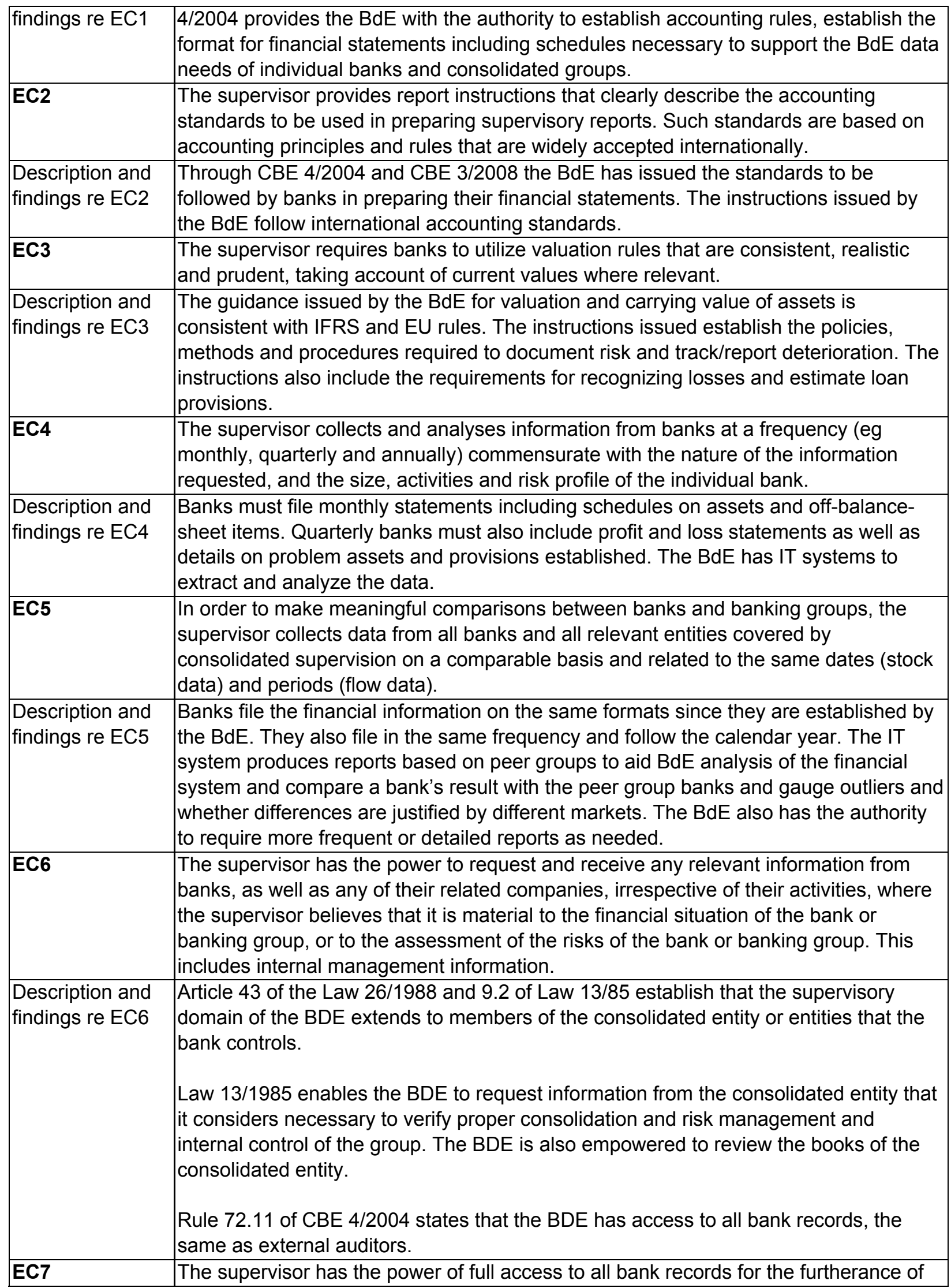




\begin{tabular}{|c|c|}
\hline & $\begin{array}{l}\text { supervisory work. The supervisor also has similar access to the bank's Board, } \\
\text { management and staff, when required. }\end{array}$ \\
\hline $\begin{array}{l}\text { Description and } \\
\text { findings re EC7 }\end{array}$ & $\begin{array}{l}\text { Rule } 72.11 \text { of CBE } 4 / 2004 \text { grants full access to bank records to the BDE. The BDE } \\
\text { has access to the Board and management to discuss any issues concerning the bank. } \\
\text { A review of the BdE supervisory process disclosed frequent interaction with bank } \\
\text { management. Board access is undertaken when warranted by gravity of issues. }\end{array}$ \\
\hline EC8 & $\begin{array}{l}\text { The supervisor has a means of enforcing compliance with the requirement that the } \\
\text { information be submitted on a timely and accurate basis. The supervisor determines } \\
\text { that the appropriate level of senior management is responsible for the accuracy of } \\
\text { supervisory returns, can impose penalties for misreporting and persistent errors, and } \\
\text { can require that inaccurate information be amended. }\end{array}$ \\
\hline $\begin{array}{l}\text { Description and } \\
\text { findings re EC8 }\end{array}$ & $\begin{array}{l}\text { Articles } 4 \mathrm{i} \text { and } 5 \mathrm{i} \text { of Law } 26 / 1988 \text { establish that the failure to submit accurate and } \\
\text { timely reports is a violation of law. Chapter III of the Law establishes the possible } \\
\text { sanctions applicable to banks for the failure to comply. } \\
\text { Directors are assigned responsibility for the accuracy of submitted financial } \\
\text { information and are personally liable. }\end{array}$ \\
\hline EC9 & $\begin{array}{l}\text { The supervisor utilizes policies and processes to confirm the validity and integrity of } \\
\text { supervisory information. This includes a program for the periodic verification of } \\
\text { supervisory returns by means either of the supervisor's own staff or of external } \\
\text { experts. }\end{array}$ \\
\hline $\begin{array}{l}\text { Description and } \\
\text { findings re EC9 }\end{array}$ & $\begin{array}{l}\text { The information received is verified by the Financial Information Department of the } \\
\text { BdE. The information is also verified by the onsite and offsite supervisory staff. } \\
\text { External auditors are also required to verify the accuracy of financial reports submitted } \\
\text { to the BdE during their annual audits. }\end{array}$ \\
\hline EC10 & $\begin{array}{l}\text { The supervisor clearly defines and documents the roles and responsibilities of external } \\
\text { experts, including the scope of the work, when they are appointed to conduct } \\
\text { supervisory tasks and monitors the quality of the work. External experts may be } \\
\text { utilized for routine validation or to examine specific aspects of banks' operations. }\end{array}$ \\
\hline $\begin{array}{l}\text { Description and } \\
\text { findings re EC10 }\end{array}$ & $\begin{array}{l}\text { The BdE relies on its own staff for supervisory reviews. On certain occasions the BdE } \\
\text { has asked for special reports, this has been done by asking the banks to hire external } \\
\text { auditors. }\end{array}$ \\
\hline EC11 & $\begin{array}{l}\text { The supervisor requires that external experts bring to its attention promptly any } \\
\text { material shortcomings identified during the course of any work undertaken by them for } \\
\text { supervisory purposes. }\end{array}$ \\
\hline $\begin{array}{l}\text { Description and } \\
\text { findings re EC11 }\end{array}$ & $\begin{array}{l}\text { The BdE only rarely uses external auditors to conduct special studies. When these } \\
\text { occur, the information collected is to be forwarded to the BdE. Additionally, auditors } \\
\text { verify the financial reports submitted to BdE and inform BdE of discrepancies. }\end{array}$ \\
\hline $\begin{array}{l}\text { Assessment of } \\
\text { Principle } 21\end{array}$ & Compliant \\
\hline \multicolumn{2}{|l|}{ Comments } \\
\hline Principle 22. & $\begin{array}{l}\text { Accounting and disclosure. Supervisors must be satisfied that each bank maintains } \\
\text { adequate records drawn up in accordance with accounting policies and practices that } \\
\text { are widely accepted internationally, and publishes, on a regular basis, information that } \\
\text { fairly reflects its financial condition and profitability. }\end{array}$ \\
\hline \multicolumn{2}{|l|}{$\begin{array}{l}\text { Essential } \\
\text { criteria }\end{array}$} \\
\hline EC1 & $\begin{array}{l}\text { The supervisor has the power to hold bank management and the bank's Board } \\
\text { responsible for ensuring that financial record-keeping systems and the data they } \\
\text { produce are reliable. }\end{array}$ \\
\hline
\end{tabular}




\begin{tabular}{|c|c|}
\hline $\begin{array}{l}\text { Description and } \\
\text { findings re EC1 }\end{array}$ & $\begin{array}{l}\text { Senior management is responsible for ensuring that financial statements reflect at all } \\
\text { times the true condition and are prepared in accordance with accounting standards } \\
\text { and for setting in place the procedures for maintaining the necessary documentation } \\
\text { supporting the financial statements. The Board responsibility also includes ensuring } \\
\text { that the external auditors have full access to all relevant information that may enable } \\
\text { them to issue an opinion. } \\
\text { Article } 1.1 \text { Law } 26 / 1988 \text { includes Board members and management as subject to } \\
\text { sanctioning as a result of violations. Article } 4 \text { Law } 26 / 1988 \text { makes it a sanctionable } \\
\text { violation the failure to maintain records or to maintain records that are not accurate to } \\
\text { ensure that the financial statements reflect the true condition of the bank. }\end{array}$ \\
\hline EC2 & $\begin{array}{l}\text { The supervisor has the power to hold bank management and the bank's Board } \\
\text { responsible for ensuring that the financial statements issued annually to the public } \\
\text { receive proper external verification and bear an external auditor's opinion. }\end{array}$ \\
\hline $\begin{array}{l}\text { Description and } \\
\text { findings re EC2 }\end{array}$ & $\begin{array}{l}\text { The BdE has the authority and sanctioning power to enforce the external audit } \\
\text { requirement. Also the Securities regulator is responsible for verifying that public } \\
\text { disclosures are adequate. }\end{array}$ \\
\hline EC3 & $\begin{array}{l}\text { The supervisor requires banks to utilize valuation rules that are consistent, realistic } \\
\text { and prudent, taking account of current values where relevant, and to show profits net } \\
\text { of appropriate provisions. }\end{array}$ \\
\hline $\begin{array}{l}\text { Description and } \\
\text { findings re EC3 }\end{array}$ & $\begin{array}{l}\text { In its supervisory process the BdE reviews the accounting policies and the criteria for } \\
\text { valuing assets and capital. Also verified are loan provisioning levels to ensure capital } \\
\text { is not overstated based on overvalued assets. } \\
\text { CBE } 4 / 2004 \text { establishes the requirements for valuing assets and compliance is } \\
\text { reviewed by the BDE. }\end{array}$ \\
\hline EC4 & $\begin{array}{l}\text { Laws or regulations set, or the supervisor has the power, in appropriate } \\
\text { circumstances, to establish, the scope of external audits of individual banks and the } \\
\text { standards to be followed in performing such audits. }\end{array}$ \\
\hline $\begin{array}{l}\text { Description and } \\
\text { findings re EC4 }\end{array}$ & $\begin{array}{l}\text { Statutory audits of financial statements must be performed in compliance with RDL } \\
1 / 2011 \text { on statutory audits, Regulation } 1517 / 2011 \text { which develops it and the binding } \\
\text { Audit Technical Standards published by the Spanish Institute of Accounting and Audit } \\
\text { (ICAC). }\end{array}$ \\
\hline EC5 & $\begin{array}{l}\text { Supervisory guidelines or local auditing standards determine that audits cover such } \\
\text { areas as the loan portfolio, loan loss reserves, non-performing assets, asset } \\
\text { valuations, trading and other securities activities, derivatives, asset securitizations, } \\
\text { and the adequacy of internal controls over financial reporting. }\end{array}$ \\
\hline $\begin{array}{l}\text { Description and } \\
\text { findings re EC5 }\end{array}$ & $\begin{array}{l}\text { The scope of the audits is established by the Spanish Audit Technical Standards and } \\
\text { is published in the ICAC website. Article } 5 \text { of regulation } 1517 / 2011 \text { establishes the } \\
\text { minimum content for audit reports. All areas listed in EC5 are addressed. }\end{array}$ \\
\hline EC6 & $\begin{array}{l}\text { The supervisor has the power to reject and rescind the appointment of an external } \\
\text { auditor that is deemed to have inadequate expertise or independence, or not to be } \\
\text { subject to or not to follow established professional standards. }\end{array}$ \\
\hline $\begin{array}{l}\text { Description and } \\
\text { findings re EC6 }\end{array}$ & $\begin{array}{l}\text { BdE does not have the legal authority to reject or rescind the appointment of an } \\
\text { external auditor of a bank. However, as the standard setter for the banking accounting } \\
\text { and its participation in the Audit Committee and the Advisory Committee of the ICAC } \\
\text { the BdE can impose supervisory actions and suspend auditors when determined } \\
\text { unqualified or not meeting an adequate scope in the institution audited. }\end{array}$ \\
\hline EC7 & $\begin{array}{l}\text { The supervisor requires banks to produce annual audited financial statements based } \\
\text { on accounting principles and rules that are widely accepted internationally and have }\end{array}$ \\
\hline
\end{tabular}




\begin{tabular}{|c|c|}
\hline & $\begin{array}{l}\text { been audited in accordance with internationally accepted auditing practices and } \\
\text { standards. }\end{array}$ \\
\hline $\begin{array}{l}\text { Description and } \\
\text { findings re EC7 }\end{array}$ & $\begin{array}{l}\text { Royal Decree } 1 / 2011 \text { requires that all banks' annual financial statement be subject to } \\
\text { an external audit. } \\
\text { External audit must be in compliance with applicable audit regulations, which include } \\
\text { international audit standards adopted by the EU. The audit must also meet the } \\
\text { Spanish Audit Technical Standards which are in line with international standards of } \\
\text { audits. }\end{array}$ \\
\hline EC8 & $\begin{array}{l}\text { Laws, regulations or the supervisor require periodic public disclosures of information } \\
\text { by banks that adequately reflect the bank's true financial condition. The requirements } \\
\text { imposed should promote the comparability, relevance, reliability and timeliness of the } \\
\text { information disclosed. }\end{array}$ \\
\hline $\begin{array}{l}\text { Description and } \\
\text { findings re EC8 }\end{array}$ & $\begin{array}{l}\text { Circular 4/2004 (Rules 59-62) requires a management narrative/notes expanding on } \\
\text { the balance sheet information; profit and loss, capital reconcilement and funds flows. } \\
\text { CBE } 3 / 2008 \text { also addresses the information to be disclosed and the format. }\end{array}$ \\
\hline EC9 & $\begin{array}{l}\text { The required disclosures include both qualitative and quantitative information on a } \\
\text { bank's financial performance, financial position, risk management strategies and } \\
\text { practices, risk exposures, transactions with related parties, accounting policies, and } \\
\text { basic business, management and governance. The scope and content of information } \\
\text { provided and the level of disaggregation and detail should be commensurate with the } \\
\text { size and complexity of a bank's operations. }\end{array}$ \\
\hline $\begin{array}{l}\text { Description and } \\
\text { findings re EC9 }\end{array}$ & $\begin{array}{l}\text { CBE 4/2004 requires banks to disclose in their financial statement notes the following: } \\
\text { (1) Exposure to market risk, credit and liquidity. (2) The policies and goals of risk } \\
\text { management. (3) Subsequent events. (4). Transactions with related parties. } \\
\text { (5) Disclose related parties, entities and the nature of the relation. } \\
\text { CBE } 3 / 2008 \text { follows Basel II, Pillar } 3 \text { disclosures. }\end{array}$ \\
\hline EC10 & $\begin{array}{l}\text { Laws, regulations or the supervisor provide effective review and enforcement } \\
\text { mechanisms designed to confirm compliance with disclosure standards. }\end{array}$ \\
\hline $\begin{array}{l}\text { Description and } \\
\text { findings re EC10 }\end{array}$ & $\begin{array}{l}\text { Royal decree } 1 / 2011 \text { requires that all published financial statements be subject to } \\
\text { audit to ensure compliance with disclosure requirements and making sure that } \\
\text { information disclosed is accurate. }\end{array}$ \\
\hline EC11 & $\begin{array}{l}\text { The supervisor or other relevant bodies publish aggregate information on the banking } \\
\text { system to facilitate public understanding of the banking system and the exercise of } \\
\text { market discipline. Such information includes aggregate data on balance sheet } \\
\text { indicators and statistical parameters that reflect the principal aspects of banks' } \\
\text { operations (balance sheet structure, capital ratios, income earning capacity, and risk } \\
\text { profiles). }\end{array}$ \\
\hline $\begin{array}{l}\text { Description and } \\
\text { findings re EC11 }\end{array}$ & $\begin{array}{l}\text { The BdE publishes a number of documents providing information on the financial } \\
\text { system. These publications include the Statistical Bulletin, The Financial Stability } \\
\text { Report and the Banking supervision in which aggregate information on solvency and } \\
\text { profitability is published. }\end{array}$ \\
\hline \multicolumn{2}{|l|}{\begin{tabular}{|l|l|l} 
Additional \\
criteria
\end{tabular}} \\
\hline AC1 & $\begin{array}{l}\text { The supervisor meets periodically with external audit firms to discuss issues of } \\
\text { common interest relating to bank operations. }\end{array}$ \\
\hline $\begin{array}{l}\text { Description and } \\
\text { findings re } A C 1\end{array}$ & $\begin{array}{l}\text { The BdE holds annual meetings with the major audit firms. In addition, there are } \\
\text { ongoing communications between the firms and BdE inspectors. }\end{array}$ \\
\hline AC2 & External auditors, whether or not utilized by the supervisor for supervisory purposes, \\
\hline
\end{tabular}




\begin{tabular}{|c|c|}
\hline & $\begin{array}{l}\text { have the duty to report to the supervisor matters of material significance, for example } \\
\text { failure to comply with the licensing criteria or breaches of banking or other laws, or } \\
\text { other matters which they believe are likely to be of material significance to the } \\
\text { functions of the supervisor. Laws or regulations ensure that auditors who make any } \\
\text { such reports in good faith cannot be held liable for breach of a duty of confidentiality. }\end{array}$ \\
\hline $\begin{array}{l}\text { Description and } \\
\text { findings re AC2 }\end{array}$ & $\begin{array}{l}\text { The duty of alerting BdE is regulated by RDL } 1 / 2011 \text { in compliance with EU directive. } \\
\text { External auditors shall communicate without delay (within } 10 \text { days) in writing to the } \\
\text { BdE on any significant events uncovered in an audit. }\end{array}$ \\
\hline AC3 & $\begin{array}{l}\text { Laws, regulations or the supervisor require banks to rotate their external auditors } \\
\text { (either the firm or individuals within the firm) from time to time. }\end{array}$ \\
\hline $\begin{array}{l}\text { Description and } \\
\text { findings re AC3 }\end{array}$ & $\begin{array}{l}\text { Article } 19.2 \mathrm{RDL} 1 / 2011 \text { established a seven-year rotational requirement for audit } \\
\text { partners of a firm and a two year cooling off period. }\end{array}$ \\
\hline AC4 & The supervisor requires banks to have a formal disclosure policy. \\
\hline $\begin{array}{l}\text { Description and } \\
\text { findings re AC4 }\end{array}$ & $\begin{array}{l}\text { Rule of CBE 4/2004 requires banks to have a written disclosure policy. The BDE } \\
\text { during its reviews of accounting practices reviews compliance with the requirement. }\end{array}$ \\
\hline AC5 & $\begin{array}{l}\text { The supervisor has the power to access external auditors' working papers, where } \\
\text { necessary. }\end{array}$ \\
\hline $\begin{array}{l}\text { Description and } \\
\text { findings re AC5 }\end{array}$ & $\begin{array}{l}\text { According to RDL } 1 / 2011 \text { and Article } 25.2 d \text { Audit Regulation } 1517 / 2011 \text {, BDE has the } \\
\text { authority to review working papers for supervisory purposes. }\end{array}$ \\
\hline $\begin{array}{l}\text { Assessment of } \\
\text { Principle } 22\end{array}$ & Compliant \\
\hline \multicolumn{2}{|l|}{ Comments } \\
\hline Principle 23. & $\begin{array}{l}\text { Corrective and remedial powers of supervisors. Supervisors must have at their } \\
\text { disposal an adequate range of supervisory tools to bring about timely corrective } \\
\text { actions. This includes the ability, where appropriate, to revoke the banking license or } \\
\text { to recommend its revocation. }\end{array}$ \\
\hline \multicolumn{2}{|l|}{$\begin{array}{l}\text { Essential } \\
\text { criteria }\end{array}$} \\
\hline EC1 & $\begin{array}{l}\text { The supervisor raises supervisory concerns with management or, where appropriate, } \\
\text { the Board, at an early stage, and requires that these concerns are addressed in a } \\
\text { timely manner. Where the supervisor requires the bank to take significant remedial } \\
\text { actions, these are addressed in a written document to the Board. The supervisor } \\
\text { requires the bank to submit regular written progress reports and checks that remedial } \\
\text { actions are completed satisfactorily. }\end{array}$ \\
\hline $\begin{array}{l}\text { Description and } \\
\text { findings re EC1 }\end{array}$ & $\begin{array}{l}\text { As a result of its supervisory activity, the BdE will have written communication with the } \\
\text { banks and the Board concerning issues that warrant follow-up by the bank. These } \\
\text { communications are in the form of: (1) Letter of Recommendation. (2) Letter of } \\
\text { Requirements. Both types of letters are addressed to the Board. A letter of } \\
\text { recommendation recommends a specific course of action. A letter of requirements is } \\
\text { binding and, therefore a failure to meet it can constitute a serious or a very serious } \\
\text { infraction. Both letters are signed by the Director General for Supervision after } \\
\text { approval by the Executive Committee. The supervisory process is fully developed and } \\
\text { ensures that the letters are generally sent in a timely fashion following the supervisory } \\
\text { activity. } \\
\text { At the conclusion of an inspection the inspector in charge will communicate to the } \\
\text { bank management the findings. The inspector may leave a list of deficiencies but this } \\
\text { is not a requirement and the deficiencies may be communicated orally. As the } \\
\text { elaboration of the very comprehensive and detailed inspection report necessarily takes } \\
\text { some time, requiring that the list of deficiencies always be left in writing would }\end{array}$ \\
\hline
\end{tabular}




\begin{tabular}{|c|c|}
\hline & $\begin{array}{l}\text { encourage the bank to commence the addressing of deficiencies earlier and improve } \\
\text { transparency and audit trail. } \\
\text { A review of the BdE process demonstrated a documented and standardized system to } \\
\text { ensure follow-up. } \\
\text { Under Article } 23.1 \text { (f) of Law } 13 / 1994 \text {, the BdE is empowered to make } \\
\text { recommendations and require corrective action from banks. } \\
\text { Article } 11 \text { of Law } 13 / 1985 \text { empowers the BdE to impose requirements on a bank for } \\
\text { failing to comply with capital adequacy regulations, lacking adequate organizational } \\
\text { structure, or internal controls. Such requirements must be made in writing and } \\
\text { reported to the Board of directors. } \\
\text { Article } 75 \text {; Royal Decree } 216 / 2008 \text {, if a bank fails to comply with capital adequacy } \\
\text { requirements it must immediately inform the BdE and submit a plan on how it will } \\
\text { restore capital adequacy. } \\
\text { Articles } 4,5 \text {, and } 6 \text { of LDI: failure of the bank to comply with BdE requirements will } \\
\text { result in a violation of law. The articles also provide the BdE authority to apply } \\
\text { sanctions for failure to implement adequate corporate governance since those } \\
\text { requirements are stated in law. }\end{array}$ \\
\hline EC2 & $\begin{array}{l}\text { The supervisor participates in deciding when and how to effect the orderly resolution } \\
\text { of a problem bank situation (which could include closure, or assisting in restructuring, } \\
\text { or merger with a stronger institution). }\end{array}$ \\
\hline & $\begin{array}{l}\text { The BdE is responsible for making the determination of when a bank needs resolution. } \\
\text { After the bank enters the liquidating or restructuring process with the involvement of } \\
\text { FROB or DGS, the BdE remains a part of the process (which is led by the FROB). } \\
\text { Title III; LDI, intervention or temporary replacement of the Board or management in } \\
\text { problem bank situations set out in Article } 31 \text { LDI can be decided by the BdE after } \\
\text { detecting a grave situation. BdE must give a reasoned account of its decision to the } \\
\text { MoE. Liquidations/withdrawal of the license is proposed by the MoE (based on BdE } \\
\text { recommendation) and must be approved by the Council of Ministers except for certain } \\
\text { cases (e.g., withdrawal adopted directly by the MoE due to the opening of a court } \\
\text { liquidation proceeding). (See CP } 1.4 \text { ). } \\
\text { Article } 7 \text { of Royal Decree-law } 16 / 2011 \text { on the deposit insurance scheme (DGS): The } \\
\text { BdE controls } 6 \text { of the } 12 \text { members of the management body. The DGS has two } \\
\text { functions: guarantee deposits (Articles. } 8 \text { to } 10 \text { Royal Decree-Law } 16 / 2011 \text { ) and } \\
\text { strengthen the solvency and performance of the banks (Article. } 11 \text { to } 13 \text { Royal } \\
\text { Decree-Law } 16 / 2011 \text { ). The DGS may lend financial assistance to help restructure or } \\
\text { strengthen the bank under a framework of an action plan adopted by the entity and } \\
\text { approved by the BdE. } \\
\text { Article } 7 \text { Royal Decree- law } 9 / 2009 \text {. In the event that a satisfactory solution is not } \\
\text { implemented, the BdE shall take the decision to temporarily replace the Board of } \\
\text { Directors and appoint the FROB as professional director for the bank. }\end{array}$ \\
\hline EC3 & $\begin{array}{l}\text { The supervisor has available an appropriate range of supervisory tools for use when, } \\
\text { in the supervisor's judgment, a bank is not complying with laws, regulations or } \\
\text { supervisory decisions, or is engaged in unsafe or unsound practices, or when the }\end{array}$ \\
\hline
\end{tabular}




\begin{tabular}{|c|c|}
\hline & $\begin{array}{l}\text { interests of depositors are otherwise threatened. These tools include the ability to } \\
\text { require a bank to take prompt remedial action and to impose penalties. In practice, the } \\
\text { range of tools is applied in accordance with the gravity of a situation. }\end{array}$ \\
\hline $\begin{array}{l}\text { Description and } \\
\text { findings re EC3 }\end{array}$ & 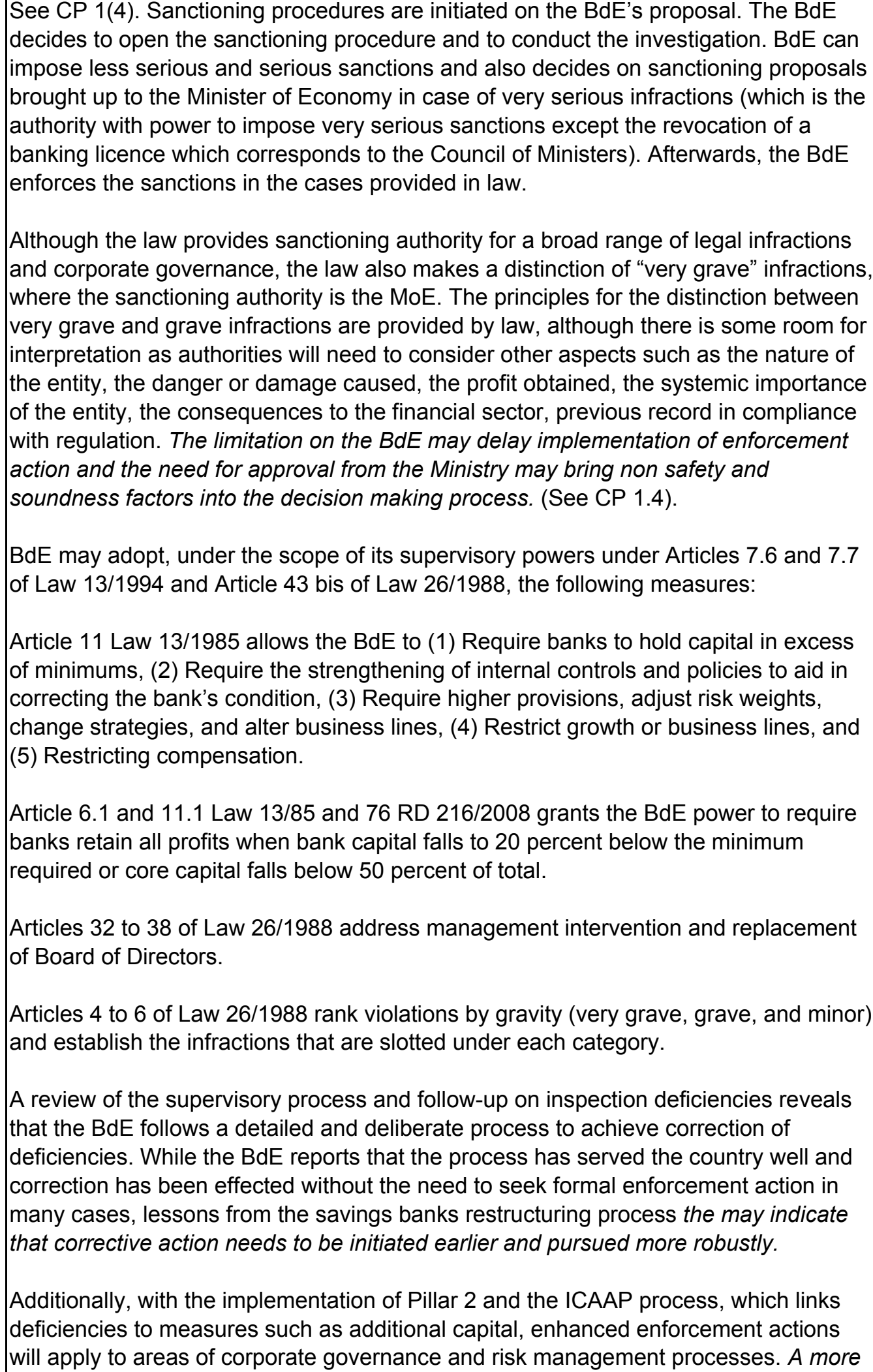 \\
\hline
\end{tabular}




\begin{tabular}{|c|c|}
\hline & $\begin{array}{l}\text { detailed enforcement action program should be developed to facilitate their } \\
\text { enforcement. }\end{array}$ \\
\hline EC4 & $\begin{array}{l}\text { The supervisor has available a broad range of possible measures to address such } \\
\text { scenarios as described in EC3 above and provides clear prudential objectives or sets } \\
\text { out the actions to be taken, which may include restricting the current activities of the } \\
\text { bank, withholding approval of new activities or acquisitions, restricting or suspending } \\
\text { payments to shareholders or share repurchases, restricting asset transfers, barring } \\
\text { individuals from banking, replacing or restricting the powers of managers, Board } \\
\text { directors or controlling owners, facilitating a takeover by or merger with a healthier } \\
\text { institution, providing for the interim management of the bank, and revoking or } \\
\text { recommending the revocation of the banking license. }\end{array}$ \\
\hline & $\begin{array}{l}\text { Article } 11 \text { of Law } 13 / 1985 \text { allows the BdE to restrict dividends and opening of } \\
\text { branches, in cases where the bank is not in compliance with solvency regulations. } \\
\text { Law } 26 / 1988 \text { : } \\
\text { Article } 59 \text { addresses BdE power to suspend the rights of shareholders, intervention } \\
\text { and replacement of directors in cases where an acquisition of a significant holding was } \\
\text { acquired without BdE approval. } \\
\text { Article } 62 \text { addresses suspension of voting rights of shareholders that may have a } \\
\text { negative influence on the bank. } \\
\text { Article } 24 \text { allows temporary replacement of directors and management implicated in a } \\
\text { violation while sanctioning procedures are being implemented. Title III addresses the } \\
\text { intervention and replacement of directors if the safety and soundness of the bank are } \\
\text { threatened. } \\
\text { Articles } 75 \text { and } 76 \text { of Decree } 216 / 2008 \text { require banks to promptly notify the BdE when } \\
\text { the bank fails to meet capital standards. The bank must submit a plan on correction. } \\
\text { Dividends can be restricted if capital deficit exceeds } 20 \text { percent or core capital is } \\
\text { below } 50 \text { percent of total capital. } \\
\text { Law } 13 / 1985 \text { authorizes BdE, concerning capital, to: hold capital in excess of } \\
\text { regulatory minimums, enhance capital planning, adjust risk weights or provisioning to } \\
\text { reflect the bank risk profile, limiting asset growth, activities or expansion and restricting } \\
\text { salaries. }\end{array}$ \\
\hline EC5 & $\begin{array}{l}\text { The supervisor has the power to take measures should a bank fall below the minimum } \\
\text { capital ratio, and seeks to intervene at an early stage to prevent capital from falling } \\
\text { below the minimum. The supervisor has a range of options to address such scenarios. }\end{array}$ \\
\hline $\begin{array}{l}\text { Description and } \\
\text { findings re EC5 }\end{array}$ & $\begin{array}{l}\text { Article } 11 \text { Law } 13 / 1985 \text { allows the BdE to (1) Require banks to hold capital in excess } \\
\text { of minimums, (2) Require the strengthening of internal controls and policies to aid in } \\
\text { correcting the bank's condition, (3) Require higher provisions, adjust risk weights, } \\
\text { change strategies, and alter business lines, (4) Restrict growth or business lines, and } \\
\text { (5) Restricting compensation. } \\
\text { Article } 6.1 \text { and } 11.1 \text { Law } 13 / 85 \text { and } 76 \text { RD } 216 / 2008 \text { grants the BdE power to require } \\
\text { banks retain all profits when bank capital fall } 20 \text { percent below the minimum required } \\
\text { or core capital falls below } 50 \text { percent. }\end{array}$ \\
\hline EC6 & lies penalties and sanctions not only to the bank but, when and if \\
\hline
\end{tabular}




\begin{tabular}{|c|c|}
\hline & necessary, also to management and/or the Board, or individuals therein. \\
\hline $\begin{array}{l}\text { Description and } \\
\text { findings re EC6 }\end{array}$ & $\begin{array}{l}\text { Article } 1 \text { Law 26/1988; sanctioning actions apply not only to the bank but also to the } \\
\text { board and management. Articles } 12-13 \text { Law } 26 / 1988 \text { state that fines can be imposed } \\
\text { simultaneously on both the banks and individuals involved in the violation. } \\
\text { Article } 31 \text { Law } 26 / 1988 \text { enables the temporary removal of directors when the safety } \\
\text { and soundness of the bank is at stake. }\end{array}$ \\
\hline \multicolumn{2}{|l|}{$\begin{array}{l}\text { Additional } \\
\text { criteria }\end{array}$} \\
\hline AC1 & $\begin{array}{l}\text { Laws or regulations guard against the supervisor unduly delaying appropriate } \\
\text { corrective actions. }\end{array}$ \\
\hline $\begin{array}{l}\text { Description and } \\
\text { findings re } A C 1\end{array}$ & $\begin{array}{l}\text { Article } 103.1 \text { CE and } 3.1 \text { of Law 30/1992 establish penalties for not acting with } \\
\text { efficiency and also sets time limits for acting on sanctions. }\end{array}$ \\
\hline AC2 & $\begin{array}{l}\text { The supervisor has the power to take remedial actions, including ring-fencing of the } \\
\text { bank from the actions of parent companies, subsidiaries, parallel-owned banking } \\
\text { structures and other related companies in matters that could impair the safety and } \\
\text { soundness of the bank. }\end{array}$ \\
\hline $\begin{array}{l}\text { Description and } \\
\text { findings re AC2 }\end{array}$ & $\begin{array}{l}\text { Article } 1.3 \text { of Law } 26 / 1988 \text { states that all foreign subsidiaries and branches of foreign } \\
\text { banks from third countries are subject to the same enforcement scheme as domestic } \\
\text { banks. The BdE has broad enforcement powers. }\end{array}$ \\
\hline AC3 & $\begin{array}{l}\text { When taking formal remedial action in relation to a bank, the supervisor ensures that } \\
\text { the regulators of non-bank related financial entities are aware of its actions and, where } \\
\text { appropriate, coordinates its actions with them. }\end{array}$ \\
\hline $\begin{array}{l}\text { Description and } \\
\text { findings re AC3 }\end{array}$ & $\begin{array}{l}\text { The BdE has signed a crisis MoU with other authorities and the Financial Stability } \\
\text { Committee (CESFI). Other regulators report that they have been kept informed by the } \\
\text { BdE. }\end{array}$ \\
\hline $\begin{array}{l}\text { Assessment of } \\
\text { Principle } 23\end{array}$ & Largely Compliant \\
\hline Comments & $\begin{array}{l}\text { The BdE has a broad range of supervisory enforcement authority. The process has } \\
\text { worked well for the BdE and the deliberate approach has reduced the need for } \\
\text { sanctions. However, the adoption of new regulations to implement Pillar 2, the current } \\
\text { crisis and the pace at which deterioration can occur in the integrated global market } \\
\text { indicate the need for flexible actions that can be applied at an earlier stage to effect } \\
\text { corrective action. The current process remains primarily linear based on granting the } \\
\text { bank various opportunities for correction. However, such a process must be } \\
\text { augmented by actions, in serious situations, to protect asset values and capital while } \\
\text { the linear process of negotiations continues. In the current crisis and distressed credit } \\
\text { institutions situations, it is unclear whether corrective actions were delayed for } \\
\text { systemic stability concerns, or due to an underestimate of the depth and length of the } \\
\text { economic downturn. An end-result of the process has been the resolution of credit } \\
\text { institutions with mixed results and resulting in banks still in further need of } \\
\text { strengthening. A review of enforcement procedures, including the implementation of } \\
\text { earlier actions such as adding more weight to a written communication from the } \\
\text { inspector at the conclusion of an inspection or supervisory activity at banks with } \\
\text { ongoing supervision. Other possible options may include linking the issuance of letters } \\
\text { of requirement or initiation of enforcement action to risk-based benchmarks such as } \\
\text { the risk matrix measurements of trends and the risk rating assigned to the bank. Also } \\
\text { considered should be the incorporation, primarily in a systemic crisis situation, of } \\
\text { parallel action on individual banks to protect the value of assets and capital (reduce or } \\
\text { eliminate dividends, cancelling lending commitments on existing projects that are in }\end{array}$ \\
\hline
\end{tabular}




\begin{tabular}{|c|c|}
\hline & $\begin{array}{l}\text { doubt and imposing stringent requirements for funding new projects) and minimize } \\
\text { resolution costs. The "Supervisory Guidance on Dealing with Weak Banks" paper from } \\
\text { the BCBS provides a number of options for implementing supervisory action and } \\
\text { developing enforcement tools. }\end{array}$ \\
\hline Principle 24. & $\begin{array}{l}\text { Consolidated supervision. An essential element of banking supervision is that } \\
\text { supervisors supervise the banking group on a consolidated basis, adequately } \\
\text { monitoring and, as appropriate, applying prudential norms to all aspects of the } \\
\text { business conducted by the group worldwide. }\end{array}$ \\
\hline \multicolumn{2}{|l|}{$\begin{array}{l}\text { Essential } \\
\text { criteria }\end{array}$} \\
\hline EC1 & $\begin{array}{l}\text { The supervisor is familiar with the overall structure of banking groups and has an } \\
\text { understanding of the activities of all material parts of these groups, domestic and } \\
\text { cross-border. }\end{array}$ \\
\hline $\begin{array}{l}\text { Description and } \\
\text { findings re EC1 }\end{array}$ & $\begin{array}{l}\text { BdE performs consolidated supervision of banking groups. It gains an in depth } \\
\text { knowledge of the overall structure and activities through detailed regular mandatory } \\
\text { reporting on a solo and consolidated basis from parent banks, and permanent on-site } \\
\text { supervisory teams on the parent banks of the large Spanish banks. Cooperation with } \\
\text { foreign supervisors and regular contacts with managers of foreign banks belonging to } \\
\text { the group play an important role. BdE has signed MoUs with foreign supervisors of } \\
\text { countries where Spanish banks operate and leads the organization of supervisory } \\
\text { colleges as home supervisor, according to applicable regulations. } \\
\text { In addition, starting in 2009, BdE has been implementing in Spain the work of the } \\
\text { FSB's relevant working groups on resolution, which implies an in-depth knowledge of } \\
\text { the corporate structure and inter-linkages of international banking groups. } \\
\text { On the domestic market, the BdE has signed cooperation agreements with insurance, } \\
\text { securities supervisors and with the SEPBLAC. Supervisors exchange information } \\
\text { concerning inspection results. In addition, the BdE has conducted joint inspections } \\
\text { with SEPBLAC. }\end{array}$ \\
\hline EC2 & $\begin{array}{l}\text { The supervisor has the power to review the overall activities of a banking group, both } \\
\text { domestic and cross-border. The supervisor has the power to supervise the foreign } \\
\text { activities of banks incorporated within its jurisdiction. }\end{array}$ \\
\hline $\begin{array}{l}\text { Description and } \\
\text { findings re EC2 }\end{array}$ & $\begin{array}{l}\text { BdE is empowered to supervise banks on a solo and consolidated basis, including all } \\
\text { the offices or entities within the group irrespective of their location or legal structure. } \\
\text { Entities and natural persons subject to BdE's supervision are legally compelled to } \\
\text { have at its disposal all registers, documents, data bases and information BdE may } \\
\text { require (Article } 431 \mathrm{DI}) \text {. } \\
\text { Consolidated supervision is primarily based on the information compiled by the parent } \\
\text { bank in order to manage the risks and controls of the group as a whole. Parent banks } \\
\text { are subject to mandatory detailed regular reporting to the BdE, which also covers } \\
\text { internal global risk management and information on internal controls as needed. }\end{array}$ \\
\hline EC3 & $\begin{array}{l}\text { The supervisor has a supervisory framework that evaluates the risks that non-banking } \\
\text { activities conducted by a bank or banking group may pose to the bank or banking } \\
\text { group. }\end{array}$ \\
\hline $\begin{array}{l}\text { Description and } \\
\text { findings re EC3 }\end{array}$ & $\begin{array}{l}\text { BdE's control powers are extended to nonfinancial institutions of the banking group } \\
\text { when required to comply with its supervisory responsibilities (Article } 43.1 \mathrm{LDI} \text { ). }\end{array}$ \\
\hline
\end{tabular}




\begin{tabular}{|c|c|}
\hline & $\begin{array}{l}\text { groups, as well as their related management and control systems, which are } \\
\text { incorporated in each bank's risk profile. }\end{array}$ \\
\hline EC4 & $\begin{array}{l}\text { The supervisor has the power to impose prudential standards on a consolidated basis } \\
\text { for the banking group. The supervisor uses its power to establish prudential standards } \\
\text { on a consolidated basis to cover such areas as capital adequacy, large exposures, } \\
\text { exposures to related parties and lending limits. The supervisor collects consolidated } \\
\text { financial information for each banking group. }\end{array}$ \\
\hline $\begin{array}{l}\text { Description and } \\
\text { findings re EC4 }\end{array}$ & $\begin{array}{l}\text { Article } 6 \text { Law } 13 / 1985 \text {; Article } 5 \text { RD 216/2008: solvency regulations must be complied } \\
\text { with on a consolidated basis by banking groups. They include: capital adequacy, limits } \\
\text { to large exposures, limits to operations or positions which imply high risks for the } \\
\text { solvency of the group, corporate governance and organizational requirements, internal } \\
\text { capital assessment, risk management policies. } \\
\text { Circular of BDE } 3 / 2008 \text { bases and details legal solvency requirements, including } \\
\text { mandatory reporting to BDE, which must be complied with on a consolidated basis. } \\
\text { The new requirement of a core capital ratio established in RDL } 2 / 2011 \text { must be } \\
\text { complied with on a consolidated basis. } \\
\text { Through Circular } 3 / 2008 \text { BDE bases its powers to impose detailed prudential } \\
\text { standards on a consolidated basis to banking groups. BDE's Circulars are legally } \\
\text { binding and infringements are subject to LDI on discipline and intervention of credit } \\
\text { institutions. } \\
\text { In conducting consolidated supervision the BdE is empowered with the supervision of } \\
\text { credit institutions, which affects all the companies included in their (economic) group. } \\
\text { To that end, BdE can request as much information as deemed necessary and check } \\
\text { its accuracy. }\end{array}$ \\
\hline EC5 & $\begin{array}{l}\text { The supervisor has arrangements with other relevant supervisors, domestic and cross- } \\
\text { border, to receive information on the financial condition and adequacy of risk } \\
\text { management and controls of the different entities of the banking group. }\end{array}$ \\
\hline $\begin{array}{l}\text { Description and } \\
\text { findings re EC5 }\end{array}$ & $\begin{array}{l}\text { BdE has signed MoUs for cooperation and information sharing with the other domestic } \\
\text { sectoral supervisors (CNMV, DGSFP). BdE has also signed MoUs with relevant } \\
\text { foreign supervisors, UE (8) and non-EU (12). BdE has entered into several (Article131 } \\
\text { Capital Requirement Directive) multilateral MoUs. Additionally, BdE participates in } \\
\text { supervisory colleges of international banking groups, acting as home or host } \\
\text { supervisor. BdE also takes part in international cross border crisis management } \\
\text { groups with other banking supervisors. } \\
\text { MoU negotiations with foreign supervisors, include an explicit clause stating that there } \\
\text { should be no hindrance in host countries for the parent bank to have access to all } \\
\text { material information from their branches and subsidiaries, and that information should } \\
\text { be at the disposal of the home supervisory authority, in compliance with confidentiality } \\
\text { requirements }\end{array}$ \\
\hline EC6 & $\begin{array}{l}\text { The supervisor has the power to limit the range of activities the consolidated group } \\
\text { may conduct and the locations in which activities can be conducted; the supervisor } \\
\text { uses this power to determine that the activities are properly supervised and that the } \\
\text { safety and soundness of the bank are not compromised. }\end{array}$ \\
\hline Descriptio & The Spanish regulation on cross-border activities of banking groups (Article13, \\
\hline
\end{tabular}




\begin{tabular}{|c|c|}
\hline findings re EC6 & $\begin{array}{l}\text { Article } 17 \text { RD 1245/1995) requires the authorization of the BdE to open a cross-border } \\
\text { branch or to create or buy a foreign credit institution. In the authorization process, BdE } \\
\text { assesses, among others, whether the activities abroad would be properly supervised } \\
\text { by the local supervisor and whether there would be any limitation to the BdE's } \\
\text { supervision of the banking group on a consolidated basis. Information on the business } \\
\text { plan, organizational structure and fit and properness of managers of intended cross } \\
\text { border activities is legally required in the application to assist BdE's assessment of the } \\
\text { implications the proposed cross border expansion may have on the safety and } \\
\text { soundness of the bank. } \\
\text { BdE is legally empowered to require the applicant to provide any other information it } \\
\text { may deem necessary. In the course of the authorization process, BdE consults local } \\
\text { supervisors, and requires relevant information when necessary. }\end{array}$ \\
\hline EC7 & $\begin{array}{l}\text { The supervisor determines that management is maintaining proper oversight of the } \\
\text { bank's foreign operations, including branches, joint ventures and subsidiaries. The } \\
\text { supervisor also determines that banks' policies and processes ensure that the local } \\
\text { management of any cross-border operations has the necessary expertise to manage } \\
\text { those operations in a safe and sound manner and in compliance with supervisory and } \\
\text { regulatory requirements. }\end{array}$ \\
\hline $\begin{array}{l}\text { Description and } \\
\text { findings re EC7 }\end{array}$ & $\begin{array}{l}\text { Legal requirements to open a cross border branch or to set up/buy a foreign bank, } \\
\text { which include, among others, compliance with fit and proper conditions by local } \\
\text { managers and adequate organizational structure and internal controls of foreign } \\
\text { activities. Any changes in the information provided in the application must be reported } \\
\text { to the BdE (including changes in managers in charge of foreign branches, directors } \\
\text { and shareholder of foreign banks within the banking group), who assesses whether } \\
\text { legal requirements continue to be met with the proposed changes. } \\
\text { Parent banks/head offices are obliged to comply with solvency and risk management } \\
\text { regulations on a consolidated basis. Such regulations include qualitative requirements, } \\
\text { such as adequate organization and internal policies and controls to ensure compliance } \\
\text { across the banking group. BdE supervises such qualitative requirements. (Article.5, } \\
\text { Article } 66 \text { RD } 216 / 2008 \text { ). } \\
\text { Foreign activities are included in the mandatory consolidated reporting to the BDE, } \\
\text { both in solvency and accounting supervisory returns (CBE } 4 / 2004 \text {; CBE } 3 / 2008) \text {. The } \\
\text { BdE conducts onsite inspections of significant operations and reviews the reports on } \\
\text { the foreign operations and has frequent exchanges with host supervisors. Also see } \\
\text { EC } 8 \text {. }\end{array}$ \\
\hline EC8 & $\begin{array}{l}\text { The supervisor determines that oversight of a bank's foreign operations by } \\
\text { management (of the parent bank or head office and, where relevant, the holding } \\
\text { company) includes: (1) information reporting on its foreign operations that is adequate } \\
\text { in scope and frequency to manage their overall risk profile and is periodically verified; } \\
\text { (2) assessing in an appropriate manner compliance with internal controls; and } \\
\text { (3) ensuring effective local oversight of foreign operations. } \\
\text { For the purposes of consolidated risk management and supervision, there should be } \\
\text { no hindrance in host countries for the parent bank to have access to all the material } \\
\text { information from their foreign branches and subsidiaries. Transmission of such } \\
\text { information is on the understanding that the parent bank itself undertakes to maintain } \\
\text { the confidentiality of the data submitted and to make them available only to the parent } \\
\text { supervisory authority. }\end{array}$ \\
\hline
\end{tabular}




\begin{tabular}{|c|c|}
\hline & $\begin{array}{l}\text { Compliance with the detailed reporting requirements on a consolidated basis, } \\
\text { including foreign activities of banking groups (branches, subsidiaries), as laid out in } \\
\text { CBE } 4 / 2004 \text { and CBE } 3 / 2008 \text {, require in turn adequate internal reporting on foreign } \\
\text { operations. Rule } 72 \text { of CBE } 4 / 2004 \text { establishes internal accounting and management } \\
\text { control requirements. All related documentation must be at the disposal of BdE and } \\
\text { external auditors. } \\
\text { Banking groups including foreign banks must send the latter's individual audited } \\
\text { financial statements and corresponding external auditor's report to the BdE on an } \\
\text { annual basis (First Additional Provision.9 CBE } 4 / 2004 \text { ). } \\
\text { Consolidated risk management and control must comply with rule } 105 \text { CBE } 3 / 2008 \text {, } \\
\text { which includes detailed rules on group wide organizational structure, internal controls } \\
\text { (internal audit) and risk management. } \\
\text { BdE monitors the existence of adequate control by the parent bank through the regular } \\
\text { on-site work. From the bank headquarters in Spain-and through the control function } \\
\text { of the parent company-BdE frequently reviews the operations of foreign subsidiaries } \\
\text { with the focus on internal controls at the parent level. For example, the review of the } \\
\text { mortgage portfolio of a significant foreign subsidiary of a Spanish bank subsidiary } \\
\text { entailed the review of documentation sent from Mexico as well as the opinion of } \\
\text { corporate internal audit and credit risk management functions. In addition, frequent } \\
\text { video-conference meetings are held during the visits. } \\
\text { Off-site monitoring includes the solo submission by foreign subsidiaries. Also, off-site } \\
\text { supervisors hold quarterly meetings with senior management of the parent company, } \\
\text { to review the performance of foreign subsidiaries. } \\
\text { Customarily (at least yearly) top officials of foreign subsidiaries pay a visit to BdE to } \\
\text { discuss their performance and current developments in their country. } \\
\text { BdE believes that this two-layer approach: internal controls at the subsidiary level / } \\
\text { corporate controls at the parent level; solo supervision in the host country: } \\
\text { consolidated supervision by BDE sits comfortably with the responsibility of each } \\
\text { manager and of each supervisor. }\end{array}$ \\
\hline EC9 & $\begin{array}{l}\text { The home supervisor has the power to require the closing of foreign offices, or to } \\
\text { impose limitations on their activities, if: } \\
\text { - it determines that oversight by the bank and/or supervision by the host } \\
\text { supervisor is not adequate relative to the risks the office presents; and/or } \\
\text { - it cannot gain access to the information required for the exercise of supervision } \\
\text { on a consolidated basis. }\end{array}$ \\
\hline $\begin{array}{l}\text { Description and } \\
\text { findings re EC9 }\end{array}$ & $\begin{array}{l}\text { Article 30.bis.LDI, Article 13.2, } 17 \text { RD 1245/1995. BDE will deny the application to } \\
\text { open a foreign branch (non EU), or to create or buy a foreign bank by a Spanish bank } \\
\text { if it determines that foreign activities would not be subject to an effective control by } \\
\text { local authorities or that it cannot exercise an effective consolidated supervision. } \\
\text { Conditions required in the application must be met on a continuous basis. Article4.a. } \\
\text { LDI considers it a very serious infringement not to comply with the basic conditions } \\
\text { required in the authorization. }\end{array}$ \\
\hline
\end{tabular}




\begin{tabular}{|c|c|}
\hline & $\begin{array}{l}\text { Article } 174 \mathrm{RD} 1245 / 1995 \text { explicitly states that BdE can require the applicant whatever } \\
\text { additional reports, background information or data it deems necessary to assess the } \\
\text { application and, in particular, information to assist its assessment of the possibility of } \\
\text { an effective exercise of consolidated supervision. } \\
\text { BdE ensures that conditions legally required for the applicant to open a foreign branch } \\
\text { or to create/buy a foreign bank are met on a continuous basis. Otherwise, BdE would } \\
\text { make the corresponding requirements, which could include closing or limiting the } \\
\text { activities of foreign offices }\end{array}$ \\
\hline EC10 & $\begin{array}{l}\text { The supervisor confirms that oversight of a bank's foreign operations by management } \\
\text { (of the parent bank or head office and, where relevant, the holding company) is } \\
\text { particularly close when the foreign activities have a higher risk profile or when the } \\
\text { operations are conducted in jurisdictions or under supervisory regimes differing } \\
\text { fundamentally from those of the bank's home country. }\end{array}$ \\
\hline $\begin{array}{l}\text { Description and } \\
\text { findings re EC10 }\end{array}$ & $\begin{array}{l}\text { BdE has issued guidance for credit institution's policies regarding off-shore } \\
\text { establishments. In practice, these guidelines resulted in Spanish credit institutions' } \\
\text { closing the majority of such existing establishments. }\end{array}$ \\
\hline \multicolumn{2}{|l|}{$\begin{array}{l}\text { Additional } \\
\text { criteria }\end{array}$} \\
\hline AC1 & $\begin{array}{l}\text { For those countries that allow corporate ownership of banking companies: } \\
\text { - the supervisor has the power to review the activities of parent companies and of } \\
\text { companies affiliated with the parent companies, and uses the power in practice } \\
\text { to determine the safety and soundness of the bank; and } \\
\text { - the supervisor has the power to establish and enforce fit and proper standards } \\
\text { for owners and senior management of parent companies. }\end{array}$ \\
\hline & $\begin{array}{l}\text { Article 2, Article 3.c, and Article } 4 \text { RD } 1245 / 1995 \text { contain fit and proper standards for } \\
\text { significant shareholders of banks, with references to their senior management and } \\
\text { owners in the case of corporations. } \\
\text { Fit and proper assessment by BdE takes into account the transparency of the } \\
\text { structure of the group to which the credit institution would belong and, in general, } \\
\text { whether there exists obstacles to compile necessary information on the group's } \\
\text { activities (Article } 4.3 \text { RD } 1245 / 1995 \text { ). BdE also assess the chances of the credit } \\
\text { institution to be unduly exposed to the nonfinancial risks of the intended acquirer, or to } \\
\text { high financial risks deriving from the group's financial activities that may undermine its } \\
\text { safety and control (Article } 4.4 \text { RD } 1245 / 1995) \text {. } \\
\text { Such standards must be complied with on a continuous basis (Article } 2.4 \text {. RD } \\
1245 / 1995 \text { ). } \\
\text { Noncompliance is considered and infringement and is subject to the disciplinary } \\
\text { proceedings established in LDI (Chapter II and III). In particular, Article } 4.11) \text { explicitly } \\
\text { considers a very serious infringement to put at risk the safety and soundness of a } \\
\text { bank by a significant shareholder, who is subject to the LDI and to the sanctions it } \\
\text { establishes. In extreme circumstances, the Ministry of Finance, upon proposal of the } \\
\text { BdE, can revoke the bank's license (Article } 62 \text { LDI). }\end{array}$ \\
\hline AC2 & The home supervisor assesses the quality of supervision conducted in the countries in \\
\hline
\end{tabular}




\begin{tabular}{|c|c|}
\hline & which its banks have material operations. \\
\hline $\begin{array}{l}\text { Description and } \\
\text { findings re AC2 }\end{array}$ & $\begin{array}{l}\text { Article 30.bis.LDI, Article 13.2, } 17 \text { RD 1245/1995. BDE will deny the application to } \\
\text { open a foreign branch (non EU), or to create or buy a foreign bank by a Spanish bank } \\
\text { if it determines that foreign activities would not be subject to an effective control by } \\
\text { local authorities or that it cannot exercise an effective consolidated supervision. }\end{array}$ \\
\hline AC3 & $\begin{array}{l}\text { The supervisor arranges to visit the foreign locations periodically, the frequency being } \\
\text { determined by the size and risk profile of the foreign operation. The supervisor meets } \\
\text { the host supervisors during these visits. The supervisor has a policy for assessing } \\
\text { whether it needs to conduct on-site examinations of a bank's foreign operations, or } \\
\text { require additional reporting, and has the power and resources to take those steps as } \\
\text { and when appropriate. }\end{array}$ \\
\hline $\begin{array}{l}\text { Description and } \\
\text { findings re AC3 }\end{array}$ & $\begin{array}{l}\text { BdE supervises risks and controls foreign branches/subsidiaries on site from the head } \\
\text { offices/parent bank's offices. Bilateral meetings with host supervisors, participation in } \\
\text { supervisory colleges, visits and frequent contacts with local senior managers are } \\
\text { important elements of the supervision of international banks. } \\
\text { The BdE assesses whether it needs to conduct on-site examinations of a bank's } \\
\text { foreign operations or require additional reporting following its risk based model for } \\
\text { prudential supervision (see more detail in BE's website), and in collaboration with host } \\
\text { supervisors. Bilateral supervisory MoU's contain clauses regarding on-site visits to } \\
\text { foreign subsidiaries. In practice, on site visits to foreign subsidiaries or branches are } \\
\text { exceptional, taking into account: } \\
\text { - The supervision performed by host supervisors and the smooth functioning of } \\
\text { bilateral collaboration and information sharing; } \\
\text { - The relevance and robustness of information available from parent banks, } \\
\text { including internal audit reports and internal managerial information; and } \\
\text { - Regular contacts with local senior management, including meetings in Spain. }\end{array}$ \\
\hline $\begin{array}{l}\text { Assessment of } \\
\text { Principle } 24\end{array}$ & Compliant \\
\hline \multicolumn{2}{|l|}{ Comments } \\
\hline Principle 25. & $\begin{array}{l}\text { Home-host relationships. Cross-border consolidated supervision requires } \\
\text { cooperation and information exchange between home supervisors and the various } \\
\text { other supervisors involved, primarily host banking supervisors. Banking supervisors } \\
\text { must require the local operations of foreign banks to be conducted to the same } \\
\text { standards as those required of domestic institutions. }\end{array}$ \\
\hline \multicolumn{2}{|l|}{$\begin{array}{l}\text { Essential } \\
\text { criteria }\end{array}$} \\
\hline EC1 & $\begin{array}{l}\text { Information to be exchanged by home and host supervisors should be adequate for } \\
\text { their respective roles and responsibilities. }\end{array}$ \\
\hline $\begin{array}{l}\text { Description and } \\
\text { findings re EC1 }\end{array}$ & $\begin{array}{l}\text { In accordance with Article } 10 \text { bis h of Law } 13 / 1985 \text {, the BdE may develop its own } \\
\text { guidelines based on international best practices developed by international } \\
\text { supervisory standard setters. Hence, the BdE has adopted CEBS guidelines on } \\
\text { supervisory colleges. } \\
\text { Guideline 17: With a view to ensuring effective college functioning, the college } \\
\text { members should exchange all information necessary for the performance of their key }\end{array}$ \\
\hline
\end{tabular}




\begin{tabular}{|c|c|}
\hline & $\begin{array}{l}\text { activities. } \\
\text { Guideline 18: Under the coordination of the consolidating supervisor, and with due } \\
\text { regard to the CRD provisions; each member of the colleges should exchange } \\
\text { essential and relevant information for the performance of the other members' tasks. } \\
\text { In practice, this aspect is contemplated in all bilateral MoU agreed between the BdE } \\
\text { and other foreign banking supervisors. }\end{array}$ \\
\hline EC2 & $\begin{array}{l}\text { For material cross-border operations of its banks, the supervisor identifies all other } \\
\text { relevant supervisors and establishes informal or formal arrangements (such as } \\
\text { memoranda of understanding) for appropriate information sharing, on a confidential } \\
\text { basis, on the financial condition and performance of such operations in the home or } \\
\text { host country. Where formal cooperation arrangements are agreed, their existence } \\
\text { should be communicated to the banks and banking groups affected. }\end{array}$ \\
\hline $\begin{array}{l}\text { Description and } \\
\text { findings re EC2 }\end{array}$ & See EC5 of CP24. \\
\hline EC3 & 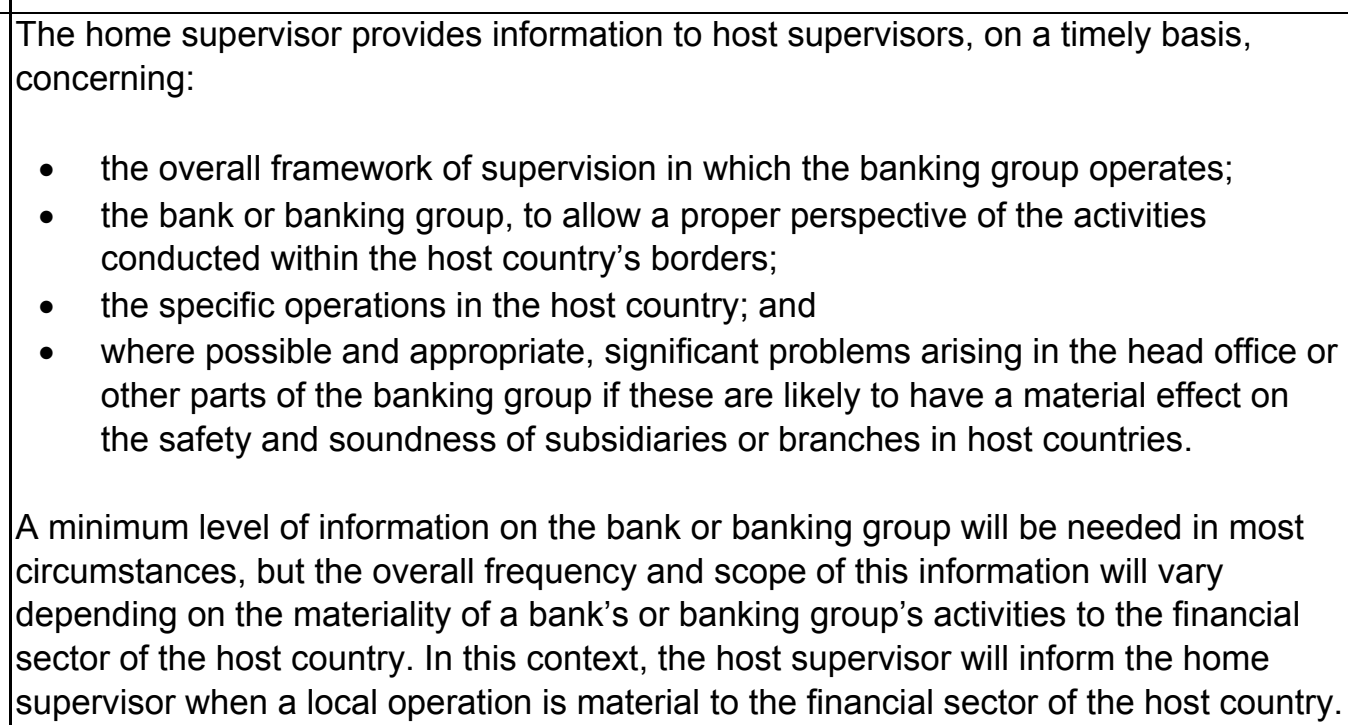 \\
\hline $\begin{array}{l}\text { Description and } \\
\text { findings re EC3 }\end{array}$ & $\begin{array}{l}\text { The BdE has extensive collaboration with host supervisors, this fact was corroborated } \\
\text { in discussions with some host supervisors. The information exchanged includes the } \\
\text { information on the Basel II models being developed and invitation to the host } \\
\text { supervisors to visit the BdE and be briefed and comment on issues that would affect } \\
\text { the local jurisdiction. Additionally, the BdE inspectors visit the host jurisdictions and } \\
\text { work with the host supervisors on the validation of the local models. } \\
\text { Other information shared/received with host supervisors includes: } \\
\text { - Information relating to planned ICAAP requests to subsidiaries (i.e., timeline and } \\
\text { content) with a view to achieving a consistent approach throughout the group; } \\
\text { - Details on the risk assessments of the supervised entities as defined under the } \\
\text { guidelines on joint risk assessment and decision on capital adequacy: relevant } \\
\text { quantitative indicators and qualitative information by risk types, main results of } \\
\text { ICAAP assessments, summary template on capital adequacy (including "scoring" } \\
\text { summarizing supervisory assessments and reasoning for any envisaged } \\
\text { additional capital requirements and/or other prudential measures taken on a } \\
\text { voluntarily basis under the joint decision process). Details cover the following }\end{array}$ \\
\hline
\end{tabular}




\begin{tabular}{|c|c|}
\hline & $\begin{array}{l}\text { areas: credit risk, concentration risk, market risk, operational risk, liquidity risk, } \\
\text { IRR in the banking book, corporate governance (including internal control), } \\
\text { business risk, overall strategy and risk appetite, results and profitability; and } \\
\text { - Views or concerns from the consolidating supervisor or the host supervisors on } \\
\text { the risk assessment and the proposed decision on the capital adequacy of the } \\
\text { group and its legal entities. } \\
\text { For the planning and coordination of supervisory activities in going concern } \\
\text { situations } \\
\text { - Methodological information relative to on-site examination, e.g., methods for } \\
\text { conducting on-site inspections, for reporting the results to the supervised } \\
\text { institutions and for following-up on the recommendations made; } \\
\text { Details on the planned supervisory activities (both on-site and off-site work, e.g., } \\
\text { key meetings) where relevant for group-wide supervision within the college. } \\
\text { Details should cover subject, level of priority and timing, rationale and objectives; } \\
\text { and } \\
\text { Main findings of supervisory activities referred to under the coordinated } \\
\text { supervisory plan agreed by the college members. }\end{array}$ \\
\hline EC4 & $\begin{array}{l}\text { The host supervisor provides information to home supervisors, on a timely basis, } \\
\text { concerning: } \\
\text { - material or persistent non-compliance with relevant supervisory requirements, } \\
\text { such as capital ratios or operational limits, specifically applied to a bank's } \\
\text { operations in the host country; } \\
\text { adverse or potentially adverse developments in the local operations of a bank or } \\
\text { banking group regulated by the home supervisor; } \\
\text { adverse assessments of such qualitative aspects of a bank's operations as risk } \\
\text { management and controls at the offices in the host country; and } \\
\text { any material remedial action it takes regarding the operations of a bank } \\
\text { regulated by the home supervisor. } \\
\text { A minimum level of information on the bank or banking group, including the overall } \\
\text { supervisory framework in which they operate, will be needed in most circumstances, } \\
\text { but the overall frequency and scope of this information will vary depending on the } \\
\text { materiality of the cross-border operations to the bank or banking group and financial } \\
\text { sector of the home country. In this context, the home supervisor will inform the host } \\
\text { supervisor when the cross-border operation is material to the bank or banking group } \\
\text { and financial sector of the home country. }\end{array}$ \\
\hline $\begin{array}{l}\text { Description and } \\
\text { findings re EC4 }\end{array}$ & See criteria 3 \\
\hline EC5 & $\begin{array}{l}\text { A host supervisor's national laws or regulations require that the cross-border } \\
\text { operations of foreign banks are subject to prudential, inspection and regulatory } \\
\text { reporting requirements similar to those for domestic banks. }\end{array}$ \\
\hline $\begin{array}{l}\text { Description and } \\
\text { findings re EC5 }\end{array}$ & $\begin{array}{l}\text { Subsidiaries established in Spain of foreign banks must be created according to } \\
\text { Spanish rules for the creation of banks, and therefore they are considered as Spanish } \\
\text { banks, so they are subject to the same prudential requirements, inspection and } \\
\text { regulatory reporting requirements as domestic banks. }\end{array}$ \\
\hline
\end{tabular}




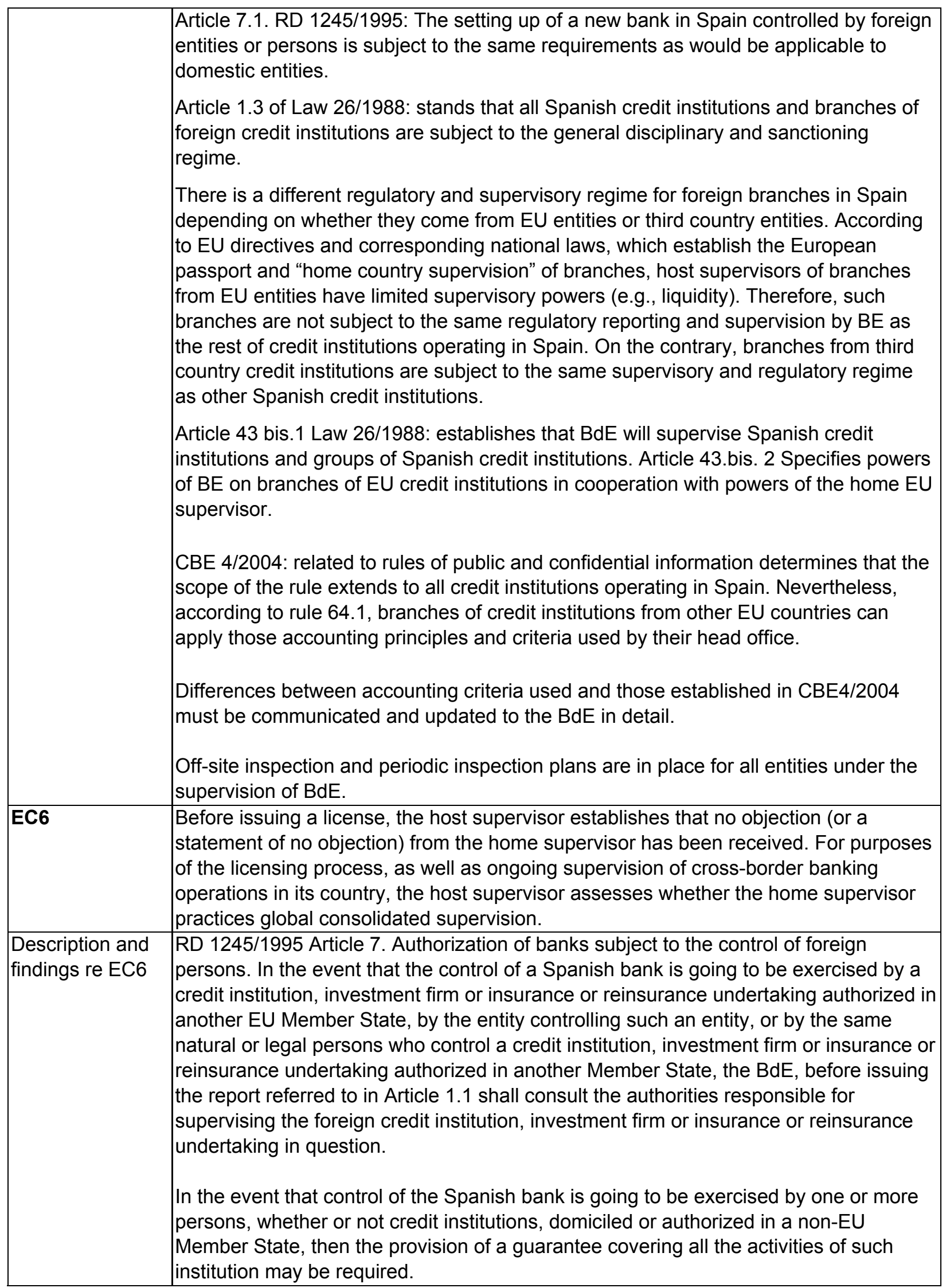




\begin{tabular}{|c|c|}
\hline & 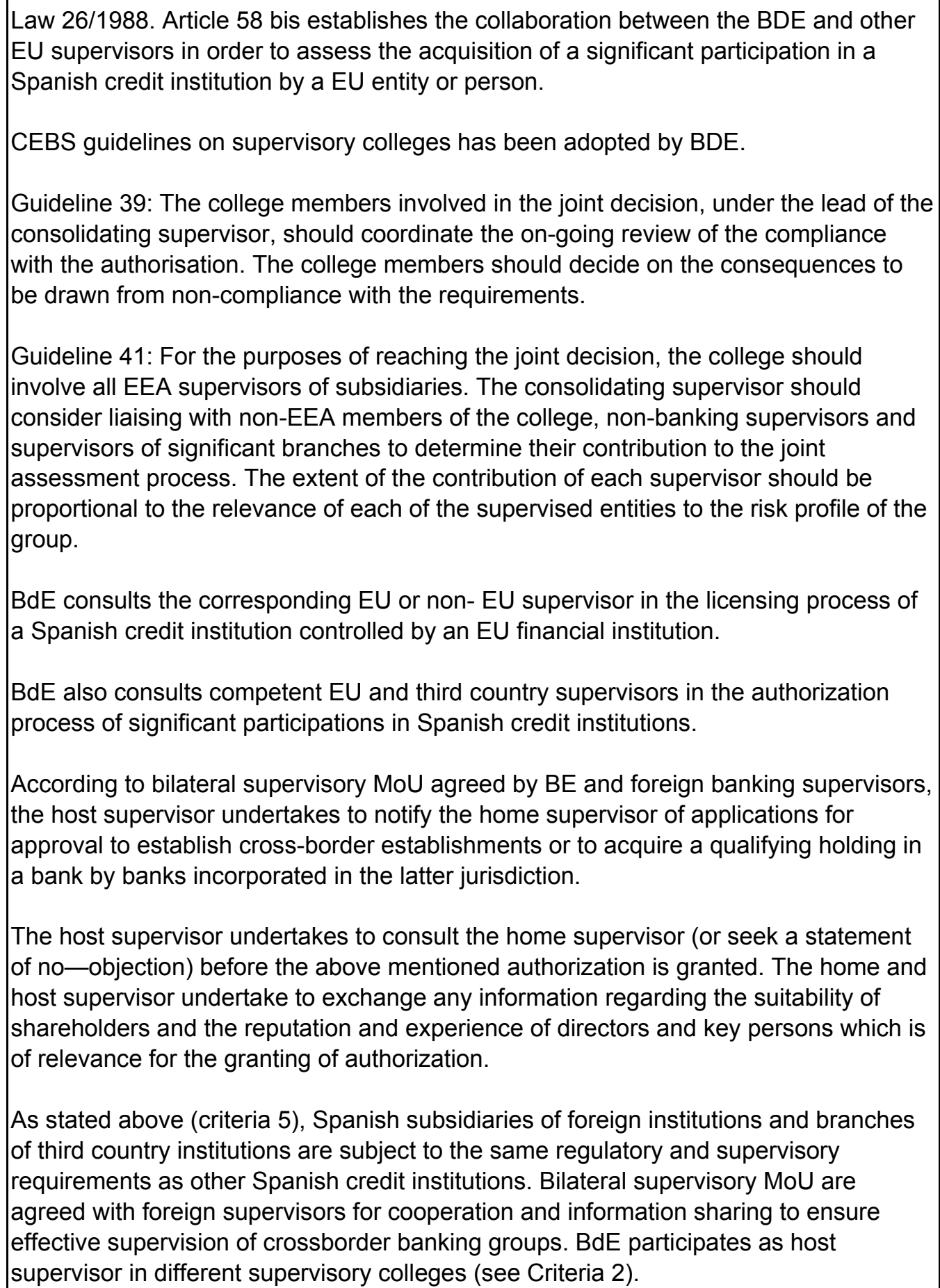 \\
\hline EC7 & $\begin{array}{l}\text { Home country supervisors are given on-site access to local offices and subsidiaries of } \\
\text { a banking group in order to facilitate their assessment of the group's safety and } \\
\text { soundness and compliance with KYC requirements. Home supervisors should inform } \\
\text { host supervisors of intended visits to local offices and subsidiaries of banking groups. }\end{array}$ \\
\hline $\begin{array}{l}\text { Description and } \\
\text { findings re EC7 }\end{array}$ & $\begin{array}{l}\text { Article 43.bis.1 Law 26/1988: BdE has inspection powers over Spanish credit } \\
\text { institutions and their groups, including all the entities of the group and all their offices } \\
\text { inside or outside the Spanish jurisdiction. BdE has powers to require the supervised } \\
\text { entities all the information needed to perform its supervisory responsibilities. Entities }\end{array}$ \\
\hline
\end{tabular}




\begin{tabular}{|c|c|}
\hline & $\begin{array}{l}\text { and persons subject to the supervision of BE are obliged to provide BE with the } \\
\text { information required, including data bases, files and computer programs. } \\
\text { This is contemplated in the bilateral MoUs, on the basis of mutual agreement on a } \\
\text { case by case basis. } \\
\text { In practice, upon previous agreement with BdE, on a case by case basis, foreign } \\
\text { home supervisors have come to do onsite inspections to Spanish subsidiaries of } \\
\text { groups under their consolidated supervision. } \\
\text { Although BdE basically performs consolidated supervision of banking groups from } \\
\text { their parent banks in Spain, where all needed information must be at BE's disposal, in } \\
\text { practice, it has on-site access as home supervisor to the foreign subsidiaries of the } \\
\text { two largest banking groups, as agreed with competent foreign supervisors on a case } \\
\text { by case basis, within the framework of agreed MoU. } \\
\text { In particular, in the field of colleges of supervisors, some joint work has been } \\
\text { achieved, especially in the validation of internal models. As a consolidated supervisor } \\
\text { the BdE has had access to the subsidiaries offices in other countries. }\end{array}$ \\
\hline EC8 & $\begin{array}{l}\text { The host supervisor supervises shell banks, where they still exist, and booking offices } \\
\text { in a manner consistent with internationally agreed standards. }\end{array}$ \\
\hline $\begin{array}{l}\text { Description and } \\
\text { findings re EC8 }\end{array}$ & $\begin{array}{l}\text { Not applicable due to the fact that in Spain there are no shell branches. In } 2001 \mathrm{BdE} \\
\text { published in the Banking Supervision Report some principles and criteria related to } \\
\text { activities off-shore. }\end{array}$ \\
\hline EC9 & $\begin{array}{l}\text { A supervisor that takes consequential action on the basis of information received from } \\
\text { another supervisor consults with that supervisor, to the extent possible, before taking } \\
\text { such action. }\end{array}$ \\
\hline $\begin{array}{l}\text { Description and } \\
\text { findings re EC9 }\end{array}$ & $\begin{array}{l}\text { Before taking any supervisory action, BdE makes sure the information on which it is } \\
\text { based is reliable. BdE has full access to information regarding entities subject to its } \\
\text { supervision, irrespective whether it is referred to offices in Spain or abroad (See EC7). } \\
\text { Additionally, BdE maintains open communications with other foreign supervisors from } \\
\text { jurisdictions where Spanish banking groups have relevant presence or vice-versa (see } \\
\text { information above on bilateral MoU and colleges of supervisors). Such information } \\
\text { sharing does not affect each supervisor's responsibilities and liabilities as established } \\
\text { in their respective regulations. }\end{array}$ \\
\hline \multicolumn{2}{|l|}{$\begin{array}{l}\text { Additional } \\
\text { criteria }\end{array}$} \\
\hline AC1 & $\begin{array}{l}\text { Where necessary, the home supervisor develops an agreed communication strategy } \\
\text { with the relevant host supervisors. The scope and nature of the strategy should reflect } \\
\text { the size and complexity of the cross-border operations of the bank or banking group. }\end{array}$ \\
\hline $\begin{array}{l}\text { Description and } \\
\text { findings re AC1 }\end{array}$ & $\begin{array}{l}\text { Article 10.quarter Law 13/1985: related to the establishment of colleges of supervisors. } \\
\text { It complies with Directive } 2009 / 111 / \text { CE which has been transposed into the Spanish } \\
\text { regulation through Law } 6 / 2011 \text { and therefore modifies law } 13 / 1985 \text {. In addition to } \\
\text { addressing issues such as information exchanges it addresses other tasks such as for } \\
\text { example a joint risk assessment and the validation of internal models. } \\
\text { Guideline 19: When coordinating information flows within the college and between its } \\
\text { different settings, the consolidating supervisor should take due account of the nature } \\
\text { of supervised entities, their relevance within the group and significance in their local } \\
\text { markets, as well as confidentiality provisions }\end{array}$ \\
\hline
\end{tabular}


See references above on supervisory colleges.

BdE has recently developed a website for the exclusive use of host supervisors to obtain and share information.

\begin{tabular}{|l|l} 
Assessment of & Compliant
\end{tabular}

Principle 25

Comments 